\title{
Os registros de acidentes do trabalho no meio rural paulista: as culturas sucroalcooleira e de frutas cítricas entre 1997 e 1999
}

\author{
Rosa Maria Vieira de Freitas
}

Dissertação apresentada ao Programa de PósGraduação em Saúde Pública da Faculdade de Saúde Pública da Universidade de São Paulo para obtenção do título de Mestre em Saúde Pública.

Área de Concentração: Saúde Ambiental Orientadora: Profa. Dra. Ana Isabel B. B. Paraguay

São Paulo 2005 
Autorizo, exclusivamente para fins acadêmicos e científicos, a reprodução total ou parcial desta dissertação, por processos fotocopiadores.

Assinatura:

Data: 
A minha família, meus pais José e Bela, minhas irmãs Guida e Paula, meu cunhado Gerson e sobrinhos Filipe e Pedro, pelo carinho, incentivo e paciência. 


\section{AGRADECIMENTOS}

A Profa. Ana Isabel Bruzzi Bezerra Paraguay, pela orientação rigorosa e sempre presente.

Aos membros da banca examinadora de qualificação e de defesa, Profs. Drs. Heleno Rodrigues Corrêa Filho, Frida Marina Fischer, Thomas Dwyer, Ildeberto Muniz de Almeida, Sabina Léa Davidson Gotlieb e Celso Amorim Salim, pela leitura detalhada e pelos valiosos comentários.

Aos colegas de orientação Jenny Izumi Kose, Rodrigo Manoel Giovanetti, pela troca de experiências e sugestões.

À Fundação Seade e a Fundacentro pela liberação da base de dados sobre acidentes do trabalho que foi a principal fonte de análise dessa pesquisa.

A Diretoria da Fundação Seade, a Bernadette Waldvogel e Cecília Polidoro Mameri, pelo apoio institucional e incentivo.

Aos meus amigos, Antonio Benedito Marangone Camargo, Antonio Etevaldo Teixeira Jr., Elizabeth Fuzisaki, Fábio Rampazzo Mathias, Lilian Cristina Correia de Morais, Luciane Lestido Castiñeiras, Luis Patrício Ortiz Flores, Magaly de Losso Perdigão, Magali Valente, Monica La Porte Teixeira, Valmir José Aranha, pelas discussões e pela inestimável ajuda prestada durante a elaboração dessa dissertação.

Aos meus amigos que muito me incentivaram, Ana Cristina Vieira de Freitas, Ana Lucia Siqueira, Ângela Lenzi Azzi Ferreira, Antonio Carlos Caldeira, Carlos Eugenio de Carvalho Ferreira, Deise Akiko Oushiro, João Francisco Resende, Lucia Yazaki, Marcelo Gonçalves Rodrigues, Marcia Cifuentes, Maria Aparecida Teixeira, Maria da Graça, Marli Ramos da Costa, Miriam Emidia de Oliveira, Paulo Borlina Maia, Rosana Capassi, Rosangela Montenegro, Rute Godinho, Samara Aparecida Porto, Sonia Regina Perillo e Quitéria Domingos da Silva. 
A toda minha família e a todos que com seu carinho tiveram sempre uma palavra amiga nos momentos difíceis, contribuindo dessa forma para a realização desse trabalho. 


\section{RESUMO}

Freitas RMV. Os registros de acidentes do trabalho no meio rural paulista: as culturas sucroalcooleira e de frutas cítricas entre 1997 e 1999. São Paulo; 2005. [Dissertação de Mestrado - Faculdade de Saúde Pública da USP].

Objetivo. Este é um estudo descritivo de corte transversal com calculo anual das taxas de incidência acumulada, mortalidade e letalidade para os registros de Acidentes do Trabalho-AT ocorridos no meio rural, entre 1997 e 1999 no Estado de São Paulo, que enfocou as categorias profissionais envolvidas nas culturas sucroalcooleiras e cítricas. Métodos. Elaborou-se uma base de dados, a partir de uma pesquisa realizada pela Fundação Seade/Fundacentro, com informações sobre registros de AT, notificados nas agências da Previdência Social do Estado de São Paulo através da CAT. Resultados. Dos 57.867 acidentes do trabalho registrados em áreas rurais entre 1997 e 1999, 43\% eram de trabalhadores da cultura sucroalcooleira e $4 \%$ da cultura cítrica. Neste período, observou-se um crescimento relevante entre os registros de acidentes do trabalho da cultura cítrica, de cerca de $44 \%$. Enquanto, a cultura sucroalcooleira apresentou as mais elevadas taxas de incidência acumulada calculada para a população trabalhadora residente no Estado de São Paulo e contribuinte de Instituto de Previdência Oficial. A distribuição geográfica estadual paulista indicou que as áreas que apresentaram as maiores incidências acumuladas foram aquelas próximas a municípios onde se concentram grandes centros agroindustriais, principalmente, os de frutas cítricas e os de cana-de-açúcar, locais estes onde o trabalho formal esta instituído.Conclusões. Apesar de compreender somente os trabalhadores assegurados, a CAT constitui importante material de análise, fornecendo subsídios para o entendimento da questão acidentária. No meio rural, os acidentes do trabalho são um grave problema de saúde publica, assim como, nas culturas sucroalcooleiras e cítricas.

Descritores: Acidentes do Trabalho. Acidente Rural. Cana-de-açúcar. Laranja. Sucroalcooleira. Frutas Cítricas. 


\section{SUMMARY}

Freitas RMV. Records of work-related accidents in the rural area of the state of São Paulo: citrus fruit and sugarcane crops from 1997 to 1999: São Paulo; 2005. [Masters Degree Dissertation - Faculdade de Saúde Pública (Public Health College) of USP (University of São Paulo)].

Purpose. This is a cross-sectional descriptive study with annual calculation of the accumulated incidence, mortality and deadliness rates recorded concerning WorkRelated Accidents (WRT) in the rural area of the state of São Paulo from 1997 to 1999, focused on workers involved in citrus and sugarcane crops. Methods. A study conducted by the Fundação Seade/Fundacentro, with information about records of WRT reported to the São Paulo State Social Security agencies through CAT, was the basis for a database. Results. Of the $\mathbf{5 7 . 8 6 7}$ work-related accidents recorded in rural areas from 1997 to 1999, 43\% involved sugarcane crops and 4\% citrus crops. During this period significant growth of $44 \%$ was registered in the citrus crops workrelated accident records, while sugarcane crops related-accidents turned in the highest rates of accumulated incidence for the working population in the state of São Paulo officially registered in the Social Security. The São Paulo State geographical distribution indicated that the areas which reported the highest accumulated incidence were those located near municipalities which have large agribusiness centers, especially in citrus fruit and sugarcane, and where workers have been formally registered. Conclusions. Although only state insured workers are included, CAT constitutes important analysis material and provides grounds for understanding the accident rate issue. In rural areas, work-related accidents pose a serious public health problem as well as in sugarcane and citrus crops.

Key Words: Work-Related Accidents. Rural Accident.Sugarcane. Orange. Sugarcane Industry. Citrus Fruit. Rural Workers. 


\section{ÍNDICE}

1 INTRODUÇÃO.

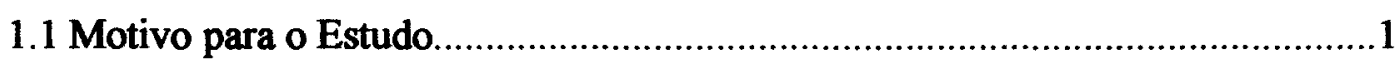

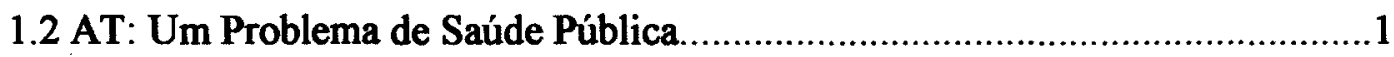

1.3 Definição e Conceito Juridico .............................................................................

1.4 Comunicação de Acidente do Trabalho - CAT: Fonte de Informação.................8

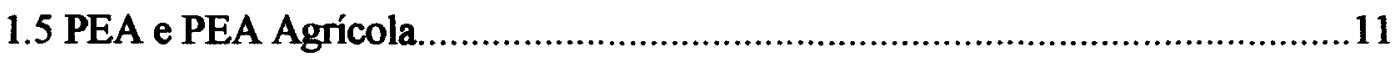

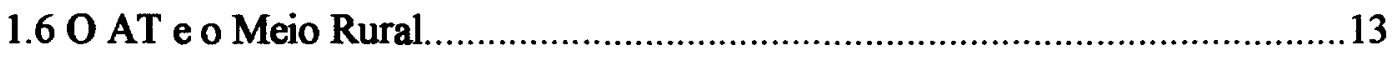

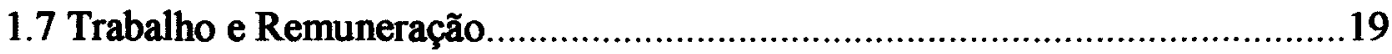

1.8 Processos de Produção e de Trabalho no Meio Rural..........................................22

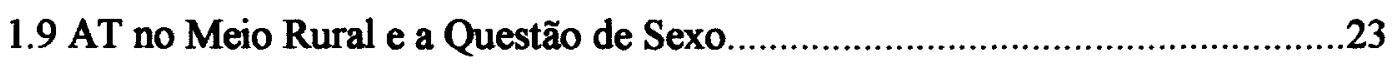

1.10 Processo de Produção nas Culturas da Cana-de-açúcar e das Frutas Cítricas

1.11 Processo de Trabalho nas Culturas da Cana-de-açúcar e das Frutas

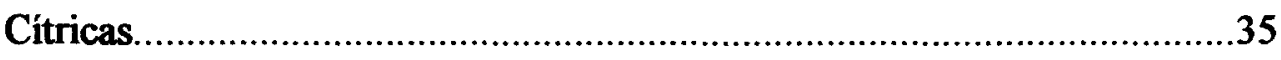

2 OBJETIVOS

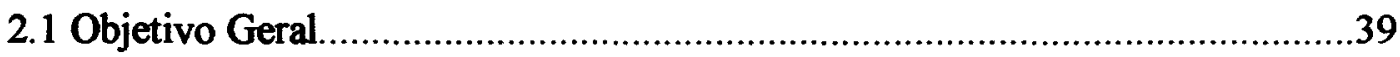

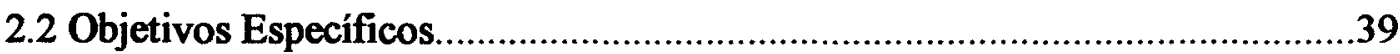

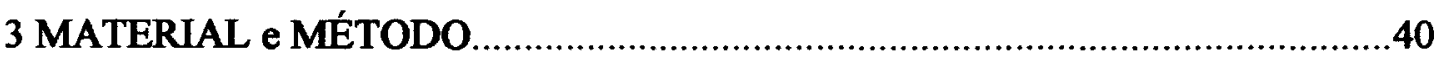

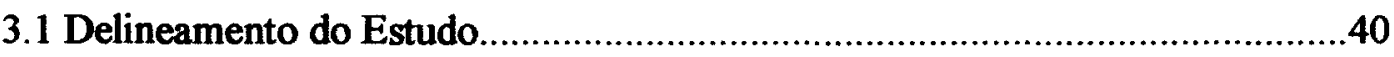

3.2 Universo de Estudo.....................................................................................

3.3 Período de Referência

3.4 Abrangência Geográfica do Estudo.................................................................

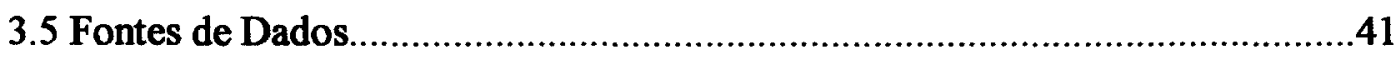


3.5.1 Principal Fonte de Informação.

3.5.2 Outras Fontes Utilizadas.

3.6 Configuração do Banco de Dados Seade/Fundacentro

3.6.1 Consolidação dos Dados da Pesquisa da Fundação Seade/Fundacentro....47

3.7 Configuração do Banco de Dados Especifico dessa Pesquisa.

3.7.1 Elaboração das Sub-bases Estudadas. .48

3.7.2 Consolidação do Banco de Dados Especifico dessa Pesquisa. .48

3.8 Elaboração dos Denominadores. .49

3.9 Tratamento e Análise dos Dados. .53

3.9.1 Variáveis selecionadas para a realização das Freqüências. . .53

3.9.2 Elaboração das Freqüências segundo as Variáveis Selecionadas. 56

3.9.3 Cálculo dos Indicadores. .56

4 RESULTADOS .61

4.1 Consolidação do Banco de Dados Específico dessa Pesquisa. .61

4.2 Descrição das Variáveis. .62

4.2.1 Distribuição dos Registros de AT por Tipo de Acidente. 62

4.2.2 Distribuição dos Registros de AT segundo a Conseqüência do Acidente..64

4.2.3 Distribuição dos Registros de AT das Culturas Sucroalcooleira e Cítrica segundo Tipo e Conseqüência. .65

4.2.4 Distribuição dos Registros de AT segundo o Sexo do Acidentado.

4.2.5 Distribuição dos registros de AT das Culturas Sucroalcooleira e Cítrica segundo Tipo e Sexo. .68

4.2.6 Distribuição dos Registros de AT por Faixa Etária dos Acidentados. 69

4.2.7 Distribuição dos Registros de AT segundo Menores de 18 Anos. .72 
4.2.8 Distribuição da Ocupação do Trabalhador nas Culturas Sucroalcooleira e Cítricas. 74

4.2.9 Distribuição dos Registros de Acidente do Trabalho segundo as Partes do Corpo Atingidas. 76

4.3 Estimativa das Taxas de Incidência Acumulada, Mortalidade e Letalidade.....89

4.3.1 Área Rural .89

4.3.2 Cultura Sucroalcooleira 100

4.3.3 Cultura de Frutas Cítricas 105

5 DISCUSSÃO. 110

5.1 Tipo de Estudo 110

5.2 Fonte de Análise. 110

5.3 Vantagens e Desvantagens da Utilização do Banco Seade/Fundacentro 113

5.4 Vantagens e Desvantagens do Banco Utilizado nessa Pesquisa 114

5.5 Variáveis de Estudo. 115

5.5.1 Distribuição dos Registros e AT segundo o Tipo de Acidente. 115

5.5.2 Distribuição dos Registros de AT segundo a Conseqüência do Acidente .117

5.5.3 Distribuição dos Registros de AT das Culturas Sucroalcooleira e das Frutas Cítricas segundo Tipo e Conseqüência. 118

5.5.4 Distribuição dos Registros de AT segundo o Sexo do Acidentado. 119

5.5.5 Distribuição dos Registros de AT das Culturas Sucroalcooleira e de Frutas Cítricas segundo Tipo e Sexo 121

5.5.6 Distribuição dos Registros de AT segundo Faixa Etária. 122 
5.5.8 Distribuição da Ocupação do Trabalhador nas Culturas Sucroalcooleira e das Frutas Cítricas.

5.5.9 Distribuição dos Registros de AT segundo as Partes do Corpo Atingidas.

5.6 Descrição dos AT e das Doenças do Trabalho. 128

5.7 Indicadores de Índice de Freqüência, Índice de Gravidade e Índice de Custo 130

5.8 Estimativa da Incidência Acumulada, Mortalidade e Letalidade 131

6 CONCLUSÕES 137

7 CONSIDERAÇÕES FINAIS. 142

8 REFERÊNCIAS 145

ANEXOS

ANEXO 1 - Modelo do Formulário de Coleta. A-1

ANEXO 2 - Agências da Previdência Social do Estado de São Paulo A-2

ANEXO 3 - Classificação da Variável Descrição dos Acidentes e das Doenças do Trabalho. A-3

ANEXO 4 - Áreas Elaboradas do Estado de São Paulo para o Meio Rural. 1997, 19981999 A-13

ANEXO 5 - Áreas Elaboradas do Estado de São Paulo para a Cultura Sucroalcooleira. 1997, 1998 e 1999. A-20

ANEXO 6 - Áreas Elaboradas do Estado de São Paulo para a Cultura Frutas Cítricas. 1997, 1998 e 1999

ANEXO 7 - Parecer da Comissão de Ética em Pesquisa da FSP

ANEXO 8 - Termo de Concordância 
ANEXO 9 - Termo de Compromisso de Uso 


\section{LISTA DE FIGURAS}

Figura 1 - Número de Acidentes do Trabalho Registrados. Brasil e Estado de São Paulo, $1998-2002$ 4

Figura 2 - Produtos de Lavoura Temporária e Permanente, por Área Colhida (Hectare). Mesorregiōes Geográficas do Estado de São Paulo, $1995 / 1996$ 30

Figura 3 - Proporção de Registros de AT em Área Rural, segundo Ano da Ocorrência e Grupos de Idade. Estado de São Paulo, 1997, 1998 e 1999. 70

Figura 4 - Proporção de Registros de AT em Cultura Sucroalcooleira, segundo Ano da Ocorrência e Grupos de Idade. Estado de São Paulo, 1997, 1998 e 1999. .71

Figura 5 - Proporção de Registros de AT em Cultura de Frutas Cítricas, segundo Ano da Ocorrência e Grupos de Idade. Estado de São Paulo. 1997, 1998 e 1999. 72

Figura 6 - Proporção de Registros de AT de Menores de 18 Anos em Áreas Rurais, por Ano do Acidente e Tipo de Cultura. Estado de São Paulo. 1997, 1998 e 1999 .73

Figura 7 - Taxa de Incidência Acumula dados Registros de Acidentes do Trabalho em Áreas Rurais. Municípios do Estado de São Paulo Agrupados em Áreas Elaboradas, 1997 92 
Figura 8 - Taxa de Incidência Acumulada dos Registros de Acidentes do Trabalho em Áreas Rurais. Municípios do Estado de São Paulo.Agrupados em Áreas Elaboradas, 1998 93

Figura 9 - Taxa de Incidência Acumulada dos Registros de Acidentes do Trabalho em Áreas Rurais. Municípios do Estado de São Paulo. Agrupados em Áreas Elaboradas, 1999. .94

Figura 10 - Taxa de Incidência Acumulada dos Registros de Acidentes do Trabalho na Cultura Sucroalcooleira. Municípios do Estado de São Paulo. Agrupados em Áreas Elaboradas, 1997, 1998 e 1999. .104

Figura 11 - Taxa de Incidência Acumulada dos Registros de Acidentes do Trabalho na Cultura de Frutas Cítricas. Municípios do Estado de São Paulo. Agrupados em Áreas Elaboradas, 1997, 1998 e 1999 109 


\section{LISTA DE TABELAS}

Tabela 1 - População com 10 Anos e Mais de Idade, Ocupada, segundo Setores de

Atividade Econômica. Brasil e Estado de São Paulo, 1970/1999. .12

Tabela 2 - Número e Proporção dos Registros de AT em Áreas Rurais, nas Culturas Sucroalcooleira e das Frutas Cítricas, segundo Ano e Tipo do AT. Estado de São Paulo, 1997, 1998 e 1999. .63

Tabela 3 - Número e Proporção dos Registros de AT em Áreas Rurais, nas Culturas Sucroalcooleira e das Frutas Cítricas, segundo Ano e Conseqüência do AT. Estado de São Paulo, 1997, 1998 e 1999 .64

Tabela 4 - Número e Proporção dos Registros de AT nas Culturas Sucroalcooleira e das Frutas Cítricas, por Tipo de AT e Conseqüência do Acidente. Estado de São Paulo. 1997, 1998 e 1999. .66

Tabela 5 - Número e Proporção dos Registros de AT em Áreas Rurais, nas Culturas Sucroalcooleira e das Frutas Cítricas, segundo Ano do Acidente e Sexo do Acidentado. Estado de São Paulo. 1997, 1998 e 1999.

Tabela 6 - Número e Proporção dos Registros de AT nas Culturas Sucroalcooleira e das Frutas Cítricas, por Sexo e Tipo de Acidente. Estado de São Paulo. 1997,1998 e 1999.

Tabela 7 - Número e Proporção dos Registros de AT na Cultura Sucroalcooleira, por Ocupação do Trabalhador. Estado de São Paulo. 1997, 1998 e 1999. 
Tabela 8 - Número e Proporção dos Registros de AT na Cultura das Frutas Cítricas, por Ocupação do Trabalhador. Estado de São Paulo. 1997, 1998 e 1999

Tabela 9 - Distribuição do Número e Proporção dos Registros de Acidentes do Trabalho em Áreas Rurais por Sexo, segundo Tipo e principais Partes do Corpo Atingidas no Acidente. Estado de São Paulo. 1997.

Tabela 10 - Distribuição do Número e Proporção dos Registros de Acidentes do Trabalho em Áreas Rurais por Sexo, segundo Tipo e principais Partes do Corpo Atingidas no Acidente. Estado de São Paulo. 1998. . .78

Tabela 11 - Distribuição do Número e Proporção dos Registros de Acidentes do Trabalho em Áreas Rurais por Sexo, segundo Tipo e principais Partes do Corpo Atingidas no Acidente. Estado de São Paulo. 1999. 79

Tabela 12 - Distribuição do Número e Proporção dos Registros de Acidentes do Trabalho da Cultura Sucroalcooleira por Sexo, segundo Tipo e principais Partes do Corpo Atingidas no Acidente. Estado de São Paulo. 1997. 81

Tabela 13 - Distribuição do Número e Proporção dos Registros de Acidentes do Trabalho da Cultura Sucroalcooleira por Sexo, segundo Tipo e principais Partes do Corpo Atingidas no Acidente. Estado de São Paulo. 1998. 82

Tabela 14 - Distribuição do Número e Proporção dos Registros de Acidentes do Trabalho daCultura Sucroalcooleira por Sexo, segundo Tipo e principais 
Partes do Corpo Atingidas no Acidente. Estado de São Paulo. 1999 .83

Tabela 15 - Distribuição do Número e Proporção dos Registros de Acidentes do Trabalho da Cultura de Frutas Cítricas por Sexo, segundo Tipo e principais Partes do Corpo Atingidas no Acidente. Estado de São Paulo. 1997. .85

Tabela 16 - Distribuição do Número e Proporção dos Registros de Acidentes do Trabalho da Cultura de Frutas Cítricas por Sexo, segundo Tipo e principais Partes do Corpo Atingidas no Acidente. Estado de São Paulo. 1998. .86

Tabela 17 - Distribuição do Número e Proporção dos Registros de Acidentes do Trabalho da Cultura de Frutas Cítricas por Sexo, segundo Tipo e principais Partes do Corpo Atingidas no Acidente. Estado de São Paulo. 1999 .87

Tabela 18 - Taxa de Incidência Acumulada dos Registros de Acidentes do Trabalho de Áreas Rurais. Estado de São Paulo. 1997, 1998 e 1999 .91

Tabela 19 - Taxa de Mortalidade dos Registros de Acidentes do Trabalho de Áreas Rurais. Estado de São Paulo. 1997, 1998 e 1999 97

Tabela 20 - Taxa de Letalidade dos Registros de Acidentes do Trabalho de Áreas $\begin{array}{lllllll}\text { Rurais. Estado de São Paulo. 1997, } 1998 & \text { e }\end{array}$ 1999 .99 
Tabela 21 - Taxa de Incidência Acumulada dos Registros de Acidentes do Trabalho nas Culturas Sucroalcooleiras, segundo as Áreas Elaboradas do Estado de São Paulo. 1997, 1998 e 1999 101

Tabela 22 - Taxa de Mortalidade dos Registros de Acidentes do Trabalho na Cultura Sucroalcooleira segundo as Áreas Elaboradas do Estado de São Paulo. 1997,1998 e 1999. 102

Tabela 23 - Taxa de Letalidade dos Registros de Acidentes do Trabalho na Cultura Sucroalcooleira, segundo as Áreas Elaboradas do Estado de São Paulo. 1997,1998 e 1999 103

Tabela 24 - Taxa de Incidência Acumulada dos Registros de Acidentes do Trabalho na Cultura de Frutas Cítricas, segundo as Áreas Elaboradas do Estado de São Paulo. 1997, 1998 e 1999 106

Tabela 25 - Taxa de Mortalidade dos Registros de Acidentes do Trabalho na Cultura de Frutas Cítricas, segundo as Áreas Elaboradas do Estado de São Paulo. 1997, 1998 e 1999 107

Tabela 26 - Taxa de Letalidade dos Registros de Acidentes do Trabalho na Cultura de Frutas Cítricas, segundo as Áreas Elaboradas do Estado de São Paulo. 1997,1998 e 1999. 108 


\section{INTRODUÇÃO}

\subsection{Motivo para o estudo}

A autora trabalhou, entre outubro de 2000 e maio de 2001, no levantamento de dados estatísticos junto a Previdência Social do Estado de São Paulo. Neste periodo, percorreu cerca de 20 municípios do interior paulista (Região Centro-Oeste, Oeste e Litoral), coletando informações referentes aos registros de Acidente do Trabalho (doravante designado como AT), quando se deparou com uma realidade muito distinta e dificil, vivenciada por estes trabalhadores rurais.

Quando esteve em Jaú, município situado na região Centro-Oeste do Estado, conhecida pela cultura de cana-de-açúcar, teve a oportunidade de observar 0 comportamento de trabalhadores rurais. Certa tarde, no centro da cidade, deparou-se com uma cortadora de cana com uma postura muito cabisbaixa. Muito tímida e de andar acelerado, parecia alheia à sua condição de cidadã.

Olhando aquela trabalhadora, reflexões surgiram sobre o cotidiano laboral e as inúmeras dificuldades enfrentadas, diariamente, por esses trabalhadores.

Instigada pelo encontro com a trabalhadora, houve a oportunidade de entender melhor aquela realidade díspare e, com a oportunidade de analisar o banco de dados coletados sobre os registros de AT, iniciou-se esse trabalho de pesquisa.

\subsection{AT: um problema de saúde pública}

Os trabalhadores, no exercício diário de suas atividades trabalhistas, estão sujeitos aos mais distintos infortúnios, entre estes, encontram-se os acidentes do trabalho (LACAZ 1997) que, no Brasil, são considerados como o principal evento mórbido entre a classe trabalhadora (WÜNSCH FILHO 1999). 
Comum a todas as categorias profissionais, presente em todos os paises e observado nos mais distintos períodos históricos, o AT faz parte do cotidiano da classe trabalhadora, classificando-se como um sério problema de saúde pública mundial (OIT 2003).

Dados divulgados pela Organização Internacional do Trabalho - OIT reafirmam esse grave panorama. Segundo esta Instituição, ocorrem 270 milhões de acidentes por ano no mundo, sendo 350 mil fatais (OIT 2004a). Ou seja, a cada dia e em média 959 trabalhadores perdem a vida no exercício de suas atividades profissionais.

O binômio saúde/doença no ambiente do trabalhado é uma questão que atinge não só o trabalhador e seus familiares, mas a economia, a política e a saúde de um país, constituindo-se num sério problema de saúde pública.

Por valer-se, até 1889 , da força de trabalho escravo e apresentar uma industrialização tardia, o Brasil só veio a estudar e se preocupar com a tríade trabalho/saúde/doença no final do século XIX e início do século XX (CORTEZ 2001).

Entretanto, como campo de práticas e conhecimentos, o movimento sobre saúde do trabalhador surge com a consolidação do operariado industrial urbano nos países da América Latina e no Brasil (LACAZ 1997).

Foram as greves da década de 1910, principalmente a ocorrida em 1917, deflagrada em São Paulo, que iniciaram a luta dos trabalhadores por melhores condições de trabalho. Visavam, entre outros fatores, abolir a exploração do trabalho dos menores de 14 anos nas fábricas, oficinas e outros, o fim dos trabalhos noturnos para os menores de 18 anos; bem como, a revogação do trabalho noturno feminino e a padronização da jornada de oito horas. Nessa época, os trabalhadores enfrentavam péssimas condições de trabalho e cumpriam extenuantes jornadas diárias, não 
havendo, então, nenhum respaldo legal aos seus direitos (PENA et al 2003). Nesse periodo, o movimento sindical atuava buscando a redução da jornada de trabalho e diminuição dos ATs (MTE 2004).

Com o objetivo de melhorar as condições de saúde e trabalho no Brasil, a partir da década de 1930, várias leis sociais são criadas, dentre elas, ressalta-se: a obrigatoriedade da formação da Comissão Interna de Prevenção de Acidentes CIPA, criada oficialmente em 1944 (Decreto lei $n^{\circ} 7036$ de 10/11/44). Mas é, somente, na década de 1970, que a luta pela saúde no trabalho alcança posição privilegiada (COSTA 2002). É nessa década, que o Brasil apresentava, segundo POSSAS (1987), uma das mais elevadas taxas de AT do mundo, chegando a conquistar o título de campeão mundial de AT (CORTEZ 2001).

Nos anos 80 , séc. XX, com a redemocratização do País, o movimento social dos trabalhadores retorna à cena política, estabelecendo uma outra relação entre Estado e Sociedade (LACAZ 1997). Nessa década e na posterior, ocorre um decréscimo no número de acidentes de trabalho registrados na Previdência Social. Essa tendência de queda se observa, praticamente, durante todo o período da década de 1990 até 2002 (Figura 1). Segundo WÜNSCH FILHO (1999), a evolução dos dados de AT seria justificada também pelas mudanças econômicas ocorridas no País, tais como o aumento do trabalho informal e a migração da mão-de-obra para setores com menor risco de acidentes.

Apesar de se referir apenas aos acidentes registrados oficialmente, não incluindo a parcela populacional não contribuinte da Previdência Social, os dados sobre AT são preocupantes (RIBEIRO 2000). Em 2002, foram registrados 387.905 acidentes no País e 152.145 no Estado de São Paulo (PREVIDÊNCIA SOCIAL 2002). O que correspondeu, apesar do sub-registro, a um aumento de $14 \% \mathrm{em}$ relação ao ano anterior, tanto para o Brasil, como para o Estado de São Paulo (Figura 1). 
Figura 1

Número de Acidentes do Trabalho Registrados

Brasil e Estado de São Paulo

Ne Acidentes

1988 - 2002

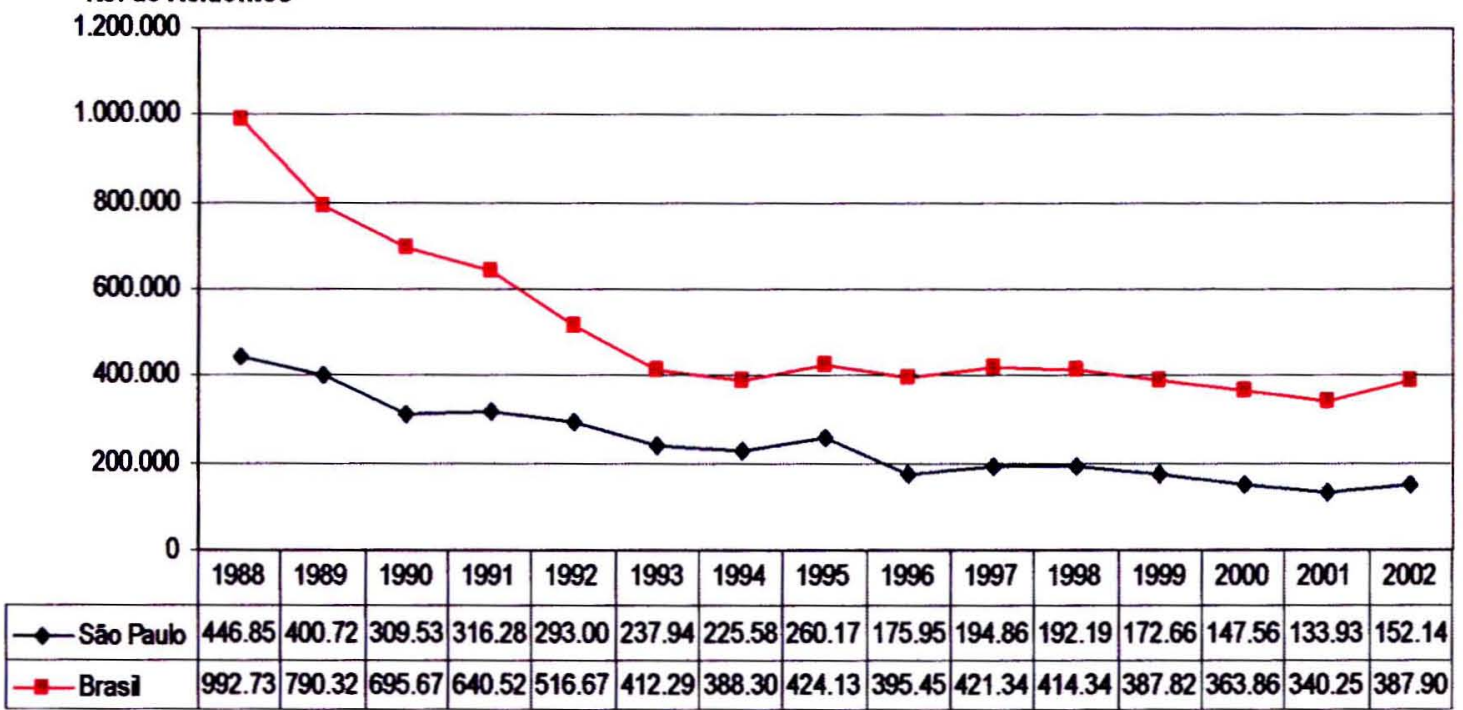

Fonte: Previdência Social- DataPrev.

Diante de sua importância e da magnitude dos seus prejuízos, o AT, constituise em um grave problema de saúde pública no País, sendo foco de atenção de vários estudos (LUCCA e FÁVERO 1994) e um dos principais indicadores da relação saúde/doença no trabalho (WÜNSCH FILHO 1999).

\subsection{Definição e conceito jurídico}

Agravo que pode causar sérios danos físicos ou psíquicos ao trabalhador (CÔRREA FILHO 1994a), sendo o mais grave sua morte (WALDVOGEL 2001), o AT se caracteriza como categoria social e econômica e, como tal, está estritamente ligado ao modo de produção e às relações sociais (LERT et al 1984).

Uma vez que as relações sociais são decorrentes do modo de produção de cada época e sociedade, a ocorrência dos ATs encontra-se intimamente ligada ao processo de trabalho, ou seja, às condições de trabalho existentes, já que cada 
processo de trabalho apresenta uma "tipologia própria e uma gravidade intrínseca" (MACHADO e GOMEZ 1994, p.83).

O AT suscita diversas explanações. DWYER (1994) propõe um modelo de explicação, baseado na teoria da sociologia do trabalho, segundo a qual, os acidentes na indústria resultariam das relações sociais do trabalho ${ }^{1}$ existentes na sociedade. Onde, estes estariam intimamente ligados ao estado de funcionamento das relações sociais nos niveis organizacionais de comando e de recompensa e, também, a influência não social que seria o indivíduo membro (DWYER 1994; DWYER e RAFTERY 1991).

O nível organizacional está relacionado ao controle do empregado sobre a divisão do trabalho. A monotonia e os aborrecimentos, associados ao desempenho da rotina do trabalho, são considerados os responsáveis pela produção dos acidentes. Esse nivel seria o responsável pela maioria dos ATs na área industrial nas nações mais desenvolvidas.

Com menor relevância na geração dos acidentes (DWYER e RAFTERY 1991), o nível de comando está relacionado ao uso do autoritarismo. Neste nível, a integração do trabalho de grupo poderia levar a uma redução dos acidentes.

No nível de recompensa, fatores como incentivos - recompensas monetárias ou simbólicas e extensão do trabalho - longas horas de trabalho estariam relacionados aos acidentes.

Nenhum desses fatores, por eles mesmos, causaria acidentes, ou seja, não seria o incentivo que produziria os acidentes, mas as ações dos trabalhadores diante dos incentivos.

\footnotetext{
${ }^{1}$ Relaça social do trabalho - a maneira pela qual é gerenciado o relacionamento entre uma pessoa e seu trabalho (Dwyer 1994, p. 17).
} 
Segundo esse modelo, os ATs seriam uma conseqüência, de como os trabalhadores se relacionam com os perigos de seu trabalho em cada um desses três níveis: o nível organizacional, o de comando e o de recompensa (DWYER 1991; DWYER e RAFTERY 1991).

Uma vez que, os ATs são produzidos por relações sociais de trabalho, considera-se que, mudanças introduzidas nessas relações preveniriam ou contribuiriam para o tratamento de alguns acidentes (DWYER 1991; DWYER e RAFTERY 1991).

Além de DWYER, vários são os autores que analisam o AT, como resultantes das relações de produção e de seus componentes culturais, sociais e econômicos (LAURELL e NORIEGA 1989; LACAZ 1997; LERT et al, 1984) e não apenas como conseqüência da interação dos agentes químicos, físicos, biológicos e ergonômicos (LUCCA e FÁVERO 1994).

FARIA et al (1982) relacionam os ATs com os usos do próprio processo, organização e, em particular, com as longas jornadas de trabalho. Enquanto POSSAS (1980), em sua dissertação de mestrado, alerta para o desgaste físico no processo produtivo, agravado pelas precárias condições de nutrição e saúde, além da falta de dispositivos efetivos de segurança do trabalho.

Como um fenômeno multicausal (ALMEIDA 2001), o AT resulta da interação indesejada de uma rede de múltiplos fatores causais (SCHIMIDT 2003). De natureza complexa, deve ser analisado de forma interdisciplinar (WALDVOGEL 2002) e multidisciplinar, necessitando de uma análise conjugada das ciências epidemiológicas, sociais e econômicas para o seu entendimento (LERT et al 1984), assim, como faz o estudo da saúde pública, que tendo a natureza ontológica definida utiliza-se da epistemiologia de outras ciências (ALVARENGA 1994). 
Enfatiza-se que, enquanto manifestação de relações sociais historicamente determinadas, as resoluções dos ATs situam-se também no campo da luta política (BINDER e ALMEIDA 1997), o que significa, em grande medida, uma luta do próprio trabalhador por melhores condições de trabalho (RODRIGUES e GRAZIANO DA SILVA 1985).

No entanto, no Brasil, é ainda muito comum que a maioria dos ATs seja considerado resultante de um ato inseguro e/ou de condições inseguras (ALMEIDA 2001 e 2003; BINDER e ALMEIDA 1997; BINDER 1994; ZOCCHIO 1980), recaindo a culpa do acidente sobre o trabalhador que, na ânsia de realizar sua função, não tomou os cuidados necessários, ou que, na introdução de uma nova tecnologia, esse trabalhador não soube se adaptar "provocando" um acidente.

Há diversas teorias que buscam levantar os responsáveis pelos ATs, entre elas: Teoria do Puro Acaso, Teoria da Propensão Tendenciosa, Teoria do Alerta, Teoria do Dominó, Teorias Epidemiológicas, dentre outras (ALMEIDA 2001), que se ocupam com a questão do comportamento humano frente aos acidentes, segundo as quais, a investigação, de acordo com Dejours (1997) citado por ALMEIDA (2001, p. 4) “(....) acerca do papel do fator humano nos acidentes assume dois caminhos: o da falha humana e o dos recursos humanos".

Do ponto de vista jurídico, a definição de AT, no Brasil, existe desde 1919. A Lei 8.213, que dispõe sobre os Beneficios da Previdência Social, rege, desde 1991, o AT como todo evento que ocorre pelo exercício do trabalho, a serviço da empresa, provocando lesão corporal ou perturbação funcional que cause a morte ou a redução, permanente ou temporária, da capacidade para o trabalho (Artigo 19). Também, nos Artigos 20 e 21 incluem ainda, como AT, outras entidades mórbidas, entre as quais: as doenças profissionais, os acidentes, ainda que ocorridos fora do horário ou local de trabalho, na execução de ordem da empresa, os acidentes no percurso da residência para o local de trabalho ou, vice-versa, e na hora das refeições (BRASIL, LEI n 8212/91; BRASIL, LEI n 8213/91). 
Nota-se que a Previdência Social considera somente os ATs que resultaram em algum tipo de conseqüência ao trabalhador. Os chamados incidentes, ou seja, aqueles acidentes que ocorreram no local de trabalho, mas não resultaram em vítimas, não são contabilizados. $O$ interesse dessa Instituição, no conhecimento desses acidentes, é para fins indenizatórios. $O$ que é feito através da Comunicação de AT - CAT, que pode ser preenchida pela vítima, empresa, familiares do trabalhador ou médico que o tenha atendido.

Para efeito do nexo causal, a fim de administrar beneficios e indenizações, a Previdência Social considera três categorias para os ATs (RIBEIRO 2000):

- Acidentes-Tipo: são os acidentes decorrentes da atividade profissional desempenhada pelo trabalhador.

- Acidentes de Trajeto: são os acidentes ocorridos no trajeto entre a residência e o local de trabalho e vice-versa (desde que seja o percurso habitual e condizente com os horários de entrada e saída) e os ocorridos nos horários de refeição.

- Doenças do Trabalho: ocasionadas por qualquer tipo de doença peculiar a determinado ramo de atividade.

O AT gera beneficios pagos pela Previdência Social, através do Instituto Nacional de Seguro Social - INSS, e sua notificação é obrigatória para todos os profissionais registrados junto a esta Instituição.

Como se observa, a legislação previdenciária brasileira assume a postura de amparar a vítima do AT, não cogitando a responsabilidade deste ou daquele pelo acontecimento desafortunado (LOPES 1983).

\subsection{Comunicação de acidente do trabalho - CAT: fonte de informação}

Utilizada pela Previdência Social para fins de processamento de beneficios, a Comunicação de AT - CAT - é a fonte básica (MELLO JORGE, GOTLIEB, 
LAURENTI 2001) e principal de informações no estudo dos AT (WÜNSCH FILHO 1995; WALDVOGEL 2001 e 2002; MACHADO e GOMEZ 1995).

As informações geradas pelas CATs envolvem apenas os trabalhadores segurados, cobertos pelo seguro de acidentes, excluindo todos os trabalhadores inseridos no mercado de trabalho informal (LUCCA e FÁVERO 1994; CORRÊA FILHO 1994a) e também os funcionários públicos (RIBEIRO 2000). O que certamente restringe o estudo dos ATs (LUCCA e FÁVERO 1994), uma vez que as estatísticas, apuradas junto à Previdência, não revelam a face real deste sério problema.

Mesmo de notificação obrigatória para todos aqueles com registro na Previdência Social, nem todos os acidentes ocorridos no exercício das atividades laborais são registrados, principalmente, aqueles com menor gravidade que não afastam os trabalhadores de suas atividades (ALMEIDA 2003; WALDVOGEL 2001 e 2002).

A estimativa da OIT é de que o número de AT seja o dobro dos que constam nos relatórios oficiais, devido ao aumento do mercado informal de trabalho (OIT 2004a), que, no Brasil e no Estado de São Paulo, é superior a 50\% (WÜNSCH FILHO 2003). Estima-se que apenas $35 \%$ dos trabalhadores brasileiros têm cobertura por AT (OIT 2004a).Excluindo uma parte considerável da população trabalhadora, os dados devem ser analisados com reservas, não sendo possível estabelecer um panorama epidemiológico completo do que ocorre com a população trabalhadora (MELLO JORGE, GOTLIEB, LAURENTI 2001).

Embora apresente restrição por serem parciais, uma vez que a subnotificação é bastante importante (LIMA et al 1999; CORTEZ 2001), segundo estudo realizado por BINDER e CORDEIRO (2003) em Botucatu, o número de mortes por acidentes de trabalho pode ser quase cinco vezes maior do que o informado pelas notificações 
oficiais. A CAT se constitui como uma das principais fontes sobre AT, representando importante material no dimensionamento da questão acidentária, refletindo a ponta de um gigantesco "iceberg" (POSSAS 1987) e trazendo à tona este grave problema de saúde pública, oriundo dos inúmeros ATs ocorridos no País.

As informações disponíveis obtidas através da coleta de um registro administrativo - CAT - fornecem um painel dos ATs, relativos à população cadastrada na Previdência Social.

Como outros registros administrativos, a CAT centraliza informações sobre casos novos, possibilitando medir a morbidade do grupo economicamente ativo, permitindo verificar e comparar os acidentes entre áreas e atividades econômicas distintas.

Interessados em estudar profundamente esse tema, vários autores (LUCCA e MENDES 1993; WÜNSCH FILHO 1995; WALDVOGEL 2002) ressaltaram as dificuldades em pesquisar o assunto devido às limitações ou à falta de informações estatísticas inerentes ao tema (LUCCA e MENDES 1993). Por isso, o estudo dos ATs enfrenta diversas dificuldades para sua realização (RIBEIRO 2000; WÜNSCH FILHO 1999; LUCCA e FÁVERO 1994).

Apesar dos entraves, esse é um evento social e um fenômeno de saúde pública de suma importância. Acarreta um enorme prejuízo social e pessoal (LUCCA e FÁVERO 1994). Afeta, principalmente, a população em idade ativa, a mais jovem (SANTANA et al 2003). Os ATs podem gerar óbitos, incapacitar cidadãos ou afastálos de suas atividades cotidianas em um período de tempo curto ou longo.

Prejuízo evidente, o AT, traz perdas ao trabalhador, à empresa, ao Estado e à sociedade em geral (DWYER 1994; RIBEIRO 2000). Entretanto, nada supera as vidas precocemente perdidas ou mutiladas no exercício de uma atividade profissional. 


\subsection{PEA e PEA agrícola}

Com o processo de industrialização em franca expansão após a Segunda Guerra Mundial, o Brasil, que até a década de 1940 ainda possuía uma economia de base agrária e população predominantemente rural, atualmente, apresenta uma significativa produção nesse setor. Nos últimos anos, a economia agrária passou por grandes mudanças, modernizando-se e tornando-se competitiva e responsável pelo superávit na balança comercial, através das exportações de soja, açúcar, álcool, laranja, carne bovina e outros produtos agrícolas (CARDOSO e FERREIRA 2002).

Contudo, o crescimento econômico do setor primário no Brasil não ocorreu de forma harmônica e homogênea, privilegia algumas áreas, em detrimento de outras, acarretando, dessa forma, grandes diferenças regionais, quer inerentes aos processos tecnológicos empregados, quer aos próprios padrões socioeconômicos da população rural (DIEESE 2001).

No Brasil, entre as décadas de 1970 e 1990, ocorreu uma alteração significativa na distribuição da População Economicamente Ativa - PEA, segundo o setor de ocupação. Enquanto a classe operária urbana e o setor terciário registraram crescimento, este último tornou-se o setor econômico com maior percentual de ocupação da PEA. O setor primário apresentou retração nesse período (SILVA et al 2003). Em 1970, 44\% da PEA ocupada estava no setor primário, 18\% no secundário e $38 \%$ no terciário, enquanto que em 1990, essa distribuição correspondia a, aproximadamente, $23 \%, 23 \%$ e $55 \%$, respectivamente. No final da década, em 1999 , ocorreu a recuperação no setor primário (Tabela 1), entretanto, em 2001, o Brasil registrou uma participação decrescente desse setor econômico, correspondendo a $21 \%$ da distribuição (SILVA et al 2003).

Com tendência similar à brasileira, o Estado de São Paulo, no decorrer das últimas três décadas, apresentou ampliação do setor secundário, no primeiro período e queda nos períodos posteriores: Um crescimento também foi observado no setor 
terciário da economia, enquanto, o primário apresentou queda, com exceção de 1999, quando registrou um aumento de $9 \%$, em relação a 1990 (Tabela1).

\section{Tabela 1}

População com 10 anos e mais de idade, ocupada, segundo setores de atividade econômica Brasil e Estado de São Paulo $1970 / 1999$

\begin{tabular}{|c|c|c|c|c|c|c|c|c|}
\hline \multirow[t]{2}{*}{ Setor Econôm ico } & \multicolumn{4}{|c|}{ Brasil } & \multicolumn{4}{|c|}{ São Paulo } \\
\hline & 1970 & 1980 & 1990 & 1999 & 1971 & 1980 & 1990 & 1999 \\
\hline Total & 100,0 & 100,0 & 100,0 & 100,0 & 100,0 & 100,0 & 100,0 & 100,0 \\
\hline Prim ário & 44,3 & 29,3 & 22,8 & 24,2 & 20,0 & 12,7 & 6,9 & 7,5 \\
\hline Secundário & 17,9 & 24,9 & 22,7 & 19,3 & 30,7 & 38,5 & 34,5 & 26,1 \\
\hline Terciário & 37,8 & 45,8 & 54,5 & 56,5 & 49,3 & 48,8 & 58,6 & 66,4 \\
\hline
\end{tabular}

Fonte: IBGE - Anuário Estatístico do Brasil 1992 e 2000.

Fundação Seade - Anuário Estatístico do Estado de São Paulo e Fundação Seade - Informe Demográfico no. 28.

Uma questão importante a ser levantada com relação aos postos de ocupação é o tipo de vínculo empregatício que o trabalhador possui: informal ou ter carteira assinada. Esse fator (ter ou não ter carteira assinada) é um dos elementos levados em consideração na avaliação da menor ou maior precariedade do trabalho (FUNDAÇÃo SEADE 2001a). Nesse sentido, as Tabulações Especiais da Pesquisa Nacional por Amostra de Domicílios - PNAD de 1995 e 1999, do IBGE, apontaram uma deterioração nas relações dos empregados agrícolas permanentes ${ }^{1}$ residentes no Estado de São Paulo. Por sexo, observa-se entre as mulheres um declínio acentuado no período compreendido, enquanto em 1995, as trabalhadoras que tinham carteira assinada, respondiam por $64 \%$, em 1999 , esse percentual caiu para $54,8 \%$. Entre os homens, a queda foi menor de $60,1 \%$ para $59,8 \%$, respectivamente.

\footnotetext{
${ }^{1}$ Incluem-se as pessoas a partir dos 10 anos de idade. Excluem-se as. pessoas não-remuneradas ocupadas durante menos de 15 horas na semana, bem como aquelas dedicadas exclusivamente às atividades de auto-consumo e auto-construçăo, inclusive ocupaçðes mal definidas ou não declaradas.
} 
"Ter carteira assinada" significa, automaticamente, contribuição à Previdência Social e assim ter acesso a todos os direitos trabalhistas, tais como à aposentadoria, às pensões e aos pagamentos decorrentes dos AT. Para quem não a possui, as alternativas não são muito animadoras: a contribuição como autônomo ou a ausência dos direitos de aposentadoria ou pensão. Mais uma vez, os dados da PNAD de 1995 e 1999 mostram um declínio na proporção de mulheres que contribuíram para Previdência Social nesse periodo, de $64,0 \%$ para $58,1 \%$ e, entre os homens, essa proporção apresentou um pequeno crescimento, passando de $61,3 \%$ para $62,6 \%$, respectivamente (FUNDAÇÃO SEADE 2001a).

A proporção do tipo de vínculo empregatício do trabalhador e a proporção de contribuintes de Previdência Social indicam, de certa forma, a "abrangência" populacional da CAT entre os trabalhadores agricolas permanentes, pois somente os assegurados podem notificar seu AT na Previdência Social.

\subsection{O AT e o meio rural}

Parcela significativa, os trabalhadores agrícolas representam metade da força de trabalho mundial, uma vez que se estima que 1,3 bilhão de trabalhadores mundiais estão engajados em atividades agrícolas (ALVES FILHO 2001).

Dentre as categorias profissionais, sujeitas a sofrer sérios problemas de saúde no local de trabalho, encontra-se a dos trabalhadores agricolas (NIOSH 2003; NOGUEIRA EA 1994; REVISTA PROTEÇÃO 1992/93; OIT 2004). Essa atividade profissional apresenta um risco maior de sofrer algum tipo de acidente no exercício de suas atividades (ALVES FILHO 2001).

No Brasil, os trabalhadores agricolas foram mais desprotegidos que os trabalhadores industriais pelas condições peculiares em que seu trabalho era realizado e pela menor eficiência da rede geral de saúde nas áreas agrícolas (NOGUEIRA DP 1984). 
Estes trabalhadores apresentam uma gama de atividades bem diversificada que vai desde o simples preparo do solo para o plantio até a colheita, passando pelo transporte e armazenagem dos produtos agrícolas, assim como as inúmeras atividades mais específicas desenvolvidas paralelamente a estas, como: abertura de canais de irrigação e drenagem; construção e manutenção de estradas, silos, armazéns, estábulos, cercas etc.; controle de pragas e doenças; aplicação de adubos. A exploração agrícola também utiliza um número bastante variado de ferramentas, máquinas, implementos, produtos químicos, substâncias inflamáveis, entre outras, sendo que em cada uma dessas atividades podem ocorrer acidentes leves ou graves, comprometendo a saúde do trabalhador (MTB 1981).

Além desses fatores acima citados, o próprio ambiente de trabalho pode representar perigo ao trabalhador rural, entre estes se encontram as insolações, os raios, os animais peçonhentos. Até as próprias culturas agrícolas se constituem em fontes de risco (MTB 1981). Um exemplo disso, é a própria da cana-de-açúcar, que chega a arranhar ou perfurar até os olhos do trabalhador se não tiver protegido.

As cargas de trabalho são os atributos do processo de trabalho cuja presença no ambiente pode aumentar a probabilidade de desenvolver deterioração psicobiológica (GOMES et al 2001), causando aos trabalhadores acidentes ou enfermidades (LAURELL e NORIEGA 1989) e que podem ser identificadas como:

- Cargas fisicas: Derivadas principalmente das exigências técnicas para a transformação do objeto de trabalho e caracterizam um determinado ambiente de trabalho, interagem cotidianamente com o trabalhador (FACCHINI 1994, p. 181).

- Cargas químicas: Derivadas principalmente do objeto de trabalho e dos meios auxiliares envolvidos em sua transformação e também caracterizam o ambiente de trabalho e sua interação cotidiana com o trabalhador (FACCHINI 1994, p. 181).

- Cargas orgânicas: Derivadas principalmente do objeto de trabalho e das condições de higiene ambiental em que ocorre sua transformação (FACCHINI 1994, p. 181). 
- Cargas mecânicas: Derivadas especialmente da tecnologia de trabalho, seja devido a sua operação ou manutenção, aos materiais soltos no ambiente, ao próprio objeto do trabalho $\mathrm{e}$, em particular, às condições de instalação e manutenção dos meios de produção (FACCHINI 1994, p. 181).

- Cargas fisiológicas: Derivadas fundamentalmente das diversas maneiras de realizar a atividade ocupacional e estão constituídas por elementos como o esforço físico e visual, os deslocamentos e movimentos exigidos pela tarefa, o espaço de trabalho disponível, as posiçðes assumidas em sua execução, as horas extras de trabalho ou a intensificação do trabalho, assim como os turnos noturnos e rotativos (FACCHINI 1994, p. 181).

- Cargas psiquicas: Constituídas por aqueles elementos do processo do trabalho que são acima de tudo fonte de estresse, como o ritmo e a intensidade do trabalho, a atenção e responsabilidade que exige a tarefa, o grau de controle e iniciativa à sua execução, a quota de produção prefixada assim como o risco de perder o emprego (FACCHINI 1994, p. 181 e 182).

Presentes no processo de trabalho são distintas para cada ramo produtivo e para cada processo de trabalho, sendo possivel identificar um perfil de cargas de trabalho que configura um determinado padrão de desgaste (FACCHINI 1994).

Para o trabalhador rural, pode ser entre outros: a) cargas fisicas: as intempéries climáticas como chuva, alterações de temperatura, radiação solar; $b$ ) cargas químicas: fuligem de cana queimada, poeira de terra; $c$ ) cargas biológicas: picadas de animais; d) cargas mecânicas: os acidentes de trajeto, os acidentes causados pelas ferramentas de trabalho utilizadas pelos trabalhadores; e) cargas fisiológicas: postura incorreta, movimentos repetitivos; $f$ ) cargas psíquicas: ritmo intenso, monotonia e repetitividade, salário por produção etc. (SCOPINHO et al 1999). 
Os trabalhadores estão expostos cotidianamente às cargas de trabalho que podem desencadear sérios problemas, como doenças de pele, câncer, dores no corpo, esgotamento físico, doenças referentes à coluna, reumatismo e também envelhecimento precoce (NIOSH 2003; BINDER 1994) e, ainda, doenças que previamente diagnosticadas em suas fases iniciais poderiam evitar conseqüências graves aos trabalhadores (DI SANTI 1994).

Pesquisas realizadas junto aos trabalhadores rurais indicam que as ferramentas manuais são os principais causadores de AT (LOPES 1982; VIEIRA et al 1983; ZUCHI 1982; FERREIRA 1998). Isso ocorre até mesmo nas regiões mais modernas da agricultura paulista, como as regiões: Noroeste, Nordeste e CentroOeste (RODRIGUES e GRAZIANO DA SILVA 1985).

Contudo, os trabalhadores rurais não estão sujeitos somente aos ferimentos causados por ferramentas de trabalho (enxadas, facão, "podão") mas, também, a envenenamentos causados por animais peçonhentos ou insolação.

As grandes transformações tecnológicas iniciadas nos anos de 1950 e intensificadas na década de 1970 modernizam as atividades econômicas rurais no Estado de São Paulo (NOGUEIRA EA 1994; FARIA et al 2000). Esse processo de modernização tecnológica alterou significativamente as práticas agrícolas, criando mudanças ambientais, nas cargas de trabalho e nos efeitos sobre a saúde, deixando os trabalhadores rurais expostos a riscos muito diversificados.

Outra questão primordial, e atual, sobre os ATs rurais diz respeito aos movimentos pendulares, que provocou mudanças nos padrões de morbidade da população brasileira. A expulsão dos trabalhadores do campo para a cidade, obrigando-os a se deslocarem diariamente entre suas residências e o local de trabalho, adiciona a esses grupos de trabalhadores os acidentes de trajeto (RODRIGUES e GRAZIANO DA SILVA 1986; ALESSI e NAVARRO 1997). Para os trabalhadores rurais esta questão tem papel fundamental, pois como conseqüência da valorização das terras, os trabalhadores rurais foram expulsos, sendo obrigados a 
migrar para as cidades ou para áreas rurais distantes de seu local de trabalho (ALESSI e NAVARRO 1997).

Segundo o Instituto de Economia Agrícola (IEA/CATI), no final dos anos 90, no séc. XX, cerca de $50 \%$ dos ocupados na agropecuária residiam na área urbana. $\mathrm{O}$ que os obrigava a realizar, todos os dias, deslocamentos entre áreas distantes (BALSADI, BORIM e JULIO 2001), realizados não raras vezes, em péssimas condições, agravadas pela precariedade das estradas, ora em estradas vicinais em mau estado de conservação, ora em auto-estradas movimentadas, e também, pelo tipo de transporte utilizado. Vale ressaltar que este último, em muitos casos, revela-se incompatível com a dignidade humana e com condições de segurança inferiores aos dos produtos (NEVES 1994), elevando a exposição desses trabalhadores aos riscos de acidentes de trajeto (FUNDAÇÃO SEADE/FUNDACENTRO 2001).

Nas regiões canavieiras os acidentes de transporte envolvendo trabalhadores rurais são bastante comuns (RODRIGUES e GRAZIANO DA SILVA 1985 e 1986).

Assim, observa-se que, nos últimos anos, há uma exposição diversificada dos trabalhadores rurais aos ATs (RODRIGUES e GRAZIANO DA SILVA 1986).

Tema também de interesse para o estudo dos ATs no meio rural nos últimos anos foram as significativas alterações no que diz respeito à Lei Acidentária que ocorreram com relação ao trabalho agricola. Até 1991, a classe trabalhadora rural sofria uma diferenciação na forma de pagamento dos beneficios relacionados ao AT, que a deixava em desvantagem se comparada ao trabalhador urbano. Com a lei acidentária de 1991, ocorreram duas importantes alteraçōes. A primeira considera que, para efeito de pagamento de beneficios decorrentes de AT, o trabalhador rural tem os mesmos direitos do trabalhador urbano, equiparando-os em relação ao pagamento dos beneficios (LUCCA e FÁVERO 1994; WALDVOGEL 2002). 
A segunda alteração na lei que beneficiou os trabalhadores rurais refere-se à notificação dos ATs ao Instituto Nacional de Seguridade Social - INSS, que deixa de ser prerrogativa das empresas, podendo ser efetuada pelos sindicatos dos trabalhadores, pelo Sistema Único de Saúde - SUS, e pelos próprios trabalhadores ou ainda por seus familiares (WALDVOGEL 2002; WÜNSCH FILHO 1995; LUCCA e FÁVERO 1994).

Importantes para o dimensionamento dos ATs rurais, essas alterações na lei mostram o interesse em tornar conhecido, principalmente pelas associações de classe e pelos sindicatos rurais, os acidentes associados a estes trabalhadores, através da notificação das ocorrências, nas agências da Previdência Social (FUNDAÇÃOSEADE/FUNDACENTRO 2001).

Nesta perspectiva, a discussão sobre a temática do AT no meio rural é fundamental, visto que as transformações tecnológicas passam a influenciar a vida desses trabalhadores desse setor por meio de fatores como: os acidentes oriundos dos avanços tecnológicos e dos movimentos pendulares que realizam diariamente, entre outros (TEIXEIRA e FREITAS 2003; NOGUEIRA EA 1994).

Como em outras categorias profissionais, os trabalhadores rurais carecem de informações sistemáticas e completas sobre os ATs (FUNDAÇÃo SEADE/FUNDACENTRO 2001), já que as existentes são pouco precisas sobre a situação dos agravos relacionados ao trabalho (WÜNSCH FILHO 2003).

A dificuldade de se obter informação dos acidentes e das doenças do trabalho em área rural não é um fato exclusivamente nacional. HAYDEN (1995) discorre sobre as dificuldades encontradas em trabalhar com este dado, uma vez que falta um sistema de vigilância nacional sobre acidentes na agricultura, nos EUA.

Deve-se salientar que com relação às ações nas áreas de saúde e segurança do trabalho, quando estas ocorrem, são mais ações curativas do que preventivas. De 
forma que o Estado assume um papel assistencial em relação ao acidentado (RIBEIRO 2000; LUCCA e FÁVERO 1994).

\subsection{Trabalho e remuneração}

Com a capacidade de articular ações para um fim determinado, o Homem atua sobre as forças da natureza, submetendo-as ao seu controle, transformando recursos naturais em formas úteis à sua vida (LIEDKE 1997), satisfazendo suas múltiplas necessidades. É através deste ciclo de transformações que a humanidade se desenvolve (BETANCOURT 1999).

Com o trabalho, atividade essencial à existência humana, o Homem se distingue de outros animais e produz sua História. De acordo com Marx, o trabalho “(...) é indispensável à existência do Homem, - quaisquer que sejam as formas de sociedade; - é necessidade natural e eterna de efetivar o intercâmbio material entre o Homem e a natureza, e portanto, de manter a vida humana" (MARX 1987, p.50).

Esse autor, em linhas gerais, distingue as etapas da história humana a partir de sua estrutura econômica, analisando os modos de produção, onde cada um deles distingue-se pelos determinados tipos de relações entre os homens na produção da riqueza. Assim, o modo de produção antigo caracteriza-se pela escravidão; o modo de produção feudal, pela servidão e o modo de produção burguês, pelo trabalho assalariado (MARX 1983). Para Marx, “(....) o que distingue as diferentes épocas econômicas não é o que se faz, mas como, com que meios de trabalho se faz" (MARX 1987, p.204).

Sob o capitalismo, os produtos do trabalho tomam a forma de mercadorias, assim, como a força de trabalho torna-se, também, uma mercadoria. $O$ operário assalariado vende a sua força de trabalho ao proprietário de terra, das fábricas, dos instrumentos de trabalho, como única fonte de sobrevivência. Sujeita-se a ritmos e exigências que lhes são impostos pela produção, com o intuito de sobreviver, por 
meio de um salário. Para os trabalhadores assalariados e sua família, a remuneração é indispensável e influencia diretamente suas condições gerais de vida (OIT 1987).

O sistema de remuneração que está intimamente vinculado à forma de organização do trabalho apresenta, em linhas gerais, dois tipos de sistemas de remuneração: por tempo e por rendimento. Este último, segundo a OIT $(1987$, p.188) pode trazer riscos para a saúde dos trabalhadores, uma vez que consiste em fazer com que o trabalhador produza o máximo pois, neste sistema, o salário é proporcional ao rendimento do trabalhador (OIT 1987).

No que se refere ao trabalhador rural, como bem salientou GRAZIANO DA SILVA (1998), permanente ou volante, assim como o trabalhador urbano, é um proletário, ou seja, um trabalhador desprovido dos meios de produção e, enquanto tal, obrigado a vender a sua força de trabalho para garantir a sua subsistência.

Na maioria das atividades rurais a remuneração é efetivada por produção. $\mathbf{O}$ trabalhador recebe de acordo com a quantidade que produz. As formas de pagamento são as mais distintas: por arroba, como é o caso do algodão; por metro, para o amendoim; por tonelada, para a cana e por caixa, para a laranja. $O$ que obriga 0 trabalhador a realizar um enorme esforço físico para obter uma remuneração menos exígua (NEVES 1994). Os agravos ocupacionais que atingem a população dos trabalhadores rurais decorrem em grande parte do trabalho fisico excessivo (WÜNSCH FILHO 2003).

Trabalho realizado por LOPES na região de Botucatu com dados no FUNRURAL e confirmado por este mesmo autor através de outro trabalho na zona canavieira de Lençóis Paulistas (1982), verificou que o excesso de exercícios e movimentos extenuantes registrou valores de $6,5 \%$ e $3,8 \%$ respectivamente, como causas de acidentes, o que, segundo o autor, dá uma idéia do intenso ritmo de trabalho ao qual estão submetidos os trabalhadores rurais. 
Quando a remuneração do trabalho é feita por produção, isso faz com que o trabalhador, mesmo estando cansado, continue trabalhando intensamente com o intuito de atingir sua meta (GOMES et al 2001), tornando a atividade mais penosa (FERREIRA 1998).

Dessa forma, a remuneração por produção ocorre às custas de um esforço físico que provoca desgastes que se refletem na saúde do trabalhador, provocando, em poucos anos, sérios prejuizos a saúde (DIEESE 2001).

Nesse sentido, o ritmo extenuante de trabalho, além de provocar acidentes de modo direto, também ocasiona o aparecimento da fadiga que, freqüentemente, está associada aos demais acidentes (RODRIGUES e GRAZIANO DA SILVA 1985).

No caso da cana-de-açúcar, o trabalhador tem duas formas distintas de pagamento: recebe menos pelo corte da chamada cana queimada e mais pela cana crua. $\mathrm{O}$ corte da cana crua ou cana verde, além de ser considerado mais dificil, exige mais força e requer mais tempo, também apresenta mais perigo, uma vez que os animais peçonhentos existentes no canavial não foram afastados ou dizimados do local de trabalho como ocorre após o processo de queimada (FERREIRA et al 1998).

Por outro lado, o processo de queimada é um problema ambiental sério que suscita várias discussões, além de prejudicar a saúde dos trabalhadores e da população das cidades próximas ao canavial, em razão da fuligem emitida pelo fogo. Ocasiona a dizimação da fauna que existe nesse habitat, tanto que quando a cana é cortada e retirada do seu local de origem, é possível observar aves de rapina, cobras entre outros animais que a queimada dizimou (SCOPINHO et al 1999). No entanto, essa prática vem sendo defendida por muitos agricultores, empresários e até mesmo trabalhadores rurais do Estado de São Paulo (JORNALCANA 2002).

Entre as dificuldades enfrentadas, com a restrição da queima da cana-deaçúcar, está a queda do rendimento do trabalhador rural, que se reduz até a metade 
com a mudança para o sistema de colheita de cana crua, o que encarece significativamente a operação na cultura. Muitos autores também afirmam que o rendimento das colhedoras mecânicas sob o sistema de cana crua é de 20 a $30 \%$ inferior ao sistema tradicional, devido à presença da palha que dificulta a operação (JORNALCANA 2002).

\subsection{Processos de produção e de trabalho no meio rural}

Na compreensão marxista, os componentes do processo de trabalho são: o trabalho propriamente dito; a matéria sobre a qual se aplica o trabalho e os meios de trabalho, que são os instrumentos utilizados pelo trabalhador. Segundo LIEDKE (1997), é o instrumental disponível que distingue as condições sociais nas quais se realiza o trabalho em um dado período histórico. Cada período histórico disporia de um instrumento transformador da natureza específico, mais rudimentar como nos primórdios da história ou mais modernos como a máquina a vapor, depois da Revolução Industrial.

No Brasil, as transformações nas relações de trabalho no campo processaramse de forma mais intensa nas regiōes Sudeste e Centro-Oeste do que no Nordeste brasileiro (SILVA et al 2003). No final dos anos de 1950, ocorreu a modernização agrícola que se intensificou nas década de 1970 e 1980, principalmente no Estado de São Paulo, que já apresentava grande parte de suas atividades agrícolas voltadas para a exportação, entre outros alimentos, do açúcar e da laranja.

O crescimento das exportações exigiu um aumento da produção e, dessa forma, por exemplo, tanto a cultura da cana, como a da laranja foram, e têm sido, impulsionadas pelo setor industrial. Entretanto, o aumento da produção não representou maior utilização de força de trabalho (DIEESE 2001). No decorrer da década de 1990, o Estado de São Paulo apresentou uma queda no contingente de pessoas ocupadas na agropecuária, em decorrência da incorporação de modernas tecnologias disponíveis para os agricultores, principalmente aquelas destinadas às 
operações de colheita e pós-colheita; de 1.261 mil trabalhadores, em 1992, passaram a 944 mil, em 1998, segundo os dados da PNAD (BALSADI, 2001).

Além disso, a contínua modernização na agricultura, com incorporação sistemática da tecnologia, trouxe mudanças significativas no assalariamento do trabalhador rural. Apesar da geração de postos de trabalho mais especializados, a ocupação agrícola continua a se caracterizar pela precariedade e pelas más condições de trabalho (DIEESE 2001). Mesmo com o alto desenvolvimento tecnológico no setor primário do Estado de São Paulo, existe uma parcela expressiva de trabalhadores rurais em atividades braçais penosas, condições de trabalho precárias e risco de vida. Como é o caso dos cortadores de cana-de-açúcar, onde a falta de segurança, o esforço físico e os acidentes marcam, desfavoravelmente essa atividade (REVISTA PROTEÇÃO 2003; FERREIRA et al 1998).

Em suma, as mudanças ocorridas refletiram-se nas relações de trabalho no campo e em agravos à saúde dos trabalhadores (WÜNSCH FILHO 1995); as contínuas alterações ocorridas no trabalho, particularmente, nas últimas décadas, com a introdução de tecnologias, que em certos casos substituíram o trabalho humano (WÜNSCH FILHO 2003), apresentam diversas conseqüências para a saúde dos trabalhadores brasileiros, o meio ambiente, as cargas de trabalho e os efeitos sobre a saúde, tornando os trabalhadores rurais expostos a riscos muito diversificados (FARIA et al 2000).

\subsection{AT no meio rural e a questão de sexo}

A primeira divisão social do trabalho é a divisão sexual que se fez em consequiência da procriação (NOGUEIRA 2003). Moldada histórica e socialmente, tem como característica o domínio dos homens na esfera produtiva e das mulheres na esfera reprodutiva (KERGOAT 2000).

Responsável pela manutenção da subsistência e da reprodução, cabia à mulher a esfera doméstica como espaço de trabalho (NOGUEIRA CM 2003) onde, 
por meio de gestos repetitivos e atos cotidianos, mantinha o lar e a educação das crianças (HIRATA 2000), assim como a alimentação e higiene dos homens e dos menores. Aos homens, com domínio do espaço público, cabia a subsistência desse lar.

A partir das transformações ocorridas no mundo produtivo, suscitadas pela Revolução Industrial, a presença feminina se amplia no mundo do trabalho (NOGUEIRA CM 2003).

A inserção da mulher no mercado de trabalho é cada vez mais ampla, tornando-se uma força de trabalho não mais auxiliar do homem, mas uma outra categoria de trabalho (NOGUEIRA EA 1994).

Se a classe operária tem dois sexos (SOUZA-LOBO 1991), a História mostra que a participação da mulher nas atividades rurais sempre foi intensa, inicialmente absorvida na estrutura de produção familiar. Hoje se verifica a crescente participação da mulher no trabalho assalariado rural (BAPTISTELLA et al 2000).

Os dados do Censo Agropecuário de 1995/96 indicam que neste setor de trabalho predominantemente masculino, a força de trabalho agricola nesse periodo era composta por $23 \%$ pelo sexo feminino, mas com participação proporcionalmente crescente (BAPTISTELLA et al 2000). "A participação da população feminina (mais de 15 anos) residente nos imóveis rurais, em relação ao trabalho masculino, era de $21,1 \%$ em 1990, ficando ao redor de $28,0 \%$ em 1999, embora, em termos absolutos, tenha ocorrido um decréscimo de 16,5 mil mulheres ocupadas(....)" (BAPTISTELLA et al 2000, p.20).

Segundo dados da PNAD de 1999, entre os empregados residentes rurais agricolas mais de $60 \%$ era de composto por trabalhadores permanentes. Por sexo, 
esse percentual, em 1999 foi de 60,8\% para o sexo feminino e de $62,8 \%$ para o sexo masculino (FUNDAÇÃo SEADE 2001a) ${ }^{3}$.

Com referência à cana-de-açúcar, desde da época da produção familiar, a participação feminina sempre foi observada em várias tarefas, principalmente no periodo da colheita (SILVA 2000). Com o surgimento das grandes usinas, quando ocorre a expulsão da mão-de-obra residente no campo e aparece o trabalhador volante, individualizado e não mais familiar, a mulher, agora força de trabalho individualizada, continua exercendo diversas tarefas relacionadas à carpa, ao plantio, à distribuição de pesticidas e principalmente à colheita, parte do processo de trabalho que emprega mais mão-de-obra (SILVA 2000).

Não existe divisão sexual do trabalho na cana manual, pois ambos os sexos participam de todas as etapas de trabalho, desde o preparo do solo, plantio, ao corte e distribuição de pesticidas.

Com relação à laranja, segundo BAPTISTELLA, o único momento em que apresentou a divisão sexual do trabalho, foi no repasse do pomar (quando o trabalhador retorna ao pomar para colher os frutos que não estavam maduros na época da primeira colheita). Nesse caso, os homens colhem os frutos jogando-os no chão e as mulheres passam recolhendo esses frutos. Como o pagamento é feito por produção, divide-se o valor da mesma entre todos os trabalhadores envolvidos (BAPTISTELLA 1998).

Com papéis sexuais distintos na sociedade, observa-se pouca ou nenhuma divisão sexual no processo de trabalho realizado no corte de cana-de-açúcar ou da colheita da laranja, nestas duas culturas as condições de trabalho são as mesmas para ambos os sexos, pelo menos no que se refere ao corte manual. Com relação ao corte mecanizado, um estudo realizado por SILVA (2000) conclui que a grande maioria

\footnotetext{
${ }^{3}$ Incluem-se as pessoas a partir dos 10 anos. Excluem-se as pessoas não-remuneradas ocupadas durante menos de 15 horas na semana, bem como aquelas dedicadas exclusivamente às atividades de auto-consumo e auto-construção. Inclusive ocupaçðes mal definidas ou não declaradas.
} 
das mulheres é excluída do processo produtivo, dado que as gigantescas máquinas são operadas unicamente por homens, enquanto às mulheres são relegadas as piores tarefas.

Vale a pena salientar, que a divisão entre os sexos atravessa a sociedade, ultrapassando o espaço da empresa, além do trabalho na lavoura, as mulheres exercem tarefas domésticas, configurando a dupla jornada de trabalho, essa realidade exige uma análise detalhada do papel sexual do homem e da mulher na sociedade, com uma introdução de categoria por gênero.

A análise por sexo, observada neste levantamento, é fundamental para a caracterização demográfica e epidemiológica, uma vez que as diferenças biológicas entre os sexos existem e demandam necessidades distintas.

\subsection{Processo de produção nas culturas da cana-de-açúcar e das frutas cítricas}

De grande importância econômica tanto para o Brasil como para o Estado de São Paulo, a cana-de-açúcar e os produtos cítricos são, junto com o café, as principais lavouras (em valor) do Estado (ANDRIETTA 2002).

O cultivo da cana e a fabricação do açúcar são atividades tradicionais no Brasil. Nos séculos XVI, XVII e XVIII, era a principal atividade econômica da colônia. Essa atividade era baseada no plantio monocultor em latifúndios e utilizava mão-de-obra escrava (CONDÉ 1971/1972).

Foi em 1530, com Martins Afonso de Souza, que as primeiras mudas de canade-açúcar vindas da Ilha da Madeira foram plantadas na Capitania de São Vicente, onde foi construido o primeiro engenho de açúcar com o nome de Engenho do Senhor Governador (CONDÉ, 1971/1972). 
Cerca de oito anos mais tarde, por volta de 1538 , iniciou-se a plantação dessa cultura na Capitania de Pernambuco que em pouco tempo tomou-se a capital açucareira do Brasil. Devido ao sucesso e com o apoio financeiro dos comerciantes portugueses, logo se estendeu para todo o recôncavo baiano, alastrando-se mais tarde por toda a orla litorânea nordestina do Rio Grande do Norte até Alagoas (ÚNICA 2003; CONDÉ 1971/1972). Nessa época, a força de trabalho era a escrava e o senhor de engenho era autoridade absoluta

No século XIX, com a introdução de novos concorrentes internacionais há uma queda significativa da produção brasileira de açúcar. Ainda, no final desse século, o Brasil vive a euforia do café, concentrada já no interior paulista, quando a força de trabalho escrava é substituída pela imigrante, principalmente italiana (ÚNICA 2003).

Contudo, paralelo às fazendas de café, concentraram-se na região compreendida no quadrilátero formado entre Campinas, Itu, Moji-Guaçú e Piracicaba, inúmeros engenhos de cana-de-açúcar. Também, formaram-se novos engenhos, mais ao norte do Estado, nas vizinhanças de Ribeirão Preto (ÚNICA 2003).

$\mathrm{Na}$ virada do século, Piracicaba, que já possuía em sua região três dos maiores engenhos centrais do Estado e usinas de porte como a Ester, a Santa Bárbara e a Monte Alegre, rapidamente se tornou o maior centro produtor de açúcar de São Paulo (ÚNICA 2003).

A partir da década de 1910 , impulsionadas pelo crescimento da economia paulista, os engenhos de aguardente foram rapidamente se transformando em usinas de açúcar, dando origem aos grupos produtores mais tradicionais do estado na atualidade (JORNALCANA 2000). 
Em 1929/30, com a crise internacional do café, as plantações de cana-deaçúcar se espalharam pelo Estado de São Paulo, ocupando juntamente com o algodão, antigas áreas de produção desse produto.

Com a subordinação da agricultura à indústria no final dos anos de 1950, ocorre a modernização agrícola, através da ampliação de insumos químicos, aumento do uso da força mecânica, aprimoramento de raça, entre outros; acarretando, principalmente, o aumento da produtividade com menor utilização de mão-de-obra (SILVA et al 2003).

Já na década de 1950, a agricultura paulista era considerada a mais moderna e avançada do País, com grande parte das atividades voltadas para a exportação de açúcar, laranja e alimentos que se concentravam em São Paulo.

A contínua modernização ocorrida na agricultura nos anos de 1960 e 1970 com incorporação sistemática da tecnologia trouxeram mudanças significativas no assalariamento do trabalhador rural. Apesar da geração de novos postos de trabalho, a ocupação agrícola se caracteriza pela precariedade e pela má qualidade dos postos de trabalho (DIEESE 2001).

Esse processo tornou-se mais intenso nos anos de 1980, quando a mecanização e a quimificação da agricultura tiveram um grande avanço, reduzindo drasticamente a necessidade de força de trabalho, tanto dos assalariados permanentes que foram os mais afetados, quanto dos temporários. $\mathrm{O}$ aumento de produção já não representava, necessariamente, abertura de mais postos de trabalho (DIEESE 2001).

A crise do petróleo de 1973 estimulou a implementação do PROÁlCOOL programa que incentivava a produção de álcool anidro para substituir a gasolina - em 1975. O subsídio fornecido pela Petrobrás promoveu um verdadeiro "boom" de produção de álcool. A partir de 1960 a área cultivada de cana aumentou em $200 \%$ (JORNALCANA 2000). 
Depois da redução dos preços do petróleo no mercado internacional, a produção de álcool conseguiu se manter por um certo tempo, mas apresentou redução na década de 1990 . No entanto, há uma retomada da produção do açúcar voltada tanto ao consumo doméstico quanto à exportação (JORNALCANA 2000).

Atualmente as principais zonas produtivas são a Zona da Mata Nordestina (Alagoas e Pernambuco), a Zona da Baixada Fluminense e da Mata Mineira e o Estado de São Paulo.

Regionalmente, no Estado de São Paulo, as lavouras de cana-de-açúcar encontram-se espalhadas praticamente por todo o Estado. Entretanto, o destaque situa-se nas mesorregiões de Ribeirão Preto, Araraquara, Bauru, Piracicaba, São José do Rio Preto e Araçatuba (Figura 2).

A cana-de-açúcar é um dos produtos agrícolas de maior relevância do Estado. Sua área colhida correspondia, em 1995/96, a cerca de 51\% da produção brasileira (IBGE, 1995/96) o que, sozinha, garante o suprimento da indústria açucareira, que se firmou como uma das mais importantes do país (BELIK et al 1999). Segundo dados da Pesquisa de Atividade Econômica Paulista - PAEP 96 - realizada pela Fundação Seade em 1996, a produção de cana-de-açúcar se sobressai na atividade agroindustrial $^{4}$ em São Paulo, destacando-se neste setor, no que se refere aos indicadores de emprego (quase 87,9 mil, ou seja, 39,4\% do pessoal ocupado no ramo agroindustrial), receita líquida de 7,5 milhões, o que corresponde a $32 \%$ da receita das agroindústrias paulistas e valor adicionado de 2.7 milhões, $30,7 \%$ das agroindústrias paulistas (BELIK et al 1999).

\footnotetext{
${ }^{4}$ Considerou-se agroindústria as atividades ligadas ao primeiro processamento de matérias-primas derivadas da agropecuária.
} 
Figura 2 - Produtos de lavoura temporária e permanente, por área colhida (Hectare). Mesorregiões Geográficas do Estado de São Paulo $1995 / 1996$

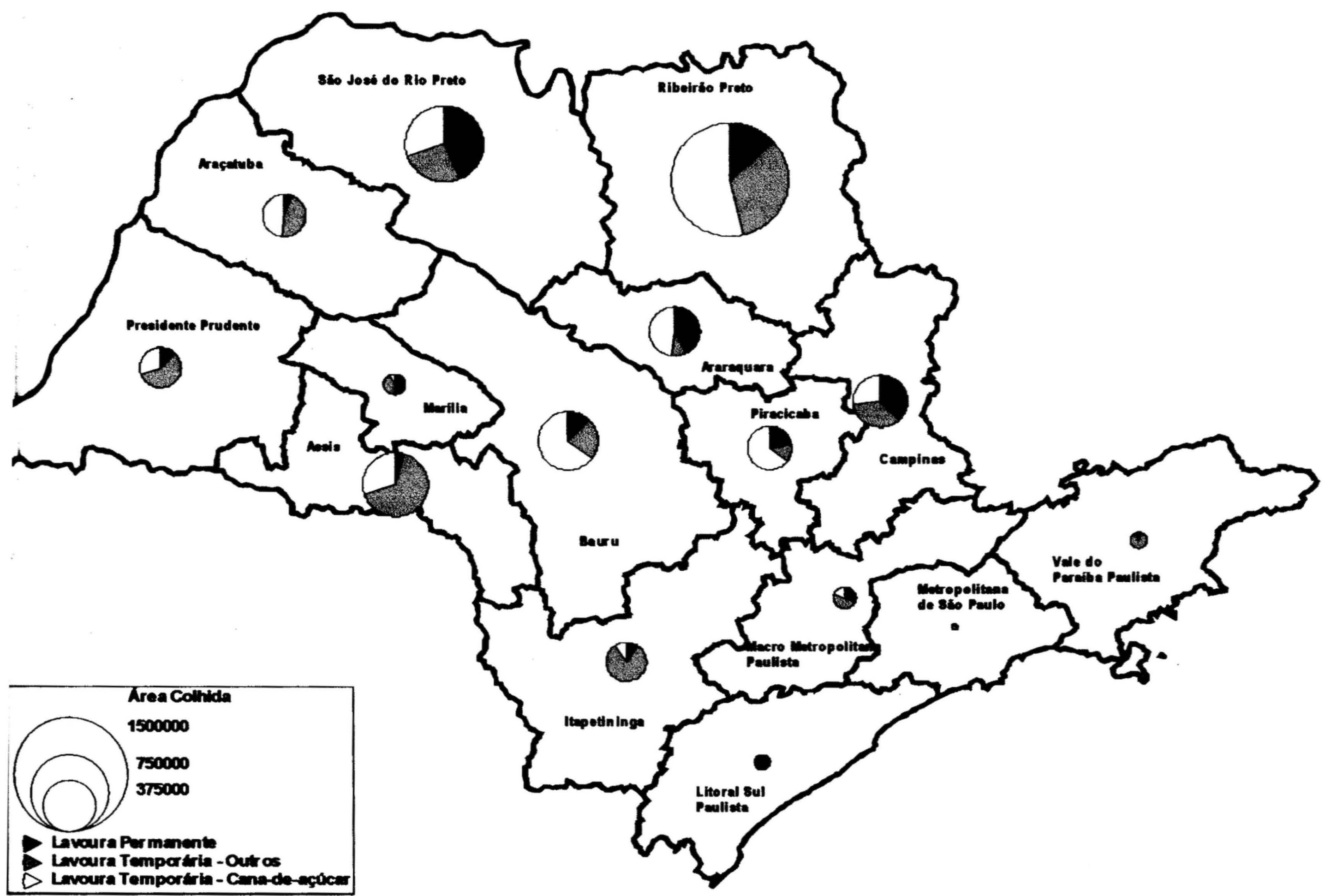

Fonte: IBGE - Censo Agropecuário de 1995/1996. 
Considerando-se que, em São Paulo, 75\% da cana-de-açúcar ainda é cortada manualmente após o processo de queimada, como há 100 anos (REVISTA ECOLOGIA e DESENVOLVIMENTO 2000), o desgaste físico e o número de AT envolvendo esses trabalhadores são enormes, em razão das queimadas, da postura física exigida para o corte da cana e do simples uso de suas ferramentas básicas de trabalho, como o afiado facão ou podão (TEIXEIRA e FREITAS 2003; NOGUEIRA EA 1994; FERREIRA et al 1998).

As modernizações ocorridas na cultura da cana-de-açúcar, como a introdução de novos equipamentos e máquinas, entre eles, colhedeiras, caminhões-tanque, caminhões oficinas equipados (com prensa, macaco, furadeira etc.), modificaram as relações de trabalho e intensificaram, ainda mais, o ritmo de trabalho da lavoura (SCOPINHO et al 1999). Em outras palavras, porque o trabalhador passa a submeter seu ritmo de trabalho à máquina, que mantém um ritmo contínuo, parando somente para abastecer. Além de estender o trabalho também para o período noturno, o que não existe no corte manual, pois este é diurno (SCOPINHO et al 1999). A introdução de modernas máquinas agrícolas não tem necessariamente contribuído com os trabalhadores rurais no sentido de melhorar suas condições de vida, pelo contrário, além de alterarem o ritmo de trabalho, estas ainda ameaçam o emprego desses trabalhadores (SCOPINHO et al 1999). Salienta-se que alguns modelos de máquina em condições ideais de trabalho ${ }^{5}$ chegam a realizar sozinhas o trabalho que exigiria a presença de 100 a 130 homens numa jornada de 10 horas de trabalho (ALVES 1993).

Entretanto, salienta-se que em razão do declínio acentuado ${ }^{6}$ de algumas áreas de plantio do Estado, onde não é possivel o uso de colhedeiras ou de outras máquinas agrícolas, a presença do homem é indispensável.

\footnotetext{
${ }^{5}$ Condiçaes ideais de trabalho: terrenos planos, espacamento adequado, cana mais ereta e infraestrutura de apoio (ALVES 1993).

${ }^{6}$ Ou seja, declividade superior a $12 \%$
} 
Pesquisa realizada pelos produtores de açúcar e álcool - SOPRAL, no Estado de São Paulo concluiu que, aproximadamente, $60 \%$ da área plantada com cana pode ser imediatamente mecanizada, $20 \%$ é mecanizável, mas exige investimento para adequação do terreno e $20 \%$ não é mecanizável, o que sempre garantirá a presença do homem com o corte manual (SCOPINHO et al 1999; JORNALCANA 1993). O conceito de "área mecanizável" segue basicamente uma limitação topográfica, segundo a qual, terrenos com declividade superior a $12 \%$ não são passíveis de mecanização, em razão do aumento do percentual de perdas em matéria-prima, e do risco de capotamento da máquina colhedora (SCOPINHO e col. 1999).

Além disso, as máquinas não conseguem cortar alguns tipos mais resistentes de cana, como por exemplo, a cana "rolo", cana que passou do ponto de corte, ficando muito grande, cai com o vento, enrola-se e, às vezes se enraiza; nesses casos, é o trabalhador que fica encarregado de cortá-las, uma vez que a máquina não consegue fazê-lo (FERREIRA et al 1998).

Com relação ao complexo citricola paulista, a laranja é o principal produto da lavoura permanente ${ }^{7}$ no Estado de São Paulo, onde é responsável por $85 \%$ da produção brasileira por mil frutos (IBGE 1995/96). Segundo GRAZIANO DA SILVA (1999), esta foi uma das atividades que mais apresentou crescimento entre 1985 e 1996, quando a produção passou de 218 milhões de caixas de 40,8 $\mathrm{Kg}$ para 335 milhões.

Provavelmente de origem asiática, a laranja atualmente apresenta os pomares mais produtivos do mundo, nas regiões de clima tropical e subtropical, destacando-se o Brasil, Estados Unidos, México, China e África do Sul, sendo os principais

\footnotetext{
${ }^{7}$ Lavoura Permanente: Área plantada ou em preparo para o plantio de culturas de longa duraçăo, que após a colheita ñ̃o necessitam de novo plantio, produzindo por vários anos sucessivos. Incluídas nesta categoria as áreas ocupadas por viveiros de mudas de culturas permanentes.

Lavoura Tempordria: Áreas plantadas ou em preparo para o plantio de culturas de curta duração (via de regra, menor que um ano), e que necessitam, geralmente de novo plantio após cada colheita, inclúse também nesta categoria as áreas das plantas forrageiras destinadas ao corte.
} 
produtores mundiais São Paulo, no Brasil, e Flórida, nos Estados Unidos (HASSE 1987; ABECITRUS 2004).

No Brasil, a citricultura ganha espaço com a crise do café, no inicio do século XX, mas foi somente em 1939 que a laranja passou a ser um dos produtos de exportação mais importantes do País, sendo a principal região São Paulo. No início da década de 1960 a indústria brasileira de suco e outros subprodutos da laranja ganhou impulso, isso porque ocorre em 1962 uma grande geada que destruiu grande parte da citricultura dos Estados Unidos (HASSE 1987).

Em meados 1963, foi instalada a primeira grande fäbrica de suco de laranja no Estado, na região de Araraquara (SUCONASA), que alterou a produção da laranja, anteriormente destinada ao comércio de frutas in natura dirigida ao mercado interno e externo (BAPTISTELLA 1998). Nessa época a indústria cítrica brasileira exportou mais de cinco mil toneladas de suco, arrecadando pouco mais de dois milhões de dólares (ABECITRUS 2004).

Favorecido principalmente pelas boas condições do mercado internacional, como o crescimento da demanda e das sucessivas quebras de safra norte-americanas, decorrentes das geadas significativas ocorridas no Estado da Flórida, EUA, nos anos 1981, 1982, 1983, 1985, 1987 e 1989 (BAPTISTELLA 1998), o Brasil vê sua produção disparar, tornando-se, já nessa década, o maior produtor mundial.

Hoje é o País que detém o maior pomar cítrico do mundo e destina sua produção, quase que exclusivamente, ao mercado externo. Com mais de um milhão de hectares de plantas cítricas em seu território, a maior parte da produção brasileira de laranjas destina-se à indústria do suco, concentrada no estado de São Paulo, responsável por $70 \%$ das laranjas e $98 \%$ do suco que o Brasil produz (ABECITRUS 2004). 
Segundo dados da Secretaria da Agricultura e Abastecimento do Estado de São Paulo, a laranja ocupa em 2000 uma área de 737 mil hectares, inferior apenas à cana e às pastagens. Com 207 milhões de árvores, 15\% em fase de formação, o que indica um crescimento da produção nos próximos anos. A estimativa é que o setor gere cerca de $\mathbf{4 0 0}$ mil empregos diretos e indiretos, mas de um bilhão de dólares de exportação e uma arrecadação para o Estado de São Paulo de 350 milhões de dólares por ano de ICMS (SILVA et al 2000 e ROMEIRO 2002).

Como a cana, a colheita também é realizada de forma manual, o uso de máquinas agricolas nessa cultura está atualmente em caráter experimental (BAPTISTELLA et al 2000), levando os trabalhadores a um grande desgaste físico no exercício diário de suas funções.

Com relação à utilização da força de trabalho, a laranja, ao lado das culturas do café e da cana-de-açúcar, é uma das maiores fontes de geração de empregos na agricultura paulista (BAPTISTELLA 1998).

Esta cultura junto com a cana-de-açúcar, além de ser uma das grandes responsáveis pela ocupação de mão-de-obra no campo, no processo de plantio e colheita demanda por um grande número de trabalhadores, apresentam também as maiores arrecadações do Estado (BELIK et al 1999; BALSADI et al 2001).

Com participação também significativa, a agroindústria do suco registrava, em 1996 no Estado de São Paulo, 10.502 empregos (4,7\% do pessoal ocupado no ramo agroindustrial) e uma receita líquida de 1,4 milhões, correspondendo a $6,1 \%$ da receita das agroindústrias paulistas e a um valor adicionado de 707 milhões, 8,1\% entre as agroindústrias paulistas (BELIK et al 1999).

Quanto à laranja, as principais áreas paulistas vão da Região de Campinas ao extremo norte do Estado, na mesorregião de São José do Rio Preto (BAPTISTELLA 1998). 


\subsection{Processo de trabalho nas culturas da cana-de-açúcar e das frutas cítricas}

Setores econômicos de destaque no Estado de São Paulo, tanto a cana-deaçúcar como os produtos cítricos, possuem trabalhadores que exercem atividades extenuantes, repetitivas, manuais e desgastantes; é a dicotomia entre riqueza e pobreza que se processa no mesmo espaço.

Como empregadores de uma grande quantia de força de trabalho, a laranja e a cana apresentam um número grande de acidentes, contudo, além de analisar a freqüência desses eventos, é importante verificar como se acidentam esses trabalhadores e onde se encontram regionalmente.

A dimensão do problema atinge todos os trabalhadores envolvidos no processo de plantio e colheita dessas grandes culturas, não só cortadores e colhedores, mas também os motoristas, os operadores de máquinas agrícolas, dos quais é exigida maior qualificação profissional, entre outros.

A seguir relaciona-se a descrição das tarefas realizadas pelos trabalhadores que se encontram na cultura da cana-de-açúcar e das frutas cítricas.

\section{Cana-de-açucar}

Cortadores: segue a seguinte seqüência dos movimentos:

- Apanha, em geral com o membro superior esquerdo, o feixe de cana (de quatro a cinco plantas);

- Curva-se;

- Golpeia com o facão à base dos colmos (rente a terra) com membro superior direito;

- Levanta o feixe; 
- Depois do corte, o trabalhador joga o feixe sobre o ombro e o carrega por uma distância de aproximadamente 2 metros, depositando-o na área já cortada (FERREIRA et al 1998; GOMEZ et al 2001).

Operadores de Colhedeiras: presentes no corte mecanizado, estes trabalhadores são responsáveis pelas máquinas que cortam a cana. Operam suas máquinas acompanhadas de um outro veículo que traciona uma caçamba que tem como função receber a cana cortada por eles. Quando essa caçamba é preenchida é levada por um trator ao caminhão transportador, o qual fica fora do "talhão"8.

Esse tipo de atividade apresenta ritmo intenso e ininterrupto, pois as colhedeiras não param, chegando a cortar em média 3.900 toneladas/dia. Em razão de apresentarem funcionamento ininterrupto, a jornada de trabalho se estende ao turno noturno.

Quanto à remuneração, é por horas trabalhadas e não mais por produção, como no corte manual (SCOPINHO et al 1999). Por apresentar um rendimento aproximadamente superior a $30 \%$ ao corte da cana crua de forma geral, o corte mecanizado também é realizado após o processo de queimada (SCOPINHO et al 1999).

Motorista de caminhão: profissionais encarregados de transportar a cana cortada do canavial ao pátio de descarregamento da usina. No corte mecanizado esse processo em razão da rapidez que é realizado é conhecido como "Bate e Volta" (SCOPINHO et al 1999).

\footnotetext{
${ }^{8}$ Talhăo é a designação dada a uma área cultivada no canavial. É composto por várias linhas de canas plantadas paralelas, não tem uma medida especifica e pode medir de 2 a 20 hectares (FERREIRA et al 1998).
} 
Devido ao grande fluxo de caminhões é comum dentro e na saída do canavial um tráfego intenso (GOMEZ et al 2001), o que pode provocar diversos acidentes. Na colheita da laranja encontram-se os trabalhadores:

Colhedor ou coletor - realiza dois tipos distintos de colheita:

- Colheita seletiva: a colheita é selecionada por tamanho, coloração e limpeza da casca.

Nesse caso é realizada com corte do pedúnculo; é empregada na colheita das tangerinas e nas frutas destinadas à exportação (BAPTISTELLA et al 1998).

- Colheita Limpa-pé: são colhidas todas as frutas maduras.

A colheita, em geral, é realizada com torção do pedúnculo e é característica da colheita das frutas destinadas à indústria do suco (BAPTISTELLA 1998).

Em ambos os tipos de colheita, as frutas são colocadas em sacolas especiais para colheita que os trabalhadores levam lateralmente ao corpo. Quando cheias, seu conteúdo é transferido para as caixas (25 a $27 \mathrm{Kg}$, em média, cada) (BAPTISTELLA 1998).

Carregador Manual: Comum na colheita convencional, a este trabalhador cabe transferir as frutas das caixas para a carroceria do caminhão, recolher as frutas do chão, distribuir caixas vazias. Em média existem três carregadores por turma (BAPTISTELLA 1998).

Apontador/Fiscal/Feitor: responsável em anotar o número de caixas colhidas de cada colhedor, anotar irregularidades na fruta, qualidade da colheita, caixas não completamente cheias. (BAPTISTELLA 1998). 
Motorista: Existem dois tipos de motoristas:

- Os encarregados de transportar a fruta do pomar até o depósito tipo bins (espécie de silo) feito por caminhões ou tratores, que também são operadores de Braço Mecânico (Carregador): Estes profissionais são responsáveis em retirar as frutas do sacolão ou container ${ }^{9}$, onde são depositadas pelos colhedores. Para tanto, utiliza um braço mecânico tipo Munk; instalado no caminhão ou trator; transporta as frutas até o depósito (BAPTISTELLA 1998) e;

- os motoristas encarregados de transportar a fruta dos Bins (espécie de silo) até a indústria, essa parte é realizada por caminhões maiores.

Nem todas as empresas possuem esses dois tipos de motoristas responsáveis pelo escoamento da produção. Em algumas empresas, existe somente um motorista que transporta a fruta diretamente do pomar até a indústria.

As empresas que apresentam o sistema de escoamento da produção em duas etapas, não apresentam tráfego de caminhão no interior do pomar (BAPTISTELLA 1998).

Vale ressaltar, que os profissionais envolvidos na colheita da laranja das indústrias cítricas paulistas são registrados em carteira e possuem no mínimo a idade de 14 anos (BAPTISTELLA 1998).

\footnotetext{
${ }^{9}$ O sacolão ou container corresponde entre 20 e 25 caixas de frutas.
} 


\section{OBJETIVOS}

\subsection{Objetivo Geral}

Descrever e analisar os registros de AT da base de dados Seade/Fundacentro do Estado de São Paulo no período de 1997 a 1999, para as categorias profissionais envolvidas nas culturas sucroalcooleira e cítrica - cortadores, colhedores, motoristas e operadores de máquinas agrícolas.

\subsection{Objetivos Específicos}

Analisar os ATs nas culturas sucroalcooleira e cítrica no Estado de São Paulo entre 1997 e 1999, segundo:
a) tipo de AT;
b) conseqüência do $\mathrm{AT}$;
c) sexo;
d) idade e
e) partes do corpo atingidas.

Estimar e analisar para o total dos acidentes registrados no meio rural e para os trabalhadores das culturas sucroalcooleira e cítrica do Estado de São Paulo, entre 1997 e 1999, os coeficientes de:
a) incidência acumulada;
b) mortalidade e
c) letalidade. 


\section{MATERIAL E MÉTODO}

\subsection{Delineamento do estudo}

Este é um estudo descritivo de corte transversal repetitivo com três incidências anuais acumuladas obtidas retrospectivamente dos ATs ocorridos do meio rural, registrados junto à Previdência Social entre 1997 e 1999 no Estado de São Paulo.

O levantamento repetido em três anos se aproxima dos chamados estudos de painéis, que são séries de estudos transversais, que têm por objetivo estimar as mudanças na situação da saúde em relação às alterações de exposição (CHECKOWAY et al 1989). Nesse tipo de análise podem ser incluídos novos sujeitos, por isso o que está sendo observado e medidos são os eventos.

Todos os dados coletados referem-se a um momento passado, onde será calculada a acumulação de casos novos ao final do ano. Os indicadores de freqüência que levam em consideração o número de casos observados no período de avaliação (numerador) e a população exposta (denominador), calculados neste estudo são a incidência acumulada, a mortalidade e a letalidade.

A incidência acumulada é um coeficiente que representa uma estimativa do risco de desenvolvimento de agravos em uma população, no caso o AT, durante um intervalo de tempo determinado. Como uma proporção, a incidência acumulada é a razão entre duas quantidades, na qual o numerador está incluído no denominador (COSTA e KALE 2002). O cálculo da incidência foi possível, porque o evento de referência, o AT, é único, ou seja, ocorre somente uma vez. A mortalidade mediu o risco médio de um trabalhador sofrer um acidente fatal e a letalidade a probabilidade média de que o AT seja fatal. 
Neste estudo, utilizou-se como principal fonte de informação a base de dados da pesquisa realizada por convênio entre a Fundação Sistema Estadual de Análise de Dados - Seade e a Fundação Jorge Duprat Figueiredo de Segurança do Trabalho Fundacentro, com informações referentes aos ATs registrados no meio rural paulista entre 1997 e 1999.

\subsection{Universo de estudo}

Os registros de AT ocorridos em área rural e os referentes às culturas sucroalcooleira e cítrica, registrados junto à Previdência Social do Estado de São Paulo e coletados no projeto de pesquisa da Fundação Seade/Fundacentro.

\subsection{Período de referência}

A análise compreendeu o período entre 1 de janeiro de 1997 e 31 de dezembro de 1999. A coleta dos dados ocorreu entre outubro de 2000 e maio de 2001.

\subsection{Abrangência geográfica do estudo}

A extensão territorial desse levantamento compreendeu todo o Estado de São Paulo e contemplou todas as atividades desenvolvidas nas áreas rurais. A abrangência geográfica de todos os municípios paulistas possibilitou montar um perfil demográfico e epidemiológico da população trabalhadora assegurada (WALDVOGEL 2002), além de permitir verificar os diferenciais regionais dos ATs e proporcionar a elaboração de áreas especificas sobre a incidência destes.

\subsection{Fontes de dados}

\subsubsection{Principal fonte de informações}


A principal fonte de informações para a realização desse projeto foi a base de dados sobre AT da Fundação Seade/Fundacentro, que contém registros de acidentes ocorridos entre a população cadastrada junto à Previdência Social em área rural do Estado de São Paulo.

As informações presentes nessa base foram transcritas principalmente da Comunicação de Acidente do Trabalho - CAT e de outros documentos que pudessem acompanhar os respectivos processos, como Boletim de Ocorrência e o Atestado de Óbito.

Ao considerar outros documentos anexados ao processo, não só a CAT, tentou-se assegurar o preenchimento de todos os campos existentes no formulário de coleta (Anexo 1) e padronizar as informações, uma vez, que estas quando obtidas por meio de registros oficiais, costumam não seguir nenhuma padronização (PEREIRA 1995).

\subsubsection{Outras fontes utilizadas}

Este estudo também utiliza outras fontes de informações quantitativas, como:

- O Sensor Rural, da Fundação Seade, que se constitui de uma pesquisa quadrimestral da economia rural paulista, com questões relacionadas ao uso da terra, produção agrícola e atividades profissionais. As informações utilizadas são referentes a:

$\Rightarrow$ Estimativa da safra do ano por área cultivada (1.000 ha) segundo as principais culturas - Estado de São Paulo

$\Rightarrow$ Demanda de mão-de-obra pelas principais culturas do Estado de São Paulo

- O Censo Agropecuário de 1995/96, último censo realizado e divulgado específico a esse setor do Instituto Brasileiro de Geografia e Estatística - IBGE; com dados sobre a produção das lavouras permanentes e as lavouras temporárias, entre outras informações; 
$\Rightarrow$ Produção de lavoura temporária e permanente por área colhida (Hectare)

$\Rightarrow$ Produção das culturas de cana-de-açúcar e cítrica por área colhida (Hectare)

- A Pesquisa Nacional por Amostra de Domicílios - PNAD, do Instituto Brasileiro de Geografia e Estatística - IBGE.

$\Rightarrow$ Proporção da População Economicamente Ativa - PEA - residente em área rural por sexo

- O Censo Demográfico de 2000, Banco Multidimensional de Estatística do Instituto Brasileiro de Geografia e Estatística - IBGE.

$\Rightarrow$ Trabalho principal, setor de atividade

$\Rightarrow$ Trabalho principal, ocupação (Grupo 1 e Grupo 3)

$\Rightarrow$ Contribuição previdenciária

$\Rightarrow$ Sexo

$\Rightarrow$ Idade em anos

Todas essas fontes foram utilizadas com o intuito de caracterizar o painel sócio-demográfico da população em questão, exceção feita ao Censo Demográfico que também serviu de referência na obtenção dos denominadores da incidência e do coeficiente de mortalidade.

\subsection{Configuração do banco de dados Seade/Fundacentro}

Diante da dificuldade de obter informações relativas aos ATs, especificamente relacionados à população trabalhadora rural, verificando quais são as áreas de trabalho de maior risco de acidentes (DI SANTI 1994) e com o intuito de contribuir para a discussão dessa temática, foi realizado pela Fundação Sistema Estadual de Análise de Dados - Seade e a Fundação Jorge Duprat Figueiredo de Segurança do Trabalho - Fundacentro, um levantamento em todas as agências da 
Previdência Social no Estado de São Paulo, onde foram coletados, os ATs registrados em área rural no período compreendido entre 1997 e 1999.

Esse projeto de pesquisa utilizou esse banco de dados, cuja coleta contou com um grupo anteriormente treinado por meio de aulas que compreendiam noções básicas sobre o funcionamento da Previdência Social, leis referentes aos ATs e realização da coleta de dados, ministradas por profissionais de pesquisa e advogado. Também foram incluídas nesse treinamento visitas a agências $\mathrm{e}$ postos da Previdência Social.

A transcrição de dados da CAT foi realizada de forma manual em todas as agências e postos da Previdência Social no Estado por aproximadamente 30 pessoas distribuídas em seis grupos que percorreram todo o Estado.

As equipes eram formadas em sua grande parte por jovens estudantes. A seleção desses coletores foi firmada em suas experiências profissionais e formação escolar, foram priorizados os conhecimentos na área de pesquisa, noções de arquivo e de organização de documentos, além de letra legível e clara, pois não havia intenção de perder informações na transcrição da CAT.

Ao fim de cada dia, o responsável pela equipe conferia todos os formulários preenchidos pelo seu grupo de trabalho, caso houvesse algum com letra ilegível ou excesso de campos em branco, o formulário era separado e verificado novamente; se fosse problema de atenção ou letra ilegível do coletor, este refazia a coleta.

Essa busca ativa realizada de forma manual, constituiu-se no rastreamento de cada AT em todos os arquivos que pudessem conter CAT, onde eram selecionados os ATs correspondentes a um profissional de interesse, no conjunto de todos os casos de ATs existentes em cada agência e posto da Previdência Social (FUNDAÇÃO SEADE/FUNDACENTRO 2001). Isto foi executado com o intuito de identificar e qualificar o acidente a CAT, da Previdência Social. 
Além dos dados existentes na CAT, foram analisadas e passadas para o formulário especialmente criado (Anexo 1), todas as documentações que pudessem estar anexadas aos respectivos processos, como: laudo médico, boletim de ocorrência policial, certidão de óbito, certidão de casamento, xerox da carteira profissional, identidade, ou outros documentos que pudessem existir e servir de fonte de informação. A intenção era coletar o máximo de informações que pudessem fazer parte do AT e não estavam registradas na CAT por não estarem preenchidas com campos em branco ou não existentes.

Vale ressaltar que todas as agências e postos da Previdência Social, no Estado de São Paulo foram visitados e pesquisados por essas equipes treinadas para as atividades de identificação dos casos pertencentes ao universo da pesquisa e de avaliação dos documentos correspondentes aos ATs e para extrair informações relevantes ao preenchimento do formulário de coleta (FUNDAÇÃO SEADE/FUNDACENTRO 2001).

A seleção dos ATs rurais respondeu aos seguintes critérios:

- o acidente descrito no processo de AT ocorreu em área rural e foi um acidente de trajeto;

- o acidente descrito no processo de AT correspondeu a uma atividade de trabalho tipicamente rural.

Cada caso identificado foi coletado, levantando diversas características do acidentado (sexo, idade, estado civil, ocupação etc.); da empresa (Ramo de Atividade, município da empresa), do acidente (data, hora, tipo de acidente etc.), das circunstâncias do acidente (local, momento etc.), da relação do trabalho (aposentado, filiado à Previdência Social), epidemiológicas (partes do corpo atingidas, agente causador, diagnóstico médico), gravidade do acidente (sem afastamento, afastamento temporário, invalidez permanente e morte) (FUNDAÇÃO SEADE/FUNDACENTRO 2001). 
A coleta de informações sobre AT foi realizada em um momento de greve e no final do processo de reestruturação física das agências da Previdência Social, que passavam por padronização nacional, entretanto, não ocorreu nenhum contratempo que impedisse a coleta. Para tanto, foram realizadas várias negociações entre os gerentes das agências da Previdência Social e o próprio superintendente do INSS paulista, que já havia fornecido uma autorização por escrito. Dessa forma, as equipes tiveram acesso a todos os arquivos de documentação. Com o intuito de agilizar a coleta, foi permitida, inclusive, a entrada das equipes em agências fechadas aos sábados e feriados, além de estenderem suas atividades após o horário de funcionamento das agências.

Com receio de perder algum documento referente aos acidentes rurais do período de interesse, foi realizado um trabalho de conscientização junto a cada chefe das agências da Previdência Social, para que fossem investigados, além dos arquivos, pastas, postos de trabalho e gavetas que pudessem ter alguma informação de interesse à pesquisa. Vale ressaltar que as buscas nos lugares mais pessoais, como mesas e armários, eram realizadas, em geral, pelos seus respectivos usuários.

Deve ser salientado que a autora participou de toda a fase de coleta do dado, onde foi responsável por um grupo, que percorreu os municípios localizados no centro-oeste paulista até a região mais à oeste (de Bauru a Sertãozinho), assim como dos municípios que compõem a Baixada Santista.

Paralelo a essa etapa do trabalho, uma equipe de profissionais, que treinou e supervisionou os codificadores durante todo o processo, estava encarregada de elaborar listas de codificação para todas as variáveis levantadas. Com base nessa lista foram codificados todos os campos do formulário, digitando-os depois.

Foram criados códigos especificos para cada variável existente. Para a variável "ocupação", foram criados códigos especiais que contemplassem todos os profissionais. A variável "município" utilizou os códigos do IBGE. Para as variáveis, “descrição do acidente" (variável criada), "partes do corpo atingidas", foram criadas 
listas especiais procurando contemplar todo detalhamento disponivel (FUNDAÇÃO SEADE/FUNDACENTRO 2001).

3.6.1 Consolidação dos dados da pesquisa da Fundação Seade/Fundacentro

Os dados coletados passaram por um processo de crítica e revisão, realizado por uma equipe de supervisores. Em seguida foram efetuadas as etapas de codificação e digitação (SEADE/FUNDACENTRO, 2001).

Tanto a codificação como a digitação, sofreram várias etapas de consistência. Depois de codificado, cada campo era revisto por outro codificador que, no caso de dúvida, discutia o caso com o responsável pela supervisão. A digitação foi realizada em duas fases, nas quais os dados eram comparados e checados diariamente.

Após a etapa de consistência, os casos de ATs digitados foram organizados em um banco de dados (Access.mdb), que correspondia aos registros dos ATs efetuados nas agências e postos da Previdência Social localizados no Estado de São Paulo, relativos aos anos de 1997, 1998 e 1999.

Entre a transcrição dos dados a partir da CAT, codificação e entrada na base, decorreram algumas perdas. Inicialmente foram coletados 58.454 ATs. Destes registros, apenas 250 foram excluídos da base, dos quais 219 eram de acidentes-tipo, 24 de doenças do trabalho, cinco de acidente de trajeto e dois ignorados, ou seja, $0,4 \%$ da coleta.

\subsection{Configuração do banco de dados específico dessa pesquisa}


A partir da disponibilização da base de dados de registros de AT da Fundação Seade/Fundacentro descrita acima, iniciou-se a etapa de classificação dos ATs em culturas sucroalcooleira e de frutas citricas, com o objetivo de delimitar a população de interesse do presente trabalho.

\subsubsection{Elaboração das sub-bases estudadas}

Para a elaboração das sub-bases referentes aos registros de AT das culturas sucroalcooleiras e das frutas cítrica, foram realizadas as seguintes etapas.

Primeiro criou-se na base um novo campo de codificação, onde todos os eventos foram codificados, de acordo com o tipo de cultura, sendo que o número um classificava os eventos referentes às culturas sucroalcooleira, dois a cultura das frutas cítricas e três aos demais.

Para agrupar todos os eventos referentes a cada cultura foram utilizadas as variáveis: Classificação Nacional de Atividade Econômica - Ramo de Atividade, Ocupação, Municipio de ocorrência do acidente, Descrição do acidente e Agente causador. Esse tratamento possibilitou evitar algumas perdas, por estar um dos campos sem preencher ou por estarem preenchidos de forma ambígua. Para finalizar tal consolidação e assegurar essa classificação, foi averiguado junto ao Censo Agropecuário do IBGE, se os municípios apresentavam produção agrícola nestas culturas. Deve-se salientar que, para essa classificação, todos os eventos registrados foram analisados um a um, mais de uma vez.

Esse procedimento permitiu uma maior segurança na classificação dos registros de AT das culturas sucroalcooleiras e cítricas, sendo que todas as possibilidades de identificação de um AT ocorrido entre os trabalhadores envolvidos nessas culturas foram observadas. 
Para a consolidação do banco de dados específico dessa pesquisa, subdividido nas culturas sucroalcooleiras e cítricas, excluíram-se todos os registros cujo local de ocorrência do acidente não coincidia com a área de interesse deste estudo, ou seja, o Estado de São Paulo e os registros que tinham preenchido somente as variáveis: Número do Questionário; Local de Ocorrência (área Rural) e UF da Empresa, o que impossibilitava a análise estatística, por falta de informações.

Em razão do grande volume de registros que apresentavam o local de ocorrência do acidente classificado como "Ignorado", e interessadas em não perder informações, buscou-se averiguar através de outras variáveis informações que pudesse confirmar que os acidentes registrados tinham ocorrido dentro do território paulista.

Assim procedeu-se a averiguar outras variáveis que pudessem consolidar mais os dados, como a agência onde a CAT tinha sido notificada, o município de residência do acidentado e o município da empresa.

\subsection{Elaboração dos denominadores}

Delimitada a população de estudo e elaboradas as duas sub-bases de análise sucroalcooleira e cítrica, iniciou-se o processo de obtenção das distribuições de freqüências e considerando as variáveis selecionadas, assim como a busca pela população que serviu de denominador no cálculo dos indicadores propostos, tanto para a base-total como para a sucroalcooleira e cítrica.

Para a elaboração do denominador que expressasse o número de indivíduos efetivamente expostos ao risco de adoecer e/ou sofrer o AT dos grupos de trabalho analisados, empregaram-se as estimativas populacionais elaboradas por instituições governamentais como a Fundação Seade e o IBGE, comuns no âmbito dos serviços de saúde (COSTA e KALE, 2002). 
Diante da dificuldade e com o interesse que estes denominadores se aproximassem mais da população exposta aos AT observados e coletada por esse banco de dados, optou-se em utilizar a população já estimada pela Fundação Seade em idade ativa (de 10 a 69 anos), à qual foi aplicado um percentual resumido que correspondeu à proporção da população ocupada em atividades cujo trabalho principal estava ligado à área de interesse dessa pesquisa, contribuinte de Instituto de Previdência Oficial, em idade ativa por sexo, sob o total da população em idade ativa observada no Censo Demográfico de 2000.

A população utilizada foi a referida no meio do ano ( $\left(1^{\circ}\right.$ de julho), e esta estimativa corresponde ao tamanho médio da população e a quantidade de pessoasano acumulada (COSTA e KALE 2002).

A estimativa populacional da Fundação Seade é realizada através do Método dos Componentes Demográficos. A população estimada para $1^{\circ}$ de julho foi calculada com base nos dados do Censo Demográfico do Estado de São Paulo - IBGE e no crescimento vegetativo e migratório a partir das Estatisticas Vitais produzidas por esta Instituição. Esse cálculo é realizado para cada município específico (FUNDAÇÃO SEADE 2004; WALDVOGEL 1990).

O método adotado pelo IBGE para estimar a população dos municípios brasileiros é o Apportionment Method - conhecido no Brasil como "método dos coeficientes" ou AiBi. Esse método matemático considera a tendência de crescimento populacional do município entre dois censos demográficos consecutivos, em relação à mesma tendência de uma área geográfica maior (WALDVOGEL 1990). O cálculo desse método também requer uma projeção populacional, que considera a evolução dos componentes demográficos (fecundidade, mortalidade e migração), só que para uma área maior que o município, ou seja, a estimativa da população municipal, nesse caso, estaria atrelada à dinâmica demográfica de uma Unidade da Federação, País ou Região (IBGE 2004). 
Por levar em consideração a interação dos componentes demográficos (fecundidade, mortalidade e migração), responsáveis pelo crescimento populacional, optou-se em utilizar as estimativas populacionais da Fundação Seade, que devido ao tratamento específico dado a cada área (município), proporcionam uma estimativa mais próxima da realidade (FUNDAÇÃO SEADE 2004).

As estimativas populacionais para um determinado local e ano elaboradas por instituições governamentais como a Fundação Seade ou o IBGE, são utilizadas como expressão da quantidade de pessoas-tempo sob risco. É o caso das análises em que não se dispõem de informações no nível individual, mas somente com relação a grupos, ou agregados populacionais comuns no âmbito dos serviços de saúde (COSTA E KALE 2002).

Para obtenção destes denominadores, utilizou-se o Banco Multidimensional de Estatística - BME do IBGE, disponível no site dessa instituição através de assinatura. Esse banco contém todas as variáveis referentes ao universo e a amostra do Censo Demográfico de 2000 (IBGE 2002).

As informações referentes aos microdados da amostra selecionados foram as Variáveis:

* Características pessoais:

- Sexo da pessoa - V0401 - masculino/feminino

- Idade e anos, classe - V0405/ V0406/ V0407 (V4752a) - idade da pessoa em anos completos na data de referência da pesquisa, em classes de valores. Iniciada em zero até 100 anos em mais, em grupos qüinqüenais.

* Trabalho e rendimento:

- Contribuição previdenciária - V0450 
Este quesito se refere a pessoa contribuinte de instituto de previdência, seja este, instituto de previdência público, como o Instituto Nacional de Seguridade Social - INSS, Plano de Seguro Social da União, e Institutos de Previdência Social Estaduais ou Municipais ou das Forças Armadas e das Forças Auxiliares.

Com o intuito de refinar a informação foram selecionados as respostas classificadas em Sim, carteira assinada e Sim, demais situações, dessa forma os militares e os trabalhadores vinculados ao RJU - Regime Jurídico dos Funcionários Públicos foram excluídos.

Com relação ao trabalho principal foram utilizados para as sub-bases sucroalcooleira e cítrica as seguintes variáveis presentes no BME:

- Trabalho principal, ocupação, grupo(1) - V0445 (V4452b), técnicos da produção agropecuária, produtores agrícolas, trabalhadores agricolas, trabalhadores da mecanização agropecuária, condutores veículos e operadores de equipamentos elevação de carga, trabalhadores agroindústria de fabricação de alimentos e bebidas (inclusive artesanais), produtores agropecuários em geral, trabalhadores na exploração agropecuária em geral, supervisores na exploração agropecuária e ocupação mal especificada.

- Trabalho principal, setor de atividade - V0446 (V4462a) - referente ao cultivo de cana-de-açúcar e cultivo de frutas cítricas.

Ainda com relação ao trabalho principal, mas para o cálculo dos indicadores de toda a base, onde estão presentes todos os trabalhadores da área rural, foi utilizada a variável:

- Trabalho principal, ocupação, grupo (3) - V0445 (V4452d) -, trabalhos agropecuários, florestais, caça e pesca.

O universo ocupacional compreendido neste grupo corresponde às grandes áreas do emprego do setor primário. Os trabalhadores aqui reunidos têm por 
incumbência executar as tarefas próprias da agricultura, pecuária, exploração florestal e pesca, bem como operar os equipamentos utilizados nessas atividades. Este grande grupo reúne tanto os trabalhadores ligados diretamente à produção de bens primários, como aqueles que participam da administração direta de unidades produtivas agricolas.

\subsection{Tratamento e análise dos dados}

Definidas as variáveis de estudo, processou-se a recodificação da variável denominada Faixa Etária. Essa informação se encontrava na base original da Fundação Seade/Fundacentro disponível em idade simples. Antes de recodificá-la, esta foi conferida pela data de nascimento do acidentado, também disponível nesta base.

3.9.1 Variáveis selecionadas para a realização das frequeências

As variáveis selecionadas para serem analisadas com o intuito de caracterizar os ATs foram:

- Sexo

Masculino

Feminino

Ignorado

- Faixa Etária: em anos simples será trabalhada segundo as faixas etárias qüinqüenais.

De 10 a 14 anos
De 15 a 19 anos
De 20 a 24 anos
De 25 a 29 anos
De 30 a 34 anos
De 35 a 39 anos
De 40 a 44 anos
De 45 a 49 anos
De 50 a 54 anos 


\begin{abstract}
De 55 a 59 anos
De 60 a 64 anos

De 65 a 69 anos

De 70 a 74 anos

De 75 anos e mais

Ignorada
\end{abstract}

A classificação qüinqüenal adotada nesse trabalho seguiu a convenção que se inicia em zero. Usualmente utiliza-se o agrupamento qüinqüenal ou decenal (intervalo de tempo em que são publicados os Censos e PNADs), porque além de facilitar a visualização gráfica, corrige a atração pelos dígitos zero e cinco.

Com exceção de trabalhos específicos que fazem uso de outros cortes etários ou por idade simples, a grande maioria das análises demográficas utiliza grupos qüinqüenais iniciados em zero, o que torna os trabalhos comparáveis.

Essas faixas etárias foram selecionadas porque englobam todas as idades observadas na base de dados de AT da Seade/Fundacentro. Além dessas faixas qüinqüenais, foi analisada a idade menor de 18 anos, incluindo a de 14 a 18 anos incompletos que corresponde ao aprendiz, com o intuito de verificar o que acontece nesse grupo de jovens.

- Tipo de Acidente - variável numérica - classificada em:

- Acidente tipo;

- Acidente de trajeto e

- Doença do trabalho.

- Conseqüência do Acidente - variável numérica - classificada segundo:

- Incapacidade Temporária (acidentes que geraram afastamento do trabalho e que se dividem em menos de 15 dias e mais de 15 dias);

- Incapacidade Permanente ou Invalidez (acidentes que geraram invalidez permanente); $\mathrm{e}$ 
- Óbito (acidentes fatais).

- Partes do Corpo Atingidas - variável texto - classificada segundo a parte do corpo atingida no acidente. Essa variável foi agrupada em grandes grupos.

- Membros inferiores (quadril, coxa, joelho, perna, tornozelo, pé (dedos));

- Membros superiores (ombro, braço, cotovelo, antebraço, mão (dedos));

- Tronco;

- Cabeça (olhos, ouvidos) e

- Ignorado.

Esse agrupamento foi realizado com assessoria médica, que identificou todas as partes do corpo atingidas e as reuniu, conforme sua localização nas grandes divisões anatômicas.

- Ocupação - variável texto.

Classificação das categorias profissionais presentes na CAT dos trabalhadores das culturas sucroalcooleiras e citricas.

- Descrição do Acidente variável texto.

Elaborada pela Fundação Seade, para referir aspectos do processo causal, essa variável foi obtida através de uma codificação especial criada por esta Instituição, a partir do campo referente à Descrição da situação geradora do acidente ou doença (transcrita da CAT).

Como referência inicial foi utilizada a Classificação Internacional de Doenças CID da Organização Mundial da Saúde - OMS, que apresenta uma codificação internacional das causas de mortalidade e morbidade. Os códigos empregados referem-se ao capitulo XX de Causas Externas de Morbidade e de Mortalidade 
(V01-Y98), que possibilita classificar as ocorrências e circunstâncias ambientais como a causa de lesões, envenenamento e outros efeitos adversos.

Estes códigos foram ampliados de acordo como o detalhamento encontrado no campo existente na CAT, Descrição da situação geradora do acidente ou doença, com 0 intuito de identificar e detalhar todas as informações encontradas. Essa classificação especial compreendeu a 314 códigos, que se encontra em anexo (Anexo 3).

3.9.2 Elaboração das freqüências segundo as variáveis selecionadas

A análise das freqüências e cruzamentos entre as variáveis selecionadas desses bancos de dados proporciona uma descrição dos ATs registrados entre 1997 e 1999 para a população trabalhadora referente às categorias profissionais relacionadas ao corte da cana e a colheita das frutas cítricas do Estado de São Paulo, cadastrada junto ao Instituto de Previdência Social.

As variáveis selecionadas permitiram conhecer:

- Tipo de acidente por ano e cultura;

- Conseqüência por ano e cultura;

- Tipo de acidente segundo conseqüência e ano para as culturas sucroalcooleiras e cítrica;

- Sexo do acidentado por ano e cultura;

- Tipo de acidente segundo sexo e ano para as culturas sucroalcooleiras e cítrica;

- Faixa etária por ano segundo a cultura;

- Menores de 18 anos segundo a cultura;

- Partes do corpo por sexo e tipo de acidente, segundo a cultura e

- Ocupação por ano e cultura.

- Descrição do acidente e da doença por ano e cultura

\subsubsection{Cálculo dos indicadores}


Para mensurar a freqüência dos ATs foi calculada, como já citado, a incidência acumulada, onde se relaciona a acumulação de casos novos registrados ou iniciados em um periodo de tempo determinado, ou seja, os casos de AT registrados em cada ano de interesse, com a população de onde provieram os acidentados em um dado período de tempo (LAURENTI 1980; CORRÊA FILHO 1994b). Dessa forma, relacionaram-se os ATs segundo a residência do acidentado com a população residente destes municipios segundo sua inserção no trabalho agrícola, população esta obtida pelo BME.

O coeficiente, por sua vez, é uma freqüência de eventos que ocorreram em um dado período do tempo dividida pela população aferida na metade do período de tempo estipulado.

Pelo cálculo da incidência é possivel comparar regionalmente as estimativas de riscos que as distintas populações têm de registrar um AT ou mesmo ver como varia e se varia em períodos distintos de anos, nessa mesma população (LAURENTI 1980).

Assim, os numeradores desses coeficientes são os ATs obtidos segundo a residência do acidentado e registrados no ano, enquanto os denominadores são compostos pela população correspondente a esse mesmo ano, em idade ativa (de 10 a 69 anos), sexo, ocupada em atividades agropecuária e contribuinte de Instituto de Previdência Oficial.

O cálculo da incidência acumulada dos registros do meio rural, das culturas sucroalcooleira e das frutas cítricas será:

Incidência $=$ $N^{\circ}$ de registros de AT rurais no ano $X$ $* 1.000$

Acumulada Pop. meio do ano $\mathrm{X}$ de 10-69 anos, ocupada em atividades rurais e contribuinte de Instituto de Previdência Oficial

Incidência $=\mathrm{N}^{\circ}$ de registros de AT do cultivo da cana-de-acúcar no ano $\mathrm{X}$ 
Acumulada Pop. meio do ano X de 10-69 anos, ocupada no cultivo da cana-de-açúcar e contribuinte de Instituto de Previdência Oficial

Incidência $=\mathrm{N}^{0}$ de registros de AT do cultivo de frutas cítricas no ano $\mathrm{X}$ _ 1.000 Acumulada Pop. meio do ano X de 10-69 anos, ocupada no cultivo de frutas cítricas e contribuinte de Instituto de Previdência Oficial

No caso do coeficiente de mortalidade, o numerador é a população por sexo que sofreu um AT registrado e veio a falecer em decorrência desse, com óbito de origem ocupacional registrado pela Previdência Social. Enquanto comporá o denominador a população exposta, que corresponderá à população por sexo de 10 a 69 anos, ocupada em atividades agropecuária e contribuinte de um Instituto de Previdência Social entre 1997 e 1999.

Mortalidade $=\underline{N^{\circ} \text { de registros de óbitos por AT rural no ano X }} * 1.000$

Pop. meio do ano $X$ de 10-69 anos, ocupada em atividades rurais e contribuinte de

Instituto de Previdência Oficial

Mortalidade $=\underline{\mathrm{N}^{0} \text { de registros de ób. por AT do cultivo da cana-de-acúcar no ano } \mathrm{X}} * 1.000$

Pop. meio do ano $X$ de 10-69 anos, ocupada no cultivo da cana-de-açúcar e contribuintes de Instituto de Previdência Oficial

Mortalidade $=\underline{\mathrm{N}^{\circ} \text { de registros de ób. por AT do cultivo das frutas cítricas no ano } \mathrm{X}} * 1.000$

Pop. meio do ano $X$ de $10-69$ anos, ocupada no cultivo das frutas citricas e contribuinte de Instituto de Previdência Oficial

Esse denominador foi escolhido, por ser o que mais se aproxima da populą̧ão coberta pelo INSS e exposta a sofrer algum tipo de AT (WALDVOGEL 2002). 
As medidas de gravidade foram calculadas pelo coeficiente de letalidade, a mais usada na epidemiologia (LAURENTI 1980) que corresponde ao número de óbitos da doença (acidente) pelo número de casos que ocorreram dessa mesma doença ou acidente. Tanto o numerador como denominador encontram-se disponíveis na base de dados sobre AT da Fundação Seade/Fundacentro.

Calculadas para os ATs registrados no meio rural contido na base de dados e para aqueles trabalhadores envolvidos no cultivo da cana-de-açúcar e das frutas cítrica, no periodo de 1997 a 1999.

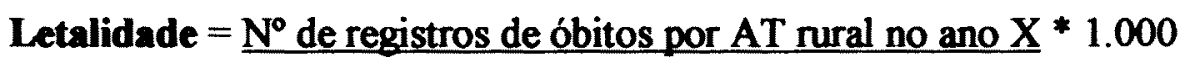

$\mathrm{N}^{\circ}$ de registro de $\mathrm{AT}$ rural no ano $\mathrm{X}$

Letalidade $=\mathrm{N}^{\circ}$ de registros de ob. por AT do cultivo da cana-de-acúcar no ano $\mathrm{X} * 1.000$

$\mathrm{N}^{\circ}$ de registro de $\mathrm{AT}$ do cultivo da cana-de-açúcar no ano $\mathrm{X}$

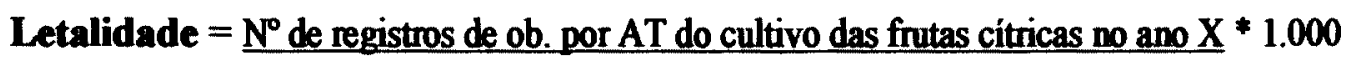

$\mathrm{N}^{\circ}$ de registro de AT do cultivo das frutas cítricas no ano $\mathrm{X}$

Tentando solucionar o problema dos pequenos números, optou-se em agrupar os municípios conforme o valor observado no denominador e no numerador, assim, os requisitos estipulados, para o cálculo desses indicadores em áreas menores, são: no denominador, população definida superior a 10 mil habitantes, e no numerador o limite mínimo de 20 casos de registros de AT. Se isso não ocorresse os dados referentes ao município eram obrigatoriamente somados com outros. Para a elaboração dessas áreas foram considerados todos os municípios que registraram AT junto a Previdência Social, como também os municípios que contavam com trabalhadores residentes envolvidos em atividades rurais e/ou nas culturas sucroalcooleiras e cítrica (obtidas através do BME), conforme o interesse, mesmo que estes não apresentassem nenhuma notificação de AT. Os municípios que não cumpriam esse critério eram descartados. 
O agrupamento dos municípios, além de ser uma tentativa de tornar os índices mais robustos, tentou "melhorar" as possíveis distorções decorrentes do fato da população rural que trabalha no campo residir em um município e, em alguns casos, trabalhar em outro. Considerando-se que o município de residência situa-se próximo ao local de trabalho optou-se por um cálculo numa área maior.

Como já explicitado, nesse projeto também foram calculados os coeficientes de mortalidade e de letalidade, que são indicadores de interesse especial para a área de saúde do trabalhador, assim como a incidência acumulada, a qual o Ministério do Trabalho e Emprego utiliza no estabelecimento de ações de controle (MTE 2004).

Outros indicadores divulgados pela Previdência Social, como Índice de Freqüência, Índice de Gravidade e Índice de Custo ${ }^{10}$, que visam medir os acidentes que geraram beneficios, dias perdidos e gastos de interesse dessa instituição, não foram calculados.

A ferramenta eletrônica utilizada para obter o conjunto de tabulações de interesse foi o programa Microsoft Access 97. Para calcular a incidência e os coeficientes de mortalidade e letalidade se utilizou a planilha eletrônica Excel. A base de dados está disponível em banco de dados Access.mdb.

\footnotetext{
${ }^{10}$ Índice de Frequiência: If $=$ Número Total de AT que Geraram Beneficios $* 1.000 .000$ Homens-Hora-Trabalhadas

Índice de Gravidade Ig $=$ Número Total de Dias Perdidos *1.000 Homens-Hora-Trabalhadas

Índice de Custo Ic $=$ Gastos com Pagamento de Beneficios por AT $* 100$

Contribuiçåo Total das Empresas
} 


\section{RESULTADOS}

\subsection{Consolidação do banco de dados específico dessa pesquisa}

No transcorrer da análise para a construção das sub-bases: sucroalcooleira e cítrica, foram excluídos todos os registros cujos locais de ocorrência dos acidentes não coincidiam com a área de interesse deste estudo, ou seja, o Estado de São Paulo, o que correspondeu a 355 acidentes ocorridos fora desta Unidade da Federação e mais dois registros, preenchidos somente com o Número do Questionário, Local de Ocorrência (área Rural) e UF da Empresa, o que impossibilitava a análise estatística, por falta de informações. Dessa forma, as perdas totais, nessa fase, perfizeram um total de 357 registros, ou seja, $0,58 \%$ dos registros de AT contidos na base Seade/Fundacentro.

Em razão do grande volume de registros cujo município de ocorrência do AT era ignorado (16.182), buscou-se averiguar por outras variáveis informações que pudessem confirmar que os acidentes registrados tinham ocorrido dentro do território paulista, o intuito desse procedimento era não perder nenhum registro de AT.

Assim se procedeu na averiguação de outras variáveis que pudessem consolidar mais os dados, como a agência onde a CAT tinha sido notificada, o município de residência do acidentado e o município da empresa. A freqüência por agência que não preencheu de forma adequada este campo da CAT, estavam distribuídas por todo o Estado, sendo as mais relevantes: Ribeirão Preto, Araraquara, Bauru e São João da Boa Vista, que concentravam cerca de $77 \%$ dos destes registros.

Destes registros, 98,7\% eram de acidentes cujo endereço da Prestadora de Serviço (Empresa/Fazenda) situava-se no Estado de São Paulo, e 90,4\% eram de trabalhadores que declararam residir em algum município de São Paulo. 
Aceitou-se esses ignorados como sendo ocomidos no Estado de São Paulo, devido a alta proporção de registros de AT cujos endereços das Prestadoras de Serviços (Empresa/Fazenda) situavam-se no Estado de São Paulo (98,7\%), assim como de trabalhadores que declararam residir em algum municipio de São Paulo $(90,4 \%)$.

\subsection{Descrição das variáveis}

4.2.1 Distribuição dos registros de AT por tipo de acidente

Em um universo total de 57.867 registros de AT em áreas rurais, levantado junto a CAT, em todas as agências da Previdência Social do Estado de São Paulo pela Fundação Seade/Fundacentro, observa-se entre 1997 e 1999 uma queda de cerca de $20 \%$ destes registros, passando de 21.166 para 16.850 , respectivamente. Destes a grande maioria é composta por acidentes-tipo, que nos três anos analisados perfizeram cerca de $90 \%$ de todos os acidentes registrados. Com menores participações, encontram-se as doenças do trabalho que variaram entre $8 \%$ a $11 \%$ dos eventos registrados e por último os acidentes de trajeto, o qual em nenhum dos anos em questão alcançou o patamar dos $2 \%$ (Tabela 2). Inversamente a esta queda, os registros de AT referentes às culturas sucroalcooleiras e cítricas apresentaram crescimento entre 1997 e 1999.

Com $43 \%$ dos acidentes registrados nesse período, a cultura sucroalcooleira contabilizou um aumento de $4 \%$ nesse intervalo de tempo, passando de 8.186 registros de AT para 8.517. Entre estes, predominam, com $83 \%$ a $90 \%$ dos registros, os acidentes decorrentes da atividade profissional desempenhada pelo trabalhador, ou seja, os acidentes-tipo. Com proporções menos relevantes encontram-se os acidentes de trajeto e as doenças do trabalho. Esta última mostrou uma tendência de queda, com uma pequena recuperação no último ano (Tabela 2). 
Numericamente inferiores e com uma menor participação no total dos ATs registrados em área rural entre 1997 e 1999, a cultura das frutas cítricas também mostrou crescimento no período. Mais expressivo, o aumento de cerca de $44 \%$ significou um acréscimo de 264 registros de acidentes no período que, de 602 passaram para 866 , ao final do intervalo (Tabela 2 ).

Tabela 2

Número e Proporção dos Registros de AT em Áreas Rurais, nas Culturas Sucroalcooleira e das Frutas Cítricas, segundo Ano e Tipo do AT. Estado de São Paulo.

1997,1998 e 1999

\begin{tabular}{|c|c|c|c|c|c|c|}
\hline \multirow{3}{*}{$\begin{array}{c}\text { Tipo do } \\
\text { Acidente do } \\
\text { Trabalho } \\
\end{array}$} & \multicolumn{6}{|c|}{ Ano do AT } \\
\hline & \multicolumn{2}{|c|}{1997} & \multicolumn{2}{|c|}{1998} & \multicolumn{2}{|c|}{1999} \\
\hline & $\mathrm{N}^{\circ}$ & $\%$ & $\mathbf{N}^{\circ}$ & $\%$ & $N^{0}$ & $\%$ \\
\hline & \multicolumn{6}{|c|}{ Área Rural (*) } \\
\hline Acidente-Tipo & 18.451 & 87,17 & 17.880 & 90,07 & 15.052 & 89,33 \\
\hline Acidente de Trajeto & 319 & 1,51 & 315 & 1,59 & 290 & 1,72 \\
\hline Doença de Trabalho & 2.281 & 10,78 & 1.570 & 7,91 & 1.436 & 8,52 \\
\hline Ignorado & 115 & 0,54 & 86 & 0,43 & 72 & 0,43 \\
\hline \multirow[t]{2}{*}{ Total } & 21.166 & 100,00 & 19.851 & 100,00 & 16.850 & 100,00 \\
\hline & \multicolumn{6}{|c|}{ Cultura Sucroalcooleira } \\
\hline Acidente-Tipo & 6.828 & 83,41 & 7.269 & 89,30 & 7.603 & 89,27 \\
\hline Acidente de Trajeto & 106 & 1,29 & 124 & 1,52 & 158 & 1,86 \\
\hline Doença de Trabalho & 1.217 & 14,87 & 724 & 8,89 & 730 & 8,57 \\
\hline Ignorado & 35 & 0,43 & 23 & 0,28 & 26 & 0,31 \\
\hline \multirow[t]{2}{*}{ Total } & 8.186 & 100,00 & 8.140 & 100,00 & 8.517 & 100,00 \\
\hline & \multicolumn{6}{|c|}{ Cultura das Frutas Cítricas } \\
\hline Acidente-Tipo & 552 & 91,69 & 576 & 93,35 & 797 & 92,03 \\
\hline Acidente de Trajeto & 9 & 1,50 & 19 & 3,08 & 18 & 2,08 \\
\hline Doença de Trabalho & 39 & 6,48 & 20 & 3,24 & 48 & 5,54 \\
\hline Ignorado & 2 & 0,33 & 2 & 0,32 & 3 & 0,35 \\
\hline Total & 602 & 100,00 & 617 & 100,00 & 866 & 100,00 \\
\hline
\end{tabular}

Nota: $\left(^{*}\right)$ Inclui todos os registros existentes na Base de AT no Meio Rural.

Não divergindo da cultura sucroalcooleira e dos acidentes em área rural, a cultura cítrica também se caracteriza por uma alta proporção de acidentes-tipo, 
superior a $90 \%$ no decorrer dos anos e com reduzida presença dos acidentes de trajeto e das doenças do trabalho. Vale ressaltar, a participação dos acidentes de trajeto em 1998, que proporcionalmente se aproximaram das doenças do trabalho (Tabela 2).

4.2.2 Distribuição dos registros de AT segundo a conseqüência do acidente

Os registros de AT observados nessa base de dados mostram a incapacidade temporária (período que afasta o trabalhador por um tempo limitado, que pode ser superior ou inferior a 15 dias, retornando em seguida às suas atividades normais) como a principal conseqüência do AT, tanto para todos os registros de acidentes em área rural, como para aqueles transcritos para as culturas sucroalcooleira e cítrica.

Tabela 3

Número e Proporçao dos Registros de Acidentes do Trabalho em Áreas Rurais, nas Culturas Sucroalcoolei e das Frutas Cítricas, segundo Ano e Consequência do Acidente do Trabalho

Estado de São Paulo. 1997, 1998 e 1999

\begin{tabular}{|c|c|c|c|c|c|c|}
\hline \multirow{3}{*}{$\begin{array}{c}\text { Consequência } \\
\text { do Acidente } \\
\text { do Trabalho }\end{array}$} & \multicolumn{6}{|c|}{ Ano do Acidente do Trabalho } \\
\hline & \multicolumn{2}{|c|}{1997} & \multicolumn{2}{|c|}{1998} & \multicolumn{2}{|c|}{1999} \\
\hline & No. & $\%$ & No. & $\%$ & No. & $\%$ \\
\hline & \multicolumn{6}{|c|}{ Area Rural (*) } \\
\hline Óbito & 39 & 0,18 & 22 & 0,11 & 25 & 0,15 \\
\hline Incapacid ade Permanente & 27 & 0,13 & 17 & 0,09 & 20 & 0,12 \\
\hline Incapacidade Temporária & 21.100 & 99,69 & 19.812 & 99,80 & 16.805 & 99,73 \\
\hline \multirow[t]{2}{*}{ Total } & 21.166 & 100,00 & 19.851 & 100,00 & 16.850 & 100,00 \\
\hline & \multicolumn{6}{|c|}{ Cultura Sucroslcooleira } \\
\hline Óbito & 6 & 0,07 & 5 & 0,06 & 7 & 0,08 \\
\hline Incapacidade Permanente & 3 & 0,04 & 3 & 0,04 & 5 & 0,06 \\
\hline Incapacidade Temporária & 8.177 & 99,89 & 8.132 & 99,90 & 8.505 & 99,86 \\
\hline \multirow[t]{2}{*}{ Total } & 8.186 & 100,00 & 8.140 & 100,00 & 8.517 & 100,00 \\
\hline & \multicolumn{6}{|c|}{ Cultura das Frutas Citricas } \\
\hline Óbito & 1 & 0,17 & 2 & 0,32 & - & - \\
\hline Incapacidade Permanente & 1 & 0,17 & 1 & 0,16 & 2 & 0,23 \\
\hline Incapacidade Temporária & 600 & 99,67 & 614 & 99,51 & 864 & 99,77 \\
\hline Total & 602 & 100,00 & 617 & 100,00 & 866 & 100,00 \\
\hline
\end{tabular}

Nota: $\left(^{*}\right)$ Inclui todos os registros existentes na Base de Acidentes do Trabalho no Meio Rural 
Na observação dos registros para todos os ATs no meio rural entre 1997 e 1999, como também para as culturas sucroalcooleira e cítrica ano a ano, nota-se que a incapacidade temporária alcança, em todos os casos, um pouco mais de $99 \%$ dos registros de AT (Tabela 3).

A incapacidade permanente e os óbitos juntos não compreendem a 15 dos AT registrados para nenhuma das culturas analisadas e nem para o total dos registros de acidentes do meio rural paulista.

4.2.3 Distribuição dos Registros de AT das culturas sucroalcooleiras e cítrica segundo tipo e conseqüência

No cruzamento realizado entre tipo de acidente e conseqüência para as culturas sucroalcooleiras e cítricas, nota-se que a incapacidade temporária apresenta predomínio para os acidentes-tipo, de trajeto e doenças do trabalho, enquanto a incapacidade permanente e os óbitos atingiriam uma parcela bastante reduzida.

Quanto aos acidentes-tipo, nota-se que tanto a cultura sucroalcooleira como a cítrica apresentam o mesmo perfil, onde a incapacidade temporária proporcionalmente ultrapassava $99 \%$ dos registros de AT, enquanto os óbitos e a incapacidade permanente, juntas não alcançam $1 \%$ desses acidentes (Tabela 4).

Com menor participação no total dos registros de AT, os acidentes de trajeto, apresentaram óbitos em 1997 e 1999 somente na cultura sucroalcooleira.

Em relação aos acidentes-tipo, os acidentes de trajeto das culturas sucroalcooleiras, proporcionalmente resultaram mais em óbitos, apesar de numericamente inferiores (Tabela 4).

As doenças do trabalho resultaram, praticamente em sua totalidade, em incapacidade temporária, somente em 1998 para a cultura sucroalcooleira ocorreu um 
único evento que se reverteu numa incapacidade permanente. Em nenhuma das culturas analisadas, as doenças do trabalho resultou em um registro de óbito por AT.

Tabela 4

Distribuição dos Registros de Acidentes do Trabalho nas Culturas Sucroalcooleiras e das Frutas Cítricas, por Tipo de AT e Consequência do Acidente. Estado de São Paulo. 1997, 1998 e 1999

\begin{tabular}{|c|c|c|c|c|c|c|c|c|}
\hline \multirow{2}{*}{$\begin{array}{c}\text { Consequiencia } \\
\text { do AT }\end{array}$} & \multicolumn{2}{|c|}{ Acidente-Tipo } & \multicolumn{2}{|c|}{ Acidente de Trajeto } & \multicolumn{2}{|c|}{ Doença de Trabalho } & \multicolumn{2}{|c|}{ Total (**) } \\
\hline & No. & $\%$ & No. & $\%$ & No. & $\%$ & No. & $\%$ \\
\hline & \multicolumn{8}{|c|}{ Cultura Sucroalcooleira } \\
\hline & \multicolumn{8}{|c|}{1997} \\
\hline Óbito & 5 & 0,07 & 1 & 0,94 & - & - & 6 & 0,07 \\
\hline Incapacidade Permanente & 3 & 0,04 & - & - & - & - & 3 & 0,04 \\
\hline Incapacidade Temporária & 6.820 & 99,88 & 105 & 99,06 & 1.217 & 100,00 & 8.177 & 99,89 \\
\hline \multirow[t]{2}{*}{ Total } & 6.828 & 100,00 & 106 & 100,00 & 1.217 & 100,00 & 8.186 & 100,00 \\
\hline & \multicolumn{8}{|c|}{1998} \\
\hline Óbito & 4 & 0,06 & - & - & - & - & 5 & 0,06 \\
\hline Incapacidade Permanente & 2 & 0,03 & - & - & 1 & 0,14 & 3 & 0,04 \\
\hline Incapacidade Temporária & 7263 & 99,92 & 124 & 100,00 & 723 & 99,86 & 8.132 & 99,90 \\
\hline \multirow[t]{2}{*}{ Total } & 7.269 & 100,00 & 124 & 100,00 & 724 & 100,00 & 8.140 & 100,00 \\
\hline & \multicolumn{8}{|c|}{1999} \\
\hline Óbito & 6 & 0,08 & 1 & 0,63 & - & - & 7 & 0,08 \\
\hline Incapacidade Permanente & 5 & 0,07 & - & - & - & - & 5 & 0,06 \\
\hline Incapacidade Temporária & 7592 & 99,86 & 157 & 99,37 & 730 & 100,00 & 8.505 & 99,86 \\
\hline \multirow[t]{3}{*}{ Total } & 7.603 & 100,00 & 158 & 100,00 & 730 & 100,00 & $\mathbf{8 . 5 1 7}$ & 100,00 \\
\hline & \multicolumn{8}{|c|}{ Cultura de Frutas Cítricas } \\
\hline & \multicolumn{8}{|c|}{1997} \\
\hline Óbito & 1 & 0,18 & - & - & - & - & 1 & 0,17 \\
\hline Incapacidade Permanente & 1 & 0,18 & - & - & - & - & 1 & 0,17 \\
\hline Incapacidade Temporária & 550 & 99,64 & 9 & 100,00 & 39 & 100,00 & 600 & 99,67 \\
\hline \multirow[t]{2}{*}{ Total } & $\mathbf{5 5 2}$ & 100,00 & 9 & 100,00 & 39 & 100,00 & 602 & 100,00 \\
\hline & \multicolumn{8}{|c|}{1998} \\
\hline Óbito & 2 & 0,35 & - & - & - & - & 2 & 0,32 \\
\hline Incapacidade Permanente & 1 & 0,17 & - & - & - & - & 1 & 0,16 \\
\hline Incapacidade Temporária & 573 & 99,48 & 19 & 100,00 & 20 & 100,00 & 614 & 99,51 \\
\hline \multirow[t]{2}{*}{ Total } & 576 & 100,00 & 19 & 100,00 & 20 & 100,00 & 617 & 100,00 \\
\hline & \multicolumn{8}{|c|}{1999} \\
\hline Óbito & - & - & - & - & - & - & - & - \\
\hline Incapacidade Permanente & 2 & 0,25 & - & - & - & - & 2 & 0,23 \\
\hline Incapacidade Temporária & 795 & 99,75 & 18 & 100,00 & 48 & 100,00 & 864 & 99,77 \\
\hline Total & 797 & 100,00 & 18 & 100,00 & 48 & 100,00 & 866 & 100,00 \\
\hline
\end{tabular}

Nota: $\left(^{*}\right)$ Inclui os acidentes cujo a consequencia do AT era ignorada

(-) Fenômeno inexistente. 
4.2.4 Distribuição dos registros de AT segundo o sexo do acidentado

Na distribuição segundo o sexo do acidentado constante dos registros de AT, evidencia-se a representatividade do sexo masculino em todo o período, estudados para as culturas selecionadas como para todos os eventos registrados.

Observa-se, para o total dos acidentes registrados no meio rural, uma proporção que pouco variou durante o periodo de $10,9 \%$ a $10,3 \%$ de participação feminina no total de registros de AT por ano (Tabela 5).

Tabela 5

Número e Proporção dos Registros de Acidentes do Trabalho em Áreas Rurais, nas Culturas Sucroalcooleira e das Frutas Cítricas, segundo Ano e Sexo do Acidentado do Trabalho Estado de São Paulo . 1997, 1998 e 1999

\begin{tabular}{|c|c|c|c|c|c|c|}
\hline \multirow{3}{*}{$\begin{array}{c}\text { Sexo } \\
\text { do } \\
\text { Acidentado } \\
\end{array}$} & \multicolumn{6}{|c|}{ Ano do Acidente do Trabalho } \\
\hline & \multicolumn{2}{|c|}{1997} & \multicolumn{2}{|c|}{1998} & \multicolumn{2}{|c|}{1999} \\
\hline & No. & $\%$ & No. & $\%$ & No. & $\%$ \\
\hline & \multicolumn{6}{|c|}{ Área Rural $(*)(* *)$} \\
\hline Masculino & 18.862 & 89,11 & 17.774 & 89,54 & 15.106 & 89,65 \\
\hline Feminino & 2.303 & 10,88 & 2.077 & 10,46 & 1.744 & 10,35 \\
\hline \multirow[t]{2}{*}{ Total } & 21.166 & 100,00 & 19.851 & 100,00 & 16.850 & 100,00 \\
\hline & \multicolumn{6}{|c|}{ Cultura Sucroolcooleira } \\
\hline Masculino & 7.330 & 89,54 & 7.421 & 91,17 & 7.799 & 91,57 \\
\hline Feminino & 856 & 10,46 & 719 & 8,83 & 718 & 8,43 \\
\hline \multirow[t]{2}{*}{ Totd } & 8.186 & 100,00 & 8.140 & 100,00 & $\mathbf{8 . 5 1 7}$ & 100,00 \\
\hline & \multicolumn{6}{|c|}{ Cultura das Frutas Cítricas } \\
\hline Masculino & 497 & 82,56 & 500 & 81,04 & 682 & 78,75 \\
\hline Ferninino & 105 & 17,44 & 117 & 18,96 & 184 & 21,25 \\
\hline Totsl & 602 & 100,00 & 617 & 100,00 & 866 & 100,00 \\
\hline
\end{tabular}

Nota: (*) Inclui todos os registros existentes na Base de Acidentes do Trabalho no Meio Rural $\left({ }^{* *}\right)$ Inclui um registro em 1997 , cujo o sexo era desconhecido.

Para a cultura sucroalcooleira, a variação ano a ano da participação feminina apresentou redução, enquanto em 1997, 10,5\% dos acidentes registrados tinham 
ocorrido com mulheres, em 1999, essa proporção caiu para 8,4\%, representando uma queda proporcional de 19\%. Em números absolutos, isso significou que 138 mulheres deixaram de se acidentar ou deixaram de ter seus acidentes registrados (Tabela 5).

Enquanto não ultrapassa os $11 \%$ tanto na cultura sucroalcooleira como no total dos acidentes do meio rural paulista a participação proporcional do sexo feminino, na cultura cítrica, ultrapassou ligeiramente os $20 \%$ dos registros.

Com participação mais significante no total dos acidentes registrados na cultura cítrica o sexo feminino revelou no período analisado um acréscimo de 79 casos de 1997 a 1999, passando de 105 para 184 eventos registrados. Proporcionalmente representava no início do período $17,4 \%$ do total dos registros passando para 21,2\% em 1999 (Tabela 5).

\subsubsection{Distribuição dos Registros de AT das culturas sucroalcooleiras e cítrica segundo tipo e sexo}

No cruzamento realizado entre tipo de acidente e sexo do acidentado, para as culturas sucroalcooleiras e cítrica, observa-se que nas culturas sucroalcooleiras a proporção de acidentes-tipo para o sexo é consideravelmente superior a encontrada na cultura cítrica nos anos analisados. Enquanto na cultura sucroalcooleira entre 1997 e 1999, o sexo masculino representou cerca de 90 a $92 \%$ dos ATs registrados, na cítrica esse percentual variou de cerca de 79 a $83 \%$ (Tabela 6).

Por tipo de acidente, nota-se na cultura sucroalcooleira, que os homens foram o sexo mais representativo tanto para os acidentes-tipo, como de trajeto e doenças do trabalho. Entretanto, nos acidentes-tipo, estes alcançaram nos três anos considerados 92\% dos registros de AT. O sexo feminino apresentou suas maiores participações nos acidentes de trajeto e nas doenças do trabalho (tabela 6). 
Para a cultura cítrica, também ocorre predomínio proporcional e numérico do sexo masculino nos tipos de acidentes analisados (acidente-tipo, de trajeto e doenças do trabalho) e maior participação proporcionalmente das mulheres nos acidentes de trajeto e nas doenças do trabalho. Entretanto, observa-se que as participações femininas, proporcionalmente são mais elevadas na cultura cítrica em relação a sucroalcooleira.

Tabela 6

Número e Proporção dos Registros de Acidentes do Trabalho nas Culturas Sucroalcooleiras e Citricas, por Sexo e Tipo de Acidente. Estado de São Paulo. 1997, 1998 e 1999

\begin{tabular}{|c|c|c|c|c|c|c|c|c|}
\hline \multirow{3}{*}{$\begin{array}{c}\text { Tipo } \\
\text { de } \\
\text { Acidente }\end{array}$} & \multicolumn{4}{|c|}{ Cultura Sucroalcooleira } & \multicolumn{4}{|c|}{ Cultura de Frutas Citricas } \\
\hline & \multicolumn{2}{|c|}{ Masculino } & \multicolumn{2}{|c|}{ Feminino } & \multicolumn{2}{|c|}{ Masculino } & \multicolumn{2}{|c|}{ Feminino } \\
\hline & No. & $\%$ & No. & $\%$ & No. & $\%$ & No. & $\%$ \\
\hline & \multicolumn{8}{|c|}{1997} \\
\hline Acidente-Tipo & 6.212 & 91,0 & 616 & 9,0 & 461 & 83,5 & 91 & 16,5 \\
\hline Acidente de Trajeto & 98 & 92,5 & 8 & 7,5 & 7 & 77,8 & 2 & 22,2 \\
\hline Doença de Trabalho & 991 & 81,4 & 226 & 18,6 & 29 & 74,4 & 10 & 25,6 \\
\hline \multirow[t]{2}{*}{ Totsl (*) } & 7.330 & 89,5 & 856 & 10,5 & 497 & 82,6 & 105 & $17 \mathrm{~A}$ \\
\hline & \multicolumn{8}{|c|}{1998} \\
\hline Acidente-Tipo & 6.677 & 91,9 & 592 & 8,1 & 472 & 81,9 & 104 & 18,1 \\
\hline Acidente de Trajeto & 107 & 86,3 & 17 & 13,7 & 12 & 63,2 & 7 & 36,8 \\
\hline Doença de Trabalho & 616 & 85,1 & 108 & 14,9 & 14 & 70,0 & 6 & 30,0 \\
\hline \multirow{2}{*}{ Total $\left({ }^{*}\right)$} & 7.421 & 91,2 & 719 & 8.8 & 500 & 81,0 & 117 & 19,0 \\
\hline & \multicolumn{8}{|c|}{1999} \\
\hline Acidente-Tïpo & 7.015 & 92,3 & 588 & 7,7 & 631 & $\overline{79,2}$ & 166 & 20,8 \\
\hline Acidente de Trajeto & 136 & 86,1 & 22 & 13,9 & 15 & 83,3 & 3 & 16,7 \\
\hline Doença de Trabalho & 625 & 85,6 & 105 & 14,4 & 35 & 72,9 & 13 & 27,1 \\
\hline Total $(*)$ & 7.799 & 916 & 718 & 8,4 & 682 & 78.8 & 184 & 21,2 \\
\hline
\end{tabular}

Nota: $\left(^{*}\right)$ Inclui registros de AT, cujo o tipo de acidente era ignorado

4.2.6 Distribuição dos registros de AT por faixa etária dos acidentados

Por grupos qüinqüenais de idade nota-se, para os registros de acidentes no meio rural paulista, nos três anos coletados que cerca de até $57 \%$ dos ATs registrados ocorrem entre a população menor de 30 anos de idade (Figura 3). São os jovens de 20 a 24, que apresentam a maior participação de acidentes registrados; estes sozinhos representam praticamente $1 / 4$ da população trabalhadora em área rural que registraram AT. Após os 60 anos, esta proporção não alcança os $2 \%$ de todos os registros de acidentes. 
Figura 3

Proporçõa de Registros de AT em Área Rural, segundo Ano da Ocorrência e Grupos de Idade Estado de São Paulo 1997, 1998 e 1999

\section{$\%$}

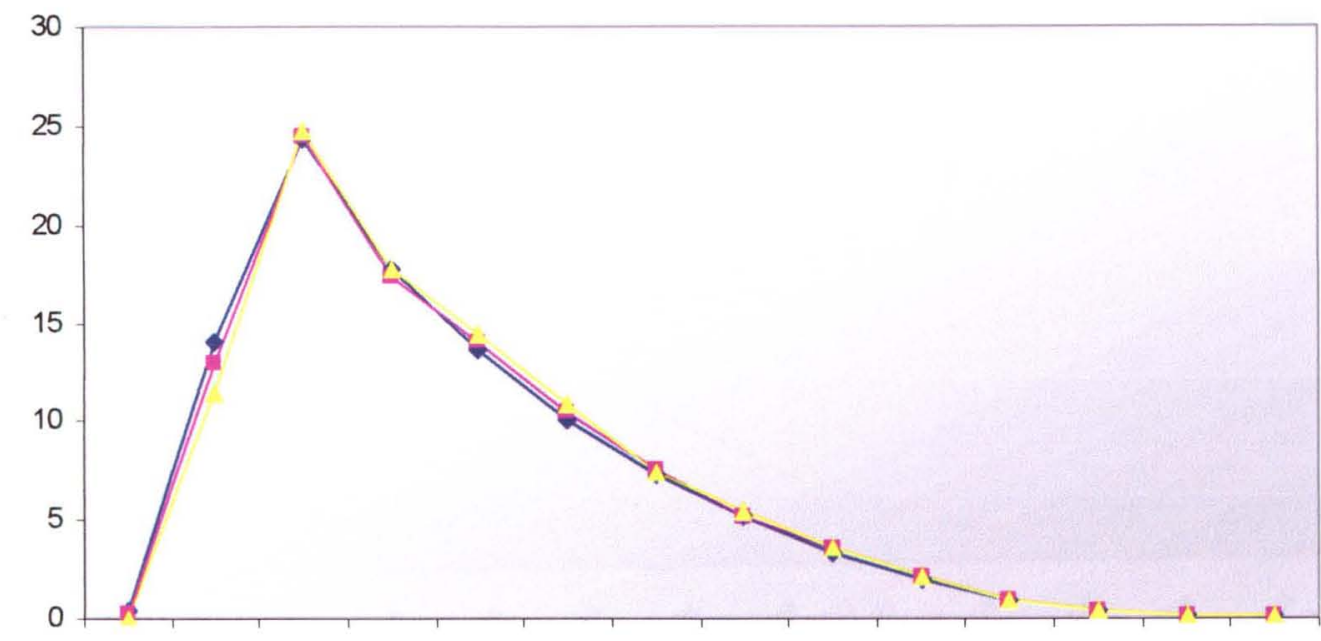

Gupos de Idade

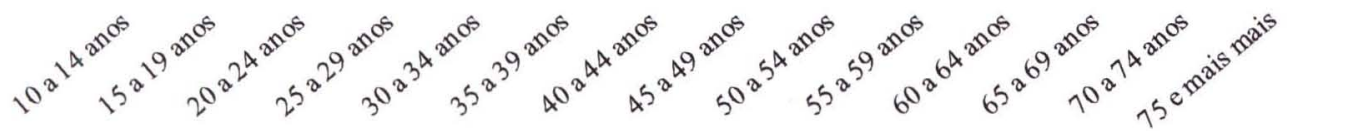
1999

Apresentando tendência semelhante a esta, a cultura sucroalcooleira pouco mostrou alterações no decorrer dos três anos analisados. Grande parte dos ATs foi registrada entre a população com menos de 40 anos de idade, entretanto essa proporção é um pouco maior às observadas no meio rural, neste caso, até $60 \%$ dos registros ocorreram com trabalhadores com idades inferiores a 30 anos. Entre estes, os jovens de 20 a 24 anos, mais uma vez, representavam a maior parcela de registros, esta faixa etária sozinha alcançava quase $29 \%$ de todos os acidentes registrados em 1999 (Figura 4). 
Figura 4

Proporção de Registros de AT em Cultura Sucroalcooleira, segundo Ano da Ocorrência e $\%$ Grupos de Idade Estado de São Paulo 1997, 1998 e 1999

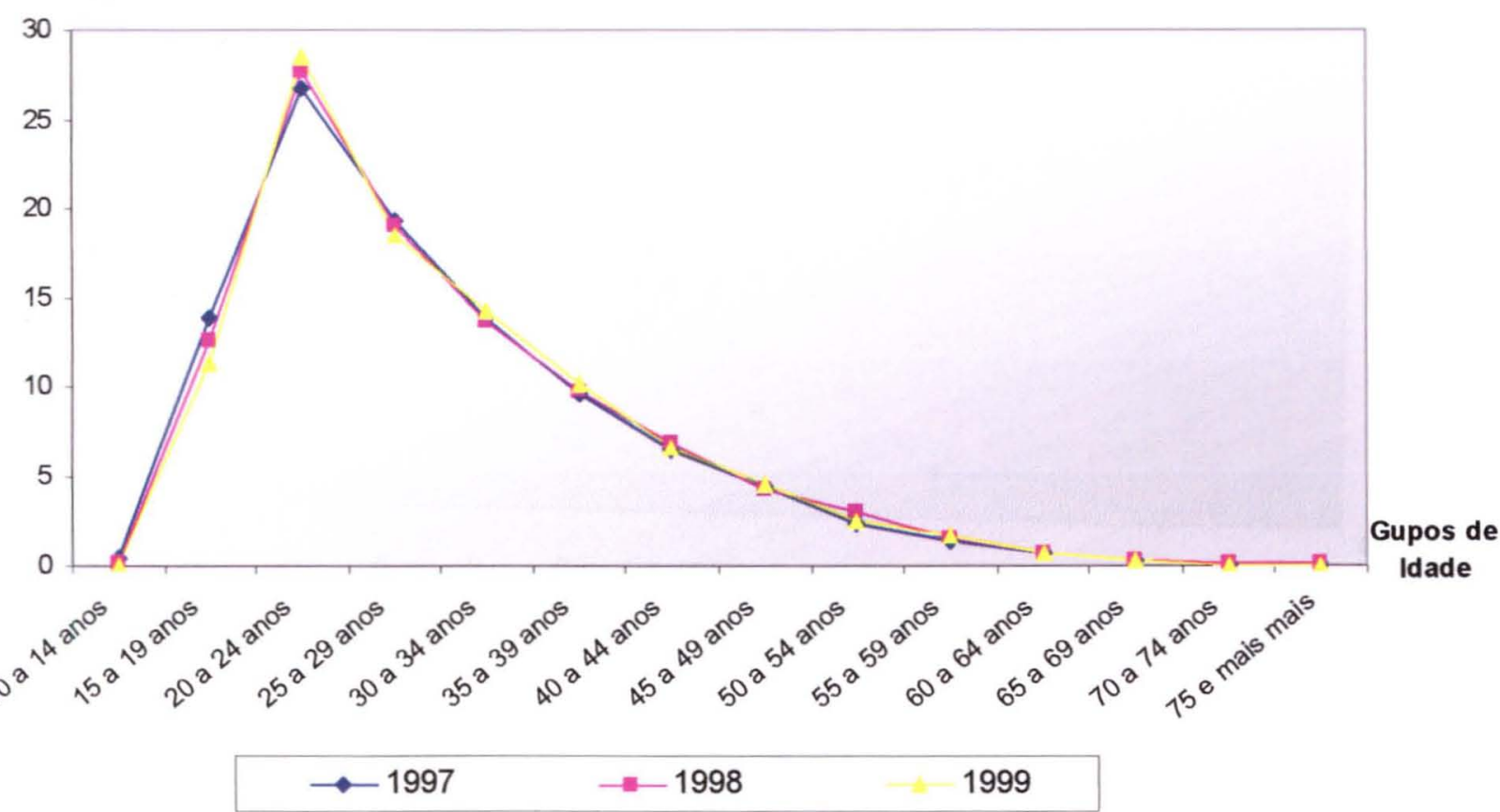

Com uma tendência distinta dos registros de acidentes do meio rural paulista e da cultura sucroalcooleira, a cultura cítrica não apresentou consonância em suas curvas de participação por faixa etária nos três anos analisados (Figura 5).

Apesar de registrar acidentes mais distribuídos entre as faixas etárias, comparado com a sucroalcooleira e os registros do meio rural, há uma concentração relevante de registros entre a população trabalhadora com menos de 40 anos, chegando a 62,3\% em 1997, em 1998 e 1999 essa proporção cai para cerca de 59,3\% e $58,8 \%$ respectivamente. Entre os menores de 30 anos, essa proporção não ultrapassa os $33 \%$ nos três anos analisados. Nota-se, que nas faixas mais velhas, a proporção de registros de acidentes entre os maiores de 60 anos, neste caso, chega alcançar 8,1\% dos acidentes registrados nessa cultura em 1998 (Figura 5). 


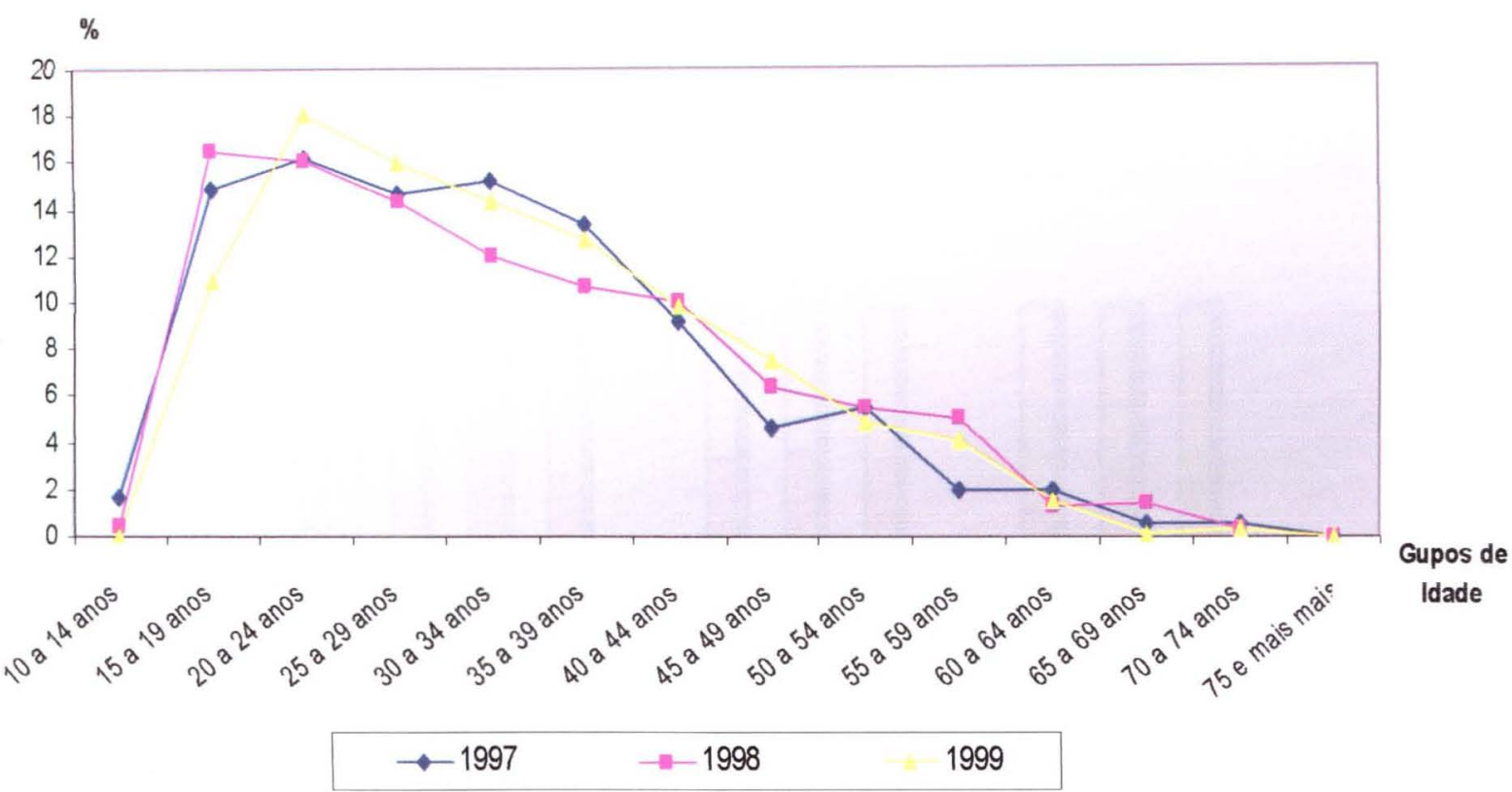

Com relação aos menores de 15 anos, esses se constituem de uma pequena parcela tanto para as culturas selecionadas como para o total de registros de acidentes do meio rural. Entretanto, a cultura das frutas cítricas é a que apresenta maior participação proporcional de jovens menores de 15 anos de idade em 1997 e 1998, apesar de não registrar nenhum acidente nessa faixa etária em 1999.

4.2.7 Distribuição dos registros de AT segundo menores de 18 anos

Os registros de AT em menores 18 anos constituem menos de 5\% entre os acidentes registrados no meio rural nos anos analisados. Enquanto em 1997, perfaziam 4,5\% do total dos registros, em 1998 eram 3,7\% e, em 1999, 2,9\%. Destes, $99 \%$ tinham entre 14 e 17 anos, proporção esta que se observa nos três anos analisados. Entre os jovens trabalhadores da cultura sucroalcooleira que registraram AT entre 1997 e 1999, nota-se que houve uma redução nesse período, tanto proporcional que passou de $3,6 \%$ para $1,83 \%$ respectivamente, quanto numérica, enquanto em 1997 eram registrados 293 AT com menores de 18 anos em 1999 
passou a 156. Com relação a sua distribuição interna, observa-se que a grande maioria destes registros, entre 98\% (1997) e 99\% (1998 e 1999) são de maiores de 14 anos (Figura 6).

Figura 6

Proporção de Registros de AT de Menores de 18 Anos em Áreas Rurais, por Ano do Acidente e Tipo de Cultura Estado de São Paulo 1997,1998 e 1999

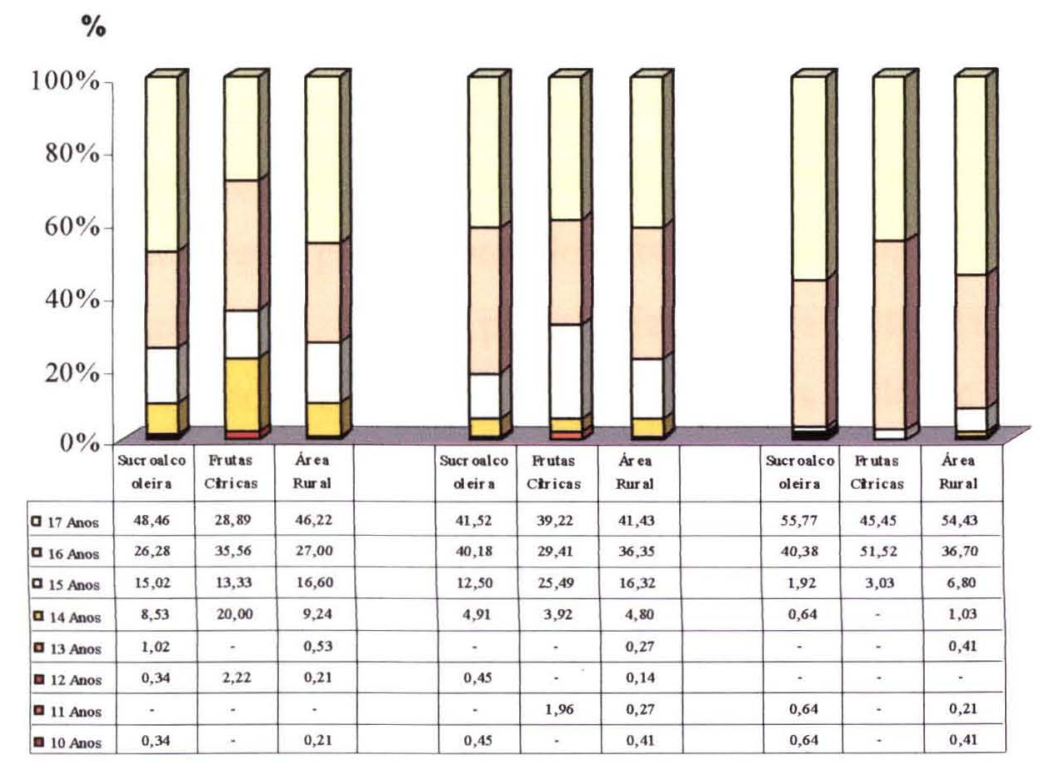

Observa-se dados preocupantes na PNAD, segundo a qual, 8,97\% das crianças e jovens adolescentes brasileiros entre 5 e 14 anos trabalham, sendo que $65 \%$ eles estão ocupados em atividades agrícolas e 35\% em atividades não agrícolas (DIEESE 2001).

Nesta pesquisa observou-se que a cultura sucoralcooleira apresenta 673 registros de AT com menores de 18 anos entre 1997 e 1999, o que representou 2,7\% do total de registros coletados neste período. Dos acidentes registrados com menores de 18 anos nessa cultura $1,34 \%$ tinha menos de 14 anos.

Com relação à cultura das frutas cítricas, apesar de numericamente inferiores aos da cultura sucroalcooleira, verifica-se uma maior proporção de registros de AT com menores de 18 anos em relação ao total de acidentes registrados por ano nesta 
cultura. Entretanto, observa-se que estes registros diminuem em 1999. Enquanto em 1997 perfaziam 7,5\% de todos os acidentes registrados neste ano, em 1999 não ultrapassavam 3,8\%. Chama a atenção sua distribuição interna, onde em 1999 não registrou nenhum AT com menores de 14 anos (Figura 6).

4.2.8 Distribuição da ocupação do trabalhador nas culturas sucroalcooleira e cítrica

Segundo a ocupação dos trabalhadores inseridos na cultura sucroalcooleira, nota-se um predomínio numérico e proporcional de trabalhadores identificados como rurais em todos os anos analisados, seguido pelos rurícolas e os cortadores de cana (Tabela 7), de modo geral, todas essas distintas classificações realizam a mesma atividade agrícola, que é o corte manual da cana-de-açúcar.

\section{Tabela 7}

Número e Proporção de Registros de Acidentes do Trabalho na Cultura Sucroalcooleira por Ocupação do Trabalhador. Estado de São Paulo. 1997, 1998 e 1999

\begin{tabular}{|c|c|c|c|c|c|c|}
\hline \multirow{3}{*}{$\begin{array}{c}\text { Categorias Profissionais } \\
\text { da Cultura } \\
\text { Sucroalcooleira }\end{array}$} & \multicolumn{6}{|c|}{ Ano do Acidente } \\
\hline & \multicolumn{2}{|c|}{1997} & \multicolumn{2}{|c|}{1998} & \multicolumn{2}{|c|}{1999} \\
\hline & No. & $\%$ & No. & $\%$ & No. & $\%$ \\
\hline Ajudante de Serviços Agrícolas/de Lavoura & 582 & 7,11 & 600 & 7,37 & 749 & 8,79 \\
\hline Aplicador de Defensivo Agricola & 1 & 0,01 & - & - & 1 & 0,01 \\
\hline Bituqueiro & 3 & 0,04 & 4 & 0,05 & 3 & 0,04 \\
\hline Canavicultor & 70 & 0,86 & 119 & 1,46 & 187 & 2,20 \\
\hline Catador de Cana & 3 & 0,04 & 3 & 0,04 & 9 & 0,11 \\
\hline Cortador de Cana & 565 & 6,90 & 389 & 4,78 & 602 & 7,07 \\
\hline Lavrador & 289 & 3,53 & 566 & 6,95 & 752 & 8,83 \\
\hline Lider de Queimada & - & - & - & - & 2 & 0,02 \\
\hline Motorista & 127 & 1,55 & 116 & 1,43 & 120 & 1,41 \\
\hline Não Especificado & 2 & 0,02 & 2 & 0,02 & 17 & 0,20 \\
\hline Operador de Máquima Agrícola & 56 & 0,68 & 51 & 0,63 & 124 & 1,46 \\
\hline Rurícola & 1.950 & 23,82 & 1.788 & 21,97 & 1.580 & 18,55 \\
\hline Trabalhador Rural & 4.374 & 53,43 & 4.328 & 53,17 & 4.206 & 49,38 \\
\hline Tratorista & 164 & 2,00 & 174 & 2,14 & 165 & 1,94 \\
\hline Total & 8.186 & 100,00 & 8.140 & 100,00 & 8.517 & 100,00 \\
\hline
\end{tabular}

(-) Fenômeno inexistente 
As menores proporções são encontradas entre os aplicadores de defensivos agrícolas líder de queimada e bituqueiros. Os motoristas, operadores de máquinas agrícolas e tratoristas, atividades que exigem algum conhecimento mais específico, apresentaram uma proporção inferior a $2,14 \%$ dos registros de AT (Tabela 7).

Com relação à cultura cítrica, as maiores proporções também foram encontradas entre aqueles responsáveis pela colheita das frutas. A grande maioria está classificada como trabalhador rural, em menor escala encontra-se os colhedores e os rurícolas. Os motoristas, operadores de máquinas agrícolas e tratoristas, atividades que exigem algum conhecimento, apresentaram proporções inferiores a 6,5\% (Tabela 8). Observa-se uma queda entre 1997 e 1999 dos registrados como trabalhadores rurais e um aumento dos colhedores.

Tabela 8

Número e Proporção de Registros de Acidentes do Trabalho na Cultura de Frutas Cítricas por Ocupação do Trabalhador. Estado de São Paulo. 1997, 1998 e 1999

\begin{tabular}{|c|c|c|c|c|c|c|}
\hline \multirow{3}{*}{$\begin{array}{c}\text { Categorias Profis sionais } \\
\text { da Cultura de } \\
\text { Frutas Citricas }\end{array}$} & \multicolumn{6}{|c|}{ Ano do Acidente } \\
\hline & \multicolumn{2}{|c|}{1997} & \multicolumn{2}{|c|}{1998} & \multicolumn{2}{|c|}{1999} \\
\hline & No. & $\%$ & No. & $\%$ & No. & $\%$ \\
\hline Ajudante de Serviços Agrícolas/de Lavoura & 55 & 9,14 & 17 & 2,76 & 43 & 4,97 \\
\hline Carregador de Laranjas & - & - & - & - & 6 & 0,69 \\
\hline Colhedor & 23 & 3,82 & 28 & 4,54 & 163 & 18,82 \\
\hline Colhedor de Laranja & 5 & 0,83 & 7 & 1,13 & 45 & 5,20 \\
\hline Colhedor de Citus & 5 & 0,83 & 4 & 0,65 & 3 & 0,35 \\
\hline Lavrador & 9 & 1,50 & 13 & 2,11 & 9 & 1,04 \\
\hline Motorista & 4 & 0,66 & 6 & 0,97 & 3 & 0,35 \\
\hline Não Especificado & - & - & 1 & 0,16 & - & - \\
\hline Operador de Máquina Agrícola & 7 & 1,16 & 14 & 2,27 & 27 & 3,12 \\
\hline Ruricola & 33 & 5,48 & 38 & 6,16 & 26 & 3,00 \\
\hline Trabalhador Rural & 422 & 70,10 & 454 & 73,58 & 493 & 56,93 \\
\hline Tratorista & 39 & 6,48 & 35 & 5,67 & 48 & 5,54 \\
\hline Total & 602 & 100,00 & 617 & 100,00 & 866 & 100,00 \\
\hline
\end{tabular}

(-) Fenômeno inexistente

Em suma, nota-se que os ATs atingem mais os trabalhadores de atividades manuais. Comparando a cultura da cana à de frutas cítricas, observa-se uma maior participação proporcional dos tratoristas da cultura cítrica aos da cana (Tabelas 7 e 8). 
4.2.9 Distribuição dos registros de AT segundo as partes do corpo atingidas

Por ano de acidente, nota-se entre 1997 e 1999, que poucas alterações ocorreram com relação às partes do corpo atingidas no acidente, seja entre os registros de acidentes do meio rural como das duas culturas em questão.

Em 1997, as principais partes do corpo atingidas no acidente tipo do meio rural foram os membros inferiores (pés e pernas) e os membros superiores (dedos e mãos), verificadas também no sexo masculino. No sexo feminino, a cabeça, particularmente os olhos têm importante destaque, sobressaindo-se inclusive aqueles acidentes envolvendo os membros inferiores (pernas) e os membros superiores (dedos e mãos) (Tabela 9).

Neste ano, as partes do corpo mais atingidas nos acidentes de trajeto foram os membros inferiores (pernas) e o tronco para os registros da área rural. Para as mulheres, os membros superiores.

Entre as doenças do trabalho, o tronco foi a mais atingida, inclusive entre os homens, sendo seguida pelos membros superiores (braços e mãos). A mesma tendência foi observada para o sexo feminino.

Em 1998 os acidentes-tipo ocorridos no meio rural, continuam sendo os dos membros inferiores, mas dessa vez são as pernas que apresentam destaque, seguidos pelos membros superiores (dedos), situação esta verificada também para o sexo masculino. No sexo feminino, a principal parte do corpo atingida também são os membros inferiores, mas neste caso os pés.

Entre os acidentes de trajeto, o tronco foi a parte mais atingida entre os homens, enquanto para as mulheres foram os membros inferiores (pernas) (Tabela 10). 
Tabela 9

Distribuição do Número e Proporção dos Registros de Acidentes do Trabalho em Área Rural por Sexo, segundo Típo e principais Partes do Corpo atingidas no Acidente

Estado de São Paulo

1997

\begin{tabular}{|c|c|c|c|c|c|c|}
\hline \multirow{3}{*}{$\begin{array}{c}\text { Principais Partes } \\
\text { do Corpo Atigidas no } \\
\text { AT }\end{array}$} & \multicolumn{6}{|c|}{ Acidente-Tipo } \\
\hline & \multicolumn{2}{|c|}{ Total } & \multicolumn{2}{|c|}{ Masculino } & \multicolumn{2}{|c|}{ Feminino } \\
\hline & No. & $\%$ & No. & $\%$ & No. & $\%$ \\
\hline Membros Inferiores/Pés & 3.783 & 20,50 & 3.642 & 20,53 & 141 & 19,94 \\
\hline Membros Inferiores/Pemas & 3.437 & 18,63 & 3.328 & 18,76 & 109 & 15,42 \\
\hline Membros Superiores/Dedos & 3.073 & 16,66 & 2.982 & 16,81 & 91 & 12,87 \\
\hline Membros Superiores/Mãos & 2.693 & 14,60 & 2.599 & 14,65 & 94 & 13,30 \\
\hline Cabeça/Olhos & 2.540 & 13,77 & 2.419 & 13,63 & 121 & 17,11 \\
\hline Membros Superiores/Braços & 1.051 & 5,70 & 978 & 5,51 & 73 & 10,33 \\
\hline Tronco & 858 & 4,65 & 816 & 4,60 & 42 & 5,94 \\
\hline Cabeça & 386 & 2,09 & 376 & 2,12 & 10 & 1,41 \\
\hline Demais partes do corpo & 629 & 3,41 & 603 & 3,40 & 26 & 3,68 \\
\hline \multirow[t]{2}{*}{ Total } & 18.450 & 100,00 & 17.743 & 96,17 & 707 & 3,83 \\
\hline & \multicolumn{6}{|c|}{ Acidente de Trajeto } \\
\hline Membros Inferiores/Pernas & 54 & 16,93 & 52 & 16,83 & 2 & 20,00 \\
\hline Tronco & 47 & 14,73 & 45 & 14,56 & 2 & 20,00 \\
\hline Ignorado & 33 & 10,34 & 33 & 10,68 & - & - \\
\hline Cabeça & 31 & 9,72 & 31 & 10,03 & - & - \\
\hline Membros Inferiores/Pés & 29 & 9,09 & 27 & 8,74 & 2 & 20,00 \\
\hline Membros Superiores/Braços & 23 & 7,21 & 23 & 7,44 & - & - \\
\hline Membros Superiores/Mãos & 22 & 6,90 & 19 & 6,15 & 3 & 30,00 \\
\hline Membros Superiores/Dedos & 16 & 5,02 & 16 & 5,18 & - & - \\
\hline Cabeça/Othos & 9 & 2,82 & 8 & 2,59 & 1 & 10,00 \\
\hline Tronco-Membros Inferiores/Pemas & 7 & 2,19 & 7 & 2,27 & - & - \\
\hline Cabeça-Tronco & 5 & 1,57 & 5 & 1,62 & - & - \\
\hline Membros Superiores/Braços-Membros Inferiores/Pemas & 5 & 1,57 & 5 & 1,62 & - & - \\
\hline Cabeça-Membros Inferiores/Pernas & 4 & 1,25 & 4 & 1,29 & - & - \\
\hline Demais partes do corpo & 34 & 10,66 & 34 & 11,00 & - & - \\
\hline \multirow[t]{2}{*}{ Total } & 319 & 100,00 & $309^{\prime}$ & 96,87 & 10 & 3,13 \\
\hline & \multicolumn{6}{|c|}{ Doença do Trabalho } \\
\hline Tronco & 853 & 37,40 & 796 & 38,92 & 57 & 24,15 \\
\hline Membros Superiores/Braços & 657 & 28,80 & 572 & 27,97 & 85 & 36,02 \\
\hline Membros Superiores/Mãos & 500 & 21,92 & 426 & 20,83 & 74 & 31,36 \\
\hline Membros Inferiores/Pemas & 66 & 2,89 & 61 & 2,98 & 5 & 2,12 \\
\hline Membros Superiores/Dedos & 51 & 2,24 & 46 & 2,25 & 5 & 2,12 \\
\hline Ignorado & 41 & 1,80 & 41 & 2,00 & - & - \\
\hline Membros Inferiores/Pés & 27 & 1,18 & 25 & 1,22 & 2 & 0,85 \\
\hline Demais partes do corpo & 86 & 3,77 & 78 & 3,81 & 8 & 3,39 \\
\hline Total & 2.281 & 100,00 & 2.045 & 89,65 & 236 & 10,35 \\
\hline Total Geral (*) & 21.166 & 100,00 & 20.205 & 95,46 & 961 & 4,54 \\
\hline
\end{tabular}

Nota: $\left(^{*}\right)$ Inchi os acidentes cujo a parte do corpo era ignorada (-) Fenômeno inexistente 
Tabela 10

Distribuição do Número e Proporção dos Registros de Acidentes do Trabalho em Área Rural por Sexo, segundo Tipo e principais Partes do Corpo atingidas no Acidente

Estado de São Paulo

1998

\begin{tabular}{|c|c|c|c|c|c|c|}
\hline \multirow{3}{*}{$\begin{array}{c}\text { Principais Partes } \\
\text { do Corpo Atigidas no } \\
\text { AT }\end{array}$} & \multicolumn{6}{|c|}{ Acidente-Tipo } \\
\hline & \multicolumn{2}{|c|}{ Total } & \multicolumn{2}{|c|}{ Masculino } & \multicolumn{2}{|c|}{ Feminino } \\
\hline & No. & $\%$ & No. & $\%$ & No. & $\%$ \\
\hline Membros Inferiores/Pemas & 3.439 & 19,23 & 3.138 & 19,42 & 301 & 17,45 \\
\hline Membros Superiores/Dedos & 3.416 & 19,11 & 3.115 & 19,28 & 301 & 17,45 \\
\hline Membros Inferiores/Pés & 3.325 & 18,60 & 2.971 & 18,39 & 354 & 20,52 \\
\hline Membros Superiores/Mãos & 2.759 & 15,43 & 2.516 & 15,57 & 243 & 14,09 \\
\hline Cabeça/Othos & 2.252 & 12,60 & 2.050 & 12,69 & 202 & 11,71 \\
\hline Membros Superiores/Braços & 919 & 5,14 & 773 & 4,78 & 146 & 8,46 \\
\hline Tronco & 830 & 4,64 & 721 & 4,46 & 109 & 6,32 \\
\hline Demais partes do corpo & 940 & 5,26 & 871 & 5,39 & 69 & 4,00 \\
\hline \multirow[t]{2}{*}{ Total } & $17.880^{\circ}$ & 100,00 & $\mathbf{1 6 . 1 5 5}$ & 90,35 & 1.725 & 9,65 \\
\hline & \multicolumn{6}{|c|}{ Acidente de Trajeto } \\
\hline Tronco & 61 & 19,37 & 51 & 20,48 & 10 & 15,15 \\
\hline Membros Inferiores/Pemas & 49 & 15,56 & 37 & 14,86 & 12 & 18,18 \\
\hline Membros Superiores/Braços & 37 & 11,75 & 28 & 11,24 & 9 & 13,64 \\
\hline Cabeça & 29 & 9,21 & 22 & 8,84 & 7 & 10,61 \\
\hline Membros Superiores/Mãos & 29 & 9,21 & 23 & 9,24 & 6 & 9,09 \\
\hline Membros Inferiores/Pés & 23 & 7,30 & 18 & 7,23 & 5 & 7,58 \\
\hline Membros Superiores/Dedos & 12 & 3,81 & 11 & 4,42 & 1 & 1,52 \\
\hline Tronco-Membros Inferiones/Pemas & 7 & 2,22 & 5 & 2,01 & 2 & 3,03 \\
\hline Ignorado & 7 & 2,22 & 7 & 2,81 & - & - \\
\hline Politraumatismo & 7 & 2,22 & 7 & 2,81 & - & - \\
\hline Membros Superiores/Braços-Tronco & 5 & 1,59 & 4 & 1,61 & 1 & 1,52 \\
\hline Cabeça-Tronco & 4 & 1,27 & 4 & 1,61 & - & - \\
\hline Membros Superiores/Braços-Membros Inferiores/Pemas & 4 & 1,27 & 3 & 1,20 & 1 & 1,52 \\
\hline Membros Superiores/Mãos-Membros Inferiores/Pernas & 4 & 1,27 & 2 & 0,80 & 2 & 3,03 \\
\hline Membros Superiores-Membros Inferiores & 4 & 1,27 & 1 & 0,40 & 3 & 4,55 \\
\hline Demais partes do corpo & 33 & 10,48 & 26 & 10,44 & 7 & 10,61 \\
\hline \multirow[t]{2}{*}{ Total } & $315^{\prime}$ & 100,00 & 249 & 79,05 & 66 & 20,95 \\
\hline & \multicolumn{6}{|c|}{$\begin{array}{l}\text { Doenca do Trabalho } \\
\end{array}$} \\
\hline Tronco & 632 & 40,25 & 553 & 35,22 & 79 & 5,03 \\
\hline Membros Superiores/Braços & 412 & 26,24 & 308 & 19,62 & 104 & 6,62 \\
\hline Membros Superiores/Mãos & 373 & 23,76 & 305 & 19,43 & 68 & 4,33 \\
\hline Membros Inferiores/Pernas & 47 & 2,99 & 40 & 2,55 & 7 & 0,45 \\
\hline Demais partes do corpo & 106 & 6,75 & 87 & 5,54 & 19 & 1,21 \\
\hline Total & 1.570 & 100,00 & 1.293 & 82,36 & 277 & 17,64 \\
\hline Total Geral ( $\left.{ }^{(}\right)$ & 19.851 & 100,00 & 17.774 & 89,54 & 2.077 & 10,46 \\
\hline
\end{tabular}

Nota: (*) Inchi os acidentes cujo a parte do corpo era ignorada

(-) Fenômeno inexistente 
Tabela 11

Distribuição do número e proporção dos Registros de Acidentes do Trabalho em Área Rural por Sexo, segundo Tipo e principais Partes do Corpo atingidas no Acidente

Estado de São Paulo

1999

\begin{tabular}{|c|c|c|c|c|c|c|}
\hline \multirow{3}{*}{$\begin{array}{c}\text { Principais Partes } \\
\text { do Corpo Atigidas no } \\
\text { AT }\end{array}$} & \multicolumn{6}{|c|}{ Acidente-Tipo } \\
\hline & \multicolumn{2}{|c|}{ Total } & \multicolumn{2}{|c|}{ Masculino } & \multicolumn{2}{|c|}{ Feminino } \\
\hline & No. & $\%$ & No. & $\%$ & No. & $\%$ \\
\hline Membros Inferiores/Pemas & 2.867 & 19,05 & 2.645 & 19,38 & 222 & 15,79 \\
\hline Membros Superiores/Dedos & 2.798 & 18,59 & 2.551 & 18,69 & 247 & 17,57 \\
\hline Membros Inferiores/Pés & 2.758 & 18,32 & 2.482 & 18,19 & 276 & 19,63 \\
\hline Membros Superiores/Mãos & 2.168 & 14,40 & 1.992 & 14,60 & 176 & 12,52 \\
\hline Cabeça/Ohos & 1.988 & 13,21 & 1.792 & 13,13 & 196 & 13,94 \\
\hline Membros Superiores/Braços & 840 & 5,58 & 715 & 5,24 & 125 & 8,89 \\
\hline Tronco & 747 & 4,96 & 654 & 4,79 & 93 & 6,61 \\
\hline Demais partes do corpo & 886 & 5,89 & 815 & 5,97 & 71 & 5,05 \\
\hline \multirow[t]{2}{*}{ Total } & 15.052 & 100,00 & 13.646 & 90,66 & 1.406 & 9,34 \\
\hline & \multicolumn{6}{|c|}{ Acidente de Trajeto } \\
\hline Membros Inferiores/Pemas & 51 & 17,59 & 40 & 16,26 & 11 & 25,00 \\
\hline Tronco & 45 & 15,52 & 38 & 15,45 & 7 & 15,91 \\
\hline Cabeça & 43 & 14,83 & 37 & 15,04 & 6 & 13,64 \\
\hline Membros Inferiores/Pés & 24 & 8,28 & 20 & 8,13 & 4 & 9,09 \\
\hline Membros Superiores/Braços & 24 & 8,28 & 19 & 7,72 & 5 & 11,36 \\
\hline Membros Superiores/Dedos & 18 & 6,21 & 18 & 7,32 & - & - \\
\hline Membros Superiores/Măos & 16 & 5,52 & 13 & 5,28 & 3 & 6,82 \\
\hline Doenca Ocupacional & 9 & 3,10 & 6 & 2,44 & 3 & 6,82 \\
\hline Ignorado & 8 & 2,76 & 7 & 2,85 & 1 & 2,27 \\
\hline Cabeça-Tronco & 6 & 2,07 & 5 & 2,03 & 1 & 2,27 \\
\hline Membros Superiores/Braços-Membros Inferiores/Pemas & 6 & 2,07 & 5 & 2,03 & 1 & 2,27 \\
\hline Cabeça-Membros Inferiores/Pernas & 5 & 1,72 & 5 & 2,03 & - & - \\
\hline Cabeça/Othos & 5 & 1,72 & 5 & 2,03 & - & - \\
\hline Demais partes do corpo & 30 & 10,34 & 28 & 11,38 & 2 & 4,55 \\
\hline \multirow[t]{2}{*}{ Total } & $290^{\prime}$ & 100,00 & 246 & 84,83 & 44 & 15,17 \\
\hline & \multicolumn{6}{|c|}{ Doença do Trabalho } \\
\hline Tronco & 536 & 37,33 & 462 & 40,14 & 74 & 25,96 \\
\hline Membros Superiores/Braços & 378 & 26,32 & 274 & 23,81 & 104 & 36,49 \\
\hline Membros Superiores/Mãos & 318 & 22,14 & 257 & 22,33 & 61 & 21,40 \\
\hline Membros Inferiores/Pemas & 46 & 3,20 & 38 & 3,30 & 8 & 2,81 \\
\hline Membros Superiores/Dedos & 32 & 2,23 & 28 & 2,43 & 4 & 1,40 \\
\hline Membros Superiores & 24 & 1,67 & 13 & 1,13 & 11 & 3,86 \\
\hline Ignorado & 19 & 1,32 & 15 & 1,30 & 4 & 1,40 \\
\hline Membros Inferiores/Pés & 16 & 1,11 & 14 & 1,22 & 2 & 0,70 \\
\hline Demais partes do corpo & 67 & 4,67 & 50 & 4,34 & 17 & 5,96 \\
\hline Total & 1.436 & 100,00 & 1.151 & 80,15 & 285 & 19,85 \\
\hline Total Geral (*) & 16.850 & 100,00 & 15.106 & 89,65 & 1.744 & 10,35 \\
\hline
\end{tabular}

Nota: (*) Inclui os acidentes cujo a parte do corpo era ignorada

$(-)$ Fenômeno inexistente 
Para as doenças do trabalho, foram respectivamente o tronco e os membros superiores, nestes o destaque foram os braços, sobretudo para o sexo feminino (Tabela 10).

Em 1999, os registros de acidentes do meio rural para os acidentes-tipo ocorridos entre os homens foram os membros inferiores (pernas), seguidos pelos membros superiores (dedos). Para as mulheres, a parte do corpo mais atingida também foram os membros inferiores, entretanto, neste caso, o destaque foram os pés (Tabela 11).

Com relação aos acidentes de trajeto, ambos os sexos apresentam as mesmas partes do corpo atingidas, a saber: os membros superiores (pernas), o tronco e a cabeça (Tabela 11).

Para a cultura sucroalcooleira, os membros inferiores (pés e pernas) foram as partes mais atingidas tanto entre os homens como nas mulheres, chama atenção, entre o sexo feminino, a cabeça/olhos, como a segunda parte do corpo mais atingida (Tabela 12).

Enquanto para as mulheres a parte mais atingida nos acidentes de trajeto são os membros superiores (mãos), para o sexo masculino foram os membros inferiores (pernas) (Tabela 12).

Para as doenças do trabalho, o tronco foi a mais atingida nos homens, e os membros superiores (braços) nas mulheres (Tabela 12).

Para o ano de 1998, nesta mesma cultura, observa-se que os membros inferiores foram as partes mais atingidas, sendo as pernas para o sexo masculino, e os pés para o sexo feminino (Tabela 13). 
Tabela 12

Distribuição do Número e Proporção dos Registros de Acidentes do Trabalho da Cultura Sucroalcooleira por segundo Tipo e principais Partes do Corpo atingidas no Acidente

Estado de São Paulo

1997

\begin{tabular}{|c|c|c|c|c|c|c|}
\hline \multirow{3}{*}{$\begin{array}{c}\text { Principais Partes } \\
\text { do Corpo Atigidas no } \\
\text { AT }\end{array}$} & \multicolumn{6}{|c|}{ Acidente-Tipo } \\
\hline & \multicolumn{2}{|c|}{ Total } & \multicolumn{2}{|c|}{ Masculino } & \multicolumn{2}{|c|}{ Feminino } \\
\hline & No. & $\%$ & No. & $\%$ & No. & $\%$ \\
\hline Membros Inferiores/Pés & 1.299 & 19,02 & 1.175 & 18,92 & 124 & 20,13 \\
\hline Membros Inferiores/Pernas & 1.298 & 19,01 & 1.196 & 19,25 & 102 & 16,56 \\
\hline Membros Superiores/Dedos & 1.136 & 16,64 & 1.052 & 16,93 & 84 & 13,64 \\
\hline Cabeça/Olhos & 1.113 & 16,30 & 1.003 & 16,15 & 110 & 17,86 \\
\hline Membros Superiores/Mãos & 1.033 & 15,13 & 951 & 15,31 & 82 & 13,31 \\
\hline Membros Superiores/Braços & 369 & 5,40 & 304 & 4,89 & 65 & 10,55 \\
\hline Tronco & 289 & 4,23 & 259 & 4,17 & 30 & 4,87 \\
\hline Demais partes do corpo & 291 & 4,26 & 272 & 4,38 & 19 & 3,08 \\
\hline \multirow[t]{2}{*}{ Total } & 6.828 & 100,00 & $6.212^{\prime}$ & 90,98 & 616 & 9,02 \\
\hline & \multicolumn{6}{|c|}{ Acidente de Trajeto } \\
\hline Membros Inferiores/Pernas & 21 & 19,81 & 19 & 19,39 & 2 & 25,00 \\
\hline Tronco & 15 & 14,15 & 13 & 13,27 & 2 & 25,00 \\
\hline Membros Inferiores/Pés & 11 & 10,38 & 10 & 10,20 & 1 & 12,50 \\
\hline Membros Superiores/Mãos & 10 & 9,43 & 7 & 7,14 & 3 & 37,50 \\
\hline Membros Superiores/Braços & 9 & 8,49 & 9 & 9,18 & - & - \\
\hline Cabeça & 7 & 6,60 & 7 & 7,14 & - & - \\
\hline Membros Superiores/Dedos & 6 & 5,66 & 6 & 6,12 & - & - \\
\hline Ignorado & 5 & 4,72 & 5 & 5,10 & - & - \\
\hline Tronco-Membros Inferiores/Pernas & 5 & 4,72 & 5 & 5,10 & - & - \\
\hline Tronco-Membros Inferiores/Pés & 3 & 2,83 & 3 & 3,06 & - & - \\
\hline Cabeça-Membros Inferiores/Pemas & 2 & 1,89 & 2 & 2,04 & - & - \\
\hline Cabeça/Olhos & 2 & 1,89 & 2 & 2,04 & - & - \\
\hline Demais partes do corpo & 10 & 9,43 & 10 & 10,20 & - & - \\
\hline \multirow[t]{2}{*}{ Total } & 106 & 100,00 & 98 & 92,45 & 8 & 7,55 \\
\hline & \multicolumn{6}{|c|}{ Doença do Trabalho } \\
\hline Tronco & 454 & 37,30 & 399 & 40,26 & 55 & 24,34 \\
\hline Membros Superiores/Braços & 368 & 30,24 & 287 & 28,96 & 81 & 35,84 \\
\hline Membros Superiores/Mãos & 278 & 22,84 & 207 & 20,89 & 71 & 31,42 \\
\hline Membros Superiores/Dedos & 31 & 2,55 & 26 & 2,62 & 5 & 2,21 \\
\hline Membros Inferiores/Pernas & 27 & 2,22 & 23 & 2,32 & 4 & 1,77 \\
\hline Demais partes do corpo & 59 & 4,85 & 49 & 4,94 & 10 & 4,42 \\
\hline Total & 1.217 & 100,00 & 991 & 81,43 & 226 & 18,57 \\
\hline Total Geral (*) & 8.186 & 100,00 & 7.330 & 89,54 & 856 & 10,46 \\
\hline
\end{tabular}

Nota: (*) Inclui os acidentes cujo a parte do corpo era ignorada

(-) Fenômeno inexistente 
Tabela 13

Distribuição do Número e proporção dos Registros de Acidentes do Trabalho da Cultura Sucroalcooleira por Sexo, segundo Tipo e principais Partes do Corpo atingidas no Acidente

Estado de São Paulo

1998

\begin{tabular}{|c|c|c|c|c|c|c|}
\hline \multirow{3}{*}{$\begin{array}{c}\text { Principais Partes } \\
\text { do Corpo Atigidas no } \\
\text { AT }\end{array}$} & \multicolumn{6}{|c|}{ Acidente-Tipo } \\
\hline & \multicolumn{2}{|c|}{ Total } & \multicolumn{2}{|c|}{ Masculino } & \multicolumn{2}{|c|}{ Ferminino } \\
\hline & No. & $\%$ & No. & $\%$ & No. & $\%$ \\
\hline Membros Inferiores/Pernas & 1.451 & 19,96 & 1.340 & 20,07 & 111 & 18,75 \\
\hline Membros Superiores/Dedos & 1.416 & 19,48 & 1.310 & 19,62 & 106 & 17,91 \\
\hline Membros Inferiores/Pés & 1.386 & 19,07 & 1.271 & 19,04 & 115 & 19,43 \\
\hline Membros Superiores/Mãos & 1.162 & 15,99 & 1.072 & 16,06 & 90 & 15,20 \\
\hline Cabeça/Olhos & 1.066 & 14,67 & 982 & 14,71 & 84 & 14,19 \\
\hline Membros Superiores/Braços & 264 & 3,63 & 220 & 3,29 & 44 & 7,43 \\
\hline Tronco & 240 & 3,30 & 211 & 3,16 & 29 & 4,90 \\
\hline Cabeça & 117 & 1,61 & 111 & 1,66 & 6 & 1,01 \\
\hline Demais partes do corpo & 167 & 2,30 & 160 & 2,40 & 7 & 1,18 \\
\hline \multirow[t]{2}{*}{ Total } & 7.269 & 100,00 & $6.677^{\prime}$ & 91,86 & 592 & $\mathbf{8 , 1 4}$ \\
\hline & \multicolumn{6}{|c|}{ Acidente de Trajeto } \\
\hline Tronco & 28 & 22,58 & 26 & 24,30 & 2 & 11,76 \\
\hline Membros Superiores/Braços & 16 & 12,90 & 15 & 14,02 & 1 & 5,88 \\
\hline Cabeça & 15 & 12,10 & 13 & 12,15 & 2 & 11,76 \\
\hline Membros Inferiores/Pernas & 15 & 12,10 & 13 & 12,15 & 2 & 11,76 \\
\hline Membros Superiores/Mãos & 14 & 11,29 & 11 & 10,28 & 3 & 17,65 \\
\hline Membros Inferiores/Pés & 6 & 4,84 & 5 & 4,67 & 1 & 5,88 \\
\hline Membros Superiores/Dedos & 4 & 3,23 & 4 & 3,74 & - & - \\
\hline Ignorado & 3 & 2,42 & 3 & 2,80 & - & - \\
\hline Membros Superiores/Braços-Tronco & 3 & 2,42 & 2 & 1,87 & 1 & 5,88 \\
\hline Péscoco & 3 & 2,42 & 2 & 1,87 & 1 & 5,88 \\
\hline Membros Superiores/Mãos-Membros Inferiores/Pemas & 2 & 1,61 & 1 & 0,93 & 1 & 5,88 \\
\hline Demais partes do corpo & 15 & 12,10 & 12 & 11,21 & 3 & 17,65 \\
\hline \multirow[t]{2}{*}{ Total } & 124 & 100,00 & 107 & 86,29 & 17 & $\mathbf{1 3 , 7 1}$ \\
\hline & \multicolumn{6}{|c|}{ Doença do Trabalho } \\
\hline Tronco & 292 & 40,33 & 261 & 42,37 & 31 & 28,70 \\
\hline Membros Superiores/Mãos & 197 & 27,21 & 166 & 26,95 & 31 & 28,70 \\
\hline Membros Superiores/Braços & 176 & 24,31 & 140 & 22,73 & 36 & 33,33 \\
\hline Membros Inferiores/Pemas & 22 & 3,04 & 19 & 3,08 & 3 & 2,78 \\
\hline Membros Superiores/Dedos & 10 & 1,38 & 9 & 1,46 & 1 & 0,93 \\
\hline Demais partes do corpo & 27 & 3,73 & 21 & 3,41 & 6 & 5,56 \\
\hline Total & 724 & 100,00 & 616 & 85,08 & 108 & 14,92 \\
\hline Total Geral (*) & 8.140 & 100,00 & $\mathbf{7 . 4 2 1}$ & 91,17 & 719 & $\mathbf{8 , 8 3}$ \\
\hline
\end{tabular}

Nota: $\left(^{*}\right)$ Inclui os acidentes cujo a parte do corpo era ignorada

(-) Fenômeno inexistente 
Tabela 14

Distribuição do Número e Proporção dos Registros de Acidentes do Trabalho da Cultura Sucroalcooleira por Sex segundo Tipo e principais Partes do Corpo atingidas no Acidente Estado de São Paulo

1999

\begin{tabular}{|c|c|c|c|c|c|c|}
\hline \multirow{3}{*}{$\begin{array}{c}\text { Principais Partes } \\
\text { do Corpo Atigidas no } \\
\text { AT }\end{array}$} & \multicolumn{6}{|c|}{ Acidente-Tipo } \\
\hline & \multicolumn{2}{|c|}{ Total } & \multicolumn{2}{|c|}{ Masculino } & \multicolumn{2}{|c|}{ Feminino } \\
\hline & No. & $\%$ & No. & $\%$ & No. & $\%$ \\
\hline Membros Inferiores/Pernas & 1.557 & 20,48 & 1.461 & 20,83 & 96 & 16,33 \\
\hline Membros Superiores/Dedos & 1.497 & 19,69 & 1.382 & 19,70 & 115 & 19,56 \\
\hline Membros Inferiores/Pés & 1.410 & 18,55 & 1.289 & 18,37 & 121 & 20,58 \\
\hline Cabeça/Olhos & 1.246 & 16,39 & 1.144 & 16,31 & 102 & 17,35 \\
\hline Membros Superiores/Mãos & 1.070 & 14,07 & 996 & 14,20 & 74 & 12,59 \\
\hline Membros Superiores/Braços & 291 & 3,83 & 254 & 3,62 & 37 & 6,29 \\
\hline Tronco & 218 & 2,87 & 192 & 2,74 & 26 & 4,42 \\
\hline Cabeça & 117 & 1,54 & 112 & 1,60 & 5 & 0,85 \\
\hline Demais partes do corpo & 197 & 2,59 & 185 & 2,64 & 12 & 2,04 \\
\hline \multirow[t]{2}{*}{ Total } & 7.603 & 100,00 & 7.015 & 92,27 & 588 & 7,73 \\
\hline & \multicolumn{6}{|c|}{ Acidente de Trajeto } \\
\hline Membros Inferiores/Pernas & 31 & 19,62 & 25 & 18,38 & 6 & 27,27 \\
\hline Cabeça & 27 & 17,09 & 26 & 19,12 & 1 & 4,55 \\
\hline Tronco & 27 & 17,09 & 22 & 16,18 & 5 & 22,73 \\
\hline Membros Superiores/Braços & 11 & 6,96 & 9 & 6,62 & 2 & 9,09 \\
\hline Membros Superiores/Dedos & 9 & 5,70 & 9 & 6,62 & - & - \\
\hline Doenca Ocupacional & 8 & 5,06 & 5 & 3,68 & 3 & 13,64 \\
\hline Membros Inferiores/Pés & 8 & 5,06 & 7 & 5,15 & 1 & 4,55 \\
\hline Membros Superiores/Mãos & 8 & 5,06 & 6 & 4,41 & 2 & 9,09 \\
\hline Cabeça-Membros Inferiores/Pemas & 4 & 2,53 & 4 & 2,94 & & - \\
\hline Cabeça-Tronco & 4 & 2,53 & 3 & 2,21 & 1 & 4,55 \\
\hline Demais partes do corpo & 21 & 13,29 & 20 & 14,71 & 1 & 4,55 \\
\hline \multirow[t]{2}{*}{ Total } & 158 & 100,00 & 136 & 86,08 & 22 & 13,92 \\
\hline & \multicolumn{6}{|c|}{ Doença do Trabalho } \\
\hline Tronco & 268 & 36,71 & 237 & 37,92 & 31 & 29,52 \\
\hline Membros Superiores/Braços & 193 & 26,44 & 156 & 24,96 & 37 & 35,24 \\
\hline Membros Superiores/Mãos & 186 & 25,48 & 158 & 25,28 & 28 & 26,67 \\
\hline Membros Infeniores/Pernas & 22 & 3,01 & 18 & 2,88 & 4 & 3,81 \\
\hline Membros Superiores/Dedos & 18 & 2,47 & 17 & 2,72 & 1 & 0,95 \\
\hline Demais partes do corpo & 43 & 5,89 & 39 & 6,24 & 4 & 3,81 \\
\hline Total & 730 & 100,00 & 625 & 85,62 & 105 & 14,38 \\
\hline Total Geral (*) & $\mathbf{8 . 5 1 7}$ & 100,00 & 7.799 & 91,57 & 718 & $\mathbf{8 , 4 3}$ \\
\hline
\end{tabular}

Nota: $\left(^{*}\right)$ Inclui os acidentes cujo a parte do corpo era ignorada

(-) Fenômeno inexistente

No que diz respeito aos acidentes de trajeto, neste ano, a principal parte do corpo atingida foi o tronco, para o sexo masculino esta parte do corpo atingiu quase $1 / 4$ dos trabalhadores (Tabela 13). 
Com uma proporção ligeiramente superior a $40 \%$, o tronco foi a parte do corpo atingida no sexo masculino no que se refere às doenças do trabalho, enquanto para as mulheres os membros superiores (braços) (tabela13).

Em 1999, último ano de análise, a cultura sucroalcooleira, apresentou para os acidentes-tipo, os membros inferiores (pernas) e os membros superiores (dedos), as principais partes do corpo atingidas pelo sexo masculino, para o sexo feminino foram os pés dos membros inferiores (Tabela 14).

Entre os acidentes de trajeto nesse ano, tanto para os homens como para as mulheres a principal parte do corpo atingida foram as pernas. Chama atenção também, a proporção de acidentes que atingiram o tronco feminino (Tabela 14).

Quanto às doenças do trabalho, as partes mais atingidas para o sexo masculino envolvidos na cultura sucroalcooleira foram o tronco e os braços (membros superiores), enquanto para as mulheres ocorreu o inverso (Tabela 14).

Para os trabalhadores da cultura de frutas cítricas em 1997, os membros inferiores (pés) foram as partes do corpo mais atingidas para ambos os sexos entre os acidentes-tipo (Tabela 15).

Entre os acidentes de trajeto, em 1997, foi alta a proporção de ocorrências cuja parte do corpo mais atingida era ignorada entre o sexo masculino, para o sexo feminino, no entanto, somente a cabeça (olhos) e os membros inferiores (pés) apresentaram registro (Tabela 15).

Para as doenças do trabalho, os homens apresentaram uma alta proporção envolvendo o tronco ( $72 \%$ ) como a parte do corpo mais atingida, enquanto para o sexo feminino foram os membros superiores, braços e mãos, respectivamente (Tabela 15). 
Tabela 15

Distribuição do Número e Proporção dos Registros de Acidentes do Trabalho da Cultura das Frutas Cítrica segundo Tipo e principais Partes do Corpo atingidas no Acidente

Estado de São Paulo

1997

\begin{tabular}{|c|c|c|c|c|c|c|}
\hline \multirow{3}{*}{$\begin{array}{c}\text { Principais Partes } \\
\text { do Corpo Atigidas no } \\
\text { AT }\end{array}$} & \multicolumn{6}{|c|}{ Acidente-Tipo } \\
\hline & \multicolumn{2}{|c|}{ Total } & \multicolumn{2}{|c|}{ Masculino } & \multicolumn{2}{|c|}{ Feminino } \\
\hline & No. & $\%$ & No. & $\%$ & No. & $\%$ \\
\hline Membros Inferiores/Pés & 96 & 17,39 & 79 & 17,14 & 17 & 18,68 \\
\hline Membros Inferiores/Pernas & 78 & 14,13 & 71 & 15,40 & 7 & 7,69 \\
\hline Membros Superiores/Dedos & 75 & 13,59 & 68 & 14,75 & 7 & 7,69 \\
\hline Membros Superiores/Mãos & 74 & 13,41 & 62 & 13,45 & 12 & 13,19 \\
\hline Cabeça/Olhos & 56 & 10,14 & 45 & 9,76 & 11 & 12,09 \\
\hline Tronco & 54 & 9,78 & 42 & 9,11 & 12 & 13,19 \\
\hline Membros Superiones/Braços & 48 & 8,70 & 40 & 8,68 & 8 & 8,79 \\
\hline Cabeça & 21 & 3,80 & 17 & 3,69 & 4 & 4,40 \\
\hline Ignorado & 11 & 1,99 & 10 & 2,17 & 1 & 1,10 \\
\hline Demais partes do corpo & 39 & 7,07 & 27 & 5,86 & 12 & 13,19 \\
\hline \multirow[t]{2}{*}{ Total } & $\mathbf{5 5 2}$ & 100,00 & $461^{\circ}$ & 83,51 & 91 & 16,49 \\
\hline & \multicolumn{6}{|c|}{ Acidente de Trajeto } \\
\hline Ignorado & 2 & 22,22 & 2 & 28,57 & - & - \\
\hline Cabeça-Membros Superiores/Mãos & 1 & 11,11 & 1 & 14,29 & - & - \\
\hline Cabeça/Olhos & 1 & 11,11 & - & - & 1 & 50,00 \\
\hline Membros Inferiores/Pernas & 1 & 11,11 & 1 & 14,29 & - & - \\
\hline Membros Inferiores/Pés & 1 & 11,11 & - & - & 1 & 50,00 \\
\hline Membros Superiores/Braços & 1 & 11,11 & 1 & 14,29 & - & - \\
\hline Membros Superiores/Dedos & 1 & 11,11 & 1 & 14,29 & - & - \\
\hline Tronco & 1 & 11,11 & 1 & 14,29 & - & - \\
\hline \multirow[t]{2}{*}{ Total } & 9 & 100,00 & $7^{\circ}$ & $\mathbf{7 7 , 7 8}$ & 2 & 22,22 \\
\hline & \multicolumn{6}{|c|}{ Doenca do Trabalho } \\
\hline Tronco & 23 & 58,97 & 21 & 72,41 & 2 & 20,00 \\
\hline Membros Superiores/Braços & 5 & 12,82 & 1 & 3,45 & 4 & 40,00 \\
\hline Membros Superiores/Mãos & 5 & 12,82 & 2 & 6,90 & 3 & 30,00 \\
\hline Membros Inferiores/Pernas & 2 & 5,13 & 1 & 3,45 & 1 & 10,00 \\
\hline Membros Superiores/Dedos & 2 & 5,13 & 2 & 6,90 & - & - \\
\hline Ignorado & 1 & 2,56 & 1 & 3,45 & - & - \\
\hline Tronco-Membros Inferiores/Pemas & 1 & 2,56 & 1 & 3,45 & - & - \\
\hline Total & 39 & 100,00 & $29^{\circ}$ & 74,36 & 10 & 25,64 \\
\hline Total Geral (*) & 602 & 100,00 & 497 & 82,56 & 105 & 17,44 \\
\hline
\end{tabular}

Nota: $\left(^{*}\right)$ Inclui os acidentes cujo a parte do corpo era ignorada

(-) Fenômeno inexistente 
Tabela 16

Distribuição do número e Proporção dos Registros de Acidentes do Trabalho da Cultura das Frutas Cítricas por Sexo, segundo Tipo e principais Partes do Corpo atingidas no Acidente

Estado de São Paulo

1998

\begin{tabular}{|c|c|c|c|c|c|c|}
\hline \multirow{3}{*}{$\begin{array}{l}\text { Principais Partes } \\
\text { do Corpo Atigidas no }\end{array}$} & \multicolumn{6}{|c|}{ Acidente-Tipo } \\
\hline & \multicolumn{2}{|c|}{ Total } & \multicolumn{2}{|c|}{ Masculino } & \multicolumn{2}{|c|}{ Feminino } \\
\hline & No. & $\%$ & No. & $\%$ & No. & $\%$ \\
\hline Membros Inferiores/Pés & 108 & 18,75 & 89 & 18,86 & 19 & 18,27 \\
\hline Membros Inferiores/Pemas & 90 & 15,63 & 74 & 15,68 & 16 & 15,38 \\
\hline Membros Superiores/Mãos & 73 & 12,67 & 67 & 14,19 & 6 & 5,77 \\
\hline Tronco & 67 & 11,63 & 52 & 11,02 & 15 & 14,42 \\
\hline Membros Superiores/Dedos & 64 & 11,11 & 53 & 11,23 & 11 & 10,58 \\
\hline Membros Superiores/Braços & 61 & 10,59 & 44 & 9,32 & 17 & 16,35 \\
\hline Cabeça/Olhos & 47 & 8,16 & 37 & 7,84 & 10 & 9,62 \\
\hline Cabeça & 23 & 3,99 & 21 & 4,45 & 2 & 1,92 \\
\hline Demais partes do corpo & 43 & 7,47 & 35 & 7,42 & 8 & 7,69 \\
\hline \multirow[t]{2}{*}{ Total } & 576 & 100,00 & $472^{\circ}$ & 81,94 & 104 & 18,06 \\
\hline & \multicolumn{6}{|c|}{ Acidente de Trajeto } \\
\hline Cabeça & 4 & 21,05 & 3 & 25,00 & 1 & 14,29 \\
\hline Tronco & 4 & 21,05 & 3 & 25,00 & 1 & 14,29 \\
\hline Membros Inferiores/Pemas & 3 & 15,79 & 2 & 16,67 & 1 & 14,29 \\
\hline Membros Inferiores/Pemas & 3 & 15,79 & 1 & 8,33 & 2 & 28,57 \\
\hline Cabeça-Membros Superiores/Braços-Tronco & 1 & 5,26 & - & - & 1 & 14,29 \\
\hline Membros Superiores/Braços & 1 & 5,26 & - & - & 1 & 14,29 \\
\hline Membros Superiores/Dedos & 1 & 5,26 & 1 & 8,33 & - & - \\
\hline Membros Superiores/Mãos & 1 & 5,26 & 1 & 8,33 & - & - \\
\hline Membros Superiores/Mãos-Tronco & 1 & 5,26 & 1 & 8,33 & - & - \\
\hline \multirow[t]{2}{*}{ Totel } & 19 & 100,00 & $12^{\prime}$ & 63,16 & 7 & 36,84 \\
\hline & \multicolumn{6}{|c|}{ Doenca do Trabolho } \\
\hline Tronco & 10 & 50,00 & 8 & 57,14 & 2 & 33,33 \\
\hline Membros Superiores/Mãos & 5 & 25,00 & 2 & 14,29 & 3 & 50,00 \\
\hline Ignorado & 1 & 5,00 & 1 & 7,14 & - & - \\
\hline Membros Inferiores/Pemas & 1 & 5,00 & 1 & 7,14 & - & - \\
\hline Membros Inferiores/Pemas & 1 & 5,00 & 1 & 7,14 & - & - \\
\hline Membros Superiores/Braços & 1 & 5,00 & - & - & 1 & 16,67 \\
\hline Membros Superiores/Dedos & 1 & 5,00 & 1 & 7,14 & - & - \\
\hline Total & 20 & 100,00 & $14^{\prime}$ & 70,00 & 6 & 30,00 \\
\hline Total Ceral (*) & 617 & 100,00 & 500 & 81,04 & 117 & 18,96 \\
\hline
\end{tabular}

Nota: $\left(^{*}\right)$ Inchi os acidentes cujo a parte do corpo era ignorada

(-) Fenômeno inexistente 
Tabela 17

Distribuição do Número e Proporção dos Registros de Acidentes do Trabalho da Cultura das Frutas Cítricas por؟ segundo Tipo e principais Partes do Corpo atingidas no Acidente Estado de São Paulo

1999

\begin{tabular}{|c|c|c|c|c|c|c|}
\hline \multirow{3}{*}{$\begin{array}{c}\text { Principais Partes } \\
\text { do Corpo Atigidas no } \\
\text { AT } \\
\end{array}$} & \multicolumn{6}{|c|}{ Acidente-Tipo } \\
\hline & \multicolumn{2}{|c|}{ Total } & \multicolumn{2}{|c|}{ Masculino } & \multicolumn{2}{|c|}{ Feminino } \\
\hline & No. & $\%$ & No. & $\%$ & No. & $\%$ \\
\hline Membros Inferiores/Pés & 144 & 18,07 & 108 & 17,12 & 36 & 21,69 \\
\hline Membros Superiores/Dedos & 108 & 13,55 & 87 & 13,79 & 21 & 12,65 \\
\hline Membros Superiores/Mãos & 108 & 13,55 & 93 & 14,74 & 15 & 9,04 \\
\hline Cabeça/Othos & 104 & 13,05 & 83 & 13,15 & 21 & 12,65 \\
\hline Membros Inferiores/Pemas & 92 & 11,54 & 78 & 12,36 & 14 & 8,43 \\
\hline Tronco & 84 & 10,54 & 62 & 9,83 & 22 & 13,25 \\
\hline Membros Superiores/Braços & 73 & 9,16 & 56 & 8,87 & 17 & 10,24 \\
\hline Cabeça & 37 & 4,64 & 30 & 4,75 & 7 & 4,22 \\
\hline Demais partes do corpo & 47 & 5,90 & 34 & 5,39 & 13 & 7,83 \\
\hline \multirow[t]{2}{*}{ Total } & 797 & 100,00 & $631^{\circ}$ & 79,17 & 166 & 20,83 \\
\hline & \multicolumn{6}{|c|}{ Acidente de Trajeto } \\
\hline Cabesa & 3 & 16,67 & 2 & 13,33 & 1 & 33,33 \\
\hline Cabeça/Olhos & 3 & 16,67 & 3 & 20,00 & & - \\
\hline Membros Superiores/Braços & 3 & 16,67 & 2 & 13,33 & 1 & 33,33 \\
\hline Ignorado & 2 & 11,11 & 1 & 6,67 & 1 & 33,33 \\
\hline Membros Inferiores/Pés & 2 & 11,11 & 2 & 13,33 & - & - \\
\hline Tronco & 2 & 11,11 & 2 & 13,33 & - & - \\
\hline Membros Inferiores/Pemas & 1 & 5,56 & 1 & 6,67 & - & - \\
\hline Demais partes do corpo & 2 & 11,11 & 2 & 13,33 & - & - \\
\hline \multirow[t]{2}{*}{ Total } & 18 & 100,00 & $15^{\circ}$ & 83,33 & 3 & 16,67 \\
\hline & \multicolumn{6}{|c|}{ Doença do Trabalho } \\
\hline Tronco & 32 & 66,67 & 24 & 68,57 & 8 & 61,54 \\
\hline Membros Superiores/Braços & 4 & 8,33 & 4 & 11,43 & & - \\
\hline Membros Superiores/Mãos & 3 & 6,25 & 1 & 2,86 & 2 & 15,38 \\
\hline Membros Inferiores/Pemas & 2 & 4,17 & 2 & 5,71 & & $\cdot$ \\
\hline Membros Inferiores/Pés & 2 & 4,17 & 2 & 5,71 & & - \\
\hline Cabeca & 1 & 2,08 & & - & 1 & 7,69 \\
\hline Cabega-Tronco & 1 & 2,08 & 1 & 2,86 & & - \\
\hline Demais partes do corpo & 3 & 6,25 & 1 & 2,86 & 2 & 15,38 \\
\hline Total & 48 & 100,00 & $35^{\circ}$ & 72,92 & 13 & 27,08 \\
\hline Total Geral (*) & 866 & 100,00 & 682 & $\mathbf{7 8 , 7 5}$ & 184 & 21,25 \\
\hline
\end{tabular}

Nota: (*) Inchi os acidentes cujo a parte do corpo era ignorada

$(-)$ Fenômeno inexistente

No ano de 1998, os membros inferiores, ou seja, os pés, foram a principal parte do corpo atingida no acidente-tipo para a cultura cítrica em ambos os sexos (Tabela 16). 
Observa-se que a cabeça foi a principal parte do corpo atingida nos acidentes de trajeto para o sexo masculino, que junto com o tronco perfizeram $50 \%$ dos acidentes registrados. $O$ sexo feminino, entretanto, mostrou que as pernas foram mais sensíveis aos acidentes de trajeto (Tabela 16).

Também, em 1998, as doenças do trabalho atingiram mais o tronco em mais de $50 \%$ dos acidentes registrados para o sexo masculino, enquanto para o sexo feminino foram as mãos (membros superiores) (Tabela 16).

Na cultura cítrica, em 1999, para os acidentes tipos, os pés foram as partes do corpo mais atingidas nos acidentes envolvendo o sexo masculino e feminino (Tabela 17).

Para os acidentes de trajeto foram os olhos para o sexo masculino e para o sexo feminino foram, com as mesmas proporções, a cabeça e os braços (Tabela 17).

Foi alta a proporção de trabalhadores da cultura cítrica em 1999, que teve o tronco como a principal parte do corpo atingida nas doenças do trabalho (Tabela 17).

Em suma, as partes do corpo atingidas nos acidentes e doenças do trabalho, observadas nos registros de AT são muitas e diversificadas.

Com relação aos acidentes-tipo nota-se um predomínio dos membros inferiores e posteriormente dos membros superiores tanto para os acidentes registrados no meio rural, como para aqueles das culturas sucroalcooleiras e cítricas, que se repete praticamente em todos os anos levantados.

Entre os membros inferiores, as partes mais atingidas são os pés e as pernas e nos membros superiores são os dedos e as mãos. 
Quanto aos acidentes de trajeto, ocorre uma maior diversidade entre os anos analisados, mas sobressaem-se os membros inferiores, sendo que neste caso as pernas apresentam maior relevância.

Para as doenças do trabalho, o tronco é a principal parte do corpo atingida, sendo seguida pelos membros superiores e inferiores, respectivamente.

\subsection{Estimativa dos coeficientes de incidência acumulada, mortalidade e letalidade}

\subsection{1 Área rural}

Tomando como base o número de trabalhadores residentes de 10 a 69 anos ocupados em atividades rurais e contribuintes de Instituto de Previdência Oficial, obtidos pelo BME do IBGE, e os registros de AT registrados na Previdência Social, foi possível criar áreas elaboradas, segundo os critérios expostos no capítulo de Material e Método. Sua distribuição territorial no Estado de São Paulo correspondeu à elaboração de 33 áreas (Anexo 4), que englobaram todos os municípios do Estado de São Paulo, com exceção de Águas de São Pedro e São Caetano do Sul que não apresentaram população residente ocupada em atividade rural, nem registro de AT.

A taxa de incidência acumulada do Estado de São Paulo para 1997 dos registros de AT ocorridos em área rural foi de praticamente 56 acidentes por mil trabalhadores residentes no Estado, sendo 58,2 para o sexo masculino e 42,8 para o sexo feminino (Tabela 18).

Neste ano, dentre as áreas elaboradas, observam-se quatro com taxas de incidência superiores a 100 acidentes registrados por mil trabalhadores no meio rural. Estas se situam geograficamente no centro-oeste e no norte do Estado de São Paulo, e são: a área 12 (156,7 registros de AT por mil trabalhadores), a área 13 (120,8 
registros de AT por mil trabalhadores), a área 18 (122,8 registros de AT por mil trabalhadores) e a área 21 (176,1 registros de AT por mil trabalhadores) (Figura $7 \mathrm{e}$ Tabela 18).

As áreas com as mais baixas taxas de incidência estão localizadas mais próximas ao litoral e da RMSP, no extremo leste do Estado de São Paulo e no Vale do Ribeira (Figura 7 e Tabela 18), que vão de 2,10 (área 3) até 16,7 registros de AT por mil trabalhadores (área 4).

Por sexo, em geral, nota-se que os homens apresentam as mais altas taxas, muitas inclusive superiores as da população total, exceções são observadas nas áreas $3,9,11,21,23,28,30$ e 32 , onde, em 1997, as taxas femininas são mais elevadas (Tabela 18).

Em 1998, observa-se queda na taxa de incidência acumulada para o total do Estado de São Paulo em relação ao ano anterior (Tabela 18). A taxa de incidência acumulada superior a 56 registros por mil trabalhadores em 1997 passou em 1998 para menos de 50 (49,1 registros de AT por mil trabalhadores), o que significou uma redução de $12,3 \%$. Com praticamente a mesma proporção de queda de $12,0 \%$, o sexo masculino, expressou ainda uma taxa de incidência acumulada superior a 50 registros de AT por mil trabalhadores. Quanto às mulheres, houve uma redução maior $(15,3 \%)$ nas taxas entre 1997 e 1998, passando de 42,75 para 36,21 registros de AT por mil trabalhadores, respectivamente (Tabela 18 ).

Neste ano, as menores taxas de incidência acumulada para 0 total da população foram observadas nas áreas 1, 2, 3, 4 e 5, como nas áreas 9 e 31 (Figura 8 e Tabela 18).

No que diz respeito à evolução temporal das áreas elaboradas, exceções feitas às áreas: $2,7,9,14,15,1619,21,28,30$ e 33, as demais registram diminuição em 
suas taxas de incidência acumulada para o total da população entre 1997 e 1998, sendo a que registrou o maior aumento foi a 19 (Tabela 18).

Tabela 18

Taxa de Incidência Acumulada dos Registros de AT de Áreas Rurais do Estado de São Paulo 1997, 1998 e 1999

\begin{tabular}{|c|c|c|c|c|c|c|c|c|c|}
\hline \multirow{3}{*}{$\begin{array}{c}\text { Áreas } \\
\text { Elaboradas }\end{array}$} & \multicolumn{9}{|c|}{ Taxa de Incidência Acumulada (por mil trabalhadores) } \\
\hline & \multicolumn{3}{|c|}{1997} & \multicolumn{3}{|c|}{1998} & \multicolumn{3}{|c|}{1999} \\
\hline & Total & Masculino & Feminino & Total & Masculino & Feminino & Total & Masculino & Feminino \\
\hline Estado de São Paulo & 55,98 & 58,19 & 42,75 & 49,07 & 51,23 & 36,21 & 43,15 & 45,12 & 31,46 \\
\hline Área 1 & 15,68 & 16,19 & 5,94 & 14,60 & 14,86 & 9,67 & 11,26 & 11,56 & 5,66 \\
\hline Área 2 & 8,34 & 8,38 & 8,19 & 8,62 & 8,77 & 7,98 & 2,93 & 2,89 & 3,11 \\
\hline Área 3 & 2,10 & 2,08 & 2,26 & 2,24 & 2,14 & 3,28 & 2,94 & 2,92 & 3,17 \\
\hline Área 4 & 16,75 & 17,31 & 11,59 & 13,75 & 14,85 & 3,80 & 17,49 & 18,50 & 8,38 \\
\hline Área 5 & 22,22 & 23,21 & 16,81 & 15,61 & 16,37 & 11,47 & 11,72 & 12,57 & 7,03 \\
\hline Área 6 & 30,15 & 31,57 & 22,30 & 29,42 & 31,59 & 17,38 & 22,38 & 24,04 & 13,20 \\
\hline Área 7 & 70,97 & 78,78 & 35,37 & 78,19 & 88,21 & 32,58 & 42,70 & 45,97 & 27,88 \\
\hline Área 8 & 42,67 & 47,45 & 23,14 & 34,79 & 39,30 & 16,48 & 22,10 & 23,86 & 15,02 \\
\hline Área 9 & 15,78 & 15,70 & 16,17 & 17,05 & 17,75 & 13,39 & 13,05 & 13,16 & 12,46 \\
\hline Área 10 & 88,10 & 89,68 & 78,79 & 58,35 & 60,77 & 44,23 & 40,20 & 42,16 & 28,84 \\
\hline Área 11 & 34,42 & 33,66 & 38,39 & 29,42 & 30,30 & 24,83 & 23,90 & 23,78 & 24,49 \\
\hline Área 12 & 156,75 & 167,46 & 109,45 & 121,63 & 129,90 & 85,20 & 96,73 & 100,49 & 80,23 \\
\hline Área 13 & 120,76 & 130,04 & 74,45 & 75,48 & 81,74 & 44,21 & 35,05 & 35,17 & 34,47 \\
\hline Área 14 & 66,73 & 73,42 & 45,43 & 71,52 & 80,24 & 43,87 & 91,30 & 98,92 & 67,18 \\
\hline Área 15 & 49,03 & 52,74 & 31,37 & 60,33 & 66,79 & 29,74 & 47,44 & 51,41 & 28,67 \\
\hline Área 16 & 50,62 & 55,25 & 21,18 & 58,20 & 63,47 & 24,78 & 34,40 & 37,45 & 15,10 \\
\hline Área 17 & 79,99 & 87,48 & 36,52 & 47,53 & 49,81 & 34,34 & 22,25 & 24,09 & 11,61 \\
\hline Área 18 & 122,79 & 131,14 & 74,09 & 97,05 & 106,21 & 43,62 & 156,29 & 175,71 & 43,18 \\
\hline Área 19 & 30,31 & 31,75 & 21,67 & 46,73 & 50,29 & 25,33 & 36,93 & 39,48 & 21,65 \\
\hline Área 20 & 41,89 & 44,13 & 23,37 & 39,61 & 42,15 & 18,54 & 30,17 & 31,51 & 19,09 \\
\hline Área 21 & 66,54 & 64,78 & 78,76 & 69,27 & 68,77 & 72,75 & 64,32 & 67,75 & 40,46 \\
\hline Área 22 & 176,12 & 183,71 & 114,75 & 125,40 & 129,57 & 91,71 & 106,83 & 115,09 & 40,06 \\
\hline Área 23 & 50,66 & 49,46 & 56,28 & 39,28 & 38,43 & 43,70 & 42,05 & 41,10 & 46,99 \\
\hline Área 24 & 89,94 & 96,89 & 59,47 & 86,51 & 90,96 & 67,02 & 88,63 & 89,86 & 83,25 \\
\hline Área 25 & 51,63 & 54,04 & 39,84 & 47,49 & 49,67 & 36,79 & 44,57 & 48,95 & 23,07 \\
\hline Área 26 & 41,33 & 42,59 & 33,51 & 28,04 & 29,26 & 20,54 & 14,55 & 15,60 & 8,06 \\
\hline Área 27 & 34,93 & 37,74 & 34,79 & 27,96 & 29,05 & 14,51 & 32,30 & 33,24 & 20,81 \\
\hline Área 28 & 35,10 & 33,44 & 55,78 & 36,15 & 33,56 & 68,43 & 48,45 & 43,99 & 104,11 \\
\hline Área 29 & 34,07 & 34,64 & 29,32 & 19,93 & 19,26 & 25,52 & 59,74 & 61,90 & 41,84 \\
\hline Área 30 & 36,17 & 35,84 & 38,92 & 40,46 & 40,32 & 41,65 & 32,98 & 33,59 & 27,74 \\
\hline Área 31 & 26,29 & 27,59 & 17,61 & 19,42 & 19,52 & 18,76 & 21,99 & 23,90 & 9,28 \\
\hline Área 32 & 67,96 & 67,85 & 68,97 & 70,85 & 71,25 & 67,29 & 43,68 & 45,11 & 31,04 \\
\hline Área 33 & 55,69 & 58,83 & 43,28 & 67,34 & 72,21 & 48,11 & 45,02 & 48,31 & 32,04 \\
\hline
\end{tabular}

Nota: Inclui todos os registros existentes na Base de Acidentes do Trabalho no Meio Rural.

(-) Fenômeno inexistente 
Figura 7

Taxa de Incidência Acumulada dos Registros de AT em Áreas Rurais

Municípios do Estado de São Paulo Agrupados em Áreas Elaboradas

1997

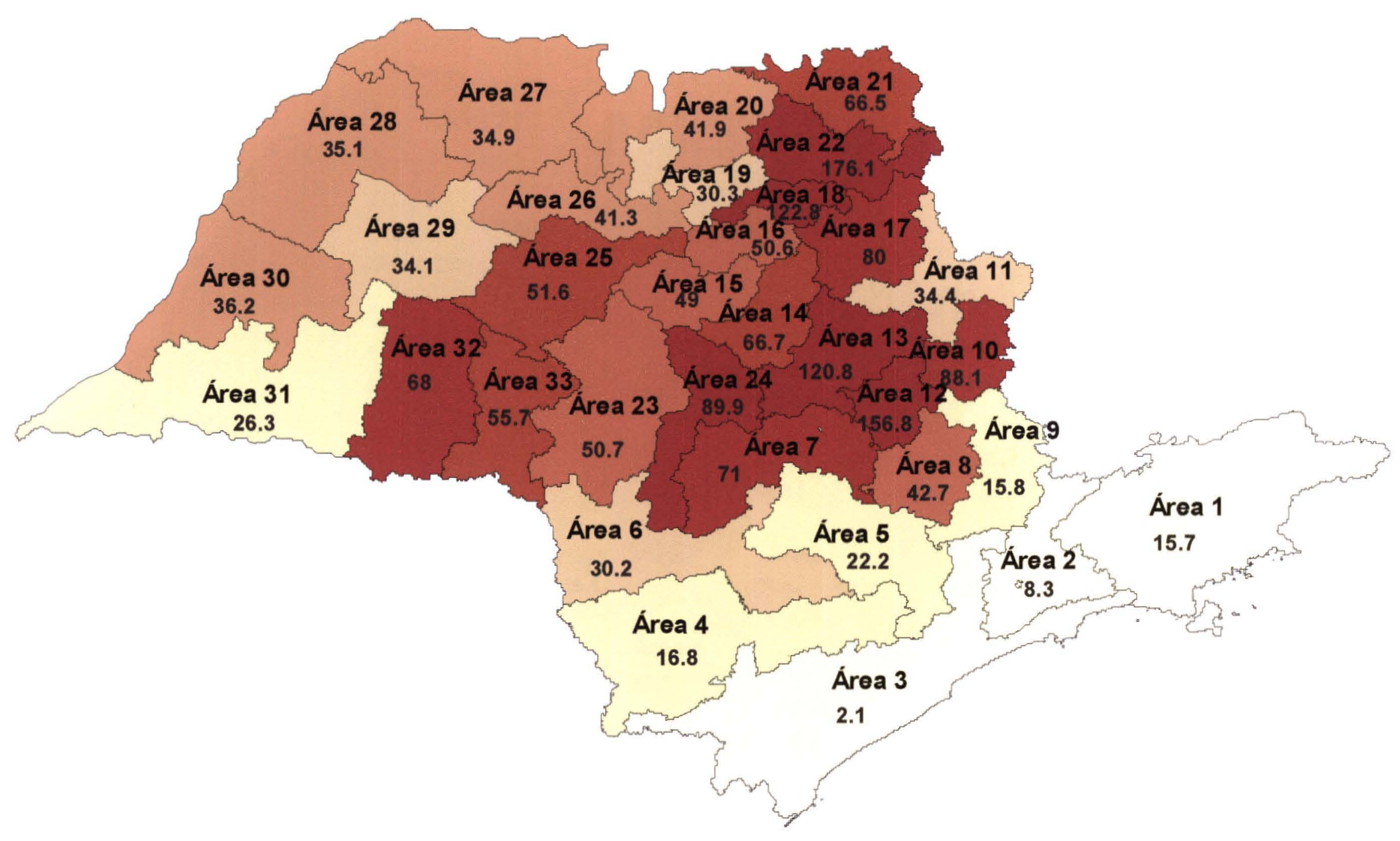


Figura 8

Taxa de Incidência Acumulada dos Registros de AT em Áreas Rurais

Municípios do Estado de São Paulo Agrupados em Áreas Elaboradas

1998

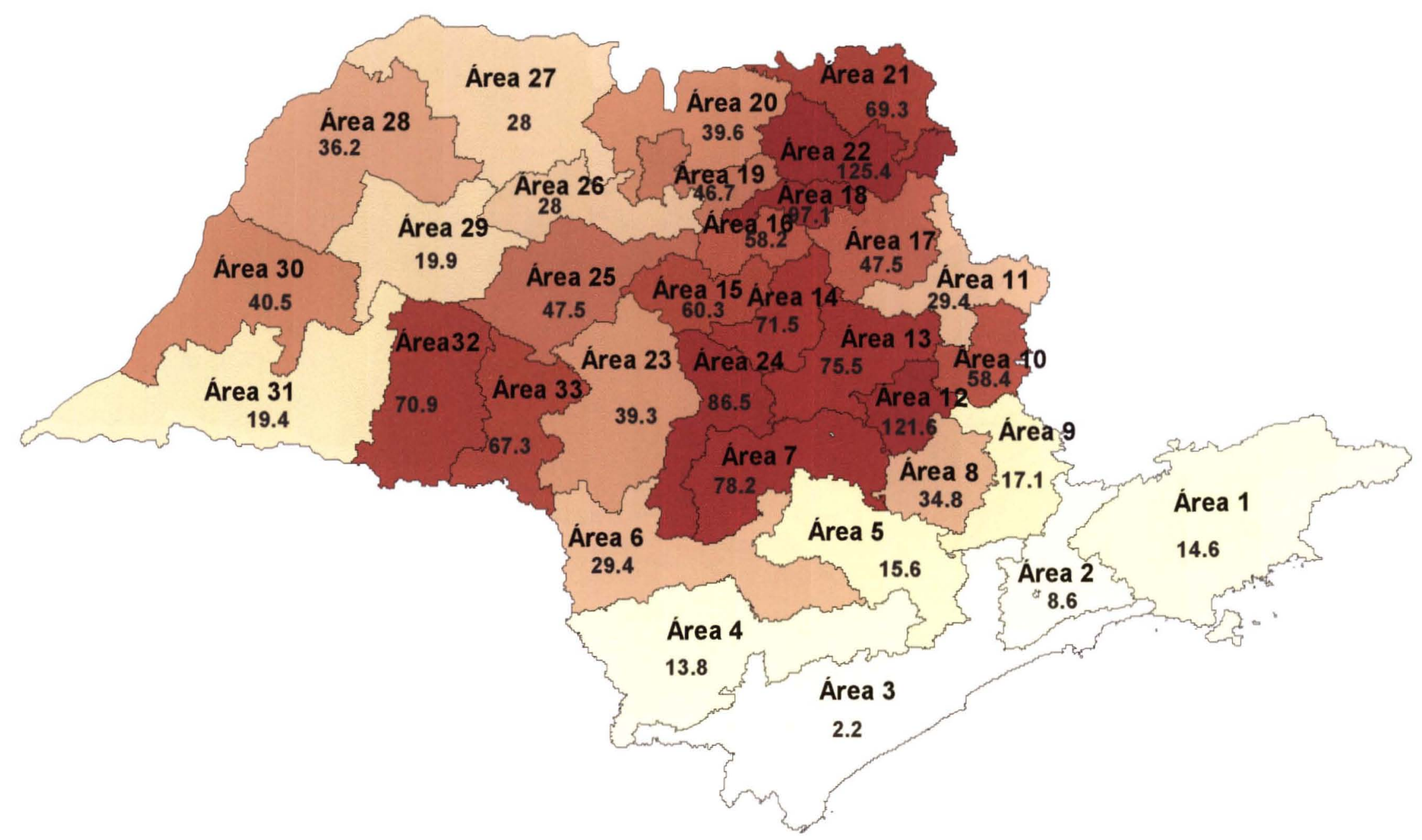


Figura 9

Taxa de Incidência Acumulada dos Registros de AT em Áreas Rurais

Municípios do Estado de São Paulo Agrupados em Áreas Elaboradas

1999

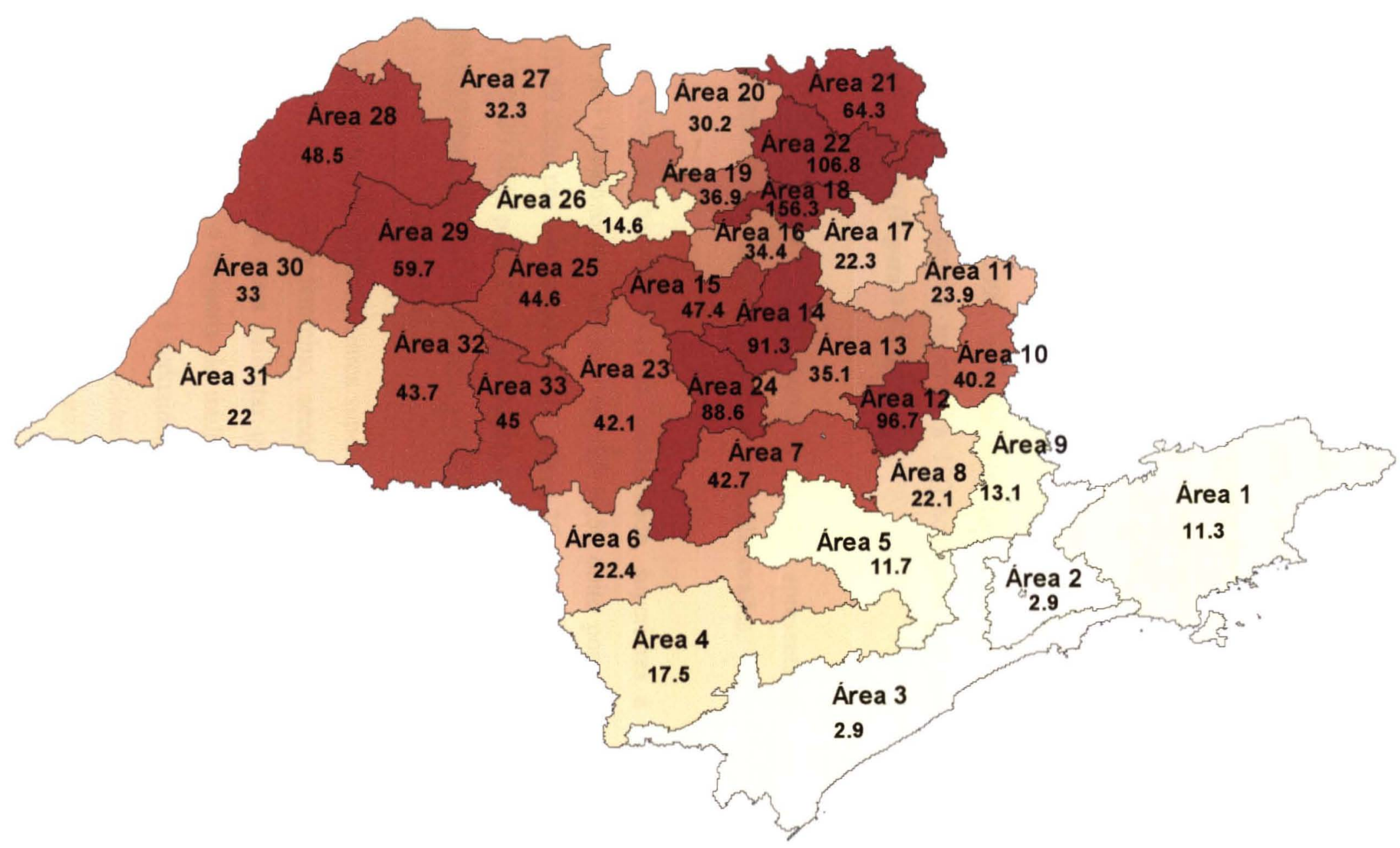


$\mathrm{O}$ ano de 1999 mantém a tendência de queda verificada no ano anterior e na mesma proporção de $12 \%$ para as taxas de incidência acumulada. Em relação a 1997, essa queda foi de quase $23 \%$. Por sexo, a queda foi maior para o feminino, igual a $26,4 \%$ (Tabela 18). Entre 1999, a incidência acumulada para o sexo feminino foi de 31,46 registros de AT por mil trabalhadoras. Superior ao total da população, o sexo masculino registrou, nesse ano, uma taxa de incidência acumulada de 45,12 (Tabela 18).

Segundo as áreas elaboradas, em 1999, somente duas (áreas 18 e 22) registraram uma taxa de incidência acumulada superior a 100 acidentes por mil trabalhadores para o total da população (Figura 9 e Tabela 18).

A taxa de mortalidade também por mil trabalhadores em 1997 apresenta-se baixa, tanto para o total do Estado de São Paulo como para as áreas elaboradas.

As áreas elaboradas com as maiores taxas de mortalidade, superiores à estadual de 0,11 óbito por mil trabalhadores, são as áreas: 27 (0,50 óbito por mil trabalhadores), a área 18 ( 0,49 óbito por mil trabalhadores), a área 25 (0,25 óbito por mil trabalhadores), a área 17 (0,20 óbito por mil trabalhadores) e áreas 4, 20, 21, $23 \mathrm{e}$ 29 , todas com uma taxa de 0,19 óbito por mil trabalhadores (Tabela 19).

A mais expressiva taxa de mortalidade e a única superior a um óbito por mil trabalhadores foi a da área 17 para o sexo feminino, sendo, inclusive, a única a registrar óbitos feminino por AT. Vale a pena salientar que este dado deve ser observado com cuidado, uma vez que o número de mulheres moradoras nesses municípios que trabalham com atividades rurais é reduzido, dessa forma um óbito pode ter um peso relevante, assim como o número de acidentes registrados, ou seja, essa informação deve ser vista com ressalvas, uma vez que pode ser fruto de variabilidade estatística. 
As áreas 18 e 27 registraram as mais elevadas taxas de mortalidade tanto para o total da população como para o sexo masculino, indicando que foi a área onde os registros de AT, provavelmente, foram mais graves, resultando em óbito (Tabela 19).

As taxas de mortalidade mostraram queda significativa entre 1997 e 1998, principalmente para o sexo feminino, diminuindo $50 \%$, entre esses dois anos (Tabela 19).

Em 1998, dentre as áreas a registrar óbitos, as menores taxas de mortalidade foram registradas nas áreas $6,7,16,21$ e 25, entretanto superiores à observada pelo total do Estado. Enquanto, as mais elevadas eram as áreas 1, 4, 5, 12, 13 e 22 para o total da população. Para o sexo masculino, todas as áreas onde ocorreram óbitos, os coeficientes de mortalidade foram superiores ao encontrado para o total do Estado, destacando-se as áreas: $1,4,5,12$ e 13 . Somente na área 7 houve morte feminina por AT (Tabela 19).

As taxas de mortalidade apresentaram pouca alteração entre 1998 e 1999, sendo que a feminina manteve-se em 0,02 óbito por mil trabalhadores, para o Estado de São Paulo (Tabela 19).

Neste ano, chama atenção as áreas 26 e 28 que registraram as maiores taxas de mortalidade em 1999, para o total da população e para o sexo masculino. Apenas a área 18 mostrou registro de óbitos femininos, sendo estes o mais alto de todo o Estado (Tabela 19). 
Tabela 19

Taxa de Mortalidade dos Registros de AT de Áreas Rurais do Estado de São Paulo 1997,1998 e 1999

\begin{tabular}{|c|c|c|c|c|c|c|c|c|c|}
\hline \multirow{3}{*}{$\begin{array}{c}\text { Áreas } \\
\text { Elaboradas }\end{array}$} & \multicolumn{9}{|c|}{ Taxa de Mortalidade (por mil trabalhadores) } \\
\hline & \multicolumn{3}{|c|}{1997} & \multicolumn{3}{|c|}{1998} & \multicolumn{3}{|c|}{1999} \\
\hline & Total & Masculino & Feminino & Total & Masculino & Feminino & Total & Masculino & Feminino \\
\hline Estado de São Paulo & 0,11 & $\mathbf{0 , 1 2}$ & $\mathbf{0 , 0 4}$ & 0,06 & 0,07 & $\mathbf{0 , 0 2}$ & $\mathbf{0 , 0 7}$ & $\mathbf{0 , 0 8}$ & 0,02 \\
\hline Área 1 & 0,10 & 0,10 & - & 0,19 & 0,20 & - & - & - & - \\
\hline Área 2 & - & - & - & - & - & - & - & - & - \\
\hline Área 3 & - & - & - & - & - & - & - & - & - \\
\hline Área 4 & 0,19 & 0,21 & - & 0,19 & 0,21 & - & 0,19 & 0,21 & - \\
\hline Área 5 & - & - & - & 0,19 & 0,22 & - & - & - & - \\
\hline Área 6 & 0,09 & 0,10 & - & 0,09 & 0,10 & - & 0,08 & 0,10 & - \\
\hline Área 7 & - & - & - & 0,09 & - & 0,52 & - & - & - \\
\hline Área 8 & 0,09 & 0,11 & - & - & - & - & - & - & - \\
\hline Área 9 & 0,10 & 0,11 & - & - & - & - & - & - & - \\
\hline Área 10 & 0,10 & 0,12 & - & - & - & - & - & - & - \\
\hline Área 11 & - & 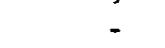 & - & - & - & - & - & - & - \\
\hline Área 12 & 0,09 & 0,11 & - & 0,18 & 0,22 & - & 0,18 & 0,22 & - \\
\hline Área 13 & - & - & - & 0,19 & 0,22 & - & - & - & - \\
\hline Área 14 & 0,10 & 0,13 & - & - & - & - & - & - & - \\
\hline Área 15 & 0,09 & 0,11 & - & - & - & - & - & - & - \\
\hline Área 16 & - & - & - & 0,09 & 0,11 & - & 0,09 & 0,10 & - \\
\hline Área 17 & 0,20 & - & 1,35 & 0,10 & 0,11 & - & 0,10 & 0,11 & - \\
\hline Área 18 & 0,49 & 0,57 & - & 0,10 & 0,11 & - & 0,09 & - & 0,63 \\
\hline Área 19 & - & - & - & & & & 0,09 & 0,11 & - \\
\hline Área 20 & 0,19 & 0,22 & - & 0,10 & 0,11 & - & 0,09 & 0,11 & - \\
\hline Área 21 & 0,19 & 0,22 & - & 0,09 & 0,11 & - & 0,18 & 0,21 & - \\
\hline Área 22 & - & - & - & 0,18 & 0,21 & - & 0,18 & 0,20 & - \\
\hline Área 23 & 0,19 & 0,23 & - & - & - & - & - & - & - \\
\hline Área 24 & 0,07 & 0,09 & - & - & - & - & - & - & - \\
\hline Área 25 & 0,27 & 0,32 & - & 0,09 & 0,11 & - & 0,09 & 0,10 & - \\
\hline Área 26 & - & - & - & - & - & - & 0,28 & 0,33 & - \\
\hline Área 27 & 0,50 & 0,54 & - & - & - & - & 0,10 & 0,11 & - \\
\hline Área 28 & - & - & - & 0,10 & 0,10 & - & 0,29 & 0,31 & - \\
\hline Área 29 & 0,19 & 0,22 & - & - & - & - & - & - & - \\
\hline Área 30 & - & - & - & 0,10 & 0,11 & - & 0,19 & 0,22 & - \\
\hline Área 31 & 0,09 & 0,10 & - & - & - & - & - & - & - \\
\hline Área 32 & 0,09 & 0,10 & - & - & - & - & 0,09 & 0,10 & - \\
\hline Área 33 & 0,25 & 0,31 & - & - & - & - & - & - & - \\
\hline
\end{tabular}

Nota: Inclui todos os registros existentes na Base de Acidentes do Trabalho no Meio Rural.

(-) Fenômeno inexistente

Com relação à taxa de letalidade, que mede o número de registros de óbitos decorrentes de AT pelo número de AT registrados, observa-se em 1997, a exemplo da mortalidade, maior relevância para o sexo masculino para o total do Estado. 
Neste ano, o sexo masculino apresenta dois óbitos por mil AT, ligeiramente superior à letalidade da população total $(1,98)$, enquanto o feminino obtém cerca de um óbito por mil acidentes.

Com exceção das áreas $10,12,14,15,24$ e 32 que mostraram taxas de letalidade inferiores à média estadual, as demais áreas registraram taxas acima, sendo as maiores encontradas nas áreas 27 e 4 (Tabela 20).

A área 17 foi a única a registrar óbitos femininos por AT, registrando uma relevante taxa de letalidade, de 37,0 óbitos por mil registros de AT. Enquanto a área 27 destacou-se com relação a letalidade do sexo masculino (Tabela 20).

A exemplo das taxas de mortalidade, a taxas de letalidade apresentaram tendência de queda entre 1997 e 1998, apresentando diminuição de quase 37\% para o total da população como para o sexo masculino, sendo que para o sexo feminino foi ainda maior $(41,9 \%)$ (Tabela 20$)$.

Em 1998, com relação à letalidade, destacam-se as áreas: 4 e 5, com valores superiores a 10 mortes por mil registros de AT, tanto para o total da população como para o sexo masculino. Somente a área 7 registrou letalidade para o sexo feminino, sendo que esta foi a maior observada em 1998, igual a 15,9 óbitos por mil registros de AT (Tabela 20).

Ainda com relação a 1998, as áreas com as mais baixas taxas (inferiores a dois óbitos por mil registros de AT) foram: 7, 12, 16, 18 (a menor), 21, 22 e 25 (Tabela 23), sendo que as menores taxas de letalidade do sexo masculino foram verificadas nas áreas $12,16,18,21$ e 22 (inferiores a dois óbitos por mil registros de AT) (Tabela 20).

No que se refere às taxas de letalidade em 1999, nota-se um aumento para o total da população e para o sexo masculino em cerca de $27 \%$ (Tabela 20). 
Chama atenção, neste período, a área 26 que registrou as maiores taxas letalidade para o total da população e para o sexo masculino. Apenas a área 18 mostrou registro de óbitos femininos (Tabela 20).

Tabela 20

Taxa de Letalidade dos Registros de AT de Áreas Rurais do Estado de São Paulo 1997,1998 e 1999

\begin{tabular}{|c|c|c|c|c|c|c|c|c|c|}
\hline \multirow{3}{*}{$\begin{array}{c}\text { Áreas } \\
\text { Elaboradas }\end{array}$} & \multicolumn{9}{|c|}{ Taxa de Letalidade (por mil Registros de AT) } \\
\hline & \multicolumn{3}{|c|}{1997} & \multicolumn{3}{|c|}{1998} & \multicolumn{3}{|c|}{1999} \\
\hline & Total & Masculino & Feminino & Total & Masculino & Feminino & Total & Masculino & Feminin \\
\hline Estado de Săo Paulo & 1,98 & 2,11 & 0,93 & 1,25 & 1,34 & 0,54 & 1,59 & 1,71 & 0,6 \\
\hline Área 1 & 6,33 & 6,45 & - & 13,33 & 13,79 & - & - & - & - \\
\hline Área 2 & - & - & - & - & - & - & - & - & - \\
\hline Área 3 & - & - & - & - & - & - & - & - & - \\
\hline Área 4 & 11,43 & 12,27 & - & 13,70 & 14,08 & - & 10,58 & 11,11 & - \\
\hline Área 5 & - & - & - & 11,90 & 13,42 & - & $\cdot$ & - & - \\
\hline Área 6 & 2,90 & 3,27 & - & 2,92 & 3,21 & - & 3,76 & 4,13 & - \\
\hline Área 7 & - & - & - & 1,19 & - & 15,87 & - & - & - \\
\hline Área 8 & 2,13 & 2,39 & - & - & - & - & - & - & - \\
\hline Área 9 & 6,10 & 7,30 & - & - & - & - & - & - & - \\
\hline Área 10 & 1,13 & 1,30 & - & - & - & - & - & - & - \\
\hline Área 11 & - & - & - & - & - & - & - & - & - \\
\hline Área 12 & 0,59 & 0,68 & - & 1,49 & 1,71 & - & 1,83 & 2,16 & - \\
\hline Área 13 & - & - & - & 2,48 & 2,74 & - & - & - & - \\
\hline Área 14 & 1,44 & 1,72 & - & - & - & - & - & - & - \\
\hline Área 15 & 1,86 & 2,09 & - & - & - & - & - & - & - \\
\hline Área 16 & - & - & - & 1,57 & 1,66 & - & 2,60 & 2,77 & - \\
\hline Área 17 & 2,48 & - & 37,04 & 2,04 & 2,29 & - & 4,27 & 4,63 & - \\
\hline Área 18 & 3,98 & 4,36 & - & 0,98 & 1,05 & - & 0,60 & - & 14,7 \\
\hline Área 19 & - & - & - & & & & 2,54 & 2,77 & - \\
\hline Área 20 & 4,62 & 4,91 & - & 2,40 & 2,53 & - & 3,11 & 3,33 & - \\
\hline Área 21 & 2,88 & 3,38 & - & 1,36 & 1,56 & - & 2,87 & 3,12 & - \\
\hline Área 22 & 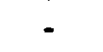 & - & - & 1,46 & 1,59 & - & 1,68 & 1,76 & - \\
\hline Área 23 & 3,77 & 4,61 & - & - & - & - & - & - & - \\
\hline Área 24 & 0,81 & 0,92 & - & - & - & - & - & - & - \\
\hline Área 25 & 5,16 & 5,94 & - & 1,85 & 2,13 & - & 1,95 & 2,13 & - \\
\hline Área 26 & 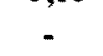 & - & - & 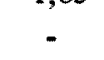 & - & - & 19,35 & 20,98 & - \\
\hline Área 27 & 14,29 & 15,43 & - & - & - & - & 3,03 & 3,18 & - \\
\hline Área 28 & - & - & - & 2,65 & 3,09 & - & 5,91 & 7,03 & - \\
\hline Área 29 & 5,63 & 6,21 & - & - & - & - & - & - & - \\
\hline Área 30 & - & - & - & 2,41 & 2,70 & - & 5,90 & 6,47 & - \\
\hline Área 31 & 3,34 & 3,66 & - & - & - & - & - & - & - \\
\hline Área 32 & 1,35 & 1,51 & - & - & - & - & 2,05 & 2,21 & - \\
\hline Área 33 & 4,44 & 5,27 & - & - & - & - & 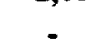 & 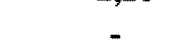 & - \\
\hline
\end{tabular}

Nota: Inclui todos os registros existentes na Base de Acidentes do Trabalho no Meio Rural. (-) Fenômeno inexistente 


\subsubsection{Cultura sucroalcooleira}

Tendo como referência a população trabalhadora de 10 a 69 anos residente no Estado de São Paulo ocupada no cultivo de cana-de-açúcar nas ocupações descritas no Capitulo Material e Método e contribuinte de Instituto de Previdência Social, foram calculados os coeficientes de incidência acumulada e mortalidade.

A avaliação dos registros de AT relacionados à cultura sucroalcooleira, entre 1997 e 1999 distribuídos por todo o Estado de São Paulo, corresponde à elaboração de seis áreas (Anexo 5) que seguiu o critério populacional estipulado no Capítulo Material e Método de agrupar os municípios com menos de 10 mil trabalhadores residentes envolvidos nesse cultivo.

Com taxas de incidência acumulada bem superiores às dos acidentes registrados no meio rural, a cultura sucroalcooleira apresenta para o Estado de São Paulo valores superiores a 100 registros por mil trabalhadores.

Com pequenas variações nesses anos, o Estado de São Paulo registra praticamente a mesma taxa de incidência acumulada em 1997 e 1999, sendo que a diferença entre estas é um acréscimo de apenas $1,1 \%$. Por sexo, as alterações ocorridas são distintas, enquanto o sexo masculino registra um pequeno crescimento de quase 4\% entre 1997 e 1999, o sexo feminino aponta uma queda de $18 \%$ nesse período (Tabela 21).

$\mathrm{O}$ ano de 1998 mostrou as mais baixas taxaș de incidência acumulada para o total do Estado de São Paulo, inclusive por sexo (Tabela 21)

Por áreas elaboradas, nota-se a mesma tendência entre 1997 e 1998, onde as mais altas taxas se concentram nas áreas 1 e 6 , sendo que a taxa de incidência mais elevada se concentrava na área 1 e a mais baixa na área 5. O ano de 1999 traz outro 
panorama, com relação à taxa mais elevada que "migra" para a área 6, que passa a registrar a mais elevada taxa de incidência (Figura 10 e Tabela 21).

Através da Figura 10 é possivel observar a evolução das taxas de incidência acumulada da cultura sucroalcooleira de 1997 a 1999 para as áreas elaboradas do Estado de São Paulo.

Com exceção das áreas 1 e 3 as demais registraram aumento em suas taxas de incidência entre 1997 e 1999, sendo as mais altas taxas de incidência encontradas nas áreas 1 e 4, esta última para o sexo feminino, ambas em 1997. A área 5 foi a única a apresentar taxas inferiores a 100 registros de AT por mil trabalhadores em todos os períodos (Tabelas 21).

O ano de 1998 mostrou as mais baixas taxas de incidência acumulada, mortalidade e letalidade do período, inclusive por sexo (Tabela 21).

\section{Tabela 21}

Taxa de Incidência Acumulada dos Registros de AT nas Culturas Sucroalcooleiras, segundo as Áreas Elaboradas do Estado de São Paulo. 1997, 1998 e 1999

\begin{tabular}{|c|c|c|c|c|c|c|c|c|c|}
\hline \multirow{3}{*}{$\begin{array}{c}\text { Áreas } \\
\text { Elaboradas }\end{array}$} & \multicolumn{9}{|c|}{ Taxa de Incidência Acumulada (por mil trabalhadores) } \\
\hline & \multicolumn{3}{|c|}{1997} & \multicolumn{3}{|c|}{1998} & \multicolumn{3}{|c|}{1999} \\
\hline & Total & Masculino & Feminino & Total & Masculino & Feminino & Total & Masculino & Feminino \\
\hline Estado de Sío Paulo & 109,01 & 112,52 & 86,28 & 102,86 & 108,27 & 67,88 & 110,16 & 116,30 & 70,56 \\
\hline Área 1 & 148,76 & 157,87 & 101,56 & 144,98 & 157,44 & 80,66 & 100,77 & 104,62 & 80,93 \\
\hline Área 2 & 104,41 & 114,34 & 50,63 & 116,09 & 127,54 & 54,29 & 108,66 & 116,60 & 65,93 \\
\hline Área 3 & 118,80 & 123,15 & 88,19 & 77,93 & 83,80 & 36,77 & 103,08 & 113,21 & 32,20 \\
\hline Área 4 & 91,52 & 88,95 & 116,61 & 100,84 & 102,48 & 84,92 & 123,77 & 129,44 & 68,45 \\
\hline Área 5 & 67,43 & 70,70 & 51,20 & 56,81 & 59,14 & 45,33 & 88,17 & 90,18 & 78,30 \\
\hline Área 6 & 124,41 & 121,23 & 152,84 & 122,75 & 120,64 & 141,69 & 138,15 & 141,11 & 111,51 \\
\hline
\end{tabular}

(-) Fenômeno inexistente

As taxas de mortalidade para o total do Estado de São Paulo registram entre 1997 e 1999, um pequeno aumento de $12 \%$, enquanto para os homens permaneceram 
praticamente a mesma. As mulheres registraram taxas de mortalidade somente em 1999 e no mesmo valor da registrada pelo sexo masculino (Tabela 22).

As áreas elaboradas a apresentarem as taxas de mortalidade mais elevadas foram as áreas 6 e 5 em 1997, a 4 em 1998 e, em 1999, novamente, as áreas 5 e 6 . A área 3 foi a única que registrou taxa de mortalidade feminina (Tabela 22).

Tabela 22

Taxa de Mortalidade dos Registros de AT nas Culturas Sucroalcooleiras, segundo as Áreas Elaboradas do Estado de São Paulo. 1997, 1998 e 1999

\begin{tabular}{|c|c|c|c|c|c|c|c|}
\hline \multirow{3}{*}{$\begin{array}{c}\text { Áreas } \\
\text { Elaboradas }\end{array}$} & \multicolumn{7}{|c|}{ Taxa de Mortalidade (por mil trabalhadores) } \\
\hline & \multicolumn{2}{|c|}{1997} & \multicolumn{2}{|c|}{1998} & \multicolumn{3}{|c|}{1999} \\
\hline & Total & Masculino & Total & Masculino & Total & Masculino & Feminino \\
\hline Estado de São Paulo & 0,09 & 0,10 & 0,07 & $\mathbf{0 , 0 8}$ & 0,10 & $\mathbf{0 , 1 0}$ & 0,10 \\
\hline Área 1 & - & - & - & - & 0,09 & 0,10 & - \\
\hline Área 2 & - & - & - & - & - & - & - \\
\hline Área 3 & 0,16 & 0,18 & 0,08 & 0,09 & 0,07 & - & 0,60 \\
\hline Área 4 & - & - & 0,24 & 0,26 & 0,08 & 0,09 & - \\
\hline Área 5 & 0,19 & 0,22 & - & - & 0,18 & 0,22 & - \\
\hline Área 6 & 0,20 & 0,22 & 0,10 & 0,11 & 0,19 & 0,21 & - \\
\hline
\end{tabular}

Nota: Não houve registro de óbitos femininos por AT em 1997 e 1998

(-) Fenômeno inexistente

Com relação à letalidade, verifica-se praticamente a mesma tendência observada na mortalidade para o Estado de São Paulo, com um pequeno aumento para o total da população e uma pequena redução para o sexo masculino (Tabela 23). As mulheres registraram taxas de letalidade somente em 1999, sendo que esta superou em $77 \%$ a taxa masculina (Tabela 23 ).

Em 1997, observa-se na área 5, a maior taxa de letalidade total e masculina. Em 1998, essa área não registra óbitos e a maior taxa de letalidade é observada na área 4. Entretanto, em 1999, a área 5 passa a registrar a mais elevada taxa de letalidade para a população total e masculina. Nesse ano, a área 3 registra a única taxa de letalidade do sexo feminino para a cultura sucroalcooleira (Tabela 23). 
Tabela 23

Taxa de Letalidade dos Registros de AT nas Culturas Sucroalcooleiras, segundo as Áreas Elaboradas do Estado de São Paulo. 1997, 1998 e 1999

\begin{tabular}{|c|c|c|c|c|c|c|c|}
\hline \multirow{3}{*}{$\begin{array}{c}\text { Áreas } \\
\text { Elaboradas }\end{array}$} & \multicolumn{7}{|c|}{ Taxa de Letalidade (por mil Registros de AT) } \\
\hline & \multicolumn{2}{|c|}{1997} & \multicolumn{2}{|c|}{1998} & \multicolumn{3}{|c|}{1999} \\
\hline & Total & Masculino & Total & Masculino & Total & Masculino & Feminino \\
\hline Estado de São Paulo & 0,79 & $\mathbf{0 , 8 8}$ & 0,68 & $\mathbf{0 , 7 5}$ & $\mathbf{0 , 8 8}$ & $\mathbf{0 , 8 2}$ & $\mathbf{1 , 4 6}$ \\
\hline Área 1 & - & - & - & - & 0,86 & 0,99 & - \\
\hline Área 2 & - & - & - & - & - & - & - \\
\hline Área 3 & 1,32 & 1,46 & 0,98 & 1,04 & 0,72 & - & 18,52 \\
\hline Área 4 & - & - & 2,35 & 2,55 & 0,63 & 0,66 & - \\
\hline Área 5 & 2,77 & 3,17 & - & - & 2,05 & $\mathbf{2 , 4 2}$ & - \\
\hline Área 6 & 1,58 & 1,80 & 0,79 & 0,90 & 1,39 & 1,52 & - \\
\hline
\end{tabular}

Nota: Não houve registro de óbitos femininos por AT em 1997 e 1998

(-) Fenômeno inexistente 


\section{Figura 10}

Taxa de Incidência Acumulada dos Registros de AT na Cultura Sucroalcooleira Municípios do Estado de São Paulo Agrupados em Áreas Elaboradas

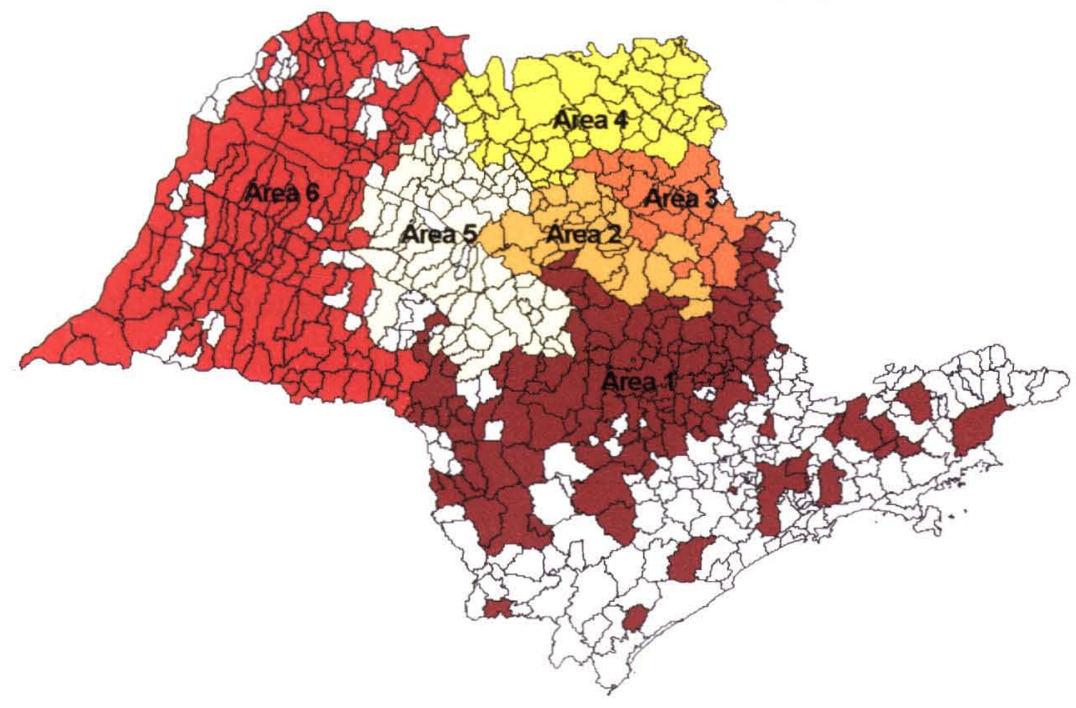

1997

Por mil trabalhadores

\begin{tabular}{|l|l|}
\hline & 0.00 \\
\hline$\square$ & 67.43 \\
\hline & 91.52 \\
\hline & 104.41 \\
\hline & 118.80 \\
\hline & 124.41 \\
$\square$ & 148.76
\end{tabular}

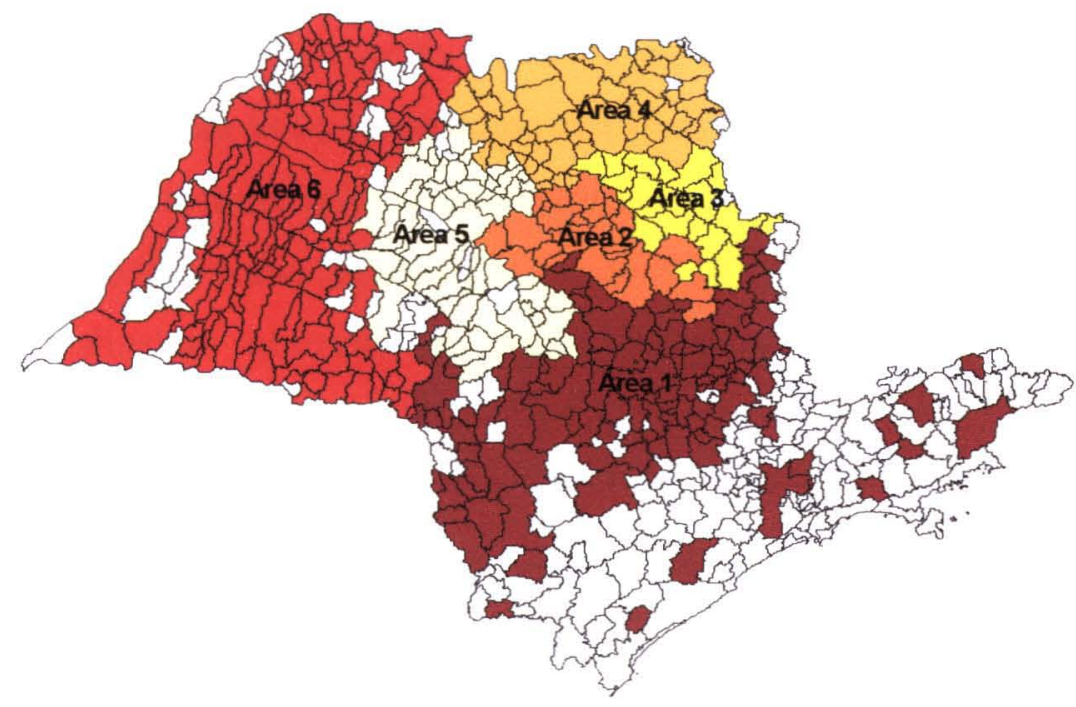

1998

Por mil trabalhadores 0.00 56.81

77.93

100.84

116.09

122.75

144.98

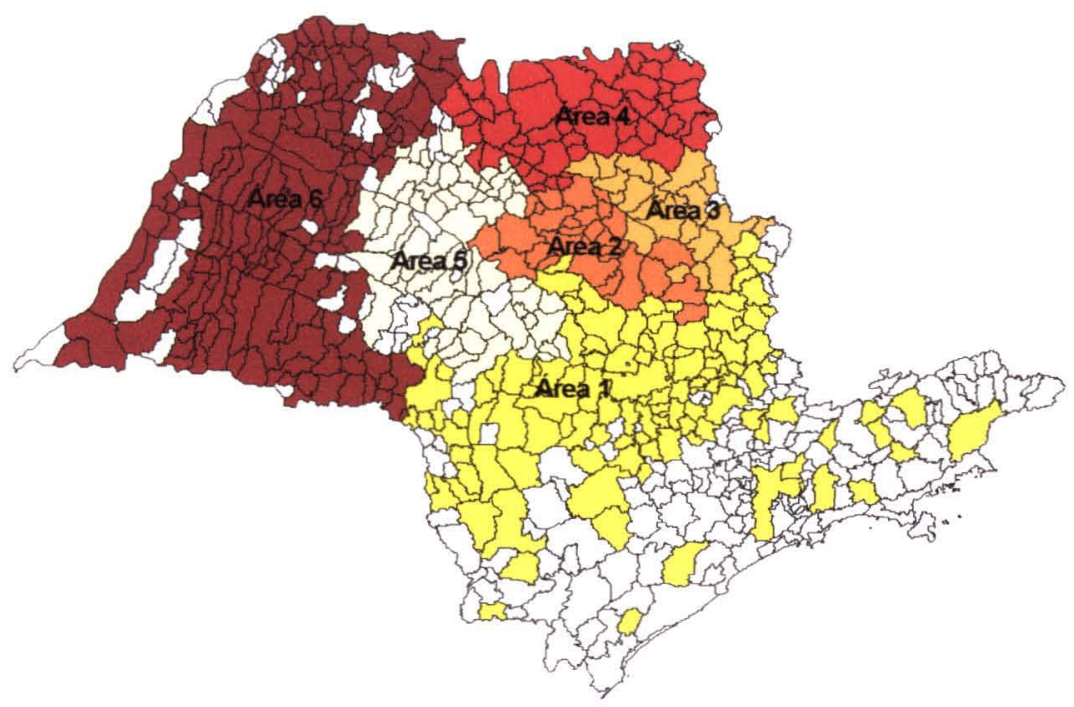

1999

Por mil tr abalhadores 0.00 88.17 100.77 103.08 108.66 123.77 138.15 


\subsubsection{Cultura de frutas cítricas}

Tendo como referência a população trabalhadora de 10 a 69 anos residente no Estado de São Paulo ocupada no cultivo de frutas cítricas nas ocupações descritas no Capitulo Material e Método e contribuinte de Instituto de Previdência Social, juntamente com os registros de AT, estimou-se as taxas de incidência acumulada e mortalidade.

$\mathrm{O}$ cálculo das taxas baseou-se nos registros de AT relacionados ao cultivo das frutas cítricas entre 1997 e 1999 distribuídos por todo o Estado de São Paulo em quatro áreas (Anexo 6).

Para a elaboração destas áreas, manteve-se o critério considerado para a formação das áreas rurais como das áreas da cultura sucroalcooleira (já referidas), de agrupar os municípios segundo o número de trabalhadores residentes envolvidos no cultivo das frutas cítricas (no mínimo $10 \mathrm{mil}$ ), sendo que neste caso a população trabalhadora utilizada no denominador das taxas de incidência acumulada $\mathrm{e}$ mortalidade variam entre 10 mil e 13 mil trabalhadores.

Com taxas de incidência acumulada, bem inferiores às registradas para os trabalhadores da cultura sucroalcooleira e as dos trabalhadores das áreas rurais, a cultura cítrica apresentou para o Estado de São Paulo entre 1997 e 1999 uma variação crescente das taxas de incidência acumulada para o total da população trabalhadora, enquanto, em 1997 a taxa era de 12,07 registros de acidentes por mil trabalhadores do cultivo de frutas cítricas residentes no Estado de São Paulo, em 1999 passa para 17,19 registros, representando um crescimento de $42,5 \%$. Por ano, nota-se um aumento no último período em 1999, sendo que o ano de 1998, apresenta uma taxa muito próxima a 1997 (Tabela 24). 
Por sexo, verifica-se a mesma tendência de aumento, com taxas mais relevantes em 1999. Entretanto, o sexo feminino se sobressai com um aumento de quase $71 \%$ entre 1997 e 1999 em suas taxas de incidência, de 11,6 registros de AT por mil trabalhadores do cultivo de frutas cítricas residentes no Estado de São Paulo passou a registrar em 1999 uma taxa de 19,9 registros, superior à masculina em praticamente $20 \%$ (Tabela 24 ).

Regionalmente, a área elaborada com a mais alta taxa de incidência acumulada nos três anos analisados foi a área 1, enquanto a menor taxa ocorreu, em 1997, na área 4 e em 1998 e 1999 na área 3 (Tabela 24 e Figura 11).

Todas as quatro áreas elaboradas registraram elevação nas taxas de incidência acumulada, entre 1997 e 1999 (Tabela 24).

A Figura 11 permite acompanhar a evolução das taxas de incidência de acidentes em trabalhadores da cultura de frutas cítricas de 1997 para as áreas elaboradas do Estado de São Paulo.

Tabela 24

Taxa de Incidência Acumulada dos Registros de AT nas Culturas de Frutas Cítricas, segundo as Áreas Elaboradas do Estado de São Paulo. 1997, 1998 e 1999

\begin{tabular}{|c|c|c|c|c|c|c|c|c|c|}
\hline \multirow{3}{*}{$\begin{array}{c}\text { Áreas } \\
\text { Elaboradas }\end{array}$} & \multicolumn{9}{|c|}{ Taxa de Incidência Acumulada (por mil trabalhadores) } \\
\hline & \multicolumn{3}{|c|}{1997} & \multicolumn{3}{|c|}{1998} & \multicolumn{3}{|c|}{1999} \\
\hline & Total & Masculino & Feminino & Total & Masculino & Feminino & Total & Masculino & Feminino \\
\hline Estado de São Paulo & 12,07 & 12,16 & 11,64 & 12,17 & 12,08 & 12,56 & 17,19 & 16,59 & 19,87 \\
\hline Área 1 & 25,33 & 27,37 & 17,76 & 23,93 & 24,18 & 23,01 & 28,66 & 28,24 & 30,18 \\
\hline Área 2 & 8,76 & 7,70 & 12,57 & 9,31 & 9,19 & 9,73 & 19,00 & 18,45 & 21,00 \\
\hline Área 3 & 8,53 & 8,75 & 7,13 & 6,12 & 6,45 & 4,10 & 10,06 & 9,82 & 11,52 \\
\hline Área 4 & 7,41 & 7,52 & 6,80 & 8,96 & 8,92 & 9,17 & 10,65 & 10,55 & 11,16 \\
\hline
\end{tabular}

(-) Fenômeno inexistente 
Com relação à taxa de mortalidade, pouco variou para o Estado de São Paulo, entre 1997 e 1998, para o total da população como para o sexo masculino, sendo que para o sexo feminino não houve registro de óbito por AT em nenhum dos anos. Segundo as áreas elaboradas em 1997, somente a área 2 apresentou registro de óbitos para o sexo masculino, enquanto em 1998 foi à área 1 (Tabela 25). No ano de 1999, não foi registrado nenhum óbito entre os trabalhadores envolvidos na cultura das frutas cítricas.

Tabela 25

Taxa de Mortalidade dos Registros de AT nas Culturas de Frutas Cítricas, segundo as Áreas Elaboradas do Estado de São Paulo. 1997, 1998 e 1999

\begin{tabular}{|c|c|c|c|c|}
\hline \multirow{3}{*}{$\begin{array}{c}\text { Áreas } \\
\text { Elaboradas }\end{array}$} & \multicolumn{4}{|c|}{ Taxa de Mortalidade (por mil trabalhadores) } \\
\hline & \multicolumn{2}{|c|}{1997} & \multicolumn{2}{|c|}{1998} \\
\hline & Total & Masculino & Total & Masculino \\
\hline Estado de São Paulo & $\mathbf{0 , 0 2}$ & 0,03 & 0,04 & 0,05 \\
\hline Área 1 & - & - & 0,16 & 0,21 \\
\hline Área 2 & 0,08 & 0,10 & - & - \\
\hline Área 3 & - & - & - & - \\
\hline Área 4 & - & - & - & - \\
\hline
\end{tabular}

Nota: Não houve registro de óbitos femininos por AT em 1997 e 1998

Em 1999, não houve nenhum registro de óbitos decorretntes de AT.

Quanto à taxa de letalidade, nota-se, entre 1997 e 1998, um aumento de cerca de $95 \%$ para a população total do Estado de São Paulo e $98 \%$ para o sexo masculino. Da mesma forma da taxa de mortalidade, somente as áreas selecionadas 2 e 1 apresentaram taxas de letalidade neste período, respectivamente (Tabela 26).

No ano de 1999, não foi registrado nenhum óbito entre os trabalhadores envolvidos na cultura das frutas cítricas. 
Tabela 26

Taxa de Letalidade dos Registros de AT nas Culturas de Frutas Cítricas, segundo as Áreas Elaboradas do Estado de São Paulo. 1997, 1998 e 1999

\begin{tabular}{|c|c|c|c|c|}
\hline \multirow{3}{*}{$\begin{array}{c}\text { Áreas } \\
\text { Elaboradas do } \\
\text { Estado de São Paulo }\end{array}$} & \multicolumn{4}{|c|}{ Taxa de Letalidade (por mil Registros de AT) } \\
\hline & \multicolumn{2}{|c|}{1997} & \multicolumn{2}{|c|}{1998} \\
\hline & Total & Masculino & Total & Masculino \\
\hline Estado de São Paulo & 1,78 & 2,16 & $\mathbf{3 , 4 6}$ & 4,26 \\
\hline Área 1 & - & - & 6,83 & 8,62 \\
\hline Área 2 & 8,70 & 12,66 & - & - \\
\hline Área 3 & - & - & - & - \\
\hline Área 4 & - & - & - & - \\
\hline
\end{tabular}

Nota: Não houve registro de óbitos femininos por AT em 1997 e 1998

Em 1999, não houve nenhum registro de óbitos decorretntes de AT.

(-) Fenômeno inexistente 
Figura 11

Taxa de Incidência Acumulada dos Registros de AT na Cultura de Frutas Cítricas Municípios do Estado de São Paulo Agrupados em Áreas Elaboradas
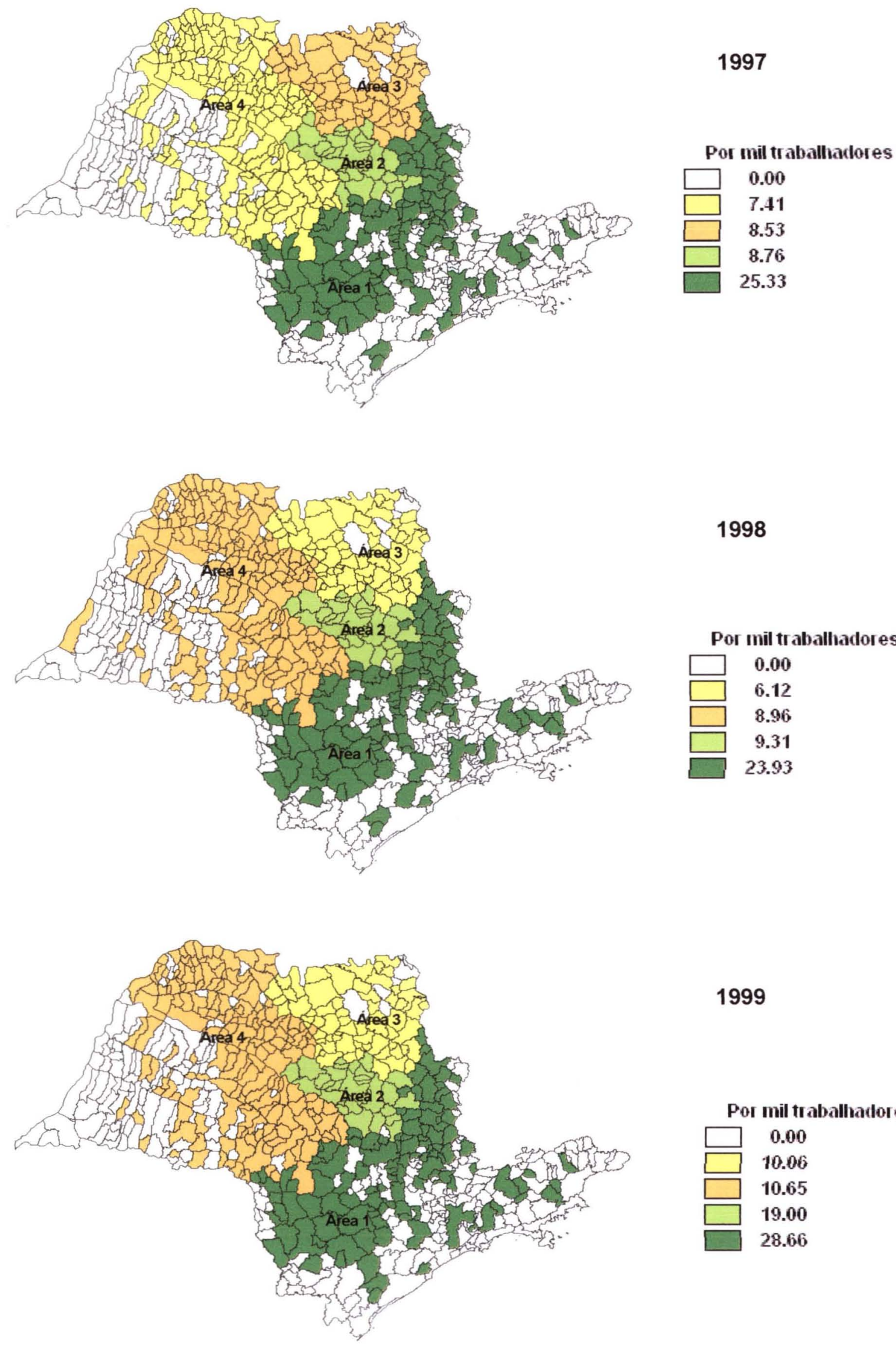

Por mil trabalhadores

0.00

6.12

8.96

9.31

23.93

0.00
10.06
10.65
19.00
28.66




\section{DISCUSSÃO}

\subsection{Tipo de estudo}

Este estudo descritivo de corte transversal, com informações referentes à distribuição dos registros de AT da população assegurada da Previdência Social, delineou áreas de maior ou menor incidência acumulada, mortalidade e letalidade para o meio rural e para as culturas sucroalcooleiras e cítricas.

Para o cálculo da incidência e da mortalidade utilizou-se um denominador de base populacional, obtido a partir do Censo Demográfico do IBGE, o qual mostrou ser uma alternativa possível para o cálculo de indicadores no estudo dos ATs.

A análise dos registros de AT, por pequenas áreas para duas das principais culturas do Estado de São Paulo, foi possível em virtude da base de dados da Fundação Seade/Fundacentro, da qual se originou esta pesquisa por conter informações desagregadas por municípios.

O levantamento de três anos consecutivos, também presente na base dados de referência, permitiu observar as ocorrências de mudanças desses eventos para o Estado de São Paulo, segundo as variáveis selecionadas.

\subsection{Fonte de análise}

Uma questão fundamental, no estudo de AT, diz respeito à fonte de dados utilizada. Há trabalhos baseados em pesquisa de campo onde os trabalhadores são entrevistados sobre o seu AT (BAPTISTELLA 1998; FARIA 2000; SANTANA et al 2003; BINDER e CORDEIRO 2003, entre tantos outros) e outros que se utilizam de registros administrativos. As principais fontes de informação dessa temática são: as Declarações de Óbitos e as Comunicações de Acidente do Trabalho - CAT 
(MACHADO e GOMEZ 1995; BERALDO 1993; WALDVOGEL 2002). Entre os diversos trabalhos que utilizam a CAT, encontram-se os de SANTOS et al 1990; BINDER et al 2001, SOUZA et al 2002, entre tantos outros.

No meio rural, algumas pesquisas utilizam dados primários, coletados de trabalhadores acidentados (VIEIRA et al 1983) mas, a grande maioria dos estudos, sobre AT rural, utilizou dados secundários obtidos de registros oficiais, tais como as comunicações de acidentes do trabalho - CAT's e os registros de hospitais ou os atestados de óbitos (COGBILL et al 1991; WALLER 1992; ALMEIDA et al 1993).

Apesar de ser considerada precária e problemática, por vários autores (POSSAS 1987; ALVES e LUCHESI 1992; HIRATA e SALERMO 1995; BINDER et al 2001; BINDER e CORDEIRO 2003) e possuir fins securitários, para o pagamento de indenizações aos trabalhadores acidentados, cadastrados junto a Previdência Social, as estatísticas oficiais servem de apoio para numerosos estudos epidemiológicos, apesar de não estabelecerem um panorama epidemiológico completo do que ocorre com a população trabalhadora (MELLO JORGE, GOTLIEB, LAURENTI 2001).

Mesmo tendo sua existência condicionada à geração de um beneficio, excluindo dessa forma, todos os trabalhadores do setor informal da economia (os militares estatutários, empregados domésticos e funcionários públicos civis), o registro de AT permite esboçar um perfil da situação, além de chamar a atenção para essa questão tão séria que atinge a classe trabalhadora que é o AT.

Este trabalho, de forma específica, serviu-se de um banco de dados, extraído das transcrições da CAT's, cujos acidentados declararam residir em municípios do Estado de São Paulo. As informações obtidas não são isentas de problemas, apontado por SALIM et al (2002) suas deficiências são referentes à representatividade e qualidade, derivadas da subnotificação. 
Com relação a sua representatividade e conhecendo a existência do subregistro, resultado da exclusão da população trabalhadora, anteriormente descrita, tentou-se, através do Banco Multidimensional de Estatística - BME do IBGE, averiguar a extensão destes registros, junto à população residente, no Estado de São Paulo, declarada envolvida em atividades do setor primário da economia brasileira (como descrito no Capítulo Material e Método).

Para tal, comparou-se a população trabalhadora estimada, que serviu de denominador nos indicadores das taxas de incidência acumulada e da mortalidade por AT, com uma população trabalhadora de 10 a 69 anos, residente no Estado de São Paulo, contribuinte ou não de previdência oficial também estimada, obtida por meio do BME.

Entre 1997 e 1999, os dados obtidos mostraram que, em média, 48\% da população trabalhadora, ocupada em atividades nurais, se encontrava ligada ao sistema previdenciário e, por isso, tinha acesso a um registro oficial de seu AT. Esta proporção encontra-se, um pouco acima da apontada por PASTORE (2000), para a força de trabalho brasileira, segundo o qual, apenas $43 \%$ da força de trabalho está vinculada ao sistema previdenciário, o restante estaria no mercado informal.

Por tipo de cultivo, essa proporção chega a alcançar, em média, para a canade-açúcar, 84\% da população ocupada, entre 1997 e 1999. Na verdade, 84\% dos trabalhadores ocupados nesse cultivo poderiam notificar um AT, junto à Previdência Social, através da CAT. Com uma proporção menor de 59\%, o cultivo das frutas cítricas também registrou um percentual superior ao encontrado, para as ocupações em áreas rurais, de trabalhadores ocupados, vinculados a algum sistema previdenciário.

É importante salientar que a maioria dos empregados em atividades agrícolas, no Estado de São Paulo, tanto homens como mulheres, é composta por trabalhadores permanentes, perfazendo mais de $60 \%$. Segundo dados da Tabulação Especial da PNAD, de 1995-1999 do IBGE, as mulheres correspondiam a um percentual de 
$69,2 \%$, em 1995, reduzindo para 60,8\%, em 1999.Enquanto que, para os homens, esse percentual pouco se alterou, de 62,4\%, em 1995, passou para 62,8\%, em 1999 (FUNDAÇÃO SEADE 2001a).

A arregimentação de trabalhadores temporários ou avulsos, para os períodos de colheita, são comuns. No Estado de São Paulo, muitas usinas sucroalcooleiras chegam a terceirizar, de $30 \%$ a $40 \%$, de sua força de trabalho (REVISTA PROTEÇÃO 2003).

Além da parcialidade da cobertura (que capta somente os inseridos no trabalho formal), outras limitações da CAT devem ser mencionadas: uma parte dos acidentes ocorridos com os trabalhadores formais podem não estar sendo notificados junto à Previdência Social. Estudos apontam que, no Brasil, há sub-notificação desses acidentes, particularmente, dos de menor gravidade, considerados mais leves (BINDER e CORDEIRO 2003; WÜNSCH FILHO 1995; CARMO et al 1995; ALVES e LUCHESI 1992; RIBEIRO e LACAZ 1984). Embora questionáveis, as CAT's servem de base para estudos epidemiológicos.

\subsection{Vantagens e desvantagens da utilização do Banco Seade/Fundacentro}

A grande vantagem do banco de dados sobre AT em áreas rurais paulistas da Fundação Seade/Fundacentro, no qual este exercício de pesquisa teve como referência, é a dimensão geográfica que abrangeu todo o Estado de São Paulo e o universo das atividades que abarcou todas as atividades desenvolvidas em áreas rurais, possibilitando a elaboração de áreas de taxas de incidência acumulada e de mortalidade por AT.

Deve-se salientar que os estudos e a disponibilidade de dados sobre o tema quando realizados, tais como os trabalhos de LOPES (1982), de ALESSI e NAVARRO (1997), FERREIRA et al (1998), SCOPINHO et al (1999), CORRÊA 
FILHO (1994a), entre outros, importantes e fundamentais, são específicos a determinadas áreas ou a estudos de casos.

Outra vantagem desse banco refere-se a forma criteriosa de como foi elaborado a coleta, com busca ativa e manual dos registros, o que garantiu com que nenhuma CAT fosse perdida; fidedignidade na transcrição da CAT, recorrendo a outros documentos que acompanhavam o processo e que podiam auxiliar no preenchimento das informações. Vantagem também na qualidade dos dados obtida pelas freqüentes consistências. Essa base foi totalmente liberada, não sendo vedada para análise nenhuma variável.

A grande desvantagem observada nesse banco, diz respeito à codificação da variável Descrição (Codificação) do $A T$, que partindo de uma codificação utilizada internacionalmente, a CID, ampliou esses códigos, objetivando identificar e detalhar toda gama de informações encontradas na CAT. Entretanto, este detalhamento não seguiu nenhum padrão de codificação utilizado em estudos de AT, acabando por misturar na mesma variável causa externa e natureza da lesão.

\subsection{Vantagens e desvantagens do banco utilizado nessa pesquisa}

A grande vantagem foi o cuidado na classificação dos registros de AT das culturas sucroalcooleiras e cítricas, o que permitiu identificar cerca de $43 \%$ dos acidentes registrados em área rural do Estado de São Paulo, como de acidentes ocorridos na cultura sucroalcooleira e $4 \%$ da cultura de frutas cítricas.

Se para essa classificação fosse considerado apenas os eventos codificados pela variável Ramo de Atividade, ligados ao cultivo de cana-de-açúcar ou ao cultivo de frutas cítricas, perder-se-ia eventos, uma vez que nessa categoria a base original apresentava cerca de $30 \%$ de seus eventos codificados como cultivo de cana-deaçúcar e somente $2 \%$ como de cultivo de frutas cítricas. 
Se o critério utilizado fosse a variável Ocupação, a situação seria mais crítica, uma vez que a maioria das categorias profissionais dos trabalhadores são preenchidas de forma bem ampla como: trabalhadores rurais e rurícolas, não especificado a que cultura trabalhavam.

Dessa forma, a separação e a codificação das sub-bases: sucroalcooleira e cítrica levando em consideração as variáveis: Ramo de Atividade, Ocupação, Município de ocorrência do acidente, Tipo de acidente e Agente causador, garantiu uma melhor qualidade a esta base.

Outra vantagem foi a preocupação em averiguar o município de ocorrência do acidente identificado como ignorado, buscou-se resolver essa situação através das variáveis Município de Residência do Acidentado, e Endereço da Prestadora de Serviço (Empresa/Fazenda) localizado no Estado de São Paulo. Essas medidas garantiram a consolidação dos dados.

A desvantagem - perdeu-se muito tempo na realização da separação da base nas sub-bases: sucroalcooleira e cítrica, como na verificação e/ou recodificação de algumas variáveis (como Faixa Etária - por exemplo), o que reduziu consideravelmente o cruzamento e análise de variáveis importantes presentes na base de dados da Fundação Seade/Fundacentro, como por exemplo, as variáveis: Horas Trabalhadas (quantas horas de trabalho ocorreu o AT) e Duração do Tratamento (quantidade de dias provável para duração do tratamento).

\subsection{Variáveis de estudo}

5.5.1 Distribuição dos registros e AT segundo o tipo de acidente

Perfazendo entre $80 \%$ e $93 \%$ dos ATs registrados em áreas rurais e nas culturas sucroalcooleiras e das frutas cítricas, os acidentes-tipo, ou seja, aqueles 
decorrentes de atividade profissional desempenhada pelo trabalhador representaram o principal tipo de acidente notificado na Previdência Social entre 1997 e 1999.

As informações disponiveis sobre registro de AT apontam o predomínio dos acidentes-tipo. Confirmado pelas estatísticas oficiais e por diversos estudos (BINDER et al 2001; MACHADO e GOMEZ 1994; SANTOS et al 1990), os acidentes-tipo atingem toda os trabalhadores, destacando-se com os maiores percentuais.

Merece destaque o aumento percentual dos acidentes de trajeto e das doenças do trabalho nas estatísticas oficiais entre 1970 e 1997, fato que se acentuou particularmente a partir de 1990.

Nesta pesquisa, o aumento dos acidentes de trajeto mostrou-se de forma explícita entre os registros de AT da cultura das frutas cítricas entre 1997 e 1999, ocorrendo também, em menor escala, na cultura sucroalcooleira.

Uma das razões para este aumento foi o fato de haver deslocamentos cada vez mais freqüentes dos trabalhadores rurais entre suas residências e o local de trabalho (BALSADI, BORIN e JULIO 2001). Como resultado da valorização das terras, os trabalhadores foram expulsos de sua casa e obrigados a migrarem para as cidades ou áreas rurais mais distantes de seu local de trabalho (ALESSI e NAVARRO 1997). A viagem realizada diariamente pelo trabalhador de sua residência ao local de trabalho pode durar várias horas, sendo comum o fato que em muitas vezes o trabalhador não tem conhecimento onde irá trabalhar, se dentro do município que reside ou nos municípios vizinhos, pois as áreas de cultivo das usinas atingem grandes extensões de terra (FUNDACENTRO 1998).

Esses deslocamentos longos são agravados pelas péssimas condições de transporte e das estradas, que em sua maioria é realizado em estradas vicinais em 
mau estado de conservação (NEVES 1994), aumentando a probabilidade de acidentes de trajeto.

Com relação ao baixo número de registros referentes às doenças do trabalho deve-se salientar a existência de diferentes filtros que tornam moroso o registro junto a Previdência Social, como: a presença ou não de sintomas iniciais da doença, à procura por profissionais capaz de fazer o diagnóstico da patologia e seu nexo causal com o trabalho, e o encaminhamento deste para a Previdência que confirmará ou não o nexo causal, por meio do perito.

Vale ressaltar que muitas doenças originadas no trabalho são percebidas em estágios avançados (MINAYO-GOMEZ e THEDIM-COSTA 1997), pois algumas em suas fases iniciais apresentam sintomas comuns a outras patologias, tornando-se dificeis de serem identificados os processos que as geraram e dificultando seu nexo causal (MINISTÉRIO DA SAÚDE 2001). MINAYO-GOMEZ e THEDIM-COSTA (1997), salientam que à passagem dos trabalhadores por processos produtivos diversos, pode mascarar nexos causais e diluir a possibilidade de estabelecê-los.

\subsubsection{Distribuição dos registros de AT segundo a conseqüência do acidente}

Outro fator observado nessa pesquisa e condizente às estatísticas oficiais é a imensa proporção de acidentes que tiveram como consequeência o afastamento do trabalhador de suas atividades laborais por um periodo de tempo determinado, voltando a trabalhar depois da alta. A incapacidade temporária que gera afastamento, pode afastar o trabalhador por um período inferior ou superior a 15 dias. $O$ afastamento com menos de 15 dias não gera beneficios previdenciários, sendo responsável pela remuneração da vítima a empregadora, já nos afastamentos superiores a este periodo a Previdência Social assume os encargos, gerando beneficio previdenciário.

Tanto a incapacidade permanente ou invalidez, como os óbitos, outras conseqüências do AT apareceram em baixo percentual juntos, não alcançando o 
patamar de $1 \%$ dos registros de AT notificados e coletados entre 1997 e 1999 na Previdência Social.

Segundo o tipo de cultura, essa variável apresentou tendência diferenciada, para a cultura sucroalcooleira, os acidentes fatais e as conseqüências permanentes apresentaram crescimento em número absoluto e relativo; enquanto para os registros de acidentes da cultura de frutas citricas o aumento só foi observado entre as conseqüências permanentes, consideradas mais graves, sendo que não houve nenhum registro de óbito em 1999. Quanto aos registros de AT em área rural verificou decréscimo em seus números absolutos como relativos. Entretanto, apesar de reduzidas estas proporções são preocupantes.

Em levantamento realizado por LUCCA e MENDES (1993), os óbitos e as incapacidades permanentes mantiveram-se estáveis ou cresceram ano a ano tanto em números absolutos como relativos, para o Brasil, durante toda a década de 1980. Esses autores salientam que como os óbitos, a incapacidade permanente é mais dificil de sofrer subnotificação do ponto de vista previdenciário (LUCCA e MENDES 1993).

5.5.3 Distribuição dos registros de AT das culturas suctoalcooleira e cítrica segundo tipo e conseqüência

Analisando os registros de AT das culturas sucroalcooleira e cítrica, com relação ao tipo e conseqüência do AT, verifica-se a importância proporcional dos óbitos nos acidentes de trajeto, apesar de numericamente inferiores. Um dos motivos que talvez explique essa importância seja o fato já apontando por WALDVOGEL (2001), que os acidentes do trajeto por serem mais violentos, resultam mais em mortes.

A ocorrência de óbitos por acidentes de trajeto somente na cultura sucroalcooleira, pode sugerir que estes sejam decorrentes do fato dessa cultura 
possuir áreas de plantio extensas (FUNDACENTRO 1998), obrigando os trabalhadores a se locomoveram a longas distâncias, expondo-se mais.

\subsubsection{Distribuição dos registros de AT segundo o sexo do acidentado}

Dimensões importantes nos estudos dos Ats como o sexo do acidentado e a distribuição etária proporcionam a descrição do perfil da população exposta. Apesar da diminuição dos postos de trabalho no meio rural ocorrida em todo País, já a partir da década de 1980, a ocupação no meio rural ainda é elevada (DIEESE 2001). Destes postos de trabalho, a maioria é preenchida pelo sexo masculino. Segundo as Tabulações Especiais da PNAD do IBGE, dos ocupados no setor agrícola, residentes rurais no Estado de São Paulo em 1999, 77,4\% eram homens e 22,6\% eram mulheres (FUNDAÇÃO SEADE 2001a).

Em que pese, mais uma vez, a questão do vínculo formal, ou seja, o trabalhador com carteira assinada e direitos previdenciários garantidos, os dados mostram por sexo, uma diminuição maior da carteira assinada para o sexo feminino entre os empregados agrícolas permanentes entre 1995 e 1999, de 64,0\% passou para $54,8 \%$. Entre os homens, a queda foi menor de $60,1 \%$ para $59,8 \%$, respectivamente (FUNDAÇÃO SEADE 2001a).

Com referência aos ATs, as estatísticas apontam que as mulheres têm menor risco para os acidentes fatais ou não, em relação aos homens, inclusive em países do primeiro mundo, como nos Estados Unidos, onde grande parte das profissões registrou um número maior de acidentes do sexo masculino (BIDDLE e BLANCIFORTE 1999). Na literatura brasileira especializada diversos são os estudos em que os homens representam a grande parte dos ATs observados (SANTANA et al 2003; BINDER e CORDEIRO 2003; RIBEIRO 2000, SANTOS et al 1990, entre outros).

Numericamente menos relevantes tanto para as áreas rurais como para as culturas sucroalcooleiras e cítricas, os acidentes femininos foram proporcionalmente 
maiores para as trabalhadoras do cultivo de frutas cítricas. A cultura sucroalcooleira se aproximou mais dos acidentes registrados em áreas rurais, apesar dessa apresentar queda em suas proporções em 1998 e 1999.

A cultura cítrica apresentou uma razão entre os sexos menor em relação à sucroalcooleira e à área rural, enquanto que em média foram registrados quatro ATs do sexo masculino para um feminino na cultura de frutas cítricas, essa média pulou para 10 acidentes masculinos para um feminino na sucroalcooleira e oito para as áreas rurais.

Entretanto, deve-se salientar que o fato dos trabalhadores masculinos apontarem uma quantidade de registros de AT superior ao feminino pode significar apenas que estes se encontram em número maior no mercado de trabalho, uma vez que as oportunidades de emprego são majoritariamente masculinas na sociedade brasileira (SANTOS et al 1990), com relação às atividades rurais, sabe-se que o volume de homens é mais elevado.

Outra hipótese que poderia ser cogitada é que os homens estariam submetidos a atividades com maior risco do que as mulheres, entretanto para a cultura sucroalcooleira como das frutas cítricas isso não se observa no que diz respeito ao corte e colheita manual. Com relação à divisão sexual do trabalho, ela não está presente no corte manual da cultura sucroalcooleira, os dois sexos participam de todas as etapas de trabalho, desde o preparo do solo, plantio, ao corte e distribuição de pesticidas. No que tange à cítrica, somente no repasse do pomar (quando o trabalhador retornar ao pomar para colher os frutos que não estavam maduros na época da primeira colheita), ocorre uma divisão sexual do trabalho, nas demais etapas do trabalho tanto homens como mulheres executam a mesma atividade (BAPTISTELLA 1998). 
5.5.5 Distribuição dos registros de AT das culturas sucroalcooleira e cítrica segundo tipo e sexo

Por tipo de acidente, observa-se proporcionalmente que a maioria dos acidentes-tipo, de trajeto e as doenças do trabalho atingem mais o sexo masculino, sobretudo os acidentes-tipo. Resultado coerente com fato que há mais homens no mercado formal de trabalho rural (FUNDAÇÃO SEADE 2001a).

Com relação à superioridade proporcional dos acidentes-tipo atingindo mais o sexo masculino é confirmada por outros levantamentos, WALDVOGEL (2002) em sua tese de doutorado sobre acidentes do trabalho fatais, conclui que os homens estão mais sujeitos aos acidentes-tipo que as mulheres.

Entretanto, observa-se que as doenças do trabalho e os acidentes de trajeto tem participação relevante entre as mulheres, sobretudo entre as trabalhadoras das frutas cítricas, na qual é constatado um grande número de mulheres (SILVA 2000).

Na cultura sucroalcooleira, ocorre uma significativa participação das doenças do trabalho no sexo feminino. Esta é uma atividade que exige grande força de trabalho para todo os trabalhadores envolvidos independente do sexo, e apesar de estarem em desvantagem quantitativa, muitas vezes, as mulheres não perdem para os homens em desempenho. Em um estudo realizado numa usina do interior paulista, foi constatado que o desempenho feminino no canavial é alto, enquanto os homens apresentavam rendimento de 9,8 toneladas per capita por dia, as mulheres ficavam em torno de 12,6 toneladas (REVISTA PROTEÇÃO 2003), esse alto desempenho obriga as mulheres a realizar um excesso de movimentos que podem acarretar em sérias doenças. 
5.5.6 Distribuição dos registros de AT segundo faixa etária

Outra fundamental dimensão para a caracterização do perfil da população acidentária é a distribuição por idade. É semelhante para os registros de AT das áreas rurais e da cultura sucroalcooleira, pois ambas apresentaram uma concentração de acidentes nas idades mais jovens.

Para o corte da cana-de-açúcar, em geral, os empregadores priorizam na hora da contratação os trabalhadores mais jovens em razão da produtividade, que com a idade tende a diminuir “(...) boa parte deles tem 18, 20 anos e a produtividade é reduzida depois que passam dos 40" (REVISTA PROTEÇÃo 2003, p.36).

Segundo SILVA (2000), as usinas sucroalcooleiras apresentam discriminação etária. A idade exigida para contratação vai até os 25 anos. Isto corrobora as características desta produção, baseada, sobejamente na exploração da força de trabalho, necessitando de uma mão-de-obra dotada de muita energia.

Distintamente a cultura das frutas cítricas apresenta uma distribuição específica com participação de registros de AT em idades mais avançadas. Resultado da maior presença desse grupo etário mais velho. Autores como BAPTISTELLA (1998, p.72) já mostraram que “(...) o trabalho de colheita propicia empregos a pessoas na terceira idade, não sendo comum nos setores secundário e terciário da economia formal".

\subsubsection{Distribuição dos registros segundo os menores de 18 anos}

No que tange à informação referente à presença de registros de AT envolvendo menores de idade trabalhando no meio rural, assim como nas culturas sucroalcoleiras e cítricas, sinaliza-se um tema polêmico que não poderia deixar de ser mencionado. Tem-se conhecimento da utilização da força de trabalho infantil e adolescente nessas culturas por textos, revistas e trabalhos de levantamento de campo 
(GOMES et al 2001), entretanto sabe-se que por lei o uso da força de trabalho infantil é proibido.

A Constituição Federal Brasileira de 1988 proibia o trabalho para os menores de 14 anos, ressalvando para aprendizes de 12 a 14 anos. A partir de dezembro de 1998, a emenda Constitucional $n^{\circ}$. 20 alterou tal limite, estabelecendo a idade minima para início do trabalho aos 16 anos, exceção ao aprendiz, que seria a partir dos 14 anos.

Na última década do século $\mathrm{XX}$ o trabalho infantil foi proibido (o Brasil ratificou as duas Convenções da OIT sobre o tema - $\mathrm{n}^{\circ} 138$, Idade Mínima para o Trabalho e $n^{\circ} 182$, Piores Formas de Trabalho Infantil) e vários programas de governos e ações de entidades não-governamentais foram implantados, transformando o Brasil em modelo para muitos países por sua redução significativa do número de crianças e adolescentes trabalhadores, com idade entre cinco e 17 anos, entre 1992 e 2001, que passou de 8,4 milhões para 5,4 milhões (OIT 2005).

O trabalho no campo pode ser especialmente nocivo para crianças e adolescentes, tanto por sua natureza, muitas vezes penosa, perigosa ou insalubre, como pelas condições em que é exercido. Esses menores são atingidos especialmente na saúde, ou seja, em seu desenvolvimento físico e psicológico e em suas possibilidades de educação, prejudicando também seu crescimento intelectual e social (DIEESE 2001). O National Institute for Occupational Safety and Health NIOSH estima que para os trabalhadores agricolas entre 15 e 17 anos de idade, os riscos de sofrer algum tipo de lesão fatal no trabalho é quatro vezes maior a de outras atividades profissionais (NIOSH 2003).

A existência de menores no mercado de trabalho está presente no mundo todo, nos Estados Unidos este fato é observado em mercearias, fábricas e no campo (COOPER et al 1999). 
Segundo a NIOSH (2003), a agricultura foi responsável por $42 \%$ das mortes relacionadas ao trabalho em adolescentes do mundo entre 1992 e 2000 , sendo que destes trabalhadores, a metade tinha menos de 15 anos de idade.

Essa mesma Instituição estimou que em 1998, cerca de 8.400 crianças e adolescentes sofreram AT nas fazendas dos Estados Unidos e que mais de dois milhões de jovens com menos de 20 anos de idade são expostos a perigos ligados ao meio rural (NIOSH 2001).

Na Austrália MANDRYK e HARRISON (1998), em estudo sobre mortalidade por AT entre 1982 e 1984, encontraram 4\% de óbitos de menores de 15 anos.

Em trabalho realizado por GOMES et al (2001), o corte de cana para crianças e adolescentes é uma atividade insalubre, que pode provocar doenças ocupacionais e AT em razão do desgaste físico e mental.

Nesse sentido, o trabalho na cultura da cana-de-açúcar, do sisal e da erva mate, assim como nas carvoarias, nas cerâmicas e olarias, na produção de calçados, nas serrarias, na indústria moveleira e nas madeireiras, entre várias outras é desaconselhável para menores, inclusive como aprendiz. Todas essas atividades têm um alto índice de acidentes e apresentam riscos físicos, ergonômicos, mecânicos, biológicos e químicos (SOCHACZEWSKI 2005). Nesse caso, esse trabalho, considerado perigoso, insalubre ou pesado até para adultos, é inteiramente inadequado para crianças e adolescentes e não deveria apresentar nenhum registro de AT em indivíduos em idades tão tenras.

Numericamente inferiores 129 casos entre 1997 e 1999, os registros de AT observados nessa pesquisa para a cultura de frutas cítricas foram proporcionalmente superiores, perfazendo $6,2 \%$ do total dos registros de acidentes notificados, sendo que destes $1,55 \%$ eram menores de 14 anos. Estudo realizado entre os colhedores de 
laranja, no interior paulista, mostra que alguns trabalhadores com filhos menores os levam para auxiliar na hora da colheita, aumentando assim, a quantidade colhida e sua remuneração (BAPTISTELLA 1998), expondo essas crianças a muitas adversidades.

A Abecitrus assinou em 28 de maio de 1996, um compromisso público para a erradicação do trabalho infantil na cadeia produtiva do suco concentrado de laranja, oficializado pelos governos federal e estadual e com o aval e reconhecimento de organizações internacionais, comprometendo-se em não utilizar em suas fazendas a força de trabalho infantil (ABECITRUS 1996).

Segundo BAPTISTELLA (1998), as indústrias do suco paulista empregam trabalhadores com idade mínima de 14 anos e com registro em carteira, o que nessa idade, segundo a Legislação Brasileira ${ }^{11}$, o ingresso desses adolescentes só pode ocorrer em atividades remuneradas como aprendiz, o que justifica a presença de registros de AT com adolescentes maiores de 14 anos.

Entretanto, no setor citrícola, $92 \%$ das propriedades são de pequeno porte e algumas destas propriedades, por tradição ou questões econômicas, utilizam mão-deobra de crianças e adolescentes da própria família (ABECITRUS 1996).

Faz-se necessário salientar, que essa informação como outras advindas de registro administrativo, podem resultar de erros de preenchimento, entretanto estudos e estatísticas nacionais e internacionais comprovam a existência de menores trabalhando nas atividades agrícolas, apesar de proibidos por lei.

De qualquer forma, um assunto tão sério carece da necessidade de ser averiguado através de estudos específicos.

\footnotetext{
${ }^{11}$ Em 1998, a Emenda Constitucional 20 altera artigo 227 da Constituição, elevando a idade mínima para o trabalho de 14 para 16 anos e determinando que, a partir dos 14 anos, o adolescente possa ingressar em uma atividade remunerada como aprendiz.
} 
5.5.8 Distribuição da ocupação do trabalhador nas culturas sucroalcooleiras e cítrica

O processo produtivo das culturas da cana-de-açúcar como da laranja possuem diferentes etapas, entre elas se encontram: o preparo do solo, o plantio, a adubação, a conservação do solo, o corte/colheita, o carregamento e o transporte para as unidades de beneficiamento (FUNDACENTRO 1998). Nessas etapas, observa-se inúmeros profissionais envolvidos, registrados como trabalhadores rurais, ruricolas, cortadores/colhedores, lavradores, tratoristas, motoristas etc., sendo que alguns deles realizam várias dessas etapas.

Essa variável descrita como se encontrava preenchida na CAT, sofre o problema de trabalhadores exercendo as mesmas funções estarem registrados, inclusive na carteira de trabalho, de forma diferenciada, o que dificulta a análise dessa variável (CARMO 1996).

Aparentemente, nesta pesquisa, observa-se que os trabalhadores exercendo atividades manuais apresentaram grande número de AT, tanto na cultura sucroalcooleira como na cítrica. Os trabalhadores que exerciam atividades mais específicas, descritas na CAT, como: aplicador de defensivos agrícolas, motoristas, operadores de máquinas agrícolas e tratoristas registraram um menor número de AT, informações similares foram observadas no trabalho da FUNDACENTRO (1998).

Vale a pena chamar a atenção, que mesmo no corte mecanizado da cana-deaçúcar, é imprescindível a presença, do cortador-de-cana e do bituqueiro. Neste, segundo SCOPINHO (1999), citando ALVES (1992), o cortador-de-cana-bituqueiro é responsável pelo acabamento do talhão, sua função é cortar, amontoar e recolher a cana que a máquina não conseguiu realizar. Dessa forma, o trabalho manual é observado em todas as etapas do processo. 
5.5.9 Distribuição dos registros de AT segundo as partes do corpo atingidas

Com referência à parte do corpo atingida, outra variável selecionada, observase que para as doenças do trabalho, o tronco e os membros superiores (braços e mãos) foram os mais afetados. Conseqüência de postura inadequada e esforços contínuos e repetitivos (REVISTA PROTEÇÃO 2003, p.45) que grande parte das atividades rurais exige, assim como carregamento de peso excessivo.

Em um estudo de prevalência de acidentes no exercício das atividades entre os agricultores das fazendas do Alabama e do Mississipi foi constatado que os dedos, mãos e as costas eram as partes do corpo mais lesadas (LYMAN et al 1999).

No caso dos acidentes-tipo as partes do corpo mais atingidas foram os membros inferiores, onde os pés e as pernas foram os mais afetados com ferimentos causados por instrumentos de corte (REVISTA PROTEÇÃO 2003). Os membros superiores também representaram importante participação.

Outra parte do corpo que se mostrou bastante vulnerável no acidente-tipo, tanto para a cultura sucroalcooleira como para a de frutas cítricas, foram os olhos do trabalhador. Os olhos são, segundo estudos realizados pela FUNDACENTRO (1998) alvos fáceis da ponta da cana e das folhas existentes no canavial que pode chegar a cortá-los (REVISTA PROTEÇÃO 2003); assim como da fuligem decorrente da queimada do canavial; na laranja, os galhos da árvore são uma grande ameaça.

A postura corporal do cortador de cana é de constante flexão de tronco, e intensa utilização da musculatura dos braços e punho. A contração abrupta e desordenada das grandes massas musculares podem originar forças de grandes intensidades que causam lesões nas estruturas do corpo, levando ao aparecimento de dores e conseqüentemente inflamações que levam o trabalhador a adoecer (PROCANA 2003). 
No caso da laranja, as sacolas tradicionalmente usadas na colheita que são levadas lateralmente ao corpo do trabalhador são muito pesadas, demando um esforço muito grande.

$O$ intenso ritmo de trabalho que exige grande esforço fisico observado nessas atividades profissionais pode provocar sérios problemas de saúde (WÜNSCH FILHO 2003), além de provocar acidentes de modo direto (RODRIGUES e GRAZIANO DA SILVA 1985) que é determinado muito pela forma de remuneração por produção. Quando a remuneração do trabalho é feita por produção, a tendência é de aumento do rendimento, o que faz com que o trabalhador, mesmo estando cansado, continue trabalhando intensamente com o intuito de atingir sua meta (GOMES et al 200; REVISTA PROTEÇÃO 2003), tornando a atividade mais penosa (FERREIRA 1998).

\subsection{Descrição dos ATs e das doenças do trabalho}

Entre os campos selecionados da CAT transcritos ou codificados no levantamento da Fundação Seade/Fundacentro, encontra-se a Descrição do AT e das Doenças do Trabalho. Este junto com os campos: agente causador, hora do acidente e após quantas horas de trabalho ocorreu o acidente são essenciais para explicar o acidente propriamente dito e o surgimento da lesão, e constituem informações fundamentais para a realização de intervenções de prevenção nos programas de saúde pública do trabalhador.

Espaço onde é relatado o modo de como ocorreu o AT, ou seja, a maneira de como o trabalhador foi lesado, sua codificação constitui-se de uma tarefa dificil de ser realizada, que se agrava em razão do preenchimento inadequado da CAT. Sabese, inclusive, que o preenchimento inadequado é uma das limitą̧ões desse registro administrativo.

A dificuldade de codificar tal campo foi observada também pelo Sistema de Informações para Acidentes e Doenças do Trabalho - SISCAT, desenvolvido pelo 
Programa de Saúde do Trabalhador da Zona Norte - PST, da Secretaria do Estado de São Paulo e depois pelo Centro de Referência em Saúde do Trabalhador CEREST/SP.

Com o interesse de identificar os tipos de acidentes mais comuns na zona norte de São Paulo e os ambientes de trabalho nos quais esses acidentes ocorriam com mais freqüência, o SISCAT foi implantado em 1988, com o objetivo de codificar e digitar as informações existentes na CAT registradas na Previdência Social da região norte de São Paulo (CARMO 1996).

A exemplo da pesquisa da Fundação Seade/Fundacentro, a equipe de codificação do SISCAT, constituída por pessoal de nível médio, seguia metodologia própria na codificação dos campos selecionados (CARMO 1996). Com relação a este campo o SISCAT, elaborou previamente uma lista com códigos especificos, que posteriormente foi abandonada porque o uso da causa externa com base no CID é internacional e facilita comparações com outros trabalhos, além dos acidentes de trabalho serem ocorrências relevantes dentre as causas externas atendidas em serviços de saúde (CONCEIÇÃO et al 2003).

A codificação da Fundação Seade/Fundacentro foi obtida através da leitura e da compreensão dos codificadores, que também recorriam a variável agente causador, para qualquer esclarecimento (FUNDAÇÃO SEADE/FUNDACENTRO 2001).

Inicialmente foi utilizada a Classificação Internacional de Doenças - CID10, da Organização Mundial da Saúde - OMS, referente ao capítulo XX de Causas Externas de Morbidade e de Mortalidade (V01-Y98). Entretanto, em razão da gama de informações advindas da CAT, essa listagem foi ampliada por essa instituição através da criação de outros códigos. 
Esse detalhamento que tinha como objetivo captar todas as possibilidades transcritas dos registros oficiais acabou por misturar eventos que correspondem a "causas externas" (como exemplos: acidentes com objetos cortantes, ataque de animais, atropelamento, esmagamento etc) com outros que se referem à natureza da lesão ou lesões (classe de lesão física sofrida), como queimaduras, traumatismos ou lesões etc.

Na codificação da Fundação Seade/Fundacentro, a presença das categorias Causa Externa e Natureza da Lesão na mesma listagem acabou por dificultar sua análise (Anexo 3). Havendo necessidade de se repensar a metodologia de codificação deste campo, de forma a torná-lo mais objetivo e menos suscetível a interpretação subjetivas diferentes, sendo o mais lógico a utilização exclusiva da listagem da CID com codificadores iniciados nesse conhecimento, como já ficou indicado pelo histórico do SISCAT.

Para esta dissertação, o ideal seria a realização de tal, ou seja, refazer nova codificação respeitando a Classificação Internacional de Doenças - CID10, entretanto por falta de conhecimento adequado de CID e de tempo, não foi possível fazê-lo, o que impossibilitou a análise desse tópico tão importante à saúde do trabalhador.

\subsection{Indicadores de Índice de Freqüência, Índice de Gravidade e Índice de Custo}

Os indicadores Índice de Freqüência, Índice de Gravidade e Índice de Custo, que visam medir os acidentes que geraram beneficios, dias perdidos e gastos, divulgados pela Previdência Social, não foram calculados em razão de não estarem disponíveis as informações referentes ao número de Homens-Hora-trabalhadas (HHT) - onde HHT representa o número total de homens-horas-trabalhadas, sendo calculado pelo somatório das horas de trabalho de cada pessoa exposta ao risco de se 
acidentar, aproximado pelo produto entre o número de trabalhadores, jornada de trabalho diária e número de dias trabalhados no período em estudo, sendo o número de trabalhadores obtido a partir do número médio de vínculos no ano, assim como também a Contribuição Total das Empresas, denominador do índice de Custos (MPS 2002).

\subsection{Estimativa da incidência acumulada, mortalidade e letalidade}

Um dos objetivos deste estudo é analisar a distribuição geográfica dos registros de AT ocorridos entre 1997 e 1999 em áreas rurais paulistas, assim como das culturas sucroalcooleiras e cítricas, a partir das estimativas das taxas de incidência acumulada, mortalidade e letalidade. Essas foram calculadas considerando todos os registros de AT com trabalhadores residentes em municípios do Estado de São Paulo para cada sexo.

Foi adotada como denominador a população em idade ativa, aqui considerada como aquelas compreendida entre 10 e 69 anos, por sexo, residente em algum município do Estado de São Paulo, ocupada em atividade agropecuária, florestais, caça e pesca (áreas rurais) ou atividades referentes ao cultivo da cana-de-açúcar (cultura sucroalcooleira) e das frutas cítricas (cultura das frutas cítricas), contribuintes de Instituto de Previdência Oficial. Obtidas pelo Censo Demográfico de 2000 - IBGE, foram estimadas para a metade dos anos 1997, 1998 e 1999. Esta população foi selecionada por apresentar informações para todas as áreas geográficas do Estado de São Paulo. Não se utilizou a população proveniente da PNAD, porque esta pesquisa é amostral e não apresenta desagregação municipal.

O cálculo das taxas de incidência acumulada, mortalidade e letalidade para as áreas elaboradas seguiram o critério de agrupamento de municípios com população inferior a 10 mil trabalhadores com no mínimo 20 registros de AT (Capítulo Material e Método). 
Os resultados obtidos, com base nesse critério, levaram à elaboração de 33 áreas para os registros de AT ocorridos no meio rural, seis para os registros de AT da cultura sucroalcooleira e quatro para a cultura cítrica.

Para os ATs das áreas rurais paulistas obteve-se para o total do Estado de São Paulo uma taxa de incidência acumulada que variou praticamente de 43 a 56 registros de AT por mil trabalhadores residentes no Estado, ocupados em atividades primárias e contribuintes de Previdência Oficial.

Por sexo, as taxas mais altas foram encontradas entre os homens que variaram de 45 a 58 registros de AT por mil trabalhadores desse sexo. Para o sexo feminino, a variação foi de 31 a praticamente 43 registros de AT por mil mulheres trabalhadoras entre 1997 e 1999.

Da mesma forma, observam-se taxas de mortalidade e letalidade mais elevadas para o sexo masculino para o total do Estado de São Paulo. Com valores bem superiores, a cultura sucroalcooleira registrou taxas de incidência acumulada acima de 100 registros de AT por mil trabalhadores. Situação extensiva ao sexo masculino, as mulheres concentraram taxas de incidência acumulada que variaram de 68 a 86 registros de AT por mil trabalhadoras ocupadas neste cultivo.Quanto às taxas de mortalidade e letalidade não foi registrado nenhum óbito feminino por AT para esta cultura em 1997 e 1998.

A maior concentração das taxas de incidência de mortalidade e de letalidade de AT para o sexo masculino observadas nesta pesquisa é coerente com outros estudos que indicam que os homens tendem a sofrer, em geral, mais AT, inclusive fatais (WALDVOGEL 2002, LUCCA e MENDES 1993; PIANOSI 1995). Para BIDDLE e BLANCIFORTI (1999), historicamente o número e as taxas de acidentes e de doenças do trabalho têm sido menores para as mulheres do que para os homens. 
A cultura de frutas cítricas notificou as taxas mais inferiores de incidência acumulada para o Estado de São Paulo, entretanto, foi a que mais registrou tendência de crescimento dessas taxas.

Com relação ao sexo, observa-se mais uma vez que esse tipo de cultura apresenta um padrão distinto dos registros de AT da cultura sucroalcooleiro e das áreas nurais, enquanto nestas para os homens as taxas eram mais elevadas, o sexo feminino registrou taxas próximas à masculina ou como em 1999, superior. Entretanto, em nenhum dos três anos considerados o sexo feminino apresentou alguma morte por AT nessa cultura.

Tendo conhecimento que a distribuição geográfica dos registros de AT podem contribuir como ponto de partida para que "seja priorizado o desenho de medidas de correção das condições de trabalho que se associam a um alto risco de acidentes" (SAMPAIO et al 1998), calculou-se as taxas de incidência acumulada, mortalidade e letalidade por áreas constituídas pelos municípios do Estado de São Paulo.

A área elaborada para os registros de AT do meio rural, que entre 1997 e 1998 apresentou as maiores taxas, foram as regiões noroeste e nordeste do Estado, estas regiões concentram a agricultura de maior valor comercial do Estado, em particular as atividades dos complexos agroindústrias de cana-de-açúcar e da laranja (BALSADI et al 2001).

A localização e a diversidade agrícola do interior paulista está ligada à tradição da produção das lavouras, às condições do solo, clima e a instalação das agroprocessadoras (OLIVEIRA e TARTAGLIA 1993). Ou seja, nas palavras de OLIVEIRA e TARTAGLIA (1993, p.65), “(....) existe uma forte integração entre as indústrias, a agricultura e as processadoras de matérias-primas e produtos agrícolas, que tornam determinado grupo de municípios depositários de complexos e ricos processos de produção de riqueza capitalista". Estes municipios desenvolveram e são beneficiados por alguns dos principais eixos rodoviários do Estado, como as Vias 
Anhanguera, Washington Luís, Marechal Rondon e Presidente Castelo Branco que possibilitam o desenvolvimento econômico e o fácil escoamento da produção.

Em torno desses eixos, destacam-se alguns municípios que tradicionalmente concentram as culturas da cana-de-açúcar e da laranja, estes municípios atingem áreas extensas que incluem Piracicaba, Limeira, Araraquara, Bebedouro, Jaú, Ribeirão Preto, entre outros (OLIVEIRA e TARTAGLIA 1993).

Dessa forma, vale ressaltar que a maior incidência de registros de AT em algumas áreas pode não significar necessariamente maior gravidade, mas podem ser decorrentes da presença de grandes agroindústrias e por isso nessas áreas o trabalho formal (com registro em carteira) é mais instituído, em relação às áreas com menor presença de trabalho formal.

É preciso lembrar, que o trabalho informal, familiar e precário se concentra nas pequenas empresas (RIBEIRO 2000) localizadas, em geral, em áreas mais periféricas das grandes eixos rodoviários. Essa questão, em parte, ajuda a justificar o fato de alguns municípios não apresentarem registros de AT e/ou trabalhadores agrícolas não assegurados.

Considerando-se que no setor citrícola, $92 \%$ das propriedades são de pequeno porte (ABECITRUS 1996), pode-se induzir que o número de acidentes nesse setor é muito maior do que o captado por esta pesquisa.

Como se sabe, as áreas de cultivo das usinas atingem grandes extensões de terra (FUNDACENTRO 1998) e não respeitam os limites municipais, o que obriga os trabalhadores a se deslocarem constantemente de um município para outro. Dessa forma, muitos municípios próximos servem de residência de trabalhadores ocupados nessa atividade. 
Espalhada por praticamente todo o Estado de São Paulo, com exceção de algumas regiões mais litorâneas do Estado, a cana-de-açúcar não se encontra presente nos municípios do litoral sul paulista nem no Vale do Paraíba, entretanto registra em alguns desses municípios trabalhadores ocupados nesse tipo de cultivo segundo dados do IBGE. Estes trabalhadores, provavelmente, se movimentam diariamente para trabalhar nos municípios mais centrais do Estado, próximos a regiões de Sorocaba e Campinas, que abriga importantes usinas sucroalcooleira, constituindo a área elaborada de cultura sucroalcooleira número um, que em 1997 e 1998 registraram as mais elevadas taxas de incidência acumulada.

A alta taxa de incidência acumulada da cultura na área 6, principalmente em 1999 é no mínimo curiosa. Situada a oeste do Estado, essa área além de ser a principal exportadora nacional de carne bovina, também possui importante presença de usinas de cana-de-açúcar como a Usina de Alta Floresta (FUNDAÇÃo SEADE 2005), o que pode explicar essa alta incidência.

Com relação às taxas de mortalidade e de letalidade todas as áreas elaboradas para essa cultura apresentaram baixos índices.

Os dados sobre AT registrados junto a Previdência Social de 2002, segundo a Classificação Nacional de Atividade Econômica - CNAE, corroboram com esses resultados. Nela o cultivo da cana-de-açúcar mostra a mais elevada taxa de incidência de AT entre os tipos de culturas existentes no Estado de São Paulo, enquanto as taxas de mortalidade e letalidade não se encontram entre as mais expressivas (PREVIDÊNCIA SOCIAL 2002).

No que concerne à cultura das frutas cítricas, os principais municípios do cultivo encontram-se a nordeste, centro e noroeste do Estado, entre eles encontram as regiões próximas aos municípios de Bebedouro, importante produtor de frutas cítricas; São José do Rio Preto, Ribeirão Preto (em menor escala), Campinas, São Carlos, Araraquara, que possui a maior empresa de sucos cítricos do País; (FUNDAÇÃO SEADE 2005; BAPTISTELLA 1998; ROMEIRO 2002) e que 
apresentam agroindústrias com presença de força de trabalho formal. Observa-se que próximas a estes últimos municípios que se concentram as áreas elaboradas com as maiores taxas de incidência acumulada, as áreas 1 e 2, em todos os anos considerados.

Foram também estas áreas elaboradas, as únicas a registrarem taxas de mortalidade e letalidade em 1997 e 1998 para essa cultura.

Vale a pena salientar que áreas com baixas incidências e altas taxas de mortalidade e, sobretudo letalidade, podem indicar um sub-registro de acidentes leves. No Brasil, é comum o sub-registro dos ATs de menor gravidade, fato este já apontado por diversos pesquisadores como: BINDER e CORDEIRO 2003; WÜNSCH FILHO 1995; CARMO et al 1995; ALVES e LUCHESI 1992; RIBEIRO e LACAZ 1984. 


\section{CONCLUSÕES}

Apesar de apresentar restrições, por compreender, somente os trabalhadores inseridos no mercado formal da economia, as CAT's constituem-se, importante material de análise, fornecendo relevantes subsídios, para o entendimento da questão acidentária

A dificuldade no levantamento de dados, referentes aos acidentes e doenças do trabalho rural, principalmente no que concerne aos dados desagregados, não é um fato exclusivamente brasileiro. Pois, também foi observado em outros países, como aponta HAYDEN (1995), que também identificou dificuldades símiles na falta de informações sistemáticas sobre os acidentes e doenças do trabalho, na agricultura americana.

O estudo dos ATs nas áreas rurais e nas culturas sucroalcooleiras e de frutas cítricas, realizado com base nos registros administrativos, ou seja, nas CAT's, estão longe de representar a totalidade das ocorrências destes acidentes. Entretanto, considera-se que para delinear um panorama dos AT no País, as CAT's constituem importante fonte de informação. Não só para a elaboração de estatísticas oficiais, mas também, para alicerçar estudos epidemiológicos.

Com base no tratamento de dados dos registros de AT obtidos por meio das informações transcritas das CAT's, realizadas em todas as agências da Previdência Social do Estado de São Paulo, entre 1997 e 1999, é possivel inferir que:

- Os ATs são, indubitavelmente, um grave problema de saúde pública nas áreas rurais do Estado de São Paulo, assim como, nas culturas sucroalcooleiras e cítricas.

- Apesar de em sua maioria, os registros de AT, nas áreas rurais e nas culturas sucroalcooleiras e das frutas cítricas, serem de acidentes-tipo, verificou-se 
aumento nos acidentes de trajeto, registrados entre 1997 e 1999, nas culturas sucroalcooleiras e nas de frutas cítricas. Nesse sentido, talvez vale a pena arriscar, que o que possa estar ocorrendo seja uma melhor notificação dos ATs em área rural com relação a este tipo de acidente, uma vez, que as más condições de transporte dos trabalhadores e as péssimas condições das estradas, já muita apontadas por diversos pesquisadores (RODRIGUES e GRAZIANO DA SILVA 1986; ALESSI e NAVARRO 1997; NEVES 1994) não são recentes.

- A grande maioria dos acidentes registrados na Previdência Social, ocorridos em áreas rurais, assim como de trabalhadores inseridos nas culturas sucroalcooleiras ou de frutas cítricas tiveram, como conseqüência, a incapacidade temporária, incluindo os eventos com afastamentos inferiores e superiores a 15 dias.

- Os registros dos ATs na cultura das frutas cítricas distinguem-se tanto com relação ao sexo, como em relação à distribuição qüinqüenal da idade. Essa diferenciação deve-se à distinção existente entre a força de trabalho requerida pelas empregadoras para a realização destas duas culturas, como atividade conhecidamente extenuante, a cultura sucroalcooleira exige uma força de trabalho mais jovem, o que faz com que na hora da contratação as usinas prefiram trabalhadores jovens e do sexo masculino.

- Dos ATs registrados entre menores de 18 anos observou-se que 1,02\% envolviam trabalhadores com idades inferiores a 14 anos, para os registros de acidentes nas áreas rurais; $1,34 \%$ para a cultura sucroalcooleira e 1,55\% para a cultura de frutas cítricas. Apesar de proibido por lei, inclusive como aprendizes, os menores que ainda não atingiram o limite inferior legal de idade, para o trabalho, encontram-se expostos ao risco de sofrer AT nas áreas rurais do Estado de São Paulo. 
- No que se refere à parte do corpo atingida, observa-se que, para as doenças do trabalho, o tronco e os membros superiores (braços e mãos) são as mais afetadas, enquanto para os acidentes-tipo, as partes do corpo mais atingidas são: os membros inferiores, os pés e as pernas, os mais afetados. Outra parte do corpo, bastante vulnerável no acidente-tipo, tanto para a cultura sucroalcooleira, como para a cultura de frutas cítricas, são os olhos do trabalhador.

Observa-se para o total do Estado de São Paulo, uma queda nas taxas de incidência acumulada, entre 1997 e 1999 por mil trabalhadores residentes, ocupados em atividades primárias e contribuintes da Previdência Oficial, queda que se repetiu para ambos os sexos. Também verificou-se uma tendência de declínio nas taxas de mortalidade e letalidade, sendo que o sexo masculino registrou as taxas mais elevadas.

Em relação à cultura sucroalcooleira, registraram-se taxas de incidência acumulada acima de 100 registros de AT, por mil trabalhadores. As mais elevadas das dimensões estudadas e com leve tendência de aumento, no período referido. $O$ sexo masculino apresentou taxas elevadas e crescentes e, o feminino, taxas inferiores e decrescentes. Mais uma vez, vale a pena salientar o quanto é extenuante fisica e emocionalmente esta atividade profissional.

As taxas de mortalidade e letalidade registradas, por mil trabalhadores, fixaram-se com baixos índices, entre 1997 e 1999. Não havendo nenhum registro de óbito, por AT, para o sexo feminino.

Com taxas que variaram entre 12 e 20 registros de AT, por mil trabalhadores, a cultura de frutas cítricas registrou as mais baixas taxas de incidência acumulada, para o total do Estado de São Paulo, entre 1997 e 1999, enquanto as taxas de letalidade, de 1997 e 1998, foram as mais elevadas entre as dimensões pesquisadas, principalmente, em relação ao sexo masculino. Essa letalidade deve ser vista com precaução, uma vez que pode ser resultado da subnotificação de acidentes leves. 
O conhecimento e acesso dos registros de AT para áreas geográficas menores, como os municípios, assim como, a identificação das populações, supostamente expostas ao risco de tais acidentes, permitiram estimar as taxas específicas de incidência acumulada e de mortalidade para esta população, representando indicadores de comparações regionais, aprofundado a análise sobre os acidentes do trabalho. Indubitavelmente, o estudo regionalizado pode ajudar a aprofundar a análise sobre o AT, delineando o perfil epidemiológico das regiões analisadas.

Das 33 as áreas elaboradas, para os registros de AT, do meio rural, destacaram-se os municípios que apresentam ou se localizam próximos aos grandes centros de desenvolvimento agroindustrial, principalmente, da cana-de-açúcar e do suco de laranja, regiões situadas mais a noroeste, nordeste e centro-oeste do Estado de São Paulo. Estas áreas solicitam um grande número de trabalhadores.

Nas seis áreas elaboradas para a cultura sucroalcooleira, verifica-se que, praticamente todas registraram altas taxas de incidência acumulada, uma vez que a cana-de-açúcar se encontra espalhada por quase todo o Estado de São Paulo. As maiores incidências acumuladas foram em torno das regiões que concentram grandes centros agroindustriais e por municípios limítrofes a estes, como: Ribeirão Preto, Bauru, São José do Rio Preto, Araçatuba, São Carlos, Araraquara, Marília, Franca, assim como Presidente Prudente, que apesar de ser a principal exportadora nacional de carne bovina, possui importante usinas de cana-de-açúcar como a Usina de Alta Floresta.

A agroindústria sucroalcooleira demanda um grande número de trabalhadores no processo de plantio e colheita, sendo responsável pela ocupação de mão-de-obra no campo.

Apesar de concentrar a menor taxa de incidência acumulada nos anos pesquisados, a área elaborada para a cultura sucroalcooleira 5 apresentou a maior taxa de mortalidade e letalidade para o total da população e para o sexo masculino 
em 1997 e 1999. Isso pode ser o indício que esta pode ser uma área com importante subnotificação de acidentes leves.

A agroindústria do suco de laranja, junto com a da cana-de-açúcar é uma das que mais demanda mão-de-obra do interior paulista. Entre as quatro áreas elaboradas, da cultura das frutas cítricas, destacaram-se, com as maiores taxas de incidência acumulada, os municípios das áreas elaboradas 1 e 2, que concentram municípios próximos aos principais municípios desse cultivo, entre eles encontram as regiões de Campinas, São Carlos e Araraquara, que possui a maior empresa de sucos cítricos do País.

Nas áreas elaboradas 3 e 4 encontram-se também importantes produtores de frutas cítricas, como os municípios de São José do Rio Preto, Ribeirão Preto e Bebedouro. Nesta cultura somente em 1997 e 1998 foram registradas taxas de mortalidade e letalidade para o sexo masculino nas áreas elaboradas 2 e 1, respectivamente.

À guisa destes resultados, a distribuição geográfica regional dos Ats, no Estado de São Paulo, é diretamente proporcional à densidade populacional rural è à concentração dos grandes centros agroindustriais sucroalcooleiros e do suco de laranja, áreas onde o trabalho formal esta mais instituído. 


\section{CONSIDERAÇÕES FINAIS}

Esse trabalho resulta de um projeto realizado pela Fundação Jorge Duprat Figueiredo de Segurança do Trabalho - Fundacentro e da Fundação Sistema Estadual de Análise de Dados - Seade que entre 2000 e 2001 percorreu todas as agências e postos da Previdência Social do Estado de São Paulo levantando dados estatísticos referentes aos registros de AT de 1997 a 1999, do qual tive a oportunidade de participar como supervisora de uma das equipes de campo.

Nesta dissertação pretendia, por meio desses registros administrativos de AT, criar informações úteis para o estudo da relação saúde/trabalho dos trabalhadores rurais segurados da Previdência Social e residentes no interior paulista, traçando um panorama de seu cotidiano acidentário nesse periodo.

Não objetivava, entretanto, criar políticas de prevenção na área de saúde do trabalhador, apesar de calcular medidas de risco, mas chamar atenção para essa classe laboral que se encontram entre as categorias profissionais mais sujeitas a sofrer sérios problemas de saúde no local de trabalho.

A pertinência das culturas sucroalcooleira e das frutas cítricas se traduz na importância para o setor primário da economia dessas duas culturas, que junto com o café, se configuram como as principais lavouras do Brasil e do Estado de São Paulo.

Uma contribuição acredita-se dessa dissertação, foi demonstrar que é possível construir indicadores, como os de incidência, mortalidade e letalidade propostos por áreas, a partir de informações obtidas do Censo Demográfico do IBGE, que provou ser uma alternativa viável, econômica e razoavelmente de fácil acesso e que permite uma análise descritiva mais acurada. 
A análise dos AT por áreas é escassa e pode fornecer o panorama de áreas com alta incidência, indicando medidas de saúde pública. Até mesmo a ausência de registros em determinadas áreas pode ser um indicador útil, identificando a necessidade da realização de pesquisas ou inspeções de agentes da saúde para averiguar a realidade do local.

A abrangência das informações contidas no resultado dessa dissertação demonstra o potencial das informações estatísticas obtidas pelos registros administrativos, indicando sua importância em gerar subsídios à questão acidentária, ainda que apenas referida a trabalhadores com direito ao seguro de AT e sujeita ao sub-registro dos acidentes considerados leves que, muitas vezes, não são notificados.

É pela análise dos registros administrativos, suas deficiências e atributos, que se poderá trabalhar no sentido de aprimorá-los e torná-los fontes estatísticas apuradas.

Não desconsiderando a utilização de outras fontes, como os levantamentos amostrais, de realização onerosa, mas tão essencial no entendimento do AT, o uso da CAT mostrou-se uma alternativa viável.

Outra questão relevante, com base no exposto nesse trabalho é a participação dos registros de AT da cultura sucroalcooleira, que se encontram espalhados por todo o Estado de São Paulo, assim como a migração da incidência desses registros para a região oeste do Estado de São Paulo observada no último ano analisado.

Com relação à saúde do trabalhador muito ainda há a ser feito, apesar das conquistas das últimas décadas que resultaram em melhores condições de vida e saúde. Para isso é necessário olhar esse fenômeno de forma globalizante e multidisciplinar, fazer uma abordagem que extrapole as dimensões legais e médicas, pois os agravos que atingem os trabalhadores devem ser analisados além do corpo 
biológico, buscando no espaço social as explicações de seu desgaste e incorporando nessa discussão o social, o político e o econômico. Dessa forma, toda a sociedade deve participar, afinal é ela que arca com os prejuízos e/ou ganhos relativos à saúde no trabalho. A saúde do trabalhador se dá em todos os setores de sua vida. 


\section{REFERÊNCIAS}

ABECITRUS. O Compromisso de Erradicação do Trabalho Infantil na Citricultura. [online]. 1996. [online]. [acesso em 20 mai 2005]. Disponível:< http://www.abecitrus.com.br/comprom.html

ABECITRUS. A história da laranja. [online]. [acesso em 13 fev 2004]. Disponível:< http://www abecitrus.com.br $>$ ].

Alessi NP, Navarro L. Saúde e trabalho rural: o caso dos trabalhadores da cultura canavieira na região de Ribeirão Preto, São Paulo, Brasil. Cad Saúde Pública 1997; 13(Supl. 2): 111-21.

Almeida IM. Caminhos da análise de acidentes do trabalho Ministério do Trabalho e Emprego. Brasília; 2003.

Almeida IM. Construindo a culpa e evitando a prevenção: caminhos da investigação de acidentes do trabalho em empresas de município de porte médio. Botucatu, São Paulo, 1997; São Paulo; 2001. [Tese de Doutorado - Faculdade de Saúde Pública da USP].

Almeida IM. Desvendando a zona de sombras dos acidentes do trabalho: estudo de acidentes do trabalho graves em Botucatu-SP, no período de 01/01 a 30/06/03; 1995. [Dissertação de Mestrado - Faculdade de Saúde Pública da USP].

Almeida IM, Binder MCP, Tolosa DER. Acidentes do trabalho no município de Botucatu, SP, 1990. Rev. Bras. Saúde Ocup 1993; 21(80): 29-41.

Alvarenga AT. A saúde pública como campo de investigação interdisciplinar e a questão metodológica. Saúde e Sociedade 1994; 3(2): 22-41. 
Alves F. Greve nos canaviais e agricultura modernizada - novos desafios. São Paulo Perspec 1993; 7(3): 133-37.

Alves S, Luchesi G. Acidentes do trabalho e doenças profissionais no Brasil: a precariedade das informações. Inf Epidemiol SUS 1992; 3 :5-20.

Alves Filho JP. International colloquium safety and health protection in agriculture - ISSA. A common challenge for developing and industrial countries (Anexos). Tunisia: Relatório de viagem ao exterior: Ministério do Trabalho e Emprego Fundacentro; 2001.

Andrietta AJ. Desempenho agrícola e desenvolvimento: uma análise regionalizada do Estado de São Paulo. Informações Econômicas 2002; 32(2): 43-55.

Balsadi OV, Borin MR, Silva JG, Belik W. Transformações tecnológicas e a força de trabalho na agricultura brasileira no período 1990-2000. São Paulo Perspec 2002; 49(1): $23-40$.

Balsadi OV, Borin MR, Julio JE. A agropecuária paulista. São Paulo. Fundação Seade, 2001. (Texto elaborado a partir do Caderno Agricultura que a Fundação Seade produziu para a Assembléia Legislativa do Estado, no âmbito do Fórum Século XXI). Mimeo.

Balsadi OV. Mudanças no meio rural e desafios para o desenvolvimento sustentável. São Paulo Perspec 2001; 15(1): 155-165.

Baptistella CSL, Vicente MCM, Veiga JER. Demografia e mercado de trabalho na agricultura paulista nos anos noventa. Informações Econômicas 2000; 30(5).

Baptistella CSL. Colhedores de laranja na indústria paulista. São Paulo; 1998. [Dissertação de Mestrado - Faculdade de Filosofia, Letras e Ciências Humanas da USP]. 
Belik W, Bolliger FP, Silva JG. Agroindústria paulista: heterogeneidade e reestruturação. São Paulo Perspec 1999; 13(1-2): 93-102.

Beraldo PSS et al. Mortalidade por acidentes do trabalho no Brasil - uma análise das declarações de óbitos, 1979 -1988. Informe Epidemiológico do SUS 1993; 2(1): 41 54.

Betancourt O. Salud y seguridad en el trabajo. Quito: OPS/OMS-FUNSAD. 1999; 44-5.

Biddle EA, Blanciforti LA. Impact of a changing U.S. workforce on the occupational injury and illness experience. Am J Ind Med 1999; 36(1): 7-10.

Binder MCP, Cordeiro R. Sub-registro de acidentes do trabalho em localidade do Estado de São Paulo, 1997. Rev. Saúde Pública 2003; 37 (4): 409-416.

Binder MCP, Wludarski SL, Almeida IM. Estudo da evolução dos acidentes do trabalho registrados pela Previdência Social no período de 1995 a 1999, em Botucatu, São Paulo. Cad. Saúde Pública 2001; 17(4): 915-924.

Binder MCP, Almeida IM. Estudo de dois acidentes do trabalho investigados com o método de árvores de causas. Cad Saúde Pública 1997; 13(4): 749-60.

Binder MCP. Acidentes do trabalho e de trajeto na área rural. In: Anais do Seminário: Saúde e trabalho na área rural (Documento Memória); 1993 jul 6-7; São Paulo, (BR). São Paulo: Secretaria de Estado da Saúde Centro de Vigilância Sanitária Divisão de Vigilância Sanitária do Trabalho; 1994: 68-92.

Brasil. Lei 8212 e 8213 de 24/07/1991: Beneficios da Providência Social.. [online]. [acesso em 2003].

Disponível: $<$ http://notes.alerj.rj.gov.br/constfed.nsf/0/af47ff4f967d639603256562006d2 e74?OpenDocument> 
Brito JC. Enfoque de gênero e relação saúde/trabalho no contexto de reestruturação produtiva e precarização do trabalho. Cad Saúde Pública 2000: 16(1): 195-204.

Cardoso F, Ferreira V. Agricultura revigora economia. Cadernos Setoriais [online]. 2002; set;: [acesso em 15 abr 2005] Disponível:< http://www.estadao.com.br/safra/2003/novasafra_001 htm>

Carmo JC. SISCAT- sistema de informações para acidentes e doenças do Trabalho. análise das comunicações de acidentes do trabalho registradas na zona norte do município de São Paulo de 1991 a 1993. São Paulo; 1996. [Dissertação de Mestrado da Faculdade de Saúde Pública da USP].

Checkoway H, Pearce N, Crawford-Brown DJ. Research methods in occupational epidemiology. New York: Oxford University Press; 1989. (Monographs in epidemiology and biostatistics, .13).

Conceição PSA, Nascimento IBO, Oliveira OS, Cerqueira MRM. Acidentes de trabalho atendidos em serviço de emergência. Cad. Saúde Pública. 2003; 19(1): 111-7.

Condé J. A cana-de-açúcar na vida brasileira. Rio de Janeiro, Instituto do Açúcar e do Álcool; 1971/1972. (Coleção Canavieira 7)

Cooper SP, Burau KD, Robison TB, Richardson S, Schnitzer PZ, Fraser JF. Adolescent occupational injuries: Texas, 1990-1996. Am J Ind Med 1999; 35: 43-50.

Corrêa Filho HR. Percepcão de riscos na ocupação precedendo lesões do trabalho: um estudo no município de Campinas, São Paulo, 1992-1993. São Paulo; 1994a. [Tese de Doutorado da Faculdade de Saúde Pública da USP].

Corrêa Filho HR. Outra contribuição da epidemiologia. Rocha LE, Rigotto RM, Buschinelli JTP (org.) Isto é trabalho de gente? Vida, doença e trabalho no Brasil. Petrópolis: Vozes. 1994b: 187-213. 
Cortez SAE. Acidente do trabalho: ainda uma realidade a ser desvendada. Ribeirão Preto/SP - 1996. São Paulo; 2001. [Dissertação de Mestrado - da Faculdade de Medicina de Ribeirão Preto].

Costa AJL, Kale PL. Medidas de freqüência de doenças. Medronho RA (org.) Epidemiologia. São Paulo: Atheneu. 2002: 15-31.

DIESSE - Departamento Intersindical de Estatística e Estudos Sócio-Econômicos. A situação do trabalho no Brasil. São Paulo: Palas Athena. 2001:352p.

Di Santi JB. A realidade do trabalho rural no Estado de São Paulo. In: Seminário: Saúde e trabalho na área rural (Documento Memória); 1993 jul 6-7; São Paulo, (BR). São Paulo: Secretaria de Estado da Saúde Centro de Vigilância Sanitária Divisão de Vigilância Sanitária do Trabalho; 1994: 1-35.

Dwyer T. Uma concepção sociológica dos acidentes do trabalho. Rev Bras Saúde Ocup 1994; 81(22): 15-9.

Dwyer $T$. Life and death at work. Industrial accidents as a case of socially produced error. New York and London: Plenum Press; 1991.

Dwyer T, Raftery AE. Industrial accidents are produced by social relations of work: a sociological theory of industrial accidents. Applied Ergonomics 1991; 22(3): 167-178.

Facchini LA. Uma contribuição da epidemiologia: o modelo da determinação social aplicado à saúde do trabalhador. In: Rocha LE, Rigotto RM, Buschinelli JTP (org.) Isto é trabalho de gente? Vida, doença e trabalho no Brasil. Petrópolis: Vozes. 1994b: 178-186.

Faria NMX Facchini LA, Fassa AG et al Processo de produção nural e saúde na serra gaúcha: um estudo descritivo. Cad Saúde Pública 2000; 16(1): 115-28. 
Faria MAM et al. Saúde e trabalho industrial: acidentes do trabalho em Cubatão. Reunião Anual da Sociedade Brasileira para o Progresso da Ciência (Resumos). São Paulo; 1982: 34-89.

Ferreira LL, Gonzaga MC, Donatelli S, Bussacos MA. Análise coletiva do trabalho dos cortadores de cana da Região de Araraquara, São Paulo. São Paulo; Ministério do Trabalho Fundacentro 1998: 1-57.

Fundação Seade. O Estado dos municípios 2000-2002. Índice Paulista de Responsabilidade Social. São Paulo. 2005:137p.

Fundação Seade. Anuário Estatístico do Estado de São Paulo - Notas Metodológicas 2004. [online]. [acesso em 1 mar 2004]. Disponível:<http:www.seade.gov.br>

Fundação Seade/Fundacentro.: Segurança e saúde em transportes de trabalhadores rurais. Relatório Final do Projeto: São Paulo; 2001.

Fundação Seade. O trabalho das mulheres residentes rurais no Estado de São Paulo. Mulheres e trabalho 2001a. [serial online]. [acesso em 23 out 2003]. Disponível:<http:www.seade.gov.br/mulheres/index_01.htlm>

Cogbill TH, Steenlage ES, Landercasper J, Strutt PJ. Death and disability from agricultural injuries in Wisconsin: a 12-year experience with 739 patients. Trauma 1991; 31: 1632-7.

Gomes JR, Fischer FM, Bedrikow B. Trabalho da criança e do adolescente no corte da cana-de-açúcar. Rev Bras Saúde Ocup 2001; 97/98(26): 9-27.

Graziano da Silva J. Agroindústria e globalização: o caso da laranja do Estado de São Paulo. In: Graziano da Silva J. Globalização, trabalho e meio ambiente: mudanças socioeconômicas em regiōes frutícolas para exportação Recife, Editora universitária, UFPE. 1999: 221-55. 
Graziano da Silva J. Agricultura e emprego. In: Berquó E (org.) Seminário Nacional sobre Emprego e Violência. CNPD - Comissão Nacional de População e Desenvolvimento. Brasília. 1998: 31-36.

Hayden GJ, Gerberich SG, Maldonado G. Fatal farm injuries a five-year study utilizing a unique surveillance approach to investigate the concordance of reporting between two data source. Journal Occup. Environ. Med. 1995; 37(5): 571-7.

Hasse G. A laranja no Brasil. São Paulo: Duprat \& Ioabe Propagandas; 1987.

Hirata $H$, Zarifian $P$. Travail (lê concept de). In: Hirata $H$ et al coordination. Dictionnaire critique du féminisme. $1^{\text {re }}$ édition. Paris: Presses Universitaires de France; 2000: 230-35.

Hirata HS, Salerno MS. L'implantation d'outils statistiques sur l'organisation et les conditions de travail dans les pays dits 'semi-développés' - Le cas du Brésil. In: France, Ministère du Travail, de l'Emploi et de la Formation Professionelle. L'usage des méthodes statistiques dans l'étude du travail; 1995: 117-29. (Serie Cahier Travail et Emploi).

IBGE. Estimativas da População. [online]. [acesso em 1 mar. 2004] Disponível:<http:www.ibge.gov.br>.

IBGE. Censo Demográfico 2000. Documentação dos microdados da amostra: Rio de Janeiro; 2002.

IBGE. Censo Agropecuário: 1995-1996. Rio de Janeiro; 1998: 19. 
JornalCana. Fogo no canavial: dilemas de uma nova legislação [online]. 2002: Disponível: $<\quad$ http://www.jornalcana.com.br/conteudo/noticia.asp?id materia=53> [2004 Abr. 13].

JornalCana. Brasil a doce terra [online]. 2000: [acesso em abr. 2004]. Disponível<http://WWW.jornalcana.com.br $>$

JornalCana. Presidente da Sopral: "As acusações devem ser apuradas". JornalCana. 1993; 1: 4-5.

Kergoat D. Division sexuelle du travail et rapports sociaux de sexe. In: Hirata $\mathrm{H}$ et al coordination. Dictionnaire critique du féminisme. $1^{\text {re }}$ édition. Paris: Presses Universitaires de France; 2000: 35-44.

Lacaz FAC. Saúde dos trabalhadores: cenário e desafios. Cad Saúde Pública 1997; 13(2): 7-19.

Laurell AC, Noriega M. Processo de produção e saúde. Trabalho e Desgaste Operário. Hucitec. 1989: 333p.

Laurenti R, Mello Jorge MHP, Lebrão ML, Gotlieb SLD. Estatísticas de saúde. São Paulo: EPU/EDUSP; 1985.

Laurenti R. A medida das doenças. In Forattini OP. Epidemiologia Geral. São Paulo: Artes Médicas; 1980: 64-85.

Lert $F$. et al $A$ abordagem multidisciplinar na pesquisa de saúde pública. o acidente do trabalho e a segurança ocupacional. Rev Bras Saúde Ocup 1984; 48(12): 36-47.

Liedke ER. Processo de trabalho. In: Cattani AD (org.). Trabalho e Tecnologia Dicionário Crítico. Petrópolis: Vozes. 1997; 181-3. 
Lima RC, Victora CG, Dall'Agnol M, Facchini LA, Fassa A. Associação entre as características individuais e sócio-econômicas e os acidentes do trabalho em Pelotas, Rio Grande do Sul, Brasil. Cad. Saúde Pública 1999; 15(3): 569-580.

Lopes RM. Acidentes do trabalho na mão-de-obra volante empregada na agricultura (Bóias-frias), Botucatu, São Paulo. 1983. [Dissertação de Mestrado -da Faculdade de Medicina da USP].

Lopes RM. Acidentes do Trabalho na Agricultura, Botucatu-SP. Rev Bras Saúde Ocup jul./set.1982; 10(39): 12-7.

Lucca SR, Fávero M. Os acidentes de trabalho no Brasil - algumas implicações de ordem econômica, social e legal. Rev Bras Saúde Ocup 1994; 22(81): 7-14.

Lucca SR, Mendes R. Epidemiologia dos acidentes do trabalho fatais em área metropolitana da região sudeste do Brasil, 1979 a 1989. Rev Saúde Pública 1993; 27(3): 168-76.

Lyman S, McGwin GJr, Enochs R, Roseman JM. History of agricultural injury among farmers in Alabama and Mississippi: prevalence, characteristics, and associated factors. Am J Ind Med. 1999; 35: 499-510.

Machado JMH, Gomez CM. Acidentes de trabalho: concep̧̧̃̃es e dados. Minayo In: MCS (org.) Os muitos Brasis: saúde e população na década de 80 . São Paulo: Hucitec/Abrasco. 1995; 118-142.

Machado JMH, Gomez CM. Acidentes de trabalho: uma expressão da violência social. Cad. Saúde Pública. 1994; 10(1): 74-87.

Mandryk J, Harrison J. Work-related deaths of children and adolescents in Austrália, 1982-1984. Australian Journal of Public Health. 1995; 19(1): 46-9. 
Marx K. Contribuição à Crítica da Economia Política. In FERNANDES F (org.). K. MARX \& F. ENGELS: História. São Paulo: Ática. 1983.

Marx K. O Capital. Crítica da economia política. $O$ processo de produção do capital. Livro 1. São Paulo: Bertrand Brasil - DIFEL. 1987: 579p.

Mello Jorge MHP, Gotlieb SLD, Laurenti R. A saúde no Brasil: análise do período 1996 a 1999. São Paulo: OPASaúde/OMS. 2001:134-37.

Mendes R. Introdução ao estudo dos mecanismos de patogênese do trabalho. In: Mendes R (Org.). Patologia do Trabalho - Atualizada e Amplianda. São Paulo: Atheneu. 2003: 93-186.

Minayo-Gomez, Thedim-Costa. A construção do campo da saúde do trabalhador: percurso e dilemas. Cad. Saúde Pública 1997; 13(2): 21-32.

Ministério da Saúde do Brasil. Aspectos conceituais e estratégias para uma atenção diferenciada à saúde dos trabalhadores nos serviços de saúde. In: Doenças relacionadas ao trabalho - Manual de Procedimentos para os serviços de saúde. Brasília. 2001; 17-26.

MPS - Ministério da Previdência Social. Estatísticas. Indicadores de Acidentes do Trabalho. Indicadores para medir o risco no trabalho. 2002. [online]. [acesso em 12 mar. 2003].Disponível< http://www.mpas.gov.br/12 03 03.htm $>$.

MTB - Ministério do Trabalho - Fundacentro. Segurança e saúde ocupacional rural no Brasil. Informe à OIT. Brasil. 1981.

MTE - Ministério do Trabalho e Emprego. 2004 [online]. [acesso mar. 2004].Disponível<

http://WWW.mte.gov.br/Temas/Segsau/estatisticas/acidentes/conteudo/infbasicas.pdf>. 
Neves H. A realidade do trabalho rural no Estado de São Paulo. In: Seminário: Saúde e trabalho na área rural (Documento Memória); 1993 jul 6-7; São Paulo, (BR). São Paulo: Secretaria de Estado da Saúde Centro de Vigilância Sanitária Divisão de Vigilância Sanitária do Trabalho; 1994:1-35.

NIOSH - National Institute for Occupational Safety and Health. Prevención de muertes, lesiones y enfermedades de trabajadores adolescentes [online]. [acesso em 21 mai 2005]. 2003: Disponível:< http://www.cdc.gov/spanish/niosh/docs/2003$128 \mathrm{sp} . \mathrm{html}>$

NIOSH - National Institute for Occupational Safety and Health. [online]. [acesso em 25 nov 2003].2003: Disponível:< http://www.cdc.gov/niosh/homepage.html $>$.

NIOSH - National Institute for Occupational Safety and Health. Injuries among youth in the United States, 1998. [online - Pdf somente]. [acesso em 15 abr 2005].2001: Disponível: $<$ http://www.cdc.gov/niosh/homepage.html $>$.

Nogueira CM. A feminização no mundo do trabalho: entre a emancipação e a precarização. Actualidade GalizaCIG Confederación intersindical Galega. [online]. [acesso 13 fev. 2004].2003: Disponivel:<http:www.sgalizacig.com/index.html>.

Nogueira DP. Incorporação da saúde ocupacional à rede primária de saúde. Rev Saúde Pública 1984; 18(6): 495-509.

Nogueira EA. A realidade do trabalho rural no Estado de São Paulo. In: Seminário: Saúde e trabalho na área rural (Documento Memória); 1993 jul 6-7; São Paulo, (BR). São Paulo: Secretaria de Estado da Saúde Centro de Vigilância Sanitária Divisão de Vigilância Sanitária do Trabalho; 1994:1-35. 
OIT - Organização Internacional do Trabalho. 2004a [online]. Disponivel na Internet: http://www.oit.org/public/portugue/region/ampro/brasilia/safe day/download/safeday d ados estatisticos.pdf> [2004 mai.12].

OIT Organização Internacional do Trabalho. Boas Práticas de combate ao trabalho infantil - Os 10 anos do IPC no Brasil. 2004 [online]. Disponível: $<$ http $/ /$ www oit .org/public/portugue/region/ampro/brasilia/index.htm\#> [2005 mai.12].

OIT- Organização Internacional do Trabalho. 2003 [online]. Disponível: $<$ http $/ /$ www.ilo.org/ $>$ [2003 nov.].

OIT- Organização Internacional do Trabalho. Introducion a las condiciones y el médio ambiente de trabajo. Publicado bajo la dirección de JM Clerc. Oficina Internacional Del Trabajo. Genebra. 1987.

Oliveira EM, Barreto M. Engendrando gênero na compreensão das lesões por esforços repetitivos. Saúde e Sociedade 1997; 6(1): 77-99.

Oliveira OL, Tartaglia. A dinâmica municipal da agricultura paulista. São Paulo Perspec 1993; 7(3): 60-71.

Paixão F. Lei 8213. In Paixão F. A Previdência Social em perguntas e respostas. $2^{\circ}$. Ed. Porto Alegre. Síntese Ltda. 1991: 167-233.

Pastore J. A dimensão econômica dos acidentes e doenças do trabalho [Palestra realizada na abertura do Fórum de Desenvolvimento, Produtividade e Saúde no Trabalho; 2000 mai 02; São Paulo].

Pena P, Costa DF, Lippel TH, Osório CGM. Proposta de política para a área de segurança e saúde no trabalho, no Ministério do Trabalho e Emprego 2004-2007; In: 
Takahashi MABC, Vilela RAG (org.). A saúde do trabalhador e saúde ambiental: cenário atual, experiências e perspectivas. $2003: 31-43$.

Pereira MG. Epidemiologia - Teoria e prática. Ed. Guanabara Koogan S/A, 1995: 169-397.

Pianosi G. Fatal occupational accidents in Lombardy. Med. Lav. 1995; 86(6): 534-41.

Possas CA. Avaliação da situação atual do sistema de informações sobre doenças e acidentes do trabalho no âmbito da Previdência Social brasileira e propostas para sua reformulação. Rev Bras Saúde Ocup 1987; 15(60): 43-67.

Possas CA. Saúde, medicina e trabalho no Brasil. 1980 [Dissertação de Mestrado Instituto de Filosofia e Ciências Humanas - Universidade Estadual de Campinas].

$\begin{array}{lllll}\text { Previdência Social. [online]. [acesso fev 2004]. } & \text { 2002: }\end{array}$ Disponivel:http//creme dataprev.gov.br/AEATInfoLogo/Inicio.htm.

Procana. Saúde e produtividade no corte de cana. [online]. [acesso 20 mai 2005]. 2003.

Disponivel: $<$ http://www jornalcana com $b r /$ conteudo/noticia asp? area $=$ Tecnologia + Agricola\&secao $=$ Opini $\%$ F5es\&ID_Materia $=7956 .>$.

Revista Ecologia e Desenvolvimento 2000; Ano 10(81), 42-3.

Revista Proteção. O campo pede socorro - faltam as mínimas condições de segurança para a maioria dos trabalhadores rurais. Novo Hamburgo, RS; 1992/93; 20: 16-26.

Revista Proteção. A dura jornada nos canaviais. Novo Hamburgo, RS; 2003; 135: 3548 . 
Ribeiro MCSA. Acidentes do trabalho referidos por trabalhadores moradores na Região Metropolitana de São Paulo em 1994: Um levantamento de base populacional. São Paulo; 2000. [Dissertação de Mestrado - Faculdade de Medicina da USP].

Rodrigues VLGS, Graziano da Silva J. Acidentes de trabalho e modernização da agricultura brasileira. Rev Bras Saúde Ocup 1986; 56(14): 29-39.

Rodrigues VLGS, Graziano da Silva J. Acidentes de trabalho e modernização da agricultura brasileira. Project Agricultural Organization and Performance (PROAGRO). Campinas: 1985. (Relatório de Pesquisa, 8).

Romeiro VMB. Gestão da pequena unidade de produção familiar de citros: uma análise dos fatores influentes no sucesso do empreendimento do ponto de vista do produtor de Bebedouro (SP); 2002. [Dissertação de Mestrado - Departamento de Engenharia de Produção da Escola de Engenharia de São Carlos da USP].

Salim CA, Pereira WA, Mota APFV. Aposentadorias por acidentes de trabalho e doenças profissionais no Estado de Minas Gerais entre 1998 e 2000, segundo a RAIS: uma contribuição à prospecção e analise. In: Salim CA, Carvalho LF (org.). Saúde e segurança no ambiente de trabalho: contextos e vertentes. Belo Horizonte:Segrac Editora e Gráfica Limitada; 2002. p.61-73.

Sampaio RS, Martin MM, Artazcoz LL, MoncadalS. Acidentes de trabalho em Barcelona (Espanha), no período de 1992-1993. Rev. Saúde Pública 1998; 32(4): $345-$ 51.

Santana V, Maia AP, Carvalho C, Luz G. Acidentes de trabalho não fatais: diferenças de gênero e tipo de contrato de trabalho. Cad Saúde Pública 2003; 19(2): 481-93. 
Santos VP, Wünsch Filho V, Carmo JC, Settini MM, Urquiza SD, Henriques. Sistema de vigilância epidemiológica para acidentes do trabalho: experiência na zona norte do municipio de São Paulo (Brasil). Rev. Saúde Publica 1990; 24(4): 286-93.

Schmidt MLG. O mundo do trabalho: o psicodrama como instrumento de diagnóstico da influência da organização do trabalho na saúde dos trabalhadores. 2003. [Tese de Doutorado - da Faculdade de Ciências Médicas da Universidade Estadual de Campinas].

Scopinho RA, Eid F, Vian CEF, Silva PRC. Novas tecnologias e saúde do trabalhador: a mecanização do corte da cana-de-açúcar. Cad. Saúde Pública 1999; 15(1): 147-62.

Silva FS. Acidentes de trabalho com máquinas: estudo a partir do sistema de vigilância do programa de saúde dos trabalhadores da zona norte de São Paulo, em 1991. São Paulo; 1995. [Dissertação de Mestrado - da Faculdade de Saúde Pública].

Silva MAM. A precarização do trabalho feminino na cana. In: Anais do IV Congresso Português de Sociologia; 2000 mai 17-20; Buenos Aires (Argentina). [online]. [acesso em 13 fev. 2004].

Disponivel:<http:www.alat.org/PDFpt/Cortes/GYMT_MoraesSilva.PD>.

Silva ZP, Barreto Junior IF, Sant'Ana MC. Saúde do trabalhador no âmbito municipal. São Paulo Perspec 2003: 17(1): 47-57.

Souza-Lobo E. A classe operária tem dois sexos: trabalho, dominação e resistência. São Paulo: Brasiliense; 1991.

Souza V, Blank VLG, Calvo MCM. Cenários típicos de lesões decorrentes de acidentes de trabalho na indústria madeireira. Rev Saúde Pública 2002; 36(6): 702-8.

Teixeira MLP, Freitas RMV. Acidentes do trabalho rural no interior paulista. São Paulo Perspec 2003; 17(2): 81-90. 
UNICA. A história da Cana-de-açúcar [online]. [acesso em fev 2004].Disponível<http://www.unica com.br/pages/cana brasill asp $>$.

Vieira HR, Mota CCS, Fontan LT, Bernini G, Machado M. Contribuição ao conhecimento dos acidentes do trabalho rural no Estado do Paraná. Rev Bras Saúde Ocup 1983; 44(11):50-66.

Waldvogel BC. Acidentes do trabalho: Os casos fatais. A questão da identificação e da mensuração. São Paulo, 1999. [Tese de Doutorado - Faculdade de Saúde Pública da USP] Coleção de Fontes e Análise. Fundacentro 2002; 1(1) 192p.

Waldvogel BC. Acidentes do Trabalho: vida ativa interrompida. Novos desafios em saúde e segurança no trabalho. PUC Minas, IRT - Instituto de Relações do Trabalho e Fundacentro 2001; 37-57.

Waldvogel BC. Projetar população de áreas pequenas: Qual será o melhor procedimento. Belo Horizonte, 1990. [Tese de Mestrado - Centro de Desenvolvimento e Planejamento Regional - CEDEPLAR da Universidade Federal de Minas Gerais].

Waller JA. Injuries to farmers and families in a dairy state. J Ocup Méd 1992; 34: 41421.

Wünsch Filho V. Perfil epidemiológico dos trabalhadores brasileiros. (Mimeo). 2003.

Wünsch Filho V. Reestruturação produtiva e acidentes de trabalho no Brasil: estrutura e tendências. Cad Saúde Pública 1999; 15(1): 41-51.

Wünsch Filho V. A variações e tendências na mortalidade dos trabalhadores. In Monteiro CA. Velhos e novos males da saúde no Brasil. São Paulo: Hucitec/Nupens/USP. 1995; 289-330. 
Zocchio A. Prática da prevenção de acidentes. ABC da segurança do trabalho. São Paulo: Atlas. 1980.

Zuchi PS. Levantamento dos acidentes de trabalho rural ocorridos e registrados pelo FUNRURAL em 27 municípios mineiros no ano de 1977. In: Anais do XX Congresso Nacional a Prevenção de Acidentes do Trabalho; São Paulo: 1982. 


\section{ANEXO 1 - Modelo do Formulário de Coleta.}

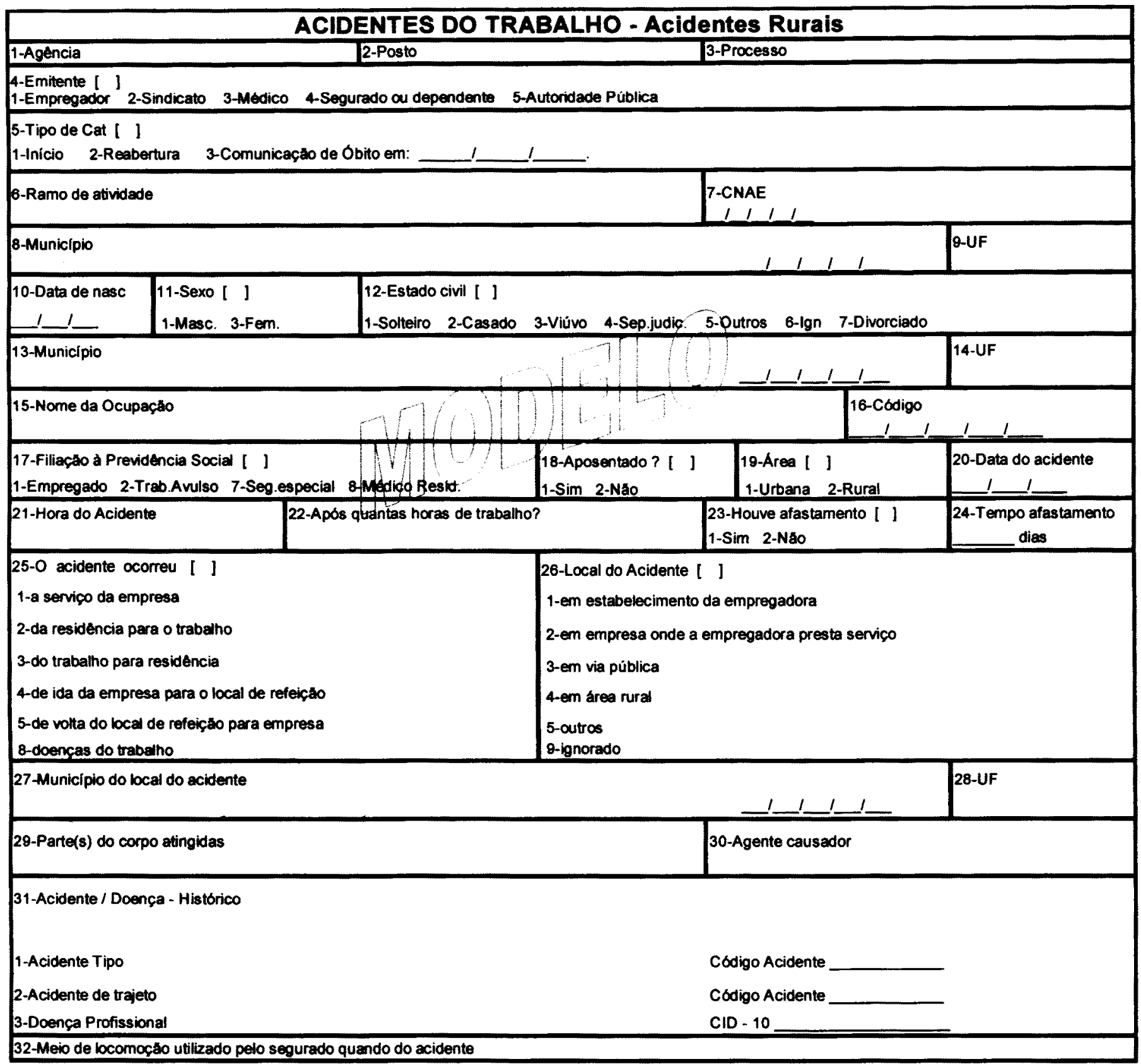


Anexo 2

Agência do INSS do Estado de São Paulo

\section{Agência do INSS}

\begin{tabular}{ll}
100 & Centro \\
120 & Lapa \\
140 & Pinheiros \\
160 & Santo Amaro \\
180 & Tatuapé \\
200 & Vila Mariana \\
220 & Aracatuba/Birigui \\
240 & Araraquara \\
260 & Bauru \\
280 & Campinas \\
300 & Guarulhos \\
320 & Jundiai \\
340 & Marilia \\
360 & Osasco \\
380 & Piracicaba \\
400 & Presidente Prudente \\
420 & Ribeirao Preto \\
440 & Santo André \\
460 & Santos \\
480 & Sao João da Boa Vista \\
500 & São José do Rio Preto \\
520 & Sao Jose dos Campos \\
540 & Sorocaba \\
560 & Taubaté \\
999 & Ignorado \\
\hline
\end{tabular}




\section{Anexo 3 \\ Classificação da Variável - Descrição dos Acidentes do Trabalho e Doenças do Trabalho}

\section{Tipos de acidentes}

3301 Acessórios da cortadeira

2307 Acidente causado por acessórios do veículo de tração animal

2208 Acidentes causados por acessórios da empilhadeira

0708 Acidentes causados por acessórios de automóveis

2107 Acidentes causados por acessórios de lotação

1007 Acidentes causados por acessórios de ônibus ou similares

1107 Acidentes causados por acessórios de tratores

0200 Acidente com animais

0707 Acidente com automóvel sem especificação

0806 Acidente com caminhões ou veículos pesados sem especificação

2907 Acidente com colhedeira sem especificação

2207 Acidente com empilhadeira sem especificação

3107 Acidente com guincho sem especificação

2106 Acidente com lotação sem especificação

0905 Acidente com motocicletas ou similares sem especificação

2607 Acidente com motoniveladora sem especificação

1006 Acidente com ônibus ou similares sem especificação

2507 Acidente com pá/carregadeira sem especificação

2707 Acidente com retroescavadeira sem especificação

2807 Acidente com rolocompressor/compactador sem especificação

1106 Acidente com trator sem especificação

2306 Acidente com veículo de tração animal

2908 Acidentes causados por acessórios da colhedeira

2608 Acidentes causados por acessórios da motoniveladora

2508 Acidentes causados por acessórios da pá/carregadeira

2708 Acidentes causados por acessórios da retroescavadeira

2808 Acidentes causados por acessórios da rolocompressor/compactador

0602 Acidentes causados por acessórios de outros veículos a motor

0505 Acidentes causados por acessórios de transportes aquáticos

0406 Acidentes causados por acessórios do avião

3108 Acidentes causados por acessórios do guincho

3002 Acidentes causados por acessórios do guindaste 


\section{Anexo 3 \\ Classificação da Variável - Descrição dos Acidentes do Trabalho e Doenças do Trabalho}

\section{Tipos de acidentes}

0308 Acidentes causados por acessórios do trem

1713 Acidentes causados por gazes

1716 Acidentes com produtos poluídos

0405 Acidentes de transporte aéreo sem especificação

0500 Acidentes de transporte por água

0307 Acidentes de trem sem especificação

1980 Acidentes causados / provocados por pedestres Acidentes causados devido às más condições de vias públicas

2010 (pedestre)

0807 Acidentes causados por acessórios de caminhões ou veíc. pesados

0907 Acidentes causados por acessórios de motocicletas ou similares

1305 Acidentes causados por arma de fogo sem Intenção de agressão

2020 Acidentes causados por choque com pessoas

1708 Acidentes causados por plantas

1950 Acidentes com objetos cortantes / contundentes

1960 Acidentes com objetos inanimados

0400 Acidentes de transporte aéreo

0504 Acidentes de transportes aquáticos sem especificação

0300 Acidentes de trem

0600 Acidentes de veículos a motor

0601 Acidentes de/com outros veículos a motor

2401 Acidentes decorrentes do uso de calçados/vestuário

1718 Acidentes provocados por exposição ao calor

1714 Acidentes provocados por produtos químicos

1301 Afogamento

0501 Afogamento e submersão de uma embarcação

1200 Agressões

1201 Agressões infligidas por terceiros sem uso de instrumentos

1202 Agressões por arma branca

1203 Agressões por arma de fogo

1204 Agressões por objetos contundentes ou cortantes

1205 Agressões sem especificação

1712 Alergia em geral 


\section{Anexo 3 \\ Classificação da Variável - Descrição dos Acidentes do Trabalho e Doenças do Trabalho}

\section{Tipos de acidentes}

0124 Amputação por acidentes com veículos

1109 Amputação causada por acessório de trator

0810 Amputação causada por acessórios de caminhão

0310 Amputação causada por acessórios do trem

0101 Amputação de membros causada por instrumento de trabalho

0102 Amputação de membros causada por maquinário agrícola

0103 Amputação de membros causada por maquinário industrial

0104 Amputação de membros causada por outros tipos de maquinário

0909 Amputação por acessórios da motocicleta

0710 Amputação por acessórios de automóvel

0122 Amputação por acidentes com veículos

0125 Amputação por ataque animal

0121 Amputação por atropelamento

2509 Amputação por pá carregadeira

0105 Amputação sem especificação

1302 Asfixia / sufocamento

0208 Ataque de animais (mordidas, arranhões, etc...)

0201 Ataque de animais peçonhentos

0207 Ataque de animais sem especificação

0202 Ataque de insetos

0203 Ataque de roedores

2901 Atingido por objeto dentro da colhedeira

2201 Atingido por objeto dentro da empilhadeira

2101 Atingido por objeto dentro da lotação

2601 Atingido por objeto dentro da motoniveladora

2501 Atingido por objeto dentro da pá/carregadeira

2701 Atingido por objeto dentro da retroescavadeira

2801 Atingido por objeto dentro da rolocompressor/compactador

0701 Atingido por objeto dentro de automóvel

0801 Atingido por objeto dentro de caminhões ou veículos pesados

1001 Atingido por objeto dentro de ônibus ou similares

0608 Atingido por objeto dentro de veículo a motor sem especificação

3101 Atingido por objeto dentro do guincho 


\section{Anexo 3 \\ Classificação da Variável - Descrição dos Acidentes do Trabalho e Doenças do Trabalho}

\section{Tipos de acidentes}

0301 Atingido por objeto dentro do trem

1101 Atingido por objeto no trator

2301 Atingido por objeto no veículo

0901 Atingido por objeto usando motocicletas ou similares

1514 Atingido por raio

1400 Atropelamento

1413 Atropelamento por animal

1401 Atropelamento por automóvel

0709 Atropelamento por automóvel quando o motorista é a vítima

1402 Atropelamento por bicicleta

1403 Atropelamento por caminhão

1415 Atropelamento por colhedeira

1411 Atropelamento por empilhadeira

1417 Atropelamento por lotação

0906 Atropelamento por moto ( motoqueiro-vítima)

1404 Atropelamento por motocicleta

1418 Atropelamento por motoniveladora

1405 Atropelamento por ônibus

1406 Atropelamento por outros Meios

1419 Atropelamento por pá-carregadeira

1416 Atropelamento por retro-escavadeira

1407 Atropelamento por trator

0302 Atropelamento por trem

1410 Atropelamento por veículo a motor sem especificação

1408 Atropelamento por veículos de tração animal

1414 Atropelamento rolocompressor/compactador

1409 Atropelamento sem especificação

0700 Automóveis

0800 Caminhões ou veículos pesados

2902 Capotamento da colhedeira

2602 Capotamento da motoniveladora

2502 Capotamento da pá carregadeira 


\section{Anexo 3 \\ Classificação da Variável - Descrição dos Acidentes do Trabalho e Doenças do Trabalho}

\section{Tipos de acidentes}

2702 Capotamento da retroescavadeira

2802 Capotamento da rolocompressor/compactador

0702 Capotamento de automovél

0808 Capotamento de caminhão

2202 Capotamento de empilhadeira

3102 Capotamento de guincho

0908 Capotamento de motocicleta

1108 Capotamento de tratores

0603 Capotamento de veículos a motor sem especificação

1008 Capotamento do ônibus

1303 Cegueira

0204 Choque com um animal

0606 Choque com veículos a motor sem especificação

1515 Choque de causas múltiplas (menos colisão)

0703 Choque de/com automóveis

0802 Choque de/com caminhões ou veículos pesados

2903 Choque de/com colhedeira

2203 Choque de/com empilhadeira

3103 Choque de/com guincho

2102 Choque de/com lotação

0902 Choque de/com motocicletas ou similares

2603 Choque de/com motoniveladora

1002 Choque de/com ônibus ou similares

2503 Choque de/com pá/carregadeira

2703 Choque de/com retroescavadeira

2803 Choque de/com rolocompressor/compactador

1102 Choque de/com tratores

2302 Choque de/com veículo de tração animal

0401 Choque de/entre aviões

0303 Choque de/entre Trens

1500 Choques, explosão e esmagamento.

2900 Colhedeira

0607 Colisão de veículos a motor sem especificação 


\section{Anexo 3 \\ Classificação da Variável - Descrição dos Acidentes do Trabalho e Doenças do Trabalho}

\section{Tipos de acidentes}

0704 Colisão de/com automóveis

0803 Colisão de/com caminhões ou veículos pesados

2904 Colisão de/com colhedeira

2204 Colisão de/com empilhadeira

3104 Colisão de/com guincho

2103 Colisão de/com lotação

0903 Colisão de/com motocicletas ou similares

2604 Colisão de/com motoniveladora

1003 Colisão de/com ônibus ou similares

2504 Colisão de/com pá carregadeira

2704 Colisão de/com retroescavadeira

2804 Colisão de/com rolocompressor/compactador

1103 Colisão de/com tratores

2303 Colisão de/com veículo de tração animal

0402 Colisão de/entre aviões

0304 Colisão de/entre Trens

3300 Cortadeira

1501 Desabamento

0305 Descarrilamento de trem

0209 Doenças causadas por insetos

1940 Doenças fatais

1970 Doenças infecto-contagiosas

1990 Doenças ocupacionais/mal súbito/stress

1502 Eletropressão (choque)

2200 Empilhadeira

1512 Esmagamento

0811 Esmagamento causado por acessórios de caminhão

0106 Esmagamento causado por maquinário agrícola

0107 Esmagamento causado por maquinário industrial

0108 Esmagamento causado por outros instrumentos

0502 Esmagamento entre embarcações que colidem

1110 Esmagamento por acessório do trator

1009 Esmagamento por acessórios de ônibus 


\section{Anexo 3 \\ Classificação da Variável - Descrição dos Acidentes do Trabalho e Doenças do Trabalho}

\section{Tipos de acidentes}

0123 Esmagamento por acidentes com veículos

0809 Esmagamento por caminhão

0127 Esmagamento por ferramenta de trabalho

0126 Esmagamento por objeto inanimado

0309 Esmagamento por trem

0109 Esmagamento sem especificação

3200 Espargideira

1503 Explosão

0403 Explosão de avião

0110 Exposição à radiação ou produtos químicos

0111 Exposição ao ruido

1504 Fulminação (raio)

3100 Guincho

3000 Guindaste

1601 Homicídio ocorrido sem o uso de instrumentos

1602 Homicídio por arma branca

1603 Homicídio por arma de fogo

1607 Homicídio por outros Instrumentos (corda, asfixia)

1605 Homicídio sem especificação

1600 Homicídios

1604 Homicidios por objetos contundentes ou cortantes

2000 Indeterminada

1700 Intoxicações

1701 Intoxicações por alimentos

1702 Intoxicações por contato com plantas

1703 Intoxicações por outros produtos

1704 Intoxicações por produtos químicos agrícolas

1705 Intoxicações por produtos químicos industriais

1706 Intoxicações sem especificação

1505 Inundações

1717 Irritação 


\section{Anexo 3 \\ Classificação da Variável - Descrição dos Acidentes do Trabalho e Doenças do Trabalho}

\section{Tipos de acidentes}

1715 Irritação causada por planta

1711 Irritação provocada por pó/cinza/areia

1606 Latrocínio

1930 Lesões ou doenças causadas pelo uso indevido de remédios

0112 Lesões por esforços repetitivos

2100 Lotação

0900 Motocicletas ou similares

2600 Motoniveladora

1000 Ônibus ou similares

1300 Outras causas de acidentes

0205 Outros acidentes com animais

2500 Pá/carregadeira

2905 Queda da colhedeira rolocompressor/compactador

2205 Queda da empilhadeira (pessoa que caiu da empilhadeira)

3201 Queda da espargideira

2605 Queda da motoniveladora

2505 Queda da pá/carregadeira

1801 Queda de andaime ou similares /torção / escorregar - (altura)

0206 Queda de animais (cavalo)

0404 Queda de avião

1802 Queda de bicicleta / torção / escorregar

1803 Queda de elevador/torção / escorregar

0506 Queda de embarcação/torção/escorregar

1804 Queda de escadas/ degraus/ rampas (escada rolante)/torção/ escor

2104 Queda de lotação (pessoa que caiu) / torção / escorregar

0904 Queda de motocicleta ou similar/torção / escorregar

0605 Queda de outros veículos a motor sem especificação

0306 Queda de trem (pessoa caiu do trem) / torção

1808 Queda de veículo a motor sem especificação

0705 Queda do automóvel (pessoa que caiu do automóvel)

0804 Queda do caminhão ou veículo pesado / torção / escorregar

3105 Queda do guincho (pessoa que caiu) 


\section{Anexo 3 \\ Classificação da Variável - Descrição dos Acidentes do Trabalho e Doenças do Trabalho}

\section{Tipos de acidentes}

3001 Queda do guindaste (pessoa que caiu)

1004 Queda do ônibus (pessoa que caiu) / torção / escorregar

2805 Queda do rolocompressor/compactador

1104 Queda do trator (pessoa que caiu) / torção / escorregar

2304 Queda do veículo (pessoa que caiu)

1805 Queda em via pública ou interior de ambientes / torção / escorregar Queda ou salto de embarcação avariada por colisão, choque ou

0503 chamas.

1806 Queda sem especificação / torção / escorregar

1807 Queda/torção/escorregar/em área rural

1800 Quedas / torção / escorregão

0113 Queimadura causada por instrumentos de trabalho sem especificação

0114 Queimadura causada por maquinário industrial

1510 Queimadura elétrica

1516 Queimadura por raio

0210 Queimadura provocada por insetos

1506 Queimaduras

1507 Queimaduras de sol

1511 Queimaduras por explosão de veiculos

1513 Queimaduras provocadas por produtos químicos

1709 Reações alérgicas a insetos

1707 Reações alérgicas a plantas

1710 Reações alérgicas a produtos químicos

2402 Reações alérgicas decorrentes do uso de calçados/vestuário

2700 Retroescavadeira

2800 Rolocompressor/compactador

1508 Soterramento

1900 Suicídio

1304 Surdez

2906 Tombamento da colhedeira

2206 Tombamento da empilhadeira

2606 Tombamento da motoniveladora 


\section{Anexo 3 \\ Classificação da Variável - Descrição dos Acidentes do Trabalho e Doenças do Trabalho}

\section{Tipos de acidentes}

2506 Tombamento da pá/carregadeira

2706 Tombamento da retroescavadeira

0706 Tombamento de automóvel

0805 Tombamento de caminhões ou veículos pesados

3106 Tombamento de guincho

2105 Tombamento de lotação

1005 Tombamento de ônibus ou similar

1105 Tombamento de trator

0604 Tombamento de veículos a motor sem especificação

2806 Tombamento do rolocompressor/compactador

2305 Tombamento do veículo de tração animal

1100 Tratores

0115 Traumatismos ou lesões causados por instrumento de trabalho

0116 Traumatismos ou lesões causados por maquinário agrícola

0117 Traumatismos ou lesões causados por outros tipos de maquinário

0120 Traumatismos ou lesões decorrentes de movimentos (andar, correr...)

0118 Traumatismos ou lesões por maquinário industrial

0119 Traumatismos ou lesões sem especificação

2300 Veiculo de tração animal

2400 Vestuário/calçados 
Anexo 4

Áreas Elaboradas do Estado de São Paulo para o Meio Rural 1997, 1998 e 1999

\begin{tabular}{|c|c|c|c|c|c|}
\hline $\begin{array}{l}\text { Código } \\
\text { IBGE }\end{array}$ & $\begin{array}{c}\text { Municípios do Estado } \\
\text { de São Paulo }\end{array}$ & $\begin{array}{l}\text { Código } \\
\text { IBGE }\end{array}$ & $\begin{array}{c}\text { Municípios do Estado } \\
\text { de São Paulo }\end{array}$ & $\begin{array}{l}\text { Código } \\
\text { IBGE }\end{array}$ & $\begin{array}{c}\text { Municípios do Estado } \\
\text { de Săo Paulo }\end{array}$ \\
\hline & \multicolumn{5}{|c|}{ Área 1} \\
\hline 02507 & Aparecida & 20400 & Ilha Bela & 44301 & Roseira \\
\hline 03158 & Arapeí & 24402 & Jacarei & 45001 & Salesópolis \\
\hline 03505 & Areias & 24907 & Jambeiro & 46009 & Santa Branca \\
\hline 04909 & Bananal & 26308 & Lagoinha & 46801 & Santa Isabel \\
\hline 08504 & Caçapava & 26605 & Lavrinhas & 48203 & Santo Antônio do Pinhal \\
\hline 08603 & Cachoeira Paulista & 27207 & Lorena & 48609 & São Bento do Sapucaí \\
\hline 09700 & Campos do Jordão & 31704 & Monteiro Lobato & 49607 & São José do Barreiro \\
\hline 09957 & Canas & 32306 & Natividade da Serra & 49904 & São José dos Campos \\
\hline 10500 & Caraguatatuba & 35606 & Paraibuna & 50001 & São Luís do Paraitinga \\
\hline 13405 & Cruzeiro & 38006 & Pindamonhangaba & 50704 & São Sebastião \\
\hline 13603 & Cunha & 38501 & Piquete & 52007 & Silveiras \\
\hline 18305 & Guararema & 40754 & Potim & 54102 & Taubaté \\
\hline 18404 & Guaratinguetá & 41901 & Queluz & 54805 & Tremembé \\
\hline 20202 & Igaratá & \multicolumn{3}{|c|}{ Área 2} & Ubatuba \\
\hline 03901 & Arujá & 25508 & Joanópolis & 43303 & Ribeirão Pires \\
\hline 06607 & Biritiba-Mirim & 28502 & Mairiporã & 44103 & Rio Grande da Serra \\
\hline 07100 & Bom Jesus dos Perdð̌es & 29401 & Mauá & 47809 & Santo André \\
\hline 13801 & Diadema & 30607 & Moji das Cruzes & 48708 & São Bernardo do Campo \\
\hline 15707 & Ferraz de Vasconcelos & 32405 & Nazaré Paulista & 50308 & São Paulo \\
\hline 18800 & Guarulhos & 38600 & Piracaia & 52502 & Suzano \\
\hline \multicolumn{5}{|c|}{ Área 3} & Vargem \\
\hline 05401 & Barra do Turvo & 20301 & Iguape & 36208 & Pariquera-Açu \\
\hline 05708 & Barueri & 20426 & Ilha Comprida & 37206 & Pedro de Toledo \\
\hline 06359 & Bertioga & 21200 & Iporanga & 37602 & Peruibe \\
\hline 09007 & Caieiras & 22109 & Itanhaém & 39103 & Pirapora do Bom Jesus \\
\hline 09205 & Cajamar & 22158 & Itaóca & 41000 & Praia Grande \\
\hline 09254 & Cajati & 22208 & Itapecerica da Serra & 42602 & Registro \\
\hline 09908 & Cananéia & 22505 & Itapevi & 42800 & Ribeira \\
\hline 10609 & Carapicuiba & 23305 & Itariri & 43253 & Ribeirão Grande \\
\hline 13009 & Cotia & 24600 & Jacupiranga & 47304 & Santana de Pamaíba \\
\hline 13504 & Cubatão & 25003 & Jandira & 48500 & Santos \\
\hline 14809 & Eldorado & 26100 & Juquiá & 49953 & São Lourenço da Serra \\
\hline 15004 & Embu & 26209 & Juquitiba & 51009 & São Vicente \\
\hline 15103 & Embu-Guaçu & 29906 & Miracatu & 51801 & Sete Barras \\
\hline 16309 & Francisco Morato & 31100 & Mongaguá & 52809 & Taboão da Serra \\
\hline 16408 & Franco da Rocha & 34401 & Osasco & 56453 & Vargem Grande Paulista \\
\hline 18701 & Guarujá & & & & \\
\hline
\end{tabular}


Anexo 4

Áreas Elaboradas do Estado de São Paulo para o Meio Rural 1997, 1998 e 1999

\begin{tabular}{|c|c|c|c|c|c|}
\hline $\begin{array}{l}\text { Código } \\
\text { IBGE }\end{array}$ & $\begin{array}{c}\text { Municípios do Estado } \\
\text { de São Paulo }\end{array}$ & $\begin{array}{l}\text { Código } \\
\text { IBGE }\end{array}$ & $\begin{array}{c}\text { Municípios do Estado } \\
\text { de São Paulo }\end{array}$ & $\begin{array}{c}\text { Código } \\
\text { IBGE }\end{array}$ & $\begin{array}{c}\text { Municípios do Estado } \\
\text { de São Paulo } \\
\end{array}$ \\
\hline \multicolumn{6}{|c|}{ Área 4} \\
\hline 02705 & Apiaí & 21705 & Itaberá & 37909 & Pilar Do Sul \\
\hline 05351 & Barra do Chapéu & 22406 & Itapeva & 43006 & Ribeirão Branco \\
\hline 07159 & Bom Sucesso de Itararé & 22653 & Itapirapuã Paulista & 43501 & Riversul \\
\hline 08009 & Buri & 23206 & Itararé & 50209 & São Miguel Arcanjo \\
\hline 10203 & Capão Bonito & 32827 & Nova Campina & 53500 & Tapiraí \\
\hline 17604 & Guapiara & 37800 & \multicolumn{3}{|l|}{ Área 5 } \\
\hline 01152 & Alumínio & 19709 & Ibiúna & 41653 & Quadra \\
\hline 02754 & Aracariguama & 21002 & Iperó & 45209 & Salto \\
\hline 02903 & Araçoiaba da Serra & 23909 & Itu & 45308 & Salto de Pirapora \\
\hline 07001 & Boituva & 25854 & Jumirim & 50605 & São Roque \\
\hline 10302 & Capela do Alto & 26407 & Laranjal Paulista & 52205 & Sorocaba \\
\hline 11508 & Cerquilho & 28403 & Mairinque & 54003 & Tatuí \\
\hline 11607 & Cesário Lange & 37503 & Pereiras & 54508 & Tietê \\
\hline 12308 & Conchas & 40507 & Porangaba & 54656 & Torre de Pedra \\
\hline 18503 & Guareí & 40606 & \multicolumn{3}{|l|}{ Área 6} \\
\hline 00758 & Alambari & 12605 & Coronel Macedo & 51108 & Sarapuí \\
\hline 02200 & Angatuba & 15400 & Fartura & 51207 & Sarutaiá \\
\hline 03109 & Arandu & 20905 & Ipauçu & 53005 & Taguaí \\
\hline 05005 & Barăo de Antonina & 21804 & Itaí & 53807 & Taquarituba \\
\hline 06300 & Bernardino de Campos & 22307 & Itapetininga & 54201 & Tejupá \\
\hline 06904 & Bofete & 22802 & Itaporanga & 54607 & Timburi \\
\hline 09452 & Campina do Monte Alegre & 35804 & Paranapanema & & \\
\hline \multicolumn{6}{|c|}{ Área 7} \\
\hline 02309 & Anhembi & 30904 & Mombuca & 44004 & Rio das Pedras \\
\hline 03604 & Areiópolis & 36109 & Pardinho & 45159 & Saltinho \\
\hline 07506 & Botucatu & 38709 & Piracicaba & 47007 & Santa Maria da Serra \\
\hline 11706 & Charqueada & 41059 & Pratania & 50100 & São Manuel \\
\hline \multicolumn{6}{|c|}{ Área 8} \\
\hline 01608 & Americana & 19055 & Holambra & 36505 & Paulínia \\
\hline 03802 & Artur Nogueira & 19071 & Hortolândia & 37107 & Pedreira \\
\hline 09502 & Campinas & 20509 & Indaiatuba & 45803 & Santa Bárbara d'Oeste \\
\hline 10401 & Capivari & 24006 & Itupeva & 48005 & Santo Antônio de Posse \\
\hline 12803 & Cosmópolis & 24709 & Jaguariúna & 52403 & Sumaré \\
\hline 14908 & Elias Fausto & 31803 & Monte Mor & 56206 & Valinhos \\
\hline 15152 & Engenheiro Coelho & 33403 & Nova Odessa & 56701 & Vinhedo \\
\hline
\end{tabular}


Áreas Elaboradas do Estado de São Paulo para o Meio Rural 1997, 1998 e 1999

\begin{tabular}{|c|c|c|c|c|c|}
\hline $\begin{array}{l}\text { Código } \\
\text { IBGE }\end{array}$ & $\begin{array}{l}\text { Municípios do Estado } \\
\text { de São Paulo }\end{array}$ & $\begin{array}{l}\text { Código } \\
\text { IBGE }\end{array}$ & $\begin{array}{c}\text { Municípios do Estado } \\
\text { de São Paulo }\end{array}$ & $\begin{array}{l}\text { Código } \\
\text { IBGE }\end{array}$ & $\begin{array}{c}\text { Municípios do Estado } \\
\text { de São Paulo }\end{array}$ \\
\hline \multicolumn{6}{|c|}{ Área 9} \\
\hline 00501 & Águas de Lindóia & 23404 & Itatiba & 32009 & Morungaba \\
\hline 01905 & Amparo & 25201 & Jarinu & 36802 & Pedra Bela \\
\hline 04107 & Atibaia & 25904 & Jundiaí & 38204 & Pinhalzinho \\
\hline 07605 & Braganca Paulista & 27009 & Lindóia & 51603 & Serra Negra \\
\hline 08405 & Cabreúva & 27306 & Louveira & 52106 & Socorro \\
\hline 09601 & Campo Limpo Paulista & 30805 & Moji-Mirim & 54953 & Tuiuti \\
\hline 22604 & Itapira & 31209 & $\begin{array}{c}\text { Monte Alegre do Sul } \\
\text { Área } 10\end{array}$ & 56503 & Várzea Paulista \\
\hline 00303 & Aguaí & 23800 & Itobi & 50803 & São Sebastião da Grama \\
\hline 00402 & Águas da Prata & 30706 & Moji-Guaçu & 56404 & Vargem Grande do Sul \\
\hline 15186 & Espirito Santo do Pinhal & 48104 & \multirow{2}{*}{\multicolumn{3}{|c|}{$\begin{array}{c}\text { Santo Antônio do Jardim } \\
\text { São João da Boa Vista } \\
\text { Área 11 }\end{array}$}} \\
\hline 57303 & Estiva Gerbi & 49102 & & & \\
\hline 08702 & Caconde & 30508 & Mococa & 53302 & Tambaú \\
\hline 10807 & Casa Branca & 47502 & Santa Rita do Passa Quatro & 53609 & Tapiratiba \\
\hline 10906 & Cássia dos Coqueiros & 47908 & Santo Antônio da Alegria & & \\
\hline 13900 & Divinolândia & 49706 & $\begin{array}{c}\text { São José do Rio Pardo } \\
\text { Área } 12\end{array}$ & & \\
\hline 03307 & Araras & 21408 & Iracemápolis & 43907 & Rio Claro \\
\hline 12209 & Conchal & 26704 & Leme & 46702 & Santa Gertrudes \\
\hline \multicolumn{6}{|c|}{ Área 13} \\
\hline 02002 & Analândia & 21101 & Ipeúna & 46207 & Santa Cruz da Conceição \\
\hline 07902 & Brotas & 23602 & Itirapina & 46306 & Santa Cruz das Palmeiras \\
\hline 12704 & Corumbataí & 39301 & Pirassununga & 48906 & São Carlos \\
\hline 13702 & Descalvado & 40705 & $\begin{array}{l}\text { Porto Ferreira } \\
\text { Área } 14\end{array}$ & 54706 & Torrinha \\
\hline 01707 & Américo Brasiliense & 19303 & Ibaté & 46900 & Santa Lúcia \\
\hline 03208 & Araraquara & 32058 & Motuca & 54755 & Trabiju \\
\hline 14304 & Dourado & 42909 & Ribeirão Bonito & 06706 & Boa Esperança do Sul \\
\hline \multicolumn{5}{|c|}{ Área 15} & \\
\hline 07407 & Borborema & 19600 & Ibitinga & 32900 & Nova Europa \\
\hline 14007 & Dobrada & 22703 & Itápolis & 46504 & Santa Ernestina \\
\hline 16853 & Gavião Peixoto & 29302 & Matão & 52700 & Tabatinga \\
\hline \multicolumn{6}{|c|}{ Area 16} \\
\hline 05609 & Barrinha & 18602 & Guariba & 40903 & Pradópolis \\
\hline 10104 & Cândido Rodrigues & 24303 & Jaboticabal & 53708 & Taquaritinga \\
\hline 15608 & Fernando Prestes & 31308 & Monte Alto & & \\
\hline
\end{tabular}


Áreas Elaboradas do Estado de São Paulo para o Meio Rural 1997,1998 e 1999

\begin{tabular}{|c|c|c|c|c|c|}
\hline $\begin{array}{l}\text { Código } \\
\text { IBGE }\end{array}$ & $\begin{array}{c}\text { Municípios do Estado } \\
\text { de São Paulo }\end{array}$ & $\begin{array}{l}\text { Código } \\
\text { IBGE }\end{array}$ & $\begin{array}{c}\text { Municípios do Estado } \\
\text { de São Paulo }\end{array}$ & $\begin{array}{l}\text { Código } \\
\text { IBGE }\end{array}$ & $\begin{array}{c}\text { Municípios do Estado } \\
\text { de São Paulo } \\
\end{array}$ \\
\hline \multicolumn{6}{|c|}{ Area 17} \\
\hline 01004 & Altinópolis & 14601 & Dumont & 47601 & Santa Rosa de Viterbo \\
\hline 07803 & Brodósqui & 27603 & Luís Antônio & 50902 & São Simão \\
\hline 09403 & Cajuru & 43402 & Ribeirão Preto & 51405 & Serra Azul \\
\hline 13108 & Cravinhos & 46256 & $\begin{array}{c}\text { Santa Cruz da Esperança } \\
\text { Área } 18\end{array}$ & 51504 & Serrana \\
\hline 25102 & Jardinópolis & 51702 & Sertãozinho & 53203 & Taiứva \\
\hline 39509 & Pitangueiras & 53104 & Taiaçu & 53658 & Taquaral \\
\hline 40200 & Pontal & & & & \\
\hline \multicolumn{6}{|c|}{ Área 19} \\
\hline 06102 & Bebedouro & 33908 & Olímpia & 54409 & Terra Roxa \\
\hline 09304 & Cajobi & 39004 & Pirangi & 56800 & Viradouro \\
\hline 14957 & Embaúba & 52601 & Tabapuã & 56909 & Vista Alegre do Alto \\
\hline 31506 & Monte Azul Paulista & & & & \\
\hline \multicolumn{6}{|c|}{ Área 20} \\
\hline 00907 & Altair & 17505 & Guapiaçu & 33007 & Nova Granada \\
\hline 05500 & Barretos & 17901 & Guaraci & 34005 & Onda Verde \\
\hline 12001 & Colina & 19808 & Icém & 51900 & Severínia \\
\hline 12100 & Colómbia & 24204 & Jaborandi & 55604 & Uchoa \\
\hline 17406 & Guaíra & & & & \\
\hline \multicolumn{6}{|c|}{ Área 21} \\
\hline 03000 & Aramina & 17703 & Guará & 29708 & Miguelópolis \\
\hline 08207 & Buritizal & 20103 & Igarapava & 37008 & Pedregulho \\
\hline 13207 & Cristais Paulista & 24105 & Ituverava & 43105 & Ribeirão Corrente \\
\hline 16200 & Franca & 25409 & $\begin{array}{l}\text { Jeriquara } \\
\qquad \text { Área } 22\end{array}$ & 43600 & Rifaina \\
\hline 05906 & Batatais & 33601 & Nuporanga & 44905 & Sales Oliveira \\
\hline 21309 & Ipuã & 34302 & Orlândia & 49409 & São Joaquim da Barra \\
\hline 23701 & Itirapuã & 36307 & Patrocínio Paulista & 49508 & São José da Bela Vista \\
\hline 31902 & Morro Agudo & 42701 & $\begin{array}{l}\text { Restinga } \\
\text { Área } 23\end{array}$ & & \\
\hline 00550 & Águas de Santa Bárbara & 14502 & Duartina & 36703 & Pederneiras \\
\hline 00709 & Agudos & 15194 & Espírito Santo do Turvo & 38907 & Pirajuí \\
\hline 03406 & Arealva & 19105 & Iacanga & 39400 & Piratininga \\
\hline 04305 & Avaí & 19253 & Iaras & 41109 & Presidente Alves \\
\hline 04701 & Balbinos & 27504 & Lucianópolis & 42503 & Reginópolis \\
\hline 06003 & Bauru & 28601 & Manduri & 46405 & Santa Cruz do Rio Pardo \\
\hline 07456 & Borebi & 33809 & Oleo & 55505 & Ubirajara \\
\hline 08306 & Cabrália Paulista & 36570 & Paulistânia & & \\
\hline
\end{tabular}

Continua 
Áreas Elaboradas do Estado de São Paulo para o Meio Rural 1997, 1998 e 1999

\begin{tabular}{|c|c|c|c|c|c|}
\hline $\begin{array}{l}\text { Código } \\
\text { IBGE }\end{array}$ & $\begin{array}{c}\text { Municipios do Estado } \\
\text { de São Paulo }\end{array}$ & $\begin{array}{l}\text { Código } \\
\text { IBGE }\end{array}$ & $\begin{array}{c}\text { Municípios do Estado } \\
\text { de São Paulo }\end{array}$ & $\begin{array}{l}\text { Código } \\
\text { IBGE }\end{array}$ & $\begin{array}{l}\text { Municípios do Estado } \\
\text { de Sð̃o Paulo }\end{array}$ \\
\hline \multicolumn{6}{|c|}{ Área 24} \\
\hline 04503 & Avaré & 14106 & Dois Córregos & 25300 & Jaú \\
\hline 05203 & Bariri & 20004 & Igaraçu do Tietê & 26803 & Lençóis Paulista \\
\hline 05302 & Barra Bonita & 22000 & Itaju & 28007 & Macatuba \\
\hline 06805 & Bocaina & 22901 & Itapuí & 29807 & Mineiros do Tietê \\
\hline 07308 & Boracéia & & & & \\
\hline \multicolumn{6}{|c|}{ Área 25} \\
\hline 00204 & Adolfo & 18107 & Guaranta & 40101 & Pongaí \\
\hline 01400 & Álvaro de Carvalho & 21507 & Irapuã & 41604 & Promissão \\
\hline 04404 & Avanhandava & 21903 & Itajobi & 44608 & Sabino \\
\hline 08801 & Cafelândia & 25805 & Júlio Mesquita & 44806 & Sales \\
\hline 17000 & Getulina & 27108 & Lins & 45605 & Santa Adélia \\
\hline 17208 & Guaiçara & 29500 & Mendonça & 55901 & Uru \\
\hline 17307 & \multicolumn{5}{|c|}{ Área 26} \\
\hline 11102 & Catandurva & 30300 & Mirassol & 39608 & Planalto \\
\hline 11201 & Catiguá & 32504 & Neves Paulista & 40804 & Potirendaba \\
\hline 11300 & Cedral & 32702 & Nipoa & 55356 & Ubarana \\
\hline 14924 & Elisiário & 32801 & Nova Aliança & 55703 & Uniåo Paulista \\
\hline 19402 & Ibirá & 33254 & Novais & 56008 & Urupês \\
\hline 24501 & Jaci & 35101 & Palmares Paulista & 57154 & Zacarias \\
\hline 25706 & José Bonifácio & 35705 & Paraíso & & \\
\hline \multicolumn{6}{|c|}{ Área 27} \\
\hline 01202 & Álvares Florence & 28304 & Magda & 39905 & Poloni \\
\hline 01806 & Américo de Campos & 29609 & Meridiano & 40309 & Pontes Gestal \\
\hline 03950 & Aspásia & 29658 & Mesópolis & 40408 & Populina \\
\hline 04800 & Bálsamo & 30003 & Mira Estrela & 44202 & Riolândia \\
\hline 10708 & Cardoso & 30409 & Mirassolândia & 45704 & Santa Albertina \\
\hline 12902 & Cosmorama & 31001 & Monçбes & 46108 & Santa Clara d'Oeste \\
\hline 14205 & Dolcinópolis & 31407 & Monte Aprazível & 47403 & Santa Rita d'Oeste \\
\hline 15202 & Estrela d'Oeste & 32603 & Nhandeara & 49201 & São João das Duas Pontes \\
\hline 15509 & Fernandópolis & 34203 & Orindiúva & 49805 & São José do Rio Preto \\
\hline 15905 & Floreal & 34757 & Ouroeste & 51306 & Sebastianópolis do Sul \\
\hline 18008 & Guarani d'Oeste & 35002 & Palestina & 53401 & Tanabi \\
\hline 20707 & Indiaporã & 35903 & Paranapuã & 55307 & Turmalina \\
\hline 21150 & Ipiguá & 36257 & Parisi & 56107 & Valentim Gentil \\
\hline 28106 & Macaubal & 36604 & Paulo de Faria & 56958 & Vitoria Brasil \\
\hline 28205 & Macedônia & 36901 & Pedranópolis & 57105 & Votuporanga \\
\hline
\end{tabular}

continua 
Áreas Elaboradas do Estado de São Paulo para o Meio Rural 1997, 1998 e 1999

\begin{tabular}{|c|c|c|c|c|c|}
\hline $\begin{array}{l}\text { Código } \\
\text { IBGE }\end{array}$ & $\begin{array}{c}\text { Municípios do Estado } \\
\text { de São Paulo }\end{array}$ & $\begin{array}{l}\text { Código } \\
\text { IBGE }\end{array}$ & $\begin{array}{c}\text { Municípios do Estado } \\
\text { de São Paulo }\end{array}$ & $\begin{array}{l}\text { Código } \\
\text { IBGE }\end{array}$ & $\begin{array}{c}\text { Municípios do Estado } \\
\text { de São Paulo }\end{array}$ \\
\hline \multicolumn{6}{|c|}{ Área 28} \\
\hline 02101 & Andradina & 26506 & Lavínia & 46603 & Santa Fé do Sul \\
\hline 02606 & Aparecida d'Oeste & 29104 & Marinópolis & 47650 & Santa Salete \\
\hline 04206 & Auriflama & 30102 & Mirandópolis & 47205 & Santana da Ponte Pensa \\
\hline 11003 & Castilho & 32108 & Murutinga do Sul & 48054 & Sto Antônio do Aracanguá \\
\hline 13850 & Dirce Reis & 32843 & Nova Canaã Paulista & 49003 & São Francisco \\
\hline 16804 & Gastão Vidigal & 32868 & Nova Castilho & 49250 & São João de Iracema \\
\hline 16903 & General Salgado & 33205 & Nova Independência & 52304 & Sud Mennucci \\
\hline 17802 & Guaracaí & 33304 & Nova Luzitânia & 52551 & Suzanápolis \\
\hline 18909 & Guzolândia & 35200 & Palmeira d'Oeste & 54904 & Três Fronteiras \\
\hline 20442 & Ilha Solteira & 37404 & Pereira Barreto & 55802 & Urânia \\
\hline 23008 & Itapura & 40259 & Pontalinda & & \\
\hline 24808 & Jales & 44509 & $\begin{array}{l}\text { Rubinéia } \\
\text { Área } 29\end{array}$ & & \\
\hline 01103 & Alto Alegre & 08108 & Buritama & 34609 & Osvaldo Cruz \\
\hline 02804 & Aracatuba & 11904 & Clementina & 37305 & Penápolis \\
\hline 05104 & Barbosa & 12506 & Coroados & 37701 & Piacatu \\
\hline 06201 & Bento de Abreu & 16507 & Gabriel Monteiro & 44400 & Rubiácea \\
\hline 06409 & Bilac & 17109 & Glicério & 45100 & Salmourão \\
\hline 06508 & Birigui & 18206 & Guararapes & 48401 & Santópolis do Aguapeí \\
\hline 07704 & Braúna & 27256 & Lourdes & 55208 & Turiúba \\
\hline \multicolumn{6}{|c|}{$\begin{array}{l}\text { Luizaanıa } \\
\text { Área } 30\end{array}$} \\
\hline 00105 & Adamantina & 27405 & Lucélia & 41307 & Presidente Epitácio \\
\hline 00808 & Alfredo Marcondes & 28908 & Mariápolis & 41406 & Presidente Prudente \\
\hline 09106 & Caiuá & 31605 & Monte Castelo & 41505 & Presidente Venceslau \\
\hline 14403 & Dracena & 33106 & Nova Guataporanga & 43238 & Ribeirão dos Indios \\
\hline 15129 & Emilianópolis & 34807 & Ouro Verde & 44707 & Sagres \\
\hline 15806 & Flora Rica & 34906 & Pacaembu & 47106 & Santa Mercedes \\
\hline 16002 & Flórida Paulista & 35408 & Panorama & 48302 & Santo Expedito \\
\hline 20806 & Inúbia Paulista & 36406 & Paulicéia & 49300 & São João do Pau d'Alho \\
\hline 21606 & Irapuru & 38303 & Piquerobi & 55109 & Tupi Paulista \\
\hline 26001 & Junqueiropolis & 40853 & Pracinha & & \\
\hline
\end{tabular}


Áreas Elaboradas do Estado de São Paulo para o Meio Rural 1997,1998 e 1999

\begin{tabular}{|c|c|c|c|c|c|}
\hline $\begin{array}{l}\text { Código } \\
\text { IBGE }\end{array}$ & $\begin{array}{c}\text { Municípios do Estado } \\
\text { de São Paulo }\end{array}$ & $\begin{array}{l}\text { Código } \\
\text { IBGE }\end{array}$ & $\begin{array}{c}\text { Municípios do Estado } \\
\text { de São Paulo }\end{array}$ & $\begin{array}{l}\text { Código } \\
\text { IBGE }\end{array}$ & $\begin{array}{c}\text { Municipios do Estado } \\
\text { de São Paulo }\end{array}$ \\
\hline & \multicolumn{5}{|c|}{ Área 31} \\
\hline 01301 & Álvares Machado & 28700 & Marabá Paulista & 42404 & Regente Feijo \\
\hline 02408 & Anhumas & 29203 & Martinópolis & 43808 & Rinópolis \\
\hline 05807 & Bastos & 30201 & Mirante do Paranapanema & 44251 & Rosana \\
\hline 08900 & Caiabu & 32157 & Nantes & 45506 & Sandovalina \\
\hline 15301 & Estrela do Norte & 32207 & Narandiba & 47700 & Santo Anastácio \\
\hline 15350 & Euclides da Cunha Paulista & 36000 & Parapuã & 52908 & Taciba \\
\hline 19907 & Iepé & 39202 & Pirapozinho & 53906 & Tarabai \\
\hline 20608 & Indiana & 41208 & Presidente Bernardes & 54300 & Teodoro Sampaio \\
\hline 25607 & João Ramalho & 42206 & $\begin{array}{l}\text { Rancharia } \\
\text { Área } 32\end{array}$ & & \\
\hline 03356 & Arco-Iris & 19006 & Herculândia & 39707 & Platina \\
\hline 04008 & Assis & 19204 & Iacri & 40002 & Pompeia \\
\hline 07209 & Borá & 27900 & Lutécia & 41703 & Quatá \\
\hline 10005 & Cândido Mota & 28809 & Maracaí & 41802 & Queiroz \\
\hline 13306 & Cruzália & 34500 & Oscar Bressane & 42008 & Quintana \\
\hline 14700 & Echaporă & 35507 & Paraguacu Paulista & 53955 & Taruma \\
\hline 16101 & Florínia & 37156 & $\begin{array}{c}\text { Pedrinhas Paulista } \\
\text { Área } 33\end{array}$ & 55000 & Tupa \\
\hline 01509 & Alvinlândia & 16705 & Garça & 34708 & Ourinhos \\
\hline 09809 & Campos Novos Paulista & 19501 & Ibirarema & 35309 & Palmital \\
\hline 10153 & Canitar & 27801 & Lupércio & 43204 & Ribeirão do Sul \\
\hline 57204 & Chavantes & 29005 & Marilia & 45407 & Salto Grande \\
\hline 15657 & Fernão & 33700 & Ocauçu & 50506 & Såo Pedro do Turvo \\
\hline 16606 & Gália & 34104 & Oriente & 56602 & Vera Cruz \\
\hline
\end{tabular}


Anexo 5

Áreas Elaboradas do Estado de São Paulo para a Cultura Sucroalcooleira 1997, 1998 e 1999

\begin{tabular}{|c|c|c|c|c|c|}
\hline $\begin{array}{l}\text { Código } \\
\text { IBGE }\end{array}$ & $\begin{array}{c}\text { Municipios do Estado } \\
\text { de São Paulo }\end{array}$ & $\begin{array}{l}\text { Código } \\
\text { IBGE }\end{array}$ & $\begin{array}{c}\text { Municipios do Estado } \\
\text { de São Paulo }\end{array}$ & $\begin{array}{c}\text { Código } \\
\text { IBGE }\end{array}$ & $\begin{array}{c}\text { Municipios do Estado } \\
\text { de São Paulo }\end{array}$ \\
\hline \multicolumn{6}{|c|}{ Área 1} \\
\hline 00303 & Aguaí & 16853 & Gaviåo Peixoto & 38709 & Piracicaba \\
\hline 00501 & Águas de Lindóia & 18503 & Guareí & 38808 & Piraju \\
\hline 01608 & Americana & 18800 & Guarulhos & 40507 & Porangaba \\
\hline 01905 & Amparo & 19055 & Holambra & 40606 & Porto Feliz \\
\hline 02002 & Analândia & 19253 & laras & 41059 & Pratania \\
\hline 02309 & Anhembi & 20202 & Igaratá & 42107 & Rafard \\
\hline 03307 & Araras & 20202 & Igaratá & 42305 & Redenção da Serra \\
\hline 03604 & Areiópolis & 20509 & Indaiatuba & 42800 & Ribeira \\
\hline 03802 & Artur Nogueira & 20905 & Ipaucu & 42909 & Ribeirão Bonito \\
\hline 04503 & Avaré & 21101 & Ipeúna & 43006 & Ribeirão Branco \\
\hline 05005 & Baråo de Antonina & 21408 & Iracemápolis & 43907 & Rio Claro \\
\hline 06300 & Bernardino de Campos & 21705 & Itaberá & 44004 & Rio das Pedras \\
\hline 06706 & Boa Esperança do Sul & 21804 & Itai & 43501 & Riversul \\
\hline 06904 & Bofete & 22307 & Itapetininga & 45001 & Salesópolis \\
\hline 07001 & Boituva & 22406 & Itapeva & 45159 & Saltinho \\
\hline 07456 & Borebi & 22604 & Itapira & 45209 & Salto \\
\hline 07506 & Botucatu & 22802 & Itaporanga & 45803 & Santa Bárbara d'Oeste \\
\hline 07605 & Bragança Paulista & 23206 & Itararé & 46207 & Santa Cruz da Conceição \\
\hline 07902 & Brotas & 23404 & Itatiba & 46405 & Santa Cruz do Rio Pardo \\
\hline 08504 & Cacapava & 23503 & ltatinga & 46702 & Santa Gertrudes \\
\hline 09502 & Campinas & 23602 & Itirapina & 47007 & Santa Maria da Serra \\
\hline 10302 & Capela do Alto & 23800 & Itobi & 48005 & Santo Antônio de Posse \\
\hline 10401 & Capivari & 23909 & Itu & 48104 & Santo Antônio do Jardim \\
\hline 11409 & Cerqueira César & 24709 & Jaguariúna & 48104 & Santo Antônio do Jardim \\
\hline 11508 & Cerquilho & 24907 & Jambeiro & 49102 & São Joåo da Boa Vista \\
\hline 11607 & Cesário Lange & 25201 & Jarinu & 49706 & São José do Rio Pardo \\
\hline 11706 & Charqueada & 26407 & Laranjal Paulista & 49904 & São José dos Campos \\
\hline 57204 & Chavantes & 26803 & Lencois Paulista & 50100 & São Manuel \\
\hline 12209 & Conchal & 26902 & Limeira & 50209 & São Miguel Arcanjo \\
\hline 12308 & Conchas & 28601 & Manduri & 50209 & São Miguel Arcanjo \\
\hline 12407 & Cordeiropolis & 29906 & Miracatu & 50308 & São Paulo \\
\hline 12605 & Coronel Macedo & 30607 & Moji das Cruzes & 50407 & São Pedro \\
\hline 12704 & Corumbataí & 30607 & Moji das Cruzes & 50803 & São Sebastião da Grama \\
\hline 12803 & Cosmópolis & 30706 & Moji-Guaçu & 51603 & Serra Negra \\
\hline 13405 & Cruzeiro & 30805 & Moji-Mirim & 53807 & Taquarituba \\
\hline 13603 & Cunha & 30904 & Mombuca & 53856 & Taquarivai \\
\hline 14106 & Dois Córregos & 31803 & Monte Mor & 54003 & Tatuí \\
\hline 14304 & Dourado & 31704 & Monteiro Lobato & 54201 & Tejupá \\
\hline 14908 & Elias Fausto & 33403 & Nova Odessa & 54508 & Tietê \\
\hline 15152 & Engenheiro Coelho & 33809 & Óleo & 54706 & Torrinha \\
\hline 15186 & Espirito Santo do Pinhal & 35804 & Paranapanema & 54755 & Trabiju \\
\hline 15194 & Espirito Santo do Turvo & 36109 & Pardinho & 55505 & Ubirajara \\
\hline 57303 & Estiva Gerbi & 36208 & Pariquera-Açu & 56404 & Vargem Grande do Sul \\
\hline 15707 & Ferraz de Vasconcelos & 36505 & Paulinia & 56453 & Vargem Grande Paulista \\
\hline 16606 & Gália & 38006 & Pindamonhangaba & & \\
\hline
\end{tabular}


Anexo 5

Áreas Elaboradas do Estado de São Paulo para a Cultura Sucroalcooleira 1997, 1998 e 1999

\begin{tabular}{|c|c|c|c|c|c|c|c|}
\hline $\begin{array}{l}\text { Código } \\
\text { IBGE }\end{array}$ & $\begin{array}{l}\text { Municípios do Estado } \\
\text { de São Paulo }\end{array}$ & \multicolumn{2}{|c|}{$\begin{array}{c}\text { Código } \\
\text { IBGE }\end{array}$} & \multirow{2}{*}{$\begin{array}{c}\begin{array}{c}\text { Municípios do Estado } \\
\text { de São Paulo }\end{array} \\
\text { Área } 2\end{array}$} & \multicolumn{2}{|c|}{$\begin{array}{l}\text { Código } \\
\text { IBGE }\end{array}$} & \multirow[t]{2}{*}{$\begin{array}{c}\text { Municípios do Estado } \\
\text { de São Paulo }\end{array}$} \\
\hline & & & & & & & \\
\hline 01707 & Américo Brasiliense & 19303 & Ibaté & & 40903 & \multicolumn{2}{|c|}{ Pradópolis } \\
\hline 03208 & Araraquara & 19600 & \multicolumn{2}{|c|}{ Ibitinga } & 43709 & \multicolumn{2}{|c|}{ Rincão } \\
\hline 05609 & Barrinha & 22703 & \multicolumn{2}{|c|}{ Itápolis } & 46504 & \multicolumn{2}{|c|}{ Santa Emestina } \\
\hline 07407 & Borborema & 24303 & \multicolumn{2}{|c|}{ Jaboticabal } & 46900 & \multicolumn{2}{|c|}{ Santa Lúcia } \\
\hline 10104 & Cândido Rodrigues & 26704 & \multicolumn{2}{|c|}{ Leme } & 47502 & \multicolumn{2}{|c|}{ Santa Rita do Passa Quatro } \\
\hline 13702 & Descalvado & 29302 & \multicolumn{2}{|c|}{ Matão } & 48906 & \multicolumn{2}{|c|}{ São Carlos } \\
\hline 14007 & Dobrada & 31308 & \multicolumn{2}{|c|}{ Monte Alto } & 52700 & \multicolumn{2}{|c|}{ Tabatinga } \\
\hline 15608 & Fernando Prestes & 32058 & \multicolumn{2}{|c|}{ Motuca } & 53708 & \multicolumn{2}{|c|}{ Taquaritinga } \\
\hline 18602 & Guariba & 32900 & \multicolumn{5}{|c|}{ Nova Europa } \\
\hline 18859 & Guatapará & 39301 & \multicolumn{5}{|c|}{ Pirassununga } \\
\hline \multicolumn{8}{|c|}{ Área 3 } \\
\hline 01004 & Altinópolis & 30508 & \multicolumn{2}{|c|}{ Mococa } & 47908 & \multicolumn{2}{|c|}{ Santo Antônio da Alegria } \\
\hline 07803 & Brodósqui & 39509 & Pitar & iras & 50902 & São & \\
\hline 09403 & Cajuru & 40200 & Pont & & 51405 & Serra & \\
\hline 10807 & Casa Branca & 40705 & Port & rreira & 51504 & Serra & \\
\hline 13108 & Cravinhos & 43402 & Ribe & Preto & 51702 & Sertã & inho \\
\hline 14601 & Dumont & 46256 & Sant & uz da Esperança & 53302 & Taml & \\
\hline 25102 & Jardinópolis & 46306 & Sant & uz das Palmeiras & 53609 & Tapi & \\
\hline 27603 & Luís Antônio & 47601 & Sant & $\begin{array}{l}\text { sa de Viterbo } \\
\text { Área } 4\end{array}$ & & & \\
\hline 00907 & Altair & 20103 & Igar: & & 37008 & Pedr & llho \\
\hline 03000 & Aramina & 21309 & Ipuã & & 39004 & Piran & \\
\hline 05500 & Barretos & 23701 & Itira & & 42701 & Resti & \\
\hline 05906 & Batatais & 24105 & Ituve & & 43105 & Ribe & o Corrente \\
\hline 06102 & Bebedouro & 24204 & Jabo & & 43600 & Rifai & \\
\hline 08207 & Buritizal & 25409 & Jeriq & & 44905 & Sales & liveira \\
\hline 09304 & Cajobi & 25409 & Jeriq & & 49409 & São J & quim da Barra \\
\hline 12001 & Colina & 29708 & Mig & polis & 49508 & São J & é da Bela Vista \\
\hline 12100 & Colômbia & 31506 & Mon & zul Paulista & 51900 & Seve & \\
\hline 13207 & Cristais Paulista & 31902 & Mor & gudo & 52601 & Taba & \\
\hline 14957 & Embaúba & 33007 & Nov & anada & 53104 & Taias & \\
\hline 16200 & Franca & 33601 & Nup & & 53203 & Taiú & \\
\hline 17406 & Guaíra & 33908 & Olín & & 53658 & Taqu & \\
\hline 17505 & Guapiaçu & 34005 & Ond & rde & 54409 & Terra & coxa \\
\hline 17703 & Guará & 34302 & Orlâ & & 55604 & Ucho & \\
\hline 17901 & Guaraci & 35705 & Para & & 56800 & Virac & \\
\hline 19808 & Icém & 36307 & Patro & o Paulista & 56909 & Vista & Jegre do Alto \\
\hline
\end{tabular}


Anexo 5

Áreas Elaboradas do Estado de São Paulo para a Cultura Sucroalcooleira 1997, 1998 e 1999

\begin{tabular}{|c|c|c|c|c|c|}
\hline $\begin{array}{l}\text { Código } \\
\text { IBGE }\end{array}$ & $\begin{array}{c}\text { Municipios do Estado } \\
\text { de Såo Paulo }\end{array}$ & $\begin{array}{l}\text { Código } \\
\text { IBGE }\end{array}$ & $\begin{array}{c}\text { Municípios do Estado } \\
\text { de São Paulo }\end{array}$ & $\begin{array}{l}\text { Código } \\
\text { IBGE }\end{array}$ & $\begin{array}{c}\text { Municípios do Estado } \\
\text { de São Paulo } \\
\end{array}$ \\
\hline & \multicolumn{5}{|c|}{ Área 5} \\
\hline 00204 & Adolfo & 17307 & Guaimbê & 32702 & Nipoã \\
\hline 00709 & Agudos & 18107 & Guarantã & 32801 & Nova Aliança \\
\hline 03406 & Arealva & 19105 & Iacanga & 33254 & Novais \\
\hline 03703 & Ariranha & 19402 & Ibirá & 33502 & Novo Horizonte \\
\hline 04305 & Avaí & 20004 & Igaraçu do Tietê & 35101 & Palmares Paulista \\
\hline 04404 & Avanhandava & 21507 & Irapuã & 36570 & Paulistânia \\
\hline 05104 & Barbosa & 21903 & Itajobi & 36703 & Pederneiras \\
\hline 05203 & Barini & 22000 & Itaju & 37305 & Penápolis \\
\hline 05302 & Barra Bonita & 22901 & Itapuí & 38105 & Pindorama \\
\hline 06003 & Bauru & 24501 & Jaci & 38907 & Pirajuí \\
\hline 06805 & Bocaina & 25300 & Jaú & 39400 & Piratininga \\
\hline 07308 & Boracéia & 25706 & José Bonifácio & 40101 & Pongaí \\
\hline 08306 & Cabrália Paulista & 25805 & Júlio Mesquita & 40804 & Potirendaba \\
\hline 08801 & Cafelândia & 27108 & Lins & 41109 & Presidente Alves \\
\hline 11102 & Catanduva & 27504 & Lucianópolis & 41604 & Promissão \\
\hline 11201 & Catiguá & 28007 & Macatuba & 42503 & Reginópolis \\
\hline 11300 & Cedral & 28858 & Marapoama & 44806 & Sales \\
\hline 14502 & Duartina & 29005 & Marilia & 45605 & Santa Adélia \\
\hline 14924 & Elisiário & 29500 & Mendonça & 49805 & São José do Rio Preto \\
\hline 17000 & Getulina & 29807 & Mineiros do Tietê & 55356 & Ubarana \\
\hline 17208 & Guaiçara & 32504 & $\begin{array}{c}\text { Neves Paulista } \\
\text { Área } 6\end{array}$ & 56008 & Urupês \\
\hline 00105 & Adamantina & 20707 & Indiapora & 39608 & Planalto \\
\hline 00808 & Alfredo Marcondes & 20806 & Inúbia Paulista & 39707 & Platina \\
\hline 01103 & Alto Alegre & 21606 & Irapuru & 39905 & Poloni \\
\hline 01301 & Álvares Machado & 24808 & Jales & 40002 & Pompéia \\
\hline 02101 & Andradina & 25607 & Joðo Ramalho & 40259 & Pontalinda \\
\hline 02408 & Anhumas & 26001 & Junqueirópolis & 40408 & Populina \\
\hline 02606 & Aparecida d'Oeste & 26506 & Lavinia & 40853 & Pracinha \\
\hline 02804 & Araçatuba & 27256 & Lourdes & 41208 & Presidente Bernardes \\
\hline 03950 & Aspásia & 27405 & Lucélia & 41307 & Presidente Epitácio \\
\hline 04008 & Assis & 27702 & Luiziânia & 41406 & Presidente Prudente \\
\hline 04206 & Auriflama & 27900 & Lutécia & 41505 & Presidente Venceslau \\
\hline 04800 & Bálsamo & 28106 & Macaubal & 41703 & Quatá \\
\hline 05807 & Bastos & 28205 & Macedônia & 42206 & Rancharia \\
\hline 06201 & Bento de Abreu & 28304 & Magda & 42404 & Regente Feijó \\
\hline 06409 & Bilac & 28700 & Marabá Paulista & 43204 & Ribeirão do Sul \\
\hline 06508 & Birigui & 28809 & Maracaí & 43238 & Ribeirão dos Indios \\
\hline 07209 & Borá & 28908 & Mariápolis & 43808 & Rinópolis \\
\hline 07704 & Braúna & 29104 & Marinópolis & 44202 & Riolândia \\
\hline 07753 & Brejo Alegre & 29203 & Martinópolis & 44251 & Rosana \\
\hline 08108 & Buritama & 29609 & Meridiano & 44400 & Rubiácea \\
\hline 08900 & Caiabu & 29658 & Mesópolis & 44509 & Rubinéia \\
\hline
\end{tabular}




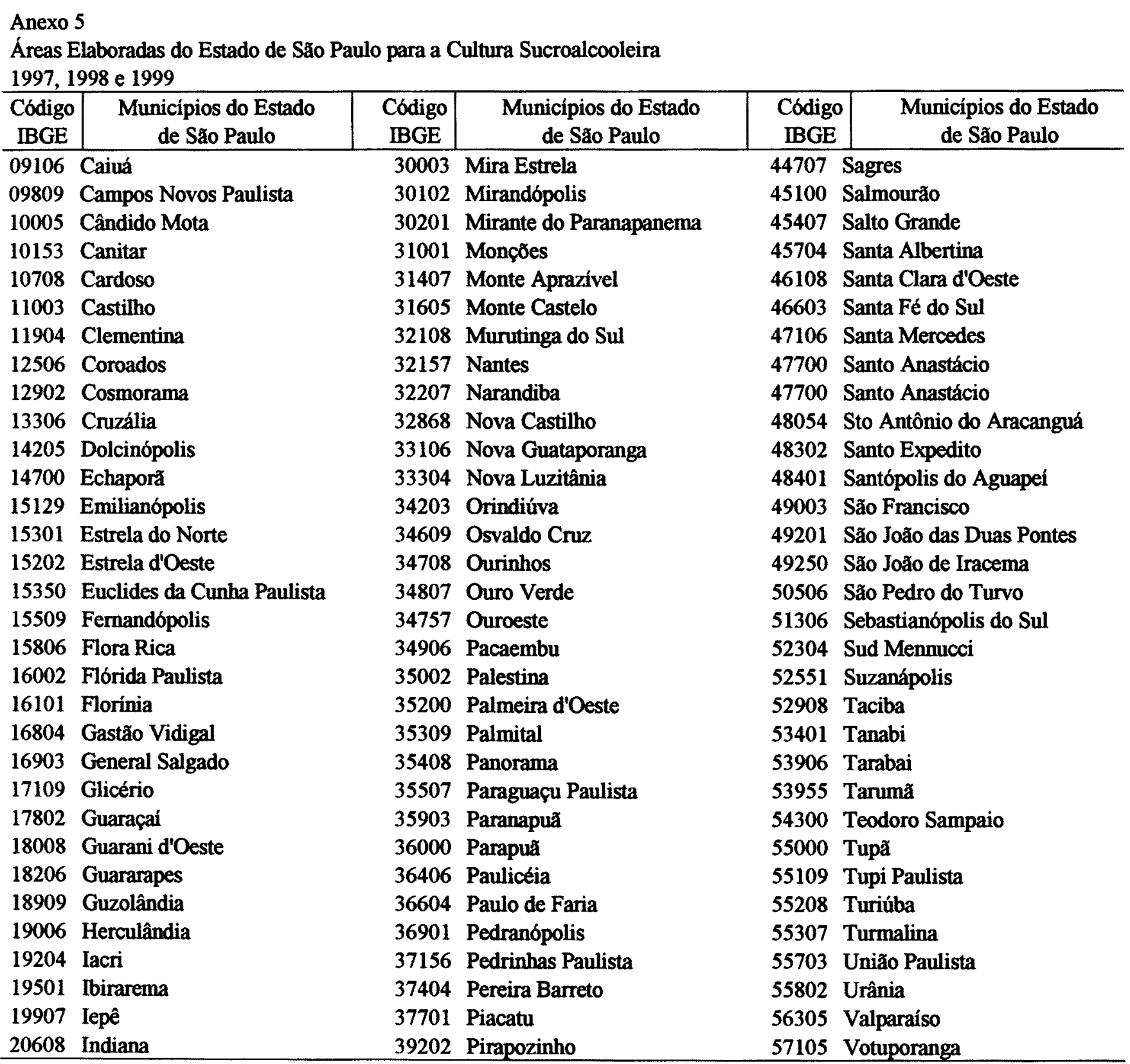


Anexo 6

Áreas Elaboradas do Estado de São Paulo para a Cultura de Frutas Cítricas

1997,1998 e 1999

\begin{tabular}{|c|c|c|c|c|c|}
\hline $\begin{array}{l}\text { Código } \\
\text { IBGE }\end{array}$ & $\begin{array}{c}\text { Áreas Elaboradas } \\
\text { Estado de São Paulo }\end{array}$ & $\begin{array}{l}\text { Código } \\
\text { IBGE }\end{array}$ & $\begin{array}{c}\text { Áreas Elaboradas } \\
\text { Estado de São Paulo }\end{array}$ & $\begin{array}{l}\text { Código } \\
\text { IBGE }\end{array}$ & $\begin{array}{c}\text { Áreas Elaboradas } \\
\text { Estado de São Paulo }\end{array}$ \\
\hline \multicolumn{6}{|c|}{ Área 1} \\
\hline 00303 & Aguaí & 20509 & Indaiatuba & 40705 & Porto Ferreira \\
\hline 00758 & Alambari & 20905 & Ipauçu & 41059 & Pratania \\
\hline 01608 & Americana & 21002 & Iperó & 42107 & Rafard \\
\hline 01905 & Amparo & 21408 & Iracemápolis & 42602 & Registro \\
\hline 02200 & Angatuba & 21705 & Itaberá & 43006 & Ribeirão Branco \\
\hline 03109 & Arandu & 21804 & Itaí & 43253 & Ribeirão Grande \\
\hline 03307 & Araras & 22307 & Itapetininga & 44004 & Rio das Pedras \\
\hline 03604 & Areiópolis & 22406 & Itapeva & 45803 & Santa Bárbara d'Oeste \\
\hline 03802 & Artur Nogueira & 22604 & Itapira & 46207 & Santa Cruz da Conceição \\
\hline 06300 & Bernardino de Campos & 23206 & Itararé & 46306 & Santa Cruz das Palmeiras \\
\hline 06904 & Bofete & 23305 & Itariri & 46702 & Santa Gertrudes \\
\hline 07506 & Botucatu & 23404 & Itatiba & 47007 & Santa Maria da Serra \\
\hline 08009 & Buri & 23503 & Itatinga & 47908 & Santo Antônio da Alegria \\
\hline 08504 & Caçapava & 23800 & Itobi & 48005 & Santo Antônio de Posse \\
\hline 09452 & Campina do Monte Alegre & 24709 & Jaguariúna & 49102 & São João da Boa Vista \\
\hline 09502 & Campinas & 24907 & Jambeiro & 49706 & São José do Rio Pardo \\
\hline 10203 & Capão Bonito & 25201 & Jarinu & 49904 & São José dos Campos \\
\hline 10302 & Capela do Alto & 26308 & Lagoinha & 50001 & São Luís do Paraitinga \\
\hline 10401 & Capivari & 26704 & Leme & 50100 & São Manuel \\
\hline 10807 & Casa Branca & 26902 & Limeira & 50209 & São Miguel Arcanjo \\
\hline 10906 & Cássia dos Coqueiros & 27009 & Lindóia & 50308 & São Paulo \\
\hline 11409 & Cerqueira César & 27207 & Lorena & 50407 & São Pedro \\
\hline 11508 & Cerquilho & 27306 & Louveira & 51108 & Sarapuí \\
\hline 11607 & Cesário Lange & 28403 & Mairinque & 51801 & Sete Barras \\
\hline 11706 & Charqueada & 29906 & Miracatu & 52106 & Socorro \\
\hline 12209 & Conchal & 30508 & Mococa & 52205 & Sorocaba \\
\hline 12308 & Conchas & 30607 & Moji das Cruzes & 53302 & Tambaú \\
\hline 12407 & Cordeirópolis & 30706 & Moji-Guaçu & 53807 & Taquarituba \\
\hline 12605 & Coronel Macedo & 30805 & Moji-Mirim & 53856 & Taquarivaí \\
\hline 13900 & Divinolândia & 30904 & Mombuca & 54003 & Tatui \\
\hline 15152 & Engenheiro Coelho & 35804 & Paranapanema & 54102 & Taubaté \\
\hline 15186 & Espírito Santo do Pinhal & 36208 & Pariquera-Açu & 54201 & Tejupá \\
\hline 57303 & Estiva Gerbi & 36505 & Paulínia & 54706 & Torrinha \\
\hline 18305 & Guararema & 37107 & Pedreira & 56206 & Valinhos \\
\hline 18503 & Guareí & 37909 & Pilar Do Sul & 56354 & Vargem \\
\hline 19055 & Holambra & 38709 & Piracicaba & 56404 & Vargem Grande do Sul \\
\hline 19709 & Ibiúna & 38808 & Piraju & 57006 & Votorantim \\
\hline 20442 & Ilha Solteira & 40606 & Porto Feliz & & \\
\hline
\end{tabular}


Anexo 6

Áreas Elaboradas do Estado de São Paulo para a Cultura de Frutas Cítricas

1997,1998 e 1999

\begin{tabular}{|c|c|c|c|c|c|c|c|}
\hline \multirow[t]{2}{*}{$\begin{array}{c}\text { Código } \\
\text { IBGE }\end{array}$} & \multirow[t]{2}{*}{$\begin{array}{l}\text { Áreas Elaboradas } \\
\text { Estado de São Paulo }\end{array}$} & \multicolumn{2}{|c|}{$\begin{array}{l}\text { Código } \\
\text { IBGE }\end{array}$} & \multirow{2}{*}{$\begin{array}{l}\begin{array}{c}\text { Áreas Elaboradas } \\
\text { Estado de São Paulo }\end{array} \\
\text { Área } 2\end{array}$} & \multicolumn{2}{|c|}{$\begin{array}{c}\text { Código } \\
\text { IBGE }\end{array}$} & \multirow[t]{2}{*}{$\begin{array}{c}\text { Áreas Elaboradas } \\
\text { Estado de São Paulo }\end{array}$} \\
\hline & & & & & & & \\
\hline 01707 & Américo Brasiliense & 16853 & Gavi & ão Peixoto & 42909 & \\
\hline 02002 & Analândia & 18859 & Guat & apará & 43709 & \multicolumn{2}{|c|}{$\begin{array}{l}\text { Ribeirão Bonito } \\
\text { Rincão }\end{array}$} \\
\hline 03208 & Araraquara & 19303 & Ibate & & 43907 & \multicolumn{2}{|c|}{ Rio Claro } \\
\hline 06706 & Boa Esperança do Sul & 19600 & Ibiti & & 46504 & \multicolumn{2}{|c|}{ Santa Emestina } \\
\hline 07407 & Borborema & 22703 & Itápc & & 46900 & \multicolumn{2}{|c|}{ Santa Lúcia } \\
\hline 07902 & Brotas & 23602 & Itira & sina & 47502 & \multicolumn{2}{|c|}{ Santa Rita do Passa Quatro } \\
\hline 12704 & Corumbataí & 29302 & Mat & & 48906 & \multicolumn{2}{|c|}{ São Carlos } \\
\hline 13702 & Descalvado & 32058 & Mot & & 52700 & \multicolumn{2}{|c|}{ Tabatinga } \\
\hline 14007 & Dobrada & 32900 & Nov: & Europa & 54755 & \multicolumn{2}{|c|}{ Trabiju } \\
\hline 14304 & Dourado & 39301 & Pira: & sununga & & & \\
\hline \multicolumn{8}{|c|}{ Área 3} \\
\hline 00907 & Altair & 17901 & Guar & & 40903 & \multicolumn{2}{|c|}{ Pradópolis } \\
\hline 01004 & Altinópolis & 18602 & Gua & & 42701 & \multicolumn{2}{|c|}{ Restinga } \\
\hline 03000 & Aramina & 19808 & Icém & & 43105 & \multicolumn{2}{|c|}{ Ribeirão Corrente } \\
\hline 05500 & Barretos & 20103 & Igar & pava & 43402 & \multicolumn{2}{|c|}{ Ribeirão Preto } \\
\hline 05609 & Barrinha & 21309 & Ipuã & & 44905 & \multicolumn{2}{|c|}{ Sales Oliveira } \\
\hline 05906 & Batatais & 23701 & Itira & & 46256 & \multicolumn{2}{|c|}{ Santa Cruz da Esperança } \\
\hline 06102 & Bebedouro & 24105 & Ituve & rava & 47601 & \multicolumn{2}{|c|}{ Santa Rosa de Viterbo } \\
\hline 07803 & Brodósqui & 24204 & Jabo & andi & 49409 & \multicolumn{2}{|c|}{ São Joaquim da Barra } \\
\hline 08207 & Buritizal & 24303 & Jabo & icabal & 49508 & \multicolumn{2}{|c|}{ São José da Bela Vista } \\
\hline 09304 & Cajobi & 25102 & Jard & nópolis & 50902 & \multicolumn{2}{|c|}{ São Simão } \\
\hline 09403 & Cajuru & 27603 & Luís & Antônio & 51405 & \multicolumn{2}{|c|}{ Serra Azul } \\
\hline 10104 & Cândido Rodrigues & 29708 & Mig & elópolis & 51504 & \multicolumn{2}{|c|}{ Serrana } \\
\hline 12001 & Colina & 31308 & Mon & te Alto & 51702 & Sertã & inho \\
\hline 12100 & Colômbia & 31506 & Mon & te Azul Paulista & 51900 & Sever & \\
\hline 13108 & Cravinhos & 33007 & Nov & Granada & 53104 & Taiaç & \\
\hline 13207 & Cristais Paulista & 33908 & Olín & & 53203 & Taiúv & \\
\hline 14601 & Dumont & 34005 & Ond & Verde & 53658 & Taque & \\
\hline 14957 & Embaúba & 34302 & Orlâ & dia & 53708 & Taque & itinga \\
\hline 15608 & Fernando Prestes & 36307 & Patr & cínio Paulista & 54409 & Terra & oxa \\
\hline 16200 & Franca & 39004 & Pira & & 56800 & Virad & \\
\hline 17406 & Guaíra & 39509 & Pita & gueiras & 56909 & Vista & legre do Alto \\
\hline 17505 & Guapiaçu & 40200 & Pon & & & & \\
\hline
\end{tabular}

Continua 
Anexo 6

Áreas Elaboradas do Estado de São Paulo para a Cultura de Frutas Cítricas 1997,1998 e 1999

\begin{tabular}{|c|c|c|c|c|c|}
\hline $\begin{array}{l}\text { Código } \\
\text { IBGE }\end{array}$ & $\begin{array}{c}\text { Áreas Elaboradas } \\
\text { Estado de São Paulo }\end{array}$ & $\begin{array}{l}\text { Código } \\
\text { IBGE }\end{array}$ & $\begin{array}{c}\text { Áreas Elaboradas } \\
\text { Estado de São Paulo }\end{array}$ & & $\begin{array}{c}\text { Áreas Elaboradas } \\
\text { Estado de São Paulo }\end{array}$ \\
\hline & & & Área 4 & & \\
\hline 00105 & Adamantina & 18909 & Guzolândia & 36000 & Parapuã \\
\hline 00204 & Adolfo & 19105 & lacanga & 36257 & Parisi \\
\hline 00709 & Agudos & 19253 & laras & 36570 & Paulistânia \\
\hline 01202 & Álvares Florence & 19402 & Ibirá & 36604 & Paulo de Faria \\
\hline 01301 & Álvares Machado & 19501 & Ibirarema & 36703 & Pederneiras \\
\hline 01400 & Álvaro de Carvalho & 20004 & Igaraçu do Tietê & 36901 & Pedranópolis \\
\hline 01509 & Alvinlândia & 20707 & Indiaporã & 37305 & Penápolis \\
\hline 01806 & Américo de Campos & 21150 & Ipiguá & 37404 & Pereira Barreto \\
\hline 02101 & Andradina & 21507 & Irapuã & 38105 & Pindorama \\
\hline 02606 & Aparecida d'Oeste & 21903 & Itajobi & 38907 & Pirajuí \\
\hline 03406 & Arealva & 22000 & Itaju & 39400 & Piratininga \\
\hline 03703 & Ariranha & $22901 \mathrm{I}$ & Itapuí & 39608 & Planalto \\
\hline 04008 & Assis & $24501 \mathrm{~J}$ & Jaci & 39905 & Poloni \\
\hline 04206 & Auriflama & $24808 \mathrm{~J}$ & Jales & 40101 & Pongaí \\
\hline 04305 & Avaí & $25300 \mathrm{~J}$ & Jaú & 40259 & Pontalinda \\
\hline 04404 & Avanhandava & 25706 & José Bonifäcio & 40408 & Populina \\
\hline 04503 & Avaré & 25805 & Júlio Mesquita & 40804 & Potirendaba \\
\hline 04602 & Bady Bassitt & 26506 & Lavínia & 41109 & Presidente Alves \\
\hline 04800 & Bálsamo & 26803 & Lençóis Paulista & 41307 & Presidente Epitácio \\
\hline 05104 & Barbosa & 27108 & Lins & 41604 & Promissão \\
\hline 05203 & Bariri & 27504 & Lucianópolis & 41703 & Quatá \\
\hline 05302 & Barra Bonita & 27702 & Luiziânia & 42404 & Regente Feijó \\
\hline 05807 & Bastos & 27801 & Lupércio & 42503 & Reginópolis \\
\hline 06003 & Bauru & 27900 & Lutécia & 44202 & Riolândia \\
\hline 06409 & Bilac & $28007 \mathrm{~N}$ & Macatuba & 44400 & Rubiácea \\
\hline 06805 & Bocaina & $28106 \quad$ & Macaubal & 44509 & Rubinéia \\
\hline 07308 & Boracéia & 28205 & Macedônia & 44608 & Sabino \\
\hline 07456 & Borebi & 28304 & Magda & 44806 & Sales \\
\hline 08108 & Buritama & 28601 & Manduri & 45407 & Salto Grande \\
\hline 08306 & Cabrália Paulista & 28858 & Marapoama & 45605 & Santa Adélia \\
\hline 08801 & Cafelândia & 29005 & Marília & 45704 & Santa Albertina \\
\hline 09809 & Campos Novos Paulista & 29104 & Marinópolis & 46108 & Santa Clara d'Oeste \\
\hline 10005 & Cândido Mota & 29500 & Mendonça & 46405 & Santa Cruz do Rio Pardo \\
\hline 10153 & Canitar & 29609 & Meridiano & 46603 & Santa Fé do Sul \\
\hline 10708 & Cardoso & 29658 & Mesópolis & 47650 & Santa Salete \\
\hline 11102 & Catanduva & 29807 & Mineiros do Tietê & 48054 & Santo Antônio do Aracanguá \\
\hline
\end{tabular}




\section{Anexo 6}

Áreas Elaboradas do Estado de São Paulo para a Cultura de Frutas Cítricas

1997, 1998 e 1999

\begin{tabular}{llllll}
\hline $\begin{array}{c}\text { Código } \\
\text { IBGE }\end{array}$ & \multicolumn{1}{c}{$\begin{array}{c}\text { Áreas Elaboradas } \\
\text { Estado de São Paulo }\end{array}$} & $\begin{array}{c}\text { Código } \\
\text { IBGE }\end{array}$ & $\begin{array}{c}\text { Áreas Elaboradas } \\
\text { Estado de São Paulo }\end{array}$ & $\begin{array}{l}\text { Código } \\
\text { IBGE }\end{array}$ & $\begin{array}{c}\text { Áreas Elaboradas } \\
\text { Estado de São Paulo }\end{array}$ \\
\hline 11201 & Catiguá & 30003 & Mira Estrela & 48401 & Santópolis do Aguapé \\
11300 & Cedral & 30102 & Mirandópolis & 49003 & São Francisco \\
57204 & Chavantes & 30300 & Mirassol & 49201 & São João das Duas Pontes \\
12902 & Cosmorama & 31001 & Monçães & 49805 & São José do Rio Preto \\
13306 & Cruzália & 31407 & Monte Aprazivel & 50506 & São Pedro do Turvo \\
13850 & Dirce Reis & 32157 & Nantes & 51306 & Sebastianópolis do Sul \\
14106 & Dois Córregos & 32504 & Neves Paulista & 52304 & Sud Mennucci \\
14205 & Dolcinópolis & 32603 & Nhandeara & 52551 & Suzanápolis \\
14502 & Duartina & 32702 & Nipoã & 52601 & Tabapuã \\
14924 & Elisiário & 32801 & Nova Aliança & 53401 & Tanabi \\
15194 & Espírito Santo do Turvo & 32868 & Nova Castilho & 54904 & Três Fronteiras \\
15202 & Estrela d'Oeste & 33304 & Nova Luzitânia & 55000 & Tupã \\
15509 & Fernandópolis & 33254 & Novais & 55307 & Turmalina \\
15905 & Floreal & 33502 & Novo Horizonte & 55356 & Ubarana \\
16002 & Flórida Paulista & 33809 & Óleo & 55505 & Ubirajara \\
16606 & Gália & 34203 & Orindiúva & 55604 & Uchoa \\
16705 & Garça & 34609 & Osvaldo Cruz & 55703 & União Paulista \\
16804 & Gastão Vidigal & 34708 & Ourinhos & 55802 & Urânia \\
16903 & General Salgado & 34757 & Ouroeste & 55901 & Uru \\
17000 & Getulina & 35002 & Palestina & 56008 & Urupês \\
17208 & Guaiçara & 35101 & Palmares Paulista & 56107 & Valentim Gentil \\
17307 & Guaimbê & 35200 & Palmeira d'Oeste & 56958 & Vitoria Brasil \\
17802 & Guaraçá & 35507 & Paraguaçu Paulista & 57105 & Votuporanga \\
18008 & Guarani d'Oeste & 35705 & Paraíso & 57154 & Zacarias \\
18107 & Guarantã & 35903 & Paranapuã & & \\
\hline
\end{tabular}




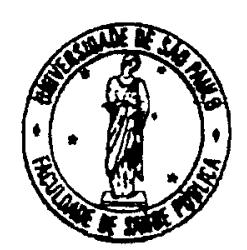

\section{Universidade de São Paulo}

\section{Faculdade de Saúde Pública}

COMITÊ DE ÉTICA-COEP

Av. Dr. Arnaldo, 715 - CEP 01246-904 - São Paulo - Brasil

Telefones: (55-11) 3066-7779 - fone/fax (55-11) 3064-7314-e-mail: mdgracas@usp.br

\section{Of. COEP/013/04}

19 de fevereiro de 2004

Prezada Orientadora,

Pelo presente, informo que o Comitê de Ética em Pesquisa da Faculdade de Saúde Pública da Universidade de São Paulo-COEP, analisou e aprovou com recomendações, em sua 1. $1 / 04$ Sessão Extraordinária, realizada em 19.02.04 de acordo com os requisitos da Resolução 196/96, o protocolo de pesquisa n. ${ }^{\circ} 1087$, intitulado: "OS ACIDENTES DE TRABALHO NO ESTADO DE SÃO PAULO: UMA ANÁLISE DE GÊNERO EM ATIVIDADES RURAIS DAS AGROINDÚSTRIAS SUCRO-ALCOOLEIRA E CÍTRICA, da pesquisadora Rosa Maria Vieira de Freitas.

O Comitê recomenda que a responsável pelo projeto obtenha um termo de concordância dos dirigentes das mesmas para o uso das informações nele contidas, caso não estejam disponibilizadas ao público e, também entregue à essas instituições um termo de responsabilidade assinado por ela de que os dados serão utilizados de acordo com as recomendações da Resolução 196/96.

Atenciosamente,

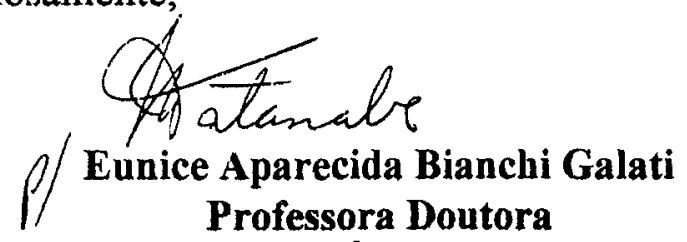

Coordenadora do Comitê de Ética em Pesquisa da FSP-COEP

\section{Ilm. ${ }^{*}$ Sr."}

Prof." Dr. Ana Isabel B. B. Paraguay

Departamento de Saúde Ambiental 


\section{TERMO DE CONCORDÂNCIA}

A Fundação Sistema Estadual de Análise de Dados - Seade responsável pela pesquisa "Acidentes do Trabalho no Estado de São Paulo" financiada pela Fundação Jorge Duprat Figueiredo de Segurança do Trabalho - Fundacentro, elaborada no ano de 2000, disponibiliza as informações contidas em sua base de dados para realização do projeto de mestrado da pesquisadora Rosa Maria Vieira de Freitas no Departamento de Saúde Ambiental da Faculdade de Saúde Pública/USP.

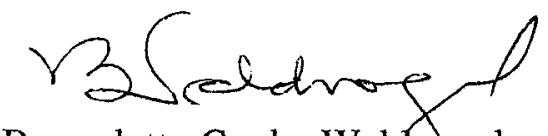

Bernadette Cunha Waldvgel

Gerente de Indicadores e Estudos Populacionais

São Paulo, 02 de março de 2004 


\section{TERMO DE COMPROMISSO DE USO}

Eu, Rosa Maria Vieira de Freitas, comprometo-me a utilizar as informações relativas à pesquisa "Acidentes do Trabalho no Estado de São Paulo", exclusivamente para fins estatísticos em meu trabalho de mestrado junto ao Departamento de Saúde Ambiental da Faculdade de Saúde Pública/USP, conforme as recomendações da Resolução 196/96 do Conselho Nacional de Saúde.

Comprometo-me, também, a citar a Fundação Seadé/Fundacentro como fonte dos dados.

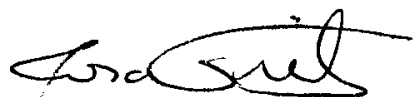

Rosa Maria Vieira de Freitas

São Paulo, 02 de março de 2004 